\title{
FLOOD TOLERANCE OF PLANT SPECIES \\ IN BOTTOMLAND FORESTS OF THE \\ SOUTHEASTERN UNITED STATES
}

\section{BY}

RUSSELL FRANCIS THERIOT

A DISSERTATION PRESENTED TO THE GRADUATE SCHOOL OF THE UNIVERSITY OF FLORIDA IN PARTIAL FULFILLMENT OF THE REQUIREMENTS FOR THE DEGREE OF DOCTOR OF PHILOSOPHY

UNIVERSITY OF FLORIDA 
Digitized by the Internet Archive

in 2011 with funding from

University of Florida, George A. Smathers Libraries with support from LYRASIS and the Sloan Foundation

To my parents 


\section{ACKNOWLEDGMENTS}

This research effort was greatly aided by innumerable people. Foremost among them is Dr. Dana Sanders, who assisted me in all phases of the study. His advice and encouragement throughout this effort are greatly appreciated. I thank Drs. Ken Rodgers, Dan Evans, and Tom Heineke for their assistance in identifying the plant species in this study. Blake Parker was invaluable in helping me interpret the soils in the study. Don Hill conducted the geodetic surveys for all of the sites. Phil Jones and Jeff Irvin taught me all I know about hydrology. Phil was especially helpful in correcting the water surface elevations between the study sites and the gauging stations, and Jeff interpreted the hydrologic program into FORTRAN language. I am also grateful to Dr. Dara Wilber, who assisted me in the statistical analyses of the data .

Many people provided helpful discussion and advice on various aspects of the study, including Drs. Donal Hook, Bill Patrick, Helen Leitman, Sandra Brown, and Bill Mitsch.

I gratefully acknowledge the support and understanding of Dr. Bob Engler, who allowed a work schedule flexible enough to finish the manuscript.

I especially want to thank my wife and children, who encouraged me to go on when it would have been easy to quit. 
Finally, I would like to thank my major professor, Dr. Jerome Shireman, for his advice, encouragement, and support in guiding my degree program, and also my committee for their helpful suggestions and patience. 
LIST OF TABLES . . . . . . . . . . . . . . . . . . . vii

LIST OF FIGURES . . . . . . . . . . . . . . . . . . . . $\mathrm{x}$

ABSTRACT . . . . . . . . . . . . . . . . . . . . . $x i i$

INTRODUCTION . . . . . . . . . . . . . . . . . . . . . . . . . . . . 1

Plant Community Organization . . . . . . . . . . . 2

Bottomland Forest Community Organization . . . . . . . . 3

Zonation of Bottomland Forests . . . . . . . . . . . . 5

Purpose and objectives . . . . . . . . . . . . . . 7

METHODS . . . . . . . . . . . . . . . . . . . 8

Study Area . . . . . . . . . . . . . . . . . . . . 8

Site Selection . . . . . . . . . . . . . 10

Determining Hydrologic Zone Elevations . . . . . . . . . 11

Site Preparation and Data Collection . . . . . . . . . . 14

Analyzing Vegetation Data . . . . . . . . . . . . 16

Calculating Species FTI Numbers . . . . . . . . . . . 17

RESULTS AND DISCUSSION . . . . . . . . . . . . . . . . . 20

Flood Analysis of Study Sites . . . . . . . . . . . . 20

Vegetation Data . . . . . . . . . . . . . . . 22

Weighted Averaging . . . . . . . . . . . . . . . . 36

Statistical Analysis of the Vegetation Data. . . . . . 37

Cluster Analyses . . . . . . . . . . . . . . . . . 38

Discriminant Function Analysis . . . . . . . . . . . . . 47

Regional Variation in Species FTI Numbers . . . . . . . . 56

SUMMARY AND CONCLUSIONS . . . . . . . . . . . . . . 59

APPENDIX A SITE DESCRIPTIONS AND MAP LOCATIONS . . . . . . . 62

APPENDIX B GUIDE FOR COMPUTER PROGRAM FOR ANALYZING
HYDROLOGIC DATA . . . . . . . . . . . . . 90

APPENDIX C HYDROGRAPH FOR STEELE BAYOU (SITE 3) . . . . . . . 97 
APPENDIX D IMPORTANCE VALUES FOR SPECIES BY ZONE AND

VEGETATION LAYER . . . . . . . . . . . . 102

APPENDIX E FTI PLANT LIST AND COMPARISON WITH TWO OTHER

WATER-TOLERANCE RATING SYSTEMS . . . . . . . . . 186

REFERENCES . . . . . . . . . . . . . . . . . . 202

BIOGRAPHICAL SKETCH . . . . . . . . . . . . . . 207 
1 Hydrologic Zones Occurring in Bottomland Forests of the Southeastern United States . . . . . . . . . . . .

2 Annual Flood Frequency (Percent of Years in which Boundary Is Exceeded at Least Once during Growing Season for More than 7 days) for Zone Boundaries . . .

3 Average Annual Duration of Flood Events (days)

for Zone Boundaries . . . . . . . . . . . . . . . . . . .

4 FTI Numbers of Commonly Occurring Species in this Study . . . . . . . . . . . . . . . . . .

5 Variations in Species Flood Tolerance Index Numbers According to Life Stage . . . . . . . . . . . . .

6 Comparison of Three Water-Tolerance Ratings for Selected Bottomland Forest Tree Species . . . . . . . . .

7 Relative Frequencies in Each Hydrologic Zone of Tree Species Used in the Statistical Analyses; Groupings of Species Correspond to Cluster Membership . . . . . .

8 Relative Frequency of Occurrence of Each Sapling Species in the Hydrologic Zones along with Their Cluster Memberships . . . . . . . . . . . . . . .

9 Relative Frequencies in Each Hydrologic Zone of the Vine Species Used in Statistical Analyses . . . . . . . .

10 Mean Importance Values for Species in Each Cluster Used in the DFA, Arranged by Zone/Sample... . . . . . . .

11 Predicted Hydrologic Zones (Columns) and Actual Zones (Rows) Based on DFA Results Using Only Tree Importance Values . . . . . . . . . . . . . . . .

12 Predicted Hydrologic Zones (Columns) and Actual Zones (Rows) Based on DFA Results Using Average FTI Values for A11 Observed Tree Species at the Site. . 
13 Cross-Validation Results of Zone Membership Using Linear Discriminant Function Analysis . . . . . . . . . .

D-1 Importance Values for Species Occurring at Site 1 , Arranged by Zone and Vegetation Layer . . . . . . . . . .

D-2 Importance Values for Species Occurring at Site 2, Arranged by Zone and Vegetation Layer . . . . . . . . .

D-3 Importance Values for Species Occurring at Site 3, Arranged by Zone and Vegetation Layer . . . . . . . . .

D-4 Importance Values for Species Occurring at Site 4, Arranged by Zone and Vegetation Layer . . . . . . . .

D-5 Importance Values for Species Occurring at Site 5, Arranged by Zone and Vegetation Layer . . . . . . . . .

D-6 Importance Values for Species Occurring at Site 6 , Arranged by Zone and Vegetation Layer . . . . . . . . . .

D-7 Importance Values for Species Occurring at Site 7 , Arranged by Zone and Vegetation Layer . . . . . . . . . .

D-8 Importance Values for Species Occurring at Site 8, Arranged by Zone and Vegetation Layer . . . . . . . . .

D-9 Importance Values for Species Occurring at Site 9, Arranged by Zone and Vegetation Layer . . . . . . . . . .

D-10 Importance Values for Species Occurring at Site 10, Arranged by Zone and Vegetation Layer . . . . . . . . . .

D-11 Importance Values for Species Occurring at Site 11, Arranged by Zone and Vegetation Layer . . . . . . . . . .

D-12 Importance Values for Species Occurring at Site 12, Arranged by Zone and Vegetation Layer . . . . . . . . .

D-13 Importance Values for Species Occurring at Site 13, Arranged by Zone and Vegetation Layer . . . . . . . . .

D-14 Importance Values for Species Occurring at Site 14, Arranged by Zone and Vegetation Layer . . . . . . . . . .

D-15 Importance Values for Species Occurring at Site 15, Arranged by Zone and Vegetation Layer . . . . . . . . . . 
D-16 Importance Values for Species Occurring at Site 16 , Arranged by Zone and Vegetation Layer . . . . . . . . . .

D-17 Importance Values for Species Occurring at Site 17, Arranged by Zone and Vegetation Layer . . . . . . . . . .

E-1 FTI Plant List 


\section{LIST OF FIGURES}

\section{$\underline{\text { Figure }}$}

1 Zonal classification of bottomland forest wetlands (adapted from Clark and Benforado 1981) . . . . . . . .

2 Study area and sites in the southeastern United States.

3 Representation of a typical research site . . . . . . .

4 Ecological amplitude of some commonly occurring species;

CAAQ: Carya aquatica; FOAC: Forestiera acuminata; FRPE: Fraxinus pennsylvanica; LIST: Liquidambar styraciflua;

NYAQ: Nyssa aquatica; PITA: Pinus taeda; QUAL: Quercus alba; QULY: Quercus Iyrata; SAAL: Sassafras albidum; QUNI: Quercus nigra; TADI: Taxodium distichum; ULAM: Ulmus americana

5 Cluster diagram for trees. . . . . . . . . . . . .

6 Cluster diagram for saplings and shrubs. . . . . . . . . 42

7 Cluster diagram for saplings alone . . . . . . . . . 43

8 Cluster diagram for shrubs alone . . . . . . . . . . 44

9 Cluster diagram for vines . . . . . . . . . . . 46

10 Cluster diagram for herbs . . . . . . . . . . . 48

11 Mean tree FTI numbers plotted versus observed and predicted hydrologic zones for all 55 sites . . . . . . .

A-1 Neches River (sites 1 and 2) . . . . . . . . . . . 64

A-2 Steele Bayou (site 3) . . . . . . . . . . . . . . 66

A-3 Ouachita River (sites 4 and 5) . . . . . . . . . 68

A-4 Yazoo River (site 6) . . . . . . . . . . . . . 70

A-5 Big Black River (site 7) . . . . . . . . . . . 72

A-6 L'Anguille River (sites 8 and 9) . . . . . . . . . . 74 
A-7 Pearl River (site 10) . . . . . . . . . . . . 76

A-8 Apalachicola River (site 11) . . . . . . . . . . . 78

A-9 Apalachicola River (site 12) . . . . . . . . . . 79

A-10 Ocmulgee River (site 13) . . . . . . . . . . . . . 81

A-11 Altamaha River (site 14) . . . . . . . . . . . 83

A-12 Edisto River (site 15) . . . . . . . . . . . . 85

A-13 Lynches River (site 16) . . . . . . . . . . . . 87

A-14 Waccamaw River (site 17) . . . . . . . . . . . 89

B-1 Program logic for computation of days saturated.... . 95

C-1 Hydrograph for Steele Bayou (site 3); the shaded areas represent the nongrowing season, a: 1961-1965, b: 1966-1970, c: 1971-1975, d: 1976-1980....... 


\section{Abstract of Dissertation Presented to the Graduate School of the University of Florida in Partial Fulfillment of the Requirements for the Degree of Doctor of Philosophy \\ FLOOD TOLERANCE OF PLANT SPECIES IN BOTTOMLAND FORESTS OF THE SOUTHEASTERN UNITED STATES}

By

Russel1 Francis Theriot May 1992

Chairman: Jerome V. Shireman

Major Department: School of Forest Resources and Conservation

Vegetation data on species composition along a hydrologic gradient were collected at 17 bottomland forest sites throughout the southeastern United States. Weighted averages based on importance values calculated from 55 stands resulted in flood tolerance index (FTI) numbers, the optimum position for each species along the defined hydrologic gradient, for 312 identified species.

Commonly occurring species were evaluated using cluster analyses and discriminant function analyses. Data on tree, sapling, and vine species clustered into distinct groups, with tree species being the most reliable; however, shrubs and herbaceous species did not cluster distinctly. Discriminant function analysis using FTI numbers for tree species proved to be 82 percent reliable in predicting zones.

The accuracy of the Flood Tolerance Index (FTI) numbers did not vary regionally in the southeastern United States. Therefore, a single 
FTI number calculated for each species can be used to predict hydrologic zones for the entire study area. 


\section{INTRODUCTION}

Bottomland forests are found in the floodplains of rivers in the southeastern United States from eastern Texas to Virginia. They have distinct topographic features that are the result of historical hydrologic characteristics of the rivers, including periodic fluctuations in water levels and changes in stream course. Recognizable floodplain topographic features include first bottoms, second bottoms or terraces, uplands, riverfront, swamp, poorly drained flats, well-drained flats, and sloughs (Putnam, Furnival, and McKnight 1960). These features are characterized by different hydrologic regimes and can be identified as a hydrologic gradient transitional between permanent water and terrestrial uplands .

Many studies have previously described the forest communities associated with these floodplain features (Putnam, Furnival, and McKnight 1960; Broadfoot and Williston 1973; Chambless and Nixon 1975; Hodges and Switzer 1979; Mohler 1979; and Hupp and Osterkamp 1985). However, studies describing the relationship between plant species distribution and specific inundation/saturation regimes in bottomland forests are rare (Bedinger 1971; Mohler 1979; Huffman 1980; and Leitman, Sohm, and Franklin 1984). Even so, these studies all demonstrated that frequency and duration of inundation/saturation exert a controlling influence on the composition, structure, and distribution of wetland plant communities. As an example, Bedinger (1971) found a definite 
relationship between the distribution of plant species and the frequency and duration of flooding in the lower White River Valley, Arkansas. Using flood frequency and duration, he defined four species associations on the White River floodplain, each of which had a distinctly different tolerance to inundation. He concluded that based on plant speciesflooding relationships, plant communities could be used as a basis to transfer flooding parameters to ungauged streams.

\section{Plant Community Organization}

The concept of community structure has been debated for decades. Clements (1916) first described communities as discrete, self-organizing entities that could be considered as discrete organisms. Gleason (1917) disagreed with Clements' organismal concept and proposed a hypothesis relating to the individualistic occurrence of plants. His hypothesis has developed into the continuum concept, which indicates that plant species distribution is determined by the species' response to its environment. Whittaker (1967) and McIntosh (1980) later developed Gleason's ideas, expanding on the continuum concept. They maintain that since plant species adapt differently, no two occupy the same zone. This results in a continuun of overlapping species associations, each responding to subtly different environmental factors (e.g., water, soil $\mathrm{pH}$, nutrients, and solar radiation). A continuum can be described for each factor in various increments or zones.

Zonation simply describes the different levels of an environmental gradient to which a species is responding. The reason zonation is so obvious in some ecosystems is that environmental gradients are 
"ecologically" steep and groups of species have fairly similar tolerance that tend to group them on these gradients (Mitsch and Gosselink 1986). Gleason's individualistic hypothesis can be supported by several studies (Curtis and McIntosh 1951; Brown and Curtis 1952; Bray 1956; Whittaker 1956; Curtis 1959; Whittaker and Niering 1965; and Mohler 1979). These studies show that although species have different ecological amplitudes and, in fact, do not occupy the same niche, they organize as units based on similar ecological conditions. Moreover, intergrades caused by interspecific competition occur between defined types of plant associations. These intergrades can be attributed to continuous environmental variability in time or space or to environmental modification.

\section{Bottomland Forest Community Organization}

Van Der Valk (1981) developed a qualitative model of succession in freshwater wetlands based on the "individualistic" approach to vegetation proposed by Gleason. He based his approach on three key life history features of plant species: life-span, propagule longevity, and propagule establishment requirements. These features are all directly affected by the flooding on bottomland forests.

Brinson (1990), in discussing the "power line" designation for a wetland classification developed by Kangas (1990), considered the power and frequency of inundation as the way in which flood events organize the plant communities in riverine forests. He characterized the flood events as high, medium, and low power events with flood power and frequency of inundation being inversely proportional. High power flood events have a low frequency and determine patterns of the large floodplains features (e.g., oxbow lakes, relict levees, and low ridges and 
swales) that persist for hundreds to thousands of years. Medium power flood events, which occur at an intermediate frequency, affect ecosystem structures that exist from decades to hundreds of years. He identified tree species associations as an ecosystem component likely to be influenced at this scale. The low power, high-frequency flood events occcur annually and affect short-term patterns such as seed germination and seedling survival. His characterization emphasized the dramatic impact flooding has on the regeneration of vegetation in bottomland forests.

Grubb (1977) stated that scientists have failed to understand adequately how plant communities maintain themselves because of a failure to account for the phenomenon of regeneration in plant communities. Huenneke and Sharitz (1986), in a study of microsite abundance and distribution of woody seedlings in a South Carolina cypress-tupelo swamp, concluded that the availability and nature of microsites may affect the distribution and composition of the seedling and sapling strata, thus differentiating the "regeneration niche" described by Grubb.

Although plant species association is determined by a number of interacting environmental factors, it is generally agreed that flooding is the dominant environmental factor at work in bottomland forests, affecting regeneration and life under saturated soil conditions. Flooding persisting for more than a few days will prevent the replenishment of soil oxygen once the soil microbes and plant roots consume the available soil oxygen in the root zone during respiration. Only those plant species that have evolved a mechanism for living in reducing (anaerobic) soil conditions will survive such conditions. In most instances, recurring flooding provides a competitive advantage for plant species that are adapted to saturated and reduced soils. 
Chemistry of wet soils (Pearsall and Mortimer 1939; Patrick and Mikkelsen 1971; Ponnamperuma 1972; Patrick and Delaune 1976; and Faulkner et a1. 1991), and the various physiological effects on vegetation under reducing conditions are well documented (Cannon and Free 1920; Conway 1940; Dubinina 1961; Hosner and Boyce 1962; Hook and Brown 1973; Hook and Scholtens 1978; Vester 1972; and Hook and Crawford 1980).

\section{Zonation of Bottomland Forests}

The hydrologic gradient in bottomland forests ranges from zones of nearly continuous inundation/saturation in deep swamps to infrequent inundation/saturation events for brief periods on upland sites. Because different species respond to different timing and duration of inundation, a strong correlation exists between the distribution of a species and its associated hydrologic and soil-moisture conditions (Hosner and Boyce 1962; Dickson, Hosner, and Hosley 1965; Bedinger 1971, 1978; Larson et a1. 1981; Best, Segal, and Wolfe 1990; and Faulkner et al. 1991). The National Wetlands Technical Council (NWTC) proposed the zonal classification of floodplain forests (Clark and Benforado 1981). The classification system defined six hydrologic zones based on frequency and duration of inundation and soil saturation (Figure 1) and provides the basis for testing in this study.

Larson et a1. (1981) summarized the works of others on the occurrence of plant species in the Gulf Coastal Plain from 238 belt transects in Texas, Louisiana, Arkansas, Mississippi, Alabama, and Florida according to their maximum tolerance to soil-moisture or hydrologic regimes. Larson and his cohorts developed a list of 79 tree and shrub species associated with one or more of the NWTC hydrologic zones. However, the 


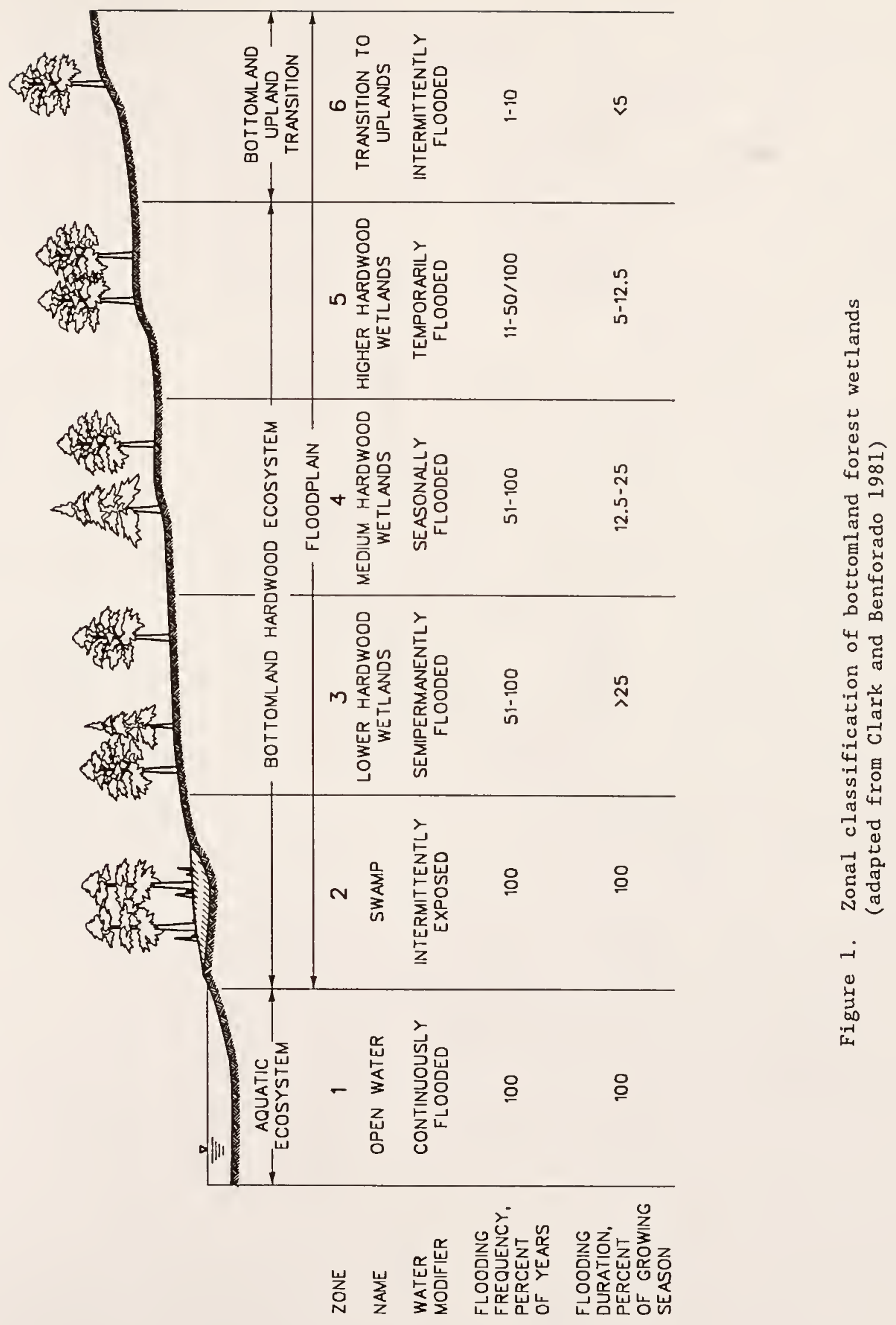


list identifies only presence or absence of a species in a zone and does not identify the ecological amplitude or optimum position of each species along the hydrologic gradient.

\section{Purpose and Objectives}

The purpose of the study was to develop flood tolerance index (FTI) numbers that refect the optimum position for plant species occurring along the hydrologic gradient in bottomland forests of the southeastern United States. The resulting FTI numbers can then be used to estimate the hydrologic regimes of similar ungauged areas using vegetation. Specific objectives were to develop methods for translating recorded hydrologic data into hydrologic zone elevations for southeastern bottomland forests, calculate weighted averages of plant species based on dominance, and determine methods for applying FTI numbers to species occurring in bottomland forests of the southeastern United States. 
METHODS

\section{Study Area}

The study was conducted in portions of the subtropical ecoregion of the southeastern United States (Bailey 1980), including portions of eastern Texas and the Gulf and South Atlantic states. Northern limits of the area extended across northern Arkansas, Mississippi, Alabama, Georgia, and South Carolina. The study area included the states of Louisiana, Arkansas, Mississippi, and Alabama. Georgia and South Carolina were included, except for the piedmont region. Only the extreme eastern portion of Texas was included, as was the northern portion of Florida (Figure 2). The intent was to study natural undisturbed sites encompassing the largest possible area where the resulting FTI numbers would be applicable without including areas that would introduce too many additional species or different climatic variables.

Specific sites were selected according to the following criteria: (1) No major disturbance (e.g., timber harvesting, ditching, or diking) had occurred during the past 20 years; (2) sufficient hydrologic data (10 to 20 years of daily stream gauge readings) accurately portraying water-level fluctuations on the site (considering ponding, tributary influence between site and gauge, etc.) were available; (3) no site changes (e.g., timber harvesting or ditching) were anticipated during the study period; (4) soil data (e.g., soil surveys, soil series, and/or 


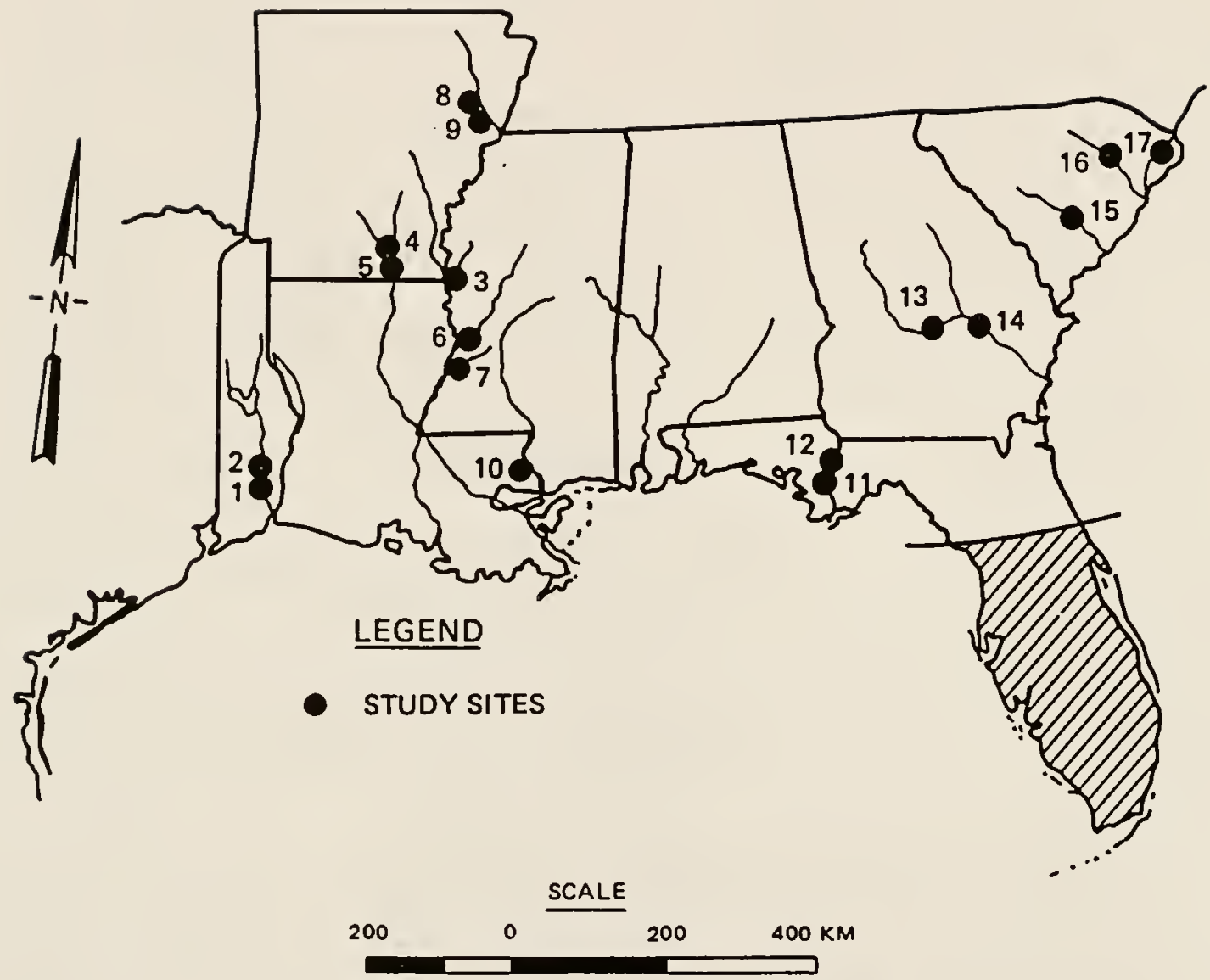

Figure 2. Study area and sites in the southeastern United States 
soil phases, texture, and permeability coefficients) were available; and (5) plant communities were characteristic (e.g., plant communities with few rarely occurring species) of the study area.

\section{Site Selection}

Several hundred potential sites were considered, but most were eliminated because of insufficient stream gauge data. More than 50 sites were visited, but only 17 (Figure 2) satisfied all site criteria and were used in the study. Although all 17 sites met the selection criteria, not all hydrologic zones in each site were suitable for study. Some zones were too narrow and others had been disturbed recently by agricultural or silvicultural practices.

Sites 1 and 2 were located in the Neches River basin in southeastern Texas. The Steele Bayou, Yazoo River, and Big Black River basins in Mississippi, respectively, were designated sites 3,6 , and 7 . Sites 4 and 5 were located in the Ouachita River and sites 8 and 9 in the L'Anguille River basins in Arkansas. Site 10 was located in the Pearl River basin in Louisiana, and sites 11 and 12 in the Apalachicola River basin in Florida. Sites 13 and 14 were located in Georgia in the Ocmulgee River and Altamaha River basins, respectively. Sites 15, 16 , and 17 were located in South Carolina in the Edisto, Lynches, and Waccamaw River basins, respectively.

All sites were characterized by a growing season of greater than 200 days and average annual rainfall ranging from 105 to $170 \mathrm{~cm}$. The overstory typically ranged from cypress-tupelo or willow in depressions and low flats to white oak-hickory or pine on the high ridges. Intermediate areas included overcup oak-bitter pecan, green ash, willow oak, 
and American elm overstory communities. The herbaceous understory was typically dense with diverse species of trees and shrubs, vines, and herbs. Appendix A includes a general description of each study site.

\section{Determining Hydrologic Zone Elevations}

Hydrologic data for each site were obtained either from the U.S. Geological Survey (flow data) or from the local Corps of Engineers District (stage or flow data). Data were analyzed using a FORTRAN computer program developed for determining hydrologic zone elevations in study sites where flooding occurred. The program output is the duration of inundation plus soil saturation of each hydrologic zone boundary, expressed as flow rate or stage data. Table 1 presents inundation/ saturation frequency and duration for Zones 2 to 6.

Hydrologic zone elevations for each site were computed using the most recent 10 to 20 years of daily stream gauge data. When gauge data were provided as daily discharges (flow rate), a rating table (relationship between stage and discharge) was obtained to determine the corresponding stages (elevation).

Plant species show little or no adverse effects from flooding in the winter (dormant) season (Hall and Smith 1955; Bruckner, Bowersox, and Ward 1973). Therefore, hydrology during the dormant season was not used in this study to determine zones.

The dates of the first and last day of the growing season for each site were provided as input to the computer program. Growing season for this study was defined as the period between the last average occurrence of $32^{\circ} \mathrm{F}$ in the spring and the first average occurrence of $32^{\circ} \mathrm{F}$ in the fall. The program eliminated all nongrowing season data and ranked the 
Table 1

Hydrologic Zones Occurring in Bottomland Forests

of the Southeastern United States

\begin{tabular}{|c|c|c|c|}
\hline Zone & Name & $\begin{array}{c}\text { Typical } \\
\text { Inundation/Saturation Frequency }\end{array}$ & $\begin{array}{l}\text { Duration } \\
\text { (percent) }\end{array}$ \\
\hline 2 & $\begin{array}{l}\text { Semipermanently to } \\
\text { permanently inun- } \\
\text { dated or saturated }\end{array}$ & $\begin{array}{l}\text { Annual ( } 1 \text { year frequency) } \\
90 \text { to } 100 \text { years } / 100 \text { years }\end{array}$ & $>75-100$ \\
\hline 3 & $\begin{array}{l}\text { Regularly inun- } \\
\text { dated or saturated }\end{array}$ & $\begin{array}{l}51 \text { to } 90 \text { years } / 100 \text { years } \\
(>1 \text {-year to } 2 \text {-year frequency) }\end{array}$ & $>25-75$ \\
\hline 4 & $\begin{array}{l}\text { Seasonally inun- } \\
\text { dated or saturated }\end{array}$ & $\begin{array}{l}51 \text { to } 90 \text { years } / 100 \text { years } \\
(>1 \text {-year to } 2 \text {-year frequency) }\end{array}$ & $>12.5-25$ \\
\hline 5 & $\begin{array}{l}\text { Irregularly inun- } \\
\text { dated or saturated }\end{array}$ & $\begin{array}{l}11 \text { to } 50 \text { years } / 100 \text { years (well } \\
\text { drained) ( }>10 \text { years }-2 \text {-year } \\
\frac{\text { frequency) }}{1 \text { to } 10 \text { years } / 100 \text { years (poor } 1 y} \\
\text { drained) ( } 100 \text { years, } 10 \text {-year } \\
\text { frequency) }\end{array}$ & $\geq 5-12.5$ \\
\hline 6 & $\begin{array}{l}\text { Intermittently } \\
\text { inundated or } \\
\text { saturated }\end{array}$ & $\begin{array}{l}1 \text { to } 10 \text { years } / 100 \text { years } \\
\text { (100 years, } 10 \text {-year frequency) }\end{array}$ & $<5$ \\
\hline
\end{tabular}

Source: Adapted from Larson et al. (1981).

Although typical inundation/saturation frequencies are provided for each zone, almost any frequency could be associated with any duration of inundation/saturation. Therefore, only duration of inundation/soil saturation was used to determine hydrologic zones.

b Duration based on the growing season.

remaining daily readings during the period of record from highest to lowest flow (or stage). Elevations corresponding to the $75,25,12.5$, and 5 percent durations of inundation were computed. Because the resulting elevations did not include the period during which the soils remain saturated after a period of inundation, saturation effects were integrated. A general description of the soil series occurring in each zone of the study site was obtained from Soil Conservation Service (SCS) 
county soil surveys. An estimated range of permeabilities for the top $30 \mathrm{~cm}$ of the soil profile (i.e., defined for this study as the effective root zone) was determined. This range approximated the period required for the root zone to become saturated after inundation. The slowest value in the range of permeabilities was used to determine the minimun duration of inundation required to saturate the soil. A second range of soil permeabilities between the $30-\mathrm{cm}$ and $90-\mathrm{cm}$ depth was determined. The slowest permeability value of the soil profile between 30 and $90 \mathrm{~cm}$ was used to estimate the time required for draining of the root zone after dewatering. A mean daily transpiration factor for floodplain forests of $5.6 \mathrm{~mm}$ (Brown 1981) also was incorporated for computing desaturation.

Permeability and transpiration coefficients were provided as program input, and new flow (or stage) values for hydrologic zone boundaries were derived that reflected both inundation and soil saturation. This iterative process required a computer search. The computer program added the days of saturation to the days of inundation, and the output was flow (or stage) values that represented the estimated boundary of each hydrologic zone, based on inundation and saturation. The gauge elevation was added to the stage for each zone to obtain the mean sea level elevation at the gauge. When the site was not immediately adjacent to the gauging station, the change in water surface elevation between the study area and the gauging station was determined using the best available water surface profile data. Appendix B explains how the computer program analyzes the hydrology data to produce zone boundaries. 


\section{Site Preparation and Data Collection}

A temporary benchmark was established at each of the 17 sites by surveying from a permanent benchmark. A reconnaissance of the area was conducted for suitable sites, and mean sea level elevations for each hydrologic zone boundary were surveyed along the topographic gradient. The contours of each hydrologic zone boundary within the site were marked with surveyor flags. Fifty-five hydrologic zones were established on the 17 study sites. Sampling methods were adapted from methods described by Whittaker (1973), except where noted.

Sample plots were established parallel to the hydrologic zone boundary (Figure 3). Plots were positioned on the downslope side of the boundary with at least a 5-m buffer between the sample plots and the upper and lower boundary of the hydrologic zone. A belt transect (20 m wide by $40 \mathrm{~m}$ long) containing 10 sample subplots ( $8 \mathrm{~m}$ by $10 \mathrm{~m}$ ) was established within each zone.

Small soil pits in each sample plot were dug with a tile spade to a depth necessary to identify the soil series. In all cases a county soil survey was used to identify the mapped soil series, and information was obtained to verify the soil series on site. Assistance from the local SCS office was used to determine the correct soil series and soil permeability coefficients for each zone sampling site.

Vegetation was sampled by vegetative layer. All trees in each sample plot were identified by species and the diameter at breast height $(1.5 \mathrm{~m})$ of individuals having a diameter of greater than or equal to $7.5 \mathrm{~cm}$ was measured and recorded to the nearest whole centimeter. 
$\otimes B M$
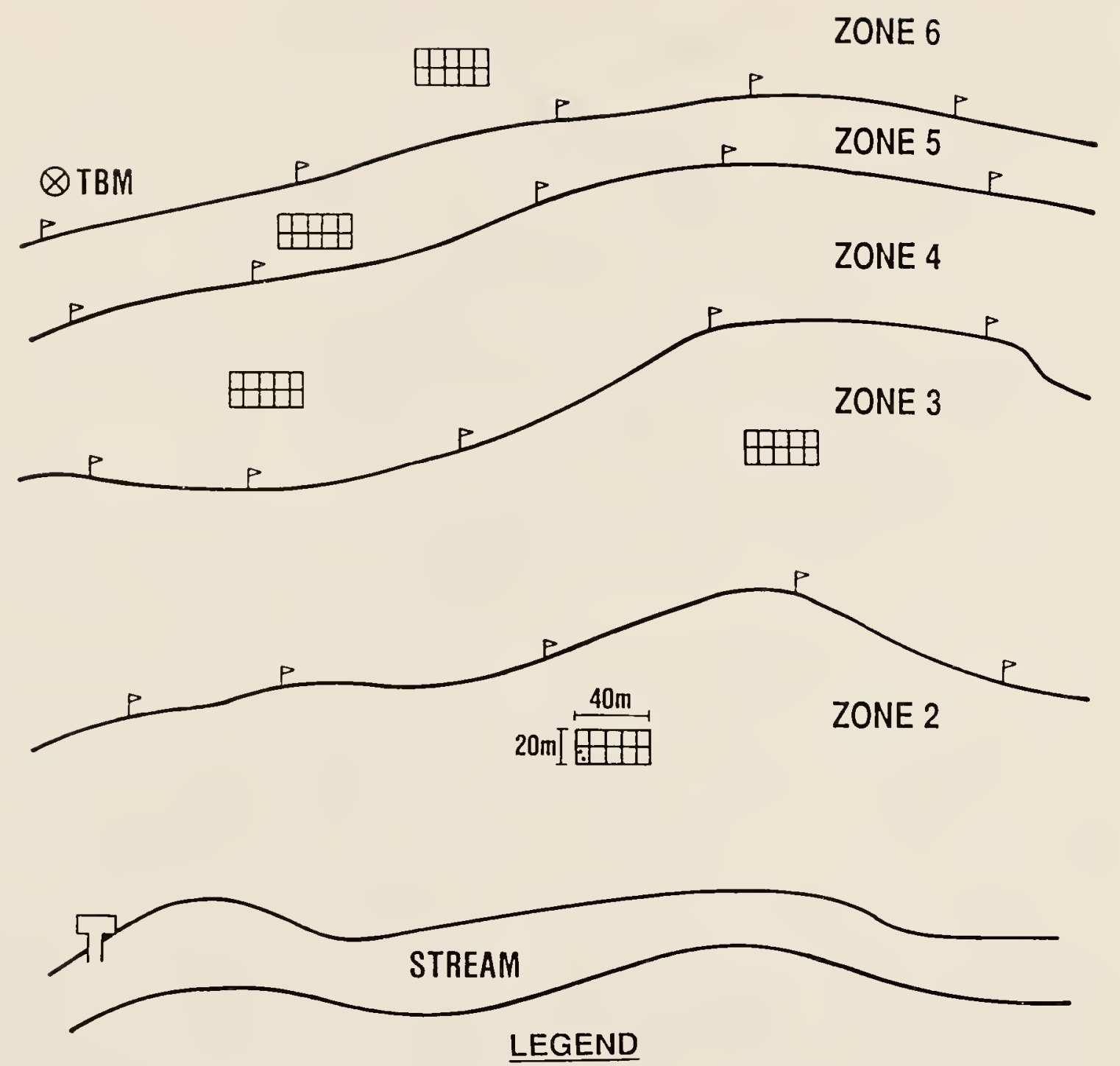

QBM BENCHMARK

$P$ SURVEYED CONTOUR LINE

QTBM TEMPORARY BENCHMARK

$\boxplus$ SAMPLE PLOTS

7 HYDROLOGY GAUGE

Figure 3. Representation of a typical research site 
All saplings and shrubs (woody plants less than $7.5 \mathrm{~cm}$ in diameter, but greater than $1.0 \mathrm{~m}$ in height, excluding vines) in each sample plot were identified by species, and the height class of each individual was recorded. Saplings or shrubs with more than one stem clustered from a single root system were counted as individuals only when separation occurred at or below ground level. The following height classes were used: Class $1=1.0$ to $2.0 \mathrm{~m}$, Class $2=2.1$ to $3.0 \mathrm{~m}$, Class $3=3.1$ to $4.0 \mathrm{~m}$, Class $4=4.1$ to $5.0 \mathrm{~m}$, and Class $5=>5.0 \mathrm{~m}$.

All climbing woody vines greater than $1.0 \mathrm{~m}$ in height in each sample plot were identified by species, the stems of each species counted, and the height class of the highest individual on each tree or sapling/shrub recorded. The following height classes were used:

Class $1=1.0$ to $3.0 \mathrm{~m}$, Class $2=3.1$ to $6.0 \mathrm{~m}$, Class $3=6.1$ to $12.0 \mathrm{~m}$, and Class $4=>12.0 \mathrm{~m}$. Vines were recorded when any portion of the plant occurred in, or overhung, the plot. Individual stems were recorded when separation from the root system occurred at or below ground level.

Percent cover was estimated for each species of herb and woody seedling (greater than $1.0 \mathrm{~m}$ in height) rooted in the plot in two randomly located $1.0-\mathrm{m}^{2}$ quadrats in each subplot using the Daubenmire (1968) cover class method.

\section{Analyzing Vegetation Data}

Importance values for species in all vegetation layers except the herbaceous layer were calculated by adding values for relative density, relative frequency, and relative dominance. Importance values for herbaceous species were calculated by summing relative frequency and 
relative dominance. Importance values were used to determine the FTI number for each species.

When species could not be positively identified in the field, voucher specimens were collected and later identified. Species nomenclature was determined using the National List of Scientific Plant Names (U.S. Department of Agriculture 1982).

\section{Calculating Species FTI Numbers}

Changes in composition of biotic communities along environmental gradients can be addressed with several statistical techniques, the most notable being gradient analysis (Whittaker 1978). Gradient analysis can take several different forms depending on the objective of the analysis. Inferring environmental values (e.g., hydrologic zones) from vegetative species composition is called a "calibration problem" by Ter Braak and Prentice (1988) and is the appropriate approach for this study.

One method of calibration is to use weighted averaging (WA) to estimate environmental factors at sites based on species optima. If a species exhibits a unimodal distribution with respect to an environmental variable, its occurrence is concentrated around the peak of this function (Ter Braak and Prentice 1988). Species with similar optima will naturally tend to occur together. Therefore, an intuitive estimate of the environmental factor of a site is the average of the optima for the species present. The FTI numbers represent weighted averages of species occurrance.

Two additional statistical methods of calibrating an environment (hydrologic zone) with vegetation, recommended by Ter Braak and Prentice 
(1988), are cluster analysis and discriminant function analysis. These two methods were applied to test the reliability of the FTI numbers.

FTI numbers were calculated for each species occurring in each vegetation layer. A species could have three different FTI numbers at a given site, depending on its growth form. For example, Quercus nigra would have three different FTI numbers when present on a site as a tree, sapling, and seedling. Species FTI numbers for each site were computed by the following formula:

$$
\mathrm{FTI}_{i}=\frac{\Sigma_{j}\left(j \cdot I V_{i j}\right)}{\Sigma_{j} I V_{i j}}
$$

where

$$
\begin{aligned}
i & =\text { the } i^{\text {th }} \text { species } \\
j^{a} & =2.5,3.5 \ldots 6.5 \text { (hydrologic zone) } \\
I V_{i j} & =\text { importance value for species } i \text { in the hydrologic zone } j
\end{aligned}
$$
After species FTI numbers were computed for all species in all sites, the average FTI number ( $\overline{\text { FTI }}$ ) for each species across all sites was calculated using the following formula:

$$
\overline{\operatorname{FTI}}_{i}=\frac{\Sigma_{j=i}^{n_{i}} \text { FTI }_{i f}}{n_{1}}
$$

a Because vegetation was sampled between zone boundaries, midrange zone numbers (e.g., 2.5 for Zone 2, 3.5 for Zone 3, etc.) for zones were used in calculating FTI numbers. 
where

$$
\begin{aligned}
i & =\text { the } i^{\text {th }} \text { species } \\
j & =\text { sites } 1 \text { to } 17 \\
\text { FTI }_{i j} & =\text { FTI number of species } i \text { at site } j \\
n_{i} & =\text { number of sites at which species } i \text { occurred }
\end{aligned}
$$




\section{RESULTS AND DISCUSSION}

\section{Flood Analysis of Study Sites}

Twenty years of hydrologic data were used for all sites except sites 4, 5, and 14. Sites 4 and 5 had a 19 -year hydrologic record, and site 14 had a 12 -year record. Calculations of change in water surface elevation between the gauging station and site was necessary for sites $1,2,3,5,9,12$, and 17. Al1 other sites were adjacent to the gauging station and did not require adjustments. Hydrologic analyses of sites 11 and 12 at the Apalachicola River were verified using information from another study (Leitman, Sohm, and Franklin 1984).

The hydrologic records for all sites were analyzed by season for five-year increments. In all cases, variation in flow through time was determined to be within normal seasonal and annual fluctuations. Therefore, it was assumed that the hydrologic record reflected normal conditions (i.e., no major drainage projects during the period of record had significantly impacted the plant community structure).

The hydrologic data also were analyzed to determine annual flood frequency and duration for each site. The boundaries between Zones 2 and 3 and between Zones 3 and 4 are flooded virtually every year (Table 2). The boundary between Zones 4 and 5 is flooded at least every other year, and the boundary between Zones 5 and 6 is flooded from once 
Table 2

Annual Flood Frequency (Percent of Years in which Boundary

Is Exceeded at Least Once during Growing Season for More

than 7 days) for Zone Boundaries

\begin{tabular}{|c|c|c|c|c|}
\hline \multirow[b]{2}{*}{ Site } & \multicolumn{4}{|c|}{ Zone Boundaries } \\
\hline & $2-3$ & $\underline{3-4}$ & $4-5$ & $\underline{5-6}$ \\
\hline 1 & 100 & 90 & 70 & 10 \\
\hline 2 & 100 & 90 & 70 & 10 \\
\hline 3 & 100 & 100 & 85 & 25 \\
\hline 4 & 100 & 94 & 61 & 20 \\
\hline 5 & 100 & 85 & 55 & 20 \\
\hline 6 & 100 & 96 & 77 & 20 \\
\hline 7 & 100 & 100 & 92 & 75 \\
\hline 8 & 100 & 100 & 96 & 60 \\
\hline 9 & 100 & 100 & 96 & 65 \\
\hline 10 & 100 & 100 & 83 & 70 \\
\hline 11 & 100 & 100 & 95 & 70 \\
\hline 12 & 100 & 100 & 95 & 70 \\
\hline 13 & 100 & 100 & 90 & 65 \\
\hline 14 & 100 & 100 & 92 & 67 \\
\hline 15 & 100 & 90 & 85 & 55 \\
\hline 16 & 100 & 100 & 100 & 70 \\
\hline 17 & 100 & 100 & 90 & 70 \\
\hline
\end{tabular}


in 20 years to 3 out of every 4 years. Similar findings were reported by Clark and Benforado (1981) and Roelle et al. (1987).

In general, the average duration of a flood event by site ranged from 3 months to longer than 5 months for the Zone $2-3$ boundary, from 3 weeks to greater than 2 months for the Zone $3-4$ boundary, from 1 week to 1 month for the Zone 4-5 boundary, and from less than 1 day to 10 days for the Zone 5-6 boundary (Table 3 ).

As an example, a hydrograph of site 3 at Steele Bayou (Appendix C) for 20 years of data shows that flooding conditions vary greatly from one season to another and from one year to another. Also, flooding during the growing season usually occurs during early spring and is usually continuous with the nongrowing season flooding. Flooding rarely occurs late in the growing season. Unusual events such as the 1973 flood can greatly affect the calculated value of average events. For example, if the data for 1973 were excluded, the average duration per flood event at site 3 is reduced to 37 days, 25 days, 9 days and less than 1 day, from 143, 30, 14, and 6 days, for Zone boundaries 2 through 5, respectively (Table 4). Such an event has an especially large effect on average duration even over a 20-year period, especially in the higher zones.

\section{Vegetation Data}

Vegetation data were collected at each of the 55 hydrologically defined zones for the 17 study sites (Appendix D). Eleven stands were sampled in Zone 2, 15 stands in Zone 3, 14 stands in Zone 4, 4 stands in Zone 5, and 11 stands in Zone 6. The total possible number of stands 
Table 3

Average Annual Duration of Flood Events (days) for Zone Boundaries

\begin{tabular}{|c|c|c|c|c|}
\hline \multirow[b]{2}{*}{ Site } & \multicolumn{4}{|c|}{ Zone Boundaries } \\
\hline & $2-3$ & $3-4$ & $4-5$ & $5-6$ \\
\hline 1 & 119 & 21 & 12 & $<1$ \\
\hline 2 & 119 & 21 & 12 & $<1$ \\
\hline 3 & 143 & 30 & 14 & 6 \\
\hline 4 & 92 & 41 & 19 & 7 \\
\hline 5 & 93 & 51 & 24 & 8 \\
\hline 6 & 152 & 44 & 22 & 9 \\
\hline 7 & 153 & 50 & 25 & 10 \\
\hline 8 & 139 & 20 & 15 & $<1$ \\
\hline 9 & 139 & 20 & 15 & $<1$ \\
\hline 10 & 141 & 32 & 14 & 3 \\
\hline 11 & 143 & 20 & 16 & 8 \\
\hline 12 & 143 & 20 & 18 & 6 \\
\hline 13 & 162 & 29 & 15 & 8 \\
\hline 14 & 159 & 53 & 24 & 5 \\
\hline 15 & 162 & 52 & 25 & 9 \\
\hline 16 & 174 & 58 & 8 & $<1$ \\
\hline 17 & 198 & 66 & 31 & 10 \\
\hline $\begin{array}{c}\text { Study Area } \\
\text { Average }\end{array}$ & $143 \pm 26$ & $37 \pm 18$ & $18 \pm 6$ & $6 \pm 3$ \\
\hline
\end{tabular}


that could have been sampled for each zone was 17 . Some zones were unsuitable for analysis due to disturbance or because they were too narrow to support sampling areas (Appendix A). Zone 5 was especially susceptible to disturbance. In some cases Zone 5 was cleared because it was dry enough to be farmed during the growing season. In other cases, Zone 5 was too narrow because it was located near the toe of a slope. Therefore, Zone 5 was sampled only at sites $3,11,12$, and 14 .

FTI numbers were calculated for 74 tree species, 118 species of saplings and shrubs, 31 species of woody vines, and 268 species of herbs and woody seedlings, representing 312 different plant species. Because some species occurred in more than one vegetative layer, the total number of species FTI numbers exceeded the total plant species identified.

Appendix E contains a listing by stratum of the plant species identified in this study and the calculated FTI numbers with standard deviations provided for each species.

FTI numbers were calculated for all plants identified by species in this study, regardless of how frequently they occurred in the study. The FTI numbers calculated for species with few occurrences may be suspect. FTI numbers for some of the more commonly occurring species in the study are listed in Table 4. These species can generally be found along the moisture gradient in any bottomland hardwood forest in the southeastern United States in roughly the order from wettest to driest community as presented. Some species, such as Nuttall's oak, are common in only part of the region, and not all species can be expected on the same site due to the species' response to other environmental gradients. 
Table 4

FTI Numbers of Species Commonly Occurring in Bottomland Forests

\begin{tabular}{|c|c|c|}
\hline $\begin{array}{c}\text { Scientific } \\
\text { Name }\end{array}$ & $\begin{array}{c}\text { Common } \\
\text { Name } \\
\end{array}$ & $\begin{array}{c}\text { FTI } \\
\text { Number }\end{array}$ \\
\hline \multicolumn{3}{|c|}{ Trees } \\
\hline Nyssa aquatica & Water tupelo & 2.62 \\
\hline Salix nigra & Black willow & 2.83 \\
\hline Fraxinus caroliniana & Pop-ash & 2.87 \\
\hline Taxodium distichum & Bald cypress & 2.97 \\
\hline Planera aquatica & Water elm & 3.12 \\
\hline Acer drummondii & Drummond red maple & 3.48 \\
\hline Forestiera acuminata & Swamp privet & 3.48 \\
\hline Gleditsia aquatica & Water locust & 3.50 \\
\hline Carya aquatica & Water hickory & 3.54 \\
\hline Quercus 1yrata & Overcup oak & 3.73 \\
\hline Quercus laurifolia & Laurel oak & 3.89 \\
\hline Betula nigra & River birch & 4.01 \\
\hline Acer rubrum & Red maple & 4.21 \\
\hline Ilex decidua & Possumhaw holly & 4.35 \\
\hline Fraxinus pennsylvanica & Green ash & 4.44 \\
\hline Ulmus americana & American elm & 4.46 \\
\hline Quercus nuttallii & Nuttall's oak & 4.50 \\
\hline Quercus phellos & Willow oak & 4.81 \\
\hline Acer negundo & Box elder & 4.83 \\
\hline Celtis laevigata & Sugarberry & 4.84 \\
\hline Carpinus caroliniana & American hornbeam & 4.84 \\
\hline
\end{tabular}


Table 4--continued

\begin{tabular}{|c|c|c|}
\hline $\begin{array}{c}\text { Scientific } \\
\text { Name }\end{array}$ & $\begin{array}{l}\text { Common } \\
\text { Name }\end{array}$ & $\begin{array}{c}\text { FTI } \\
\text { Number }\end{array}$ \\
\hline Liquidambar styraciflua & Sweetgum & 5.03 \\
\hline Platanus occidentalis & Sycamore & 5.18 \\
\hline Nyssa sylvatica & Black gum & 5.27 \\
\hline Carya illinoensis & Pecan & 5.57 \\
\hline Quercus nigra & Water oak & 5.73 \\
\hline Morus rubra & Red mulberry & 5.75 \\
\hline Ilex opaca & American holly & 5.79 \\
\hline Ulmus alata & Winged elm & 6.43 \\
\hline Pinus taeda & Loblolly pine & 6.41 \\
\hline Quercus alba & White oak & 6.50 \\
\hline Sassafras albidum & Sassafras & 6.50 \\
\hline Fagus grandifolia & American Beech & 6.50 \\
\hline Cornus florida & Flowering dogwood & 6.50 \\
\hline Ostrya virginiana & American hophornbeam & 6.50 \\
\hline Quercus stellata & Post oak & 6.50 \\
\hline Quercus falcata & Southern red oak & 6.50 \\
\hline Carya tomentosa & Mockernut hickory & 6.50 \\
\hline \multicolumn{3}{|c|}{$\underline{\text { Saplings and Shrubs }}$} \\
\hline Salix nigra & Black willow & 2.83 \\
\hline Itea virginica & Virginia willow & 2.83 \\
\hline Planera aquatica & Water elm & 3.01 \\
\hline Cephalanthus occidentalis & Buttonbush & 3.13 \\
\hline Styrax americana & Snowbe11 & 3.41 \\
\hline
\end{tabular}


Table 4--continued

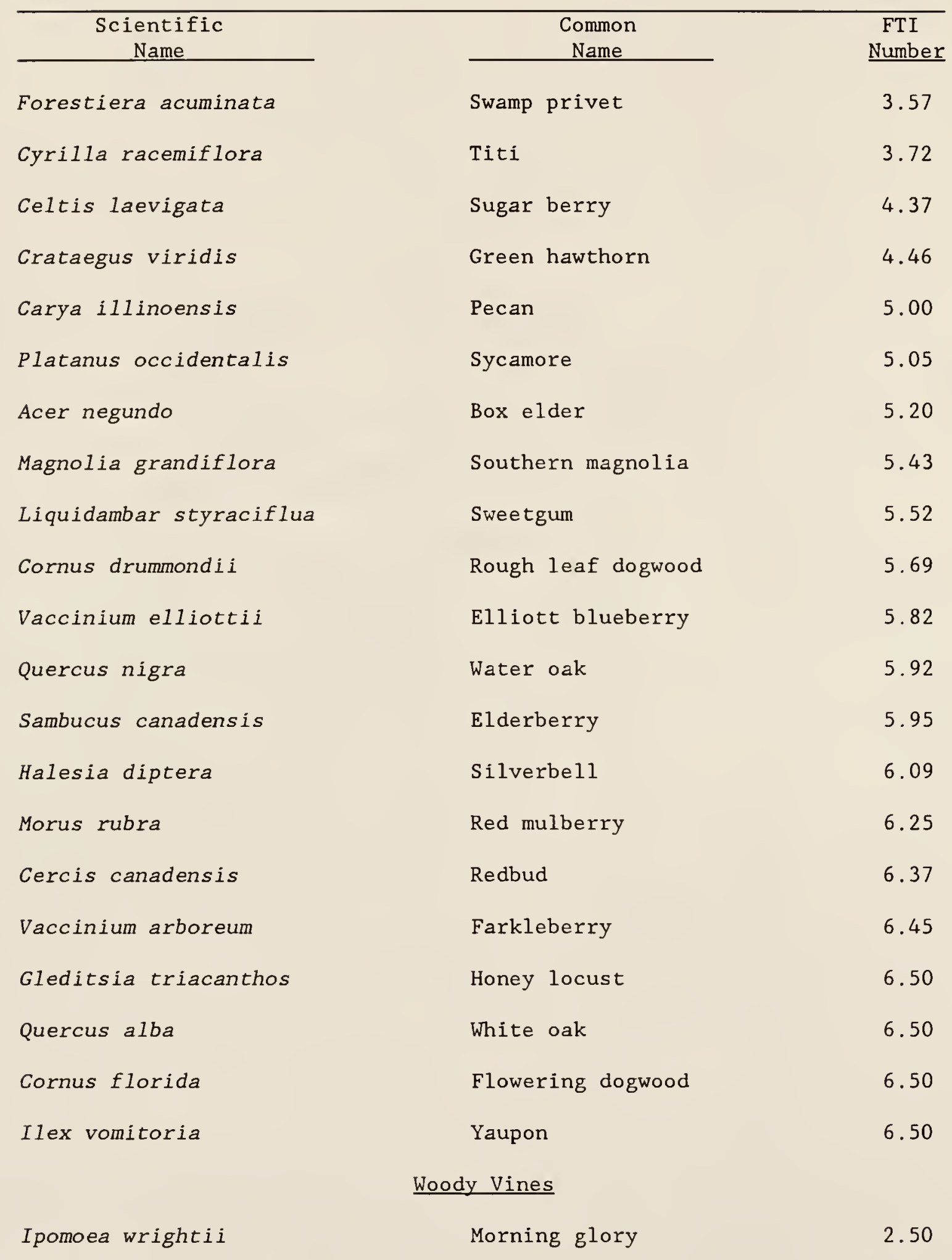


Table 4 - continued

\begin{tabular}{|c|c|c|}
\hline $\begin{array}{c}\text { Scientific } \\
\text { Name }\end{array}$ & $\begin{array}{l}\text { Common } \\
\text { Name }\end{array}$ & $\begin{array}{c}\text { FTI } \\
\text { Number }\end{array}$ \\
\hline Smilax walteri & Walter's greenbriar & 3.05 \\
\hline Brunnichia cirrhosa & Ladies' eardrops & 3.58 \\
\hline Amplelopsis arborea & Peppervine & 3.94 \\
\hline Campsis radicans & Trumpet creeper & 4.05 \\
\hline Vitis palmata & Cat grape & 4.07 \\
\hline Trachelospermum difforme & Star jasmine & 4.18 \\
\hline Vitis riparia & Riverbank grape & 4.27 \\
\hline Smilax laurifolia & Bamboo-vine & 4.33 \\
\hline Cocculus carolinus & Carolina moonseed & 4.37 \\
\hline Berchemia scandens & Rattan vine & 4.55 \\
\hline Similax bona-nox & Saw greenbriar & 4.75 \\
\hline Toxicodendron radicans & Poison ivy & 4.82 \\
\hline Smilax rotundifolia & Common greenbriar & 5.18 \\
\hline Vitis rotundifolia & Muscadine grape & 5.71 \\
\hline Parthenocissus quinquefolia & Virginia creeper & 5.93 \\
\hline Lonicera japonica & Japanese honeysuckle & 6.50 \\
\hline Geisimium sempervirens & Carolina jessamine & 6.50 \\
\hline \multicolumn{3}{|c|}{$\underline{\text { Herbs }}$} \\
\hline Ludwigia decurrens & Primrose-willow & 2.50 \\
\hline Rorippa islandica & Yellowcress & 2.50 \\
\hline Echinodorus cordifolius & Creeping burhead & 3.00 \\
\hline Aster simplex & Lowland white aster & 3.04 \\
\hline Boehmeria cylindrica & Small-spike falsenettle & 3.34 \\
\hline
\end{tabular}


Table 4--continued

\begin{tabular}{|c|c|c|}
\hline $\begin{array}{c}\text { Scientific } \\
\text { Name }\end{array}$ & $\begin{array}{c}\text { Common } \\
\text { Name }\end{array}$ & $\begin{array}{c}\text { FTI } \\
\text { Number } \\
\end{array}$ \\
\hline Spermacoce glabra & Smooth buttonweed & 3.50 \\
\hline Saururus cernuus & Lizard-tail & 3.65 \\
\hline Leersia lenticularis & Catchfly grass & 3.67 \\
\hline Justicia ovata & Waterwillow & 3.83 \\
\hline Urtica chamaedryoides & Nettle & 4.42 \\
\hline Clematis virginiana & Virgins bower clematis & 4.57 \\
\hline Eupatorium rugosum & White snakeroot & 4.67 \\
\hline Cocculus carolinus & Snailseed & 4.78 \\
\hline Viola missouriensis & Missouri violet & 4.83 \\
\hline Hypericum hypericoides & St. Johnswort & 5.25 \\
\hline Mitchella repens & Partridge berry & 5.32 \\
\hline Arundinaria gigantea & Giant cane & 5.34 \\
\hline Vitis rotundifolia & Muscadine & 5.89 \\
\hline Gelsemium sempervirens & Carolina jessamine & 6.31 \\
\hline Sanicula canadensis & Black snakeroot & 6.39 \\
\hline Galium aparine & Catchweed bedstraw & 6.50 \\
\hline Carex albolutescens & Sedge & 6.50 \\
\hline Cynanchum laeve & Cynanchum & 6.50 \\
\hline Lonicera sempervirens & Trumpet honeysuckle & 6.50 \\
\hline
\end{tabular}


Examples of FTI numbers by life stage for woody species are presented in Table 5. Although differences between FTI numbers for tree and sapling life stages are not great, FTI numbers for saplings tend to be slightly higher than for trees because saplings are generally more sensitive to flooding than trees. The sapling life stage also tends to occur in a broader range of zones than the tree life stage due to temporal variations in selective pressures (e.g., competition and response to flooding). FTI numbers of seedlings have little value in determining hydrologic zones because they only reflect seed dispersal potential and germination wherever seedbed conditions are favorable. For example, seedlings of least tolerant species (e.g., Sassafras albidum)

Table 5

Variations in Species Flood Tolerance Index Numbers According to Life Stage

\begin{tabular}{lccc}
\hline \multicolumn{1}{c}{ Scientific Name } & Tree & Sapling & Seedling \\
Taxodium distichum & 2.97 & 3.33 & 3.09 \\
Gleditsia aquatica & 3.50 & 3.15 & 3.27 \\
Carya aquatica & 3.54 & 3.70 & 3.69 \\
Quercus lyrata & 3.73 & 3.99 & 3.80 \\
Fraxinus pennsylvanica & 4.44 & 4.27 & 4.00 \\
Quercus nuttallii & 4.50 & 4.50 & 4.50 \\
Acer negundo & 4.83 & 5.20 & 5.58 \\
Celtis laevigata & 4.84 & 4.37 & 4.77 \\
Liquidambar styraciflua & 5.03 & 5.52 & 4.87 \\
Quercus nigra & 5.73 & 5.92 & 5.85 \\
Sassafras albidum & 6.50 & 6.50 & 6.07 \\
& & & \\
\hline
\end{tabular}


occasionally occur in lower zones (Table D-3, Zone 3), but the individuals do not survive to maturity unless the hydrologic regime is drastically altered.

The average importance value was plotted for each species in every zone where it occurred in the study. Although a species can be expected to occur in a number of zones, many had a peak occurrence in a particular zone (Figure 4). However, because this study did not analyze a continuous gradient, FTI numbers were calculated from mean importance values across the entire study and do not necessarily represent the maximum in ecological amplitude for a species.

Three general species distribution patterns are shown in Figure 4. The first pattern includes species such as water tupelo (NYAQ) and bald cypress (TADI), in which mean importance value is greatest in Zone 2 and the species no longer occurs after either Zone 3 or 4 . This pattern is indicative of species having the strongest competitive advantage in areas of greatest duration of inundation/soil saturation. The second pattern is typified by species such as water oak (QUNI), loblolly pine (PITA), sassafras (SAAL), and white oak (QUAL), in which the greatest mean importance value occurs in Zone 6 (uplands) and decreases from Zone 5 to 2. Hence they have a stronger competitive advantage in areas where inundation/soil saturation is less than 5 percent of the growing season. However, some of these species (e.g., water oak and loblolly pine) may occasionally occur as dominants in wetlands. The third pattern is typified by species having the greatest mean importance values in Zones 3 , 4, and 5. Species in this group sometimes occur as dominant species in either Zone 2 or 6 , but are best adapted for occurrence at some point in Zones 3, 4, and 5. Species having the greatest mean importance values 


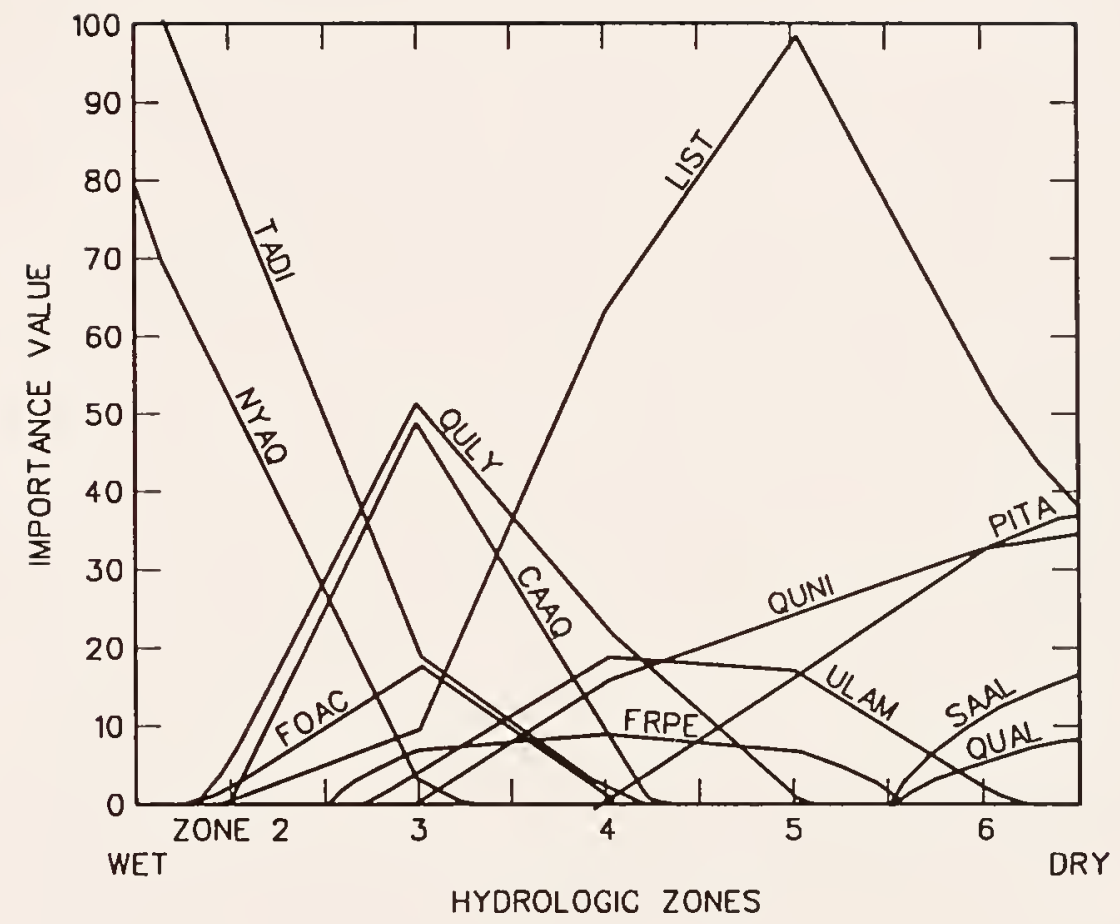

Figure 4. Ecological amplitude of some commonly occurring species; CAAQ: Carya aquatica; FOAC: Forestiera acuminata; FRPE: Fraxinus pennsylvanica; LIST: Liquidambar styraciflua; NYAQ: Nyssa aquatica; PITA: Pinus taeda; QUAL: Quercus alba; QULY: Quercus lyrata; QUNI: Quercus nigra; SAAL: Sassafras albidum; TADI: Taxodium distichum; and ULAM: Ulmus americana 
in Zone 3 are overcup oak (QULY) and bitter pecan (CAAQ), while American elm (ULAM) and sweetgum (LIST) develop the greatest mean importance values in Zones 4 and 5 , respectively.

Other systems have been developed to identify the degree of wetness for which a species is best adapted (e.g., Hook 1984, Reed 1988). These systems used qualitative descriptions, such as "most tolerant" or "obligate hydrophyte," and are based primarily on the literature or "expert evaluations" and not on a single coordinated study. Species evaluations were also made by life forms in this study, and no such distinction was made in the other two systems. However, all three systems, including the FTI numbers, were developed to identify a degree of wetness for which a species is best adapted. They all have five categories that vary from wettest to driest. Therefore, an obvious comparison would be to compare species having an FTI integer of 2, with the most tolerant and obligate designation, an FTI integer of 3 , with the highly tolerant and facultative wet description, etc.

Species identified in this study are listed along with corresponding FTI numbers and ratings of those species from the systems developed by Hook and Reed in Appendix E. Among selected tree species shown in Table 6, all species having an FTI number from 2 to 4 are obligate plants (OBL) in the National List of Plant Species that Occur in Wetlands: Southeast (Region 2) (Reed 1988) and have a water-loggingtolerance rating of most or highly tolerant (Hook 1984). All listed species except Pinus taeda that have an FTI number of 6 to 6.5 are facultative upland (FACU) species (Reed 1988) and are rated by Hook (1984) as the least-tolerant species. P. taeda (FTI-6.41) has an indicator status of facultative (FAC) and is rated by Hook as moderately tolerant 
Table 6

Comparison of Three Water-Tolerance Ratings for

Selected Bottomland Forest Tree Species

\begin{tabular}{|c|c|c|c|}
\hline Species & $\begin{array}{c}\text { FTI }^{a} \pm \text { Standard } \\
\text { Deviation } \\
\end{array}$ & $\begin{array}{c}\text { NWI }^{\mathrm{b}} \\
\text { Status } \\
\text { Region 2 } \\
\end{array}$ & $\begin{array}{c}\text { Waterlogging } \\
\text { Tolerance } \\
\text { Rating Group } \\
\end{array}$ \\
\hline Nyssa aquatica & $2.62 \pm 0.20$ & OBL & Most tolerant \\
\hline Salix nigra & $2.83 \pm 0.58$ & OBL & Most tolerant \\
\hline Fraxinus caroliniana & $2.87 \pm 0.41$ & OBL & Most tolerant \\
\hline Taxodium distichum & $2.97 \pm 0.61$ & OBL & Most tolerant \\
\hline Forestiera acuminata & $3.48 \pm 0.50$ & OBL & Most tolerant \\
\hline Gleditsia aquatica & $3.50 \pm 0.00$ & OBL & Highly tolerant \\
\hline Carya aquatica & $3.54 \pm 0.34$ & OBL & Highly tolerant \\
\hline Quercus lyrata & $3.73 \pm 0.68$ & OBL & Highly tolerant \\
\hline Betula nigra & $4.01 \pm 1.73$ & OBL & $\begin{array}{l}\text { Moderately } \\
\text { tolerant }\end{array}$ \\
\hline Diospyros virginiana & $4.13 \pm 0.82$ & FAC & $\begin{array}{r}\text { Moderately } \\
\text { tolerant }\end{array}$ \\
\hline Acer rubrum & $4.21 \pm 0.68$ & FAC & $\begin{array}{r}\text { Moderately } \\
\text { tolerant }\end{array}$ \\
\hline Fraxinus pennsylvanica & $4.44 \pm 0.67$ & FACW & $\begin{array}{r}\text { Moderately } \\
\text { tolerant }\end{array}$ \\
\hline Ulmus americana & $4.46 \pm 0.62$ & FACW & $\begin{array}{r}\text { Moderately } \\
\text { tolerant }\end{array}$ \\
\hline Quercus phellos & $4.81 \pm 1.07$ & FACW & $\begin{array}{r}\text { Moderately } \\
\text { tolerant }\end{array}$ \\
\hline Acer negundo & $4.83 \pm 0.47$ & FACW & $\begin{array}{l}\text { Moderately } \\
\text { tolerant }\end{array}$ \\
\hline Carpinus caroliniana & $4.84 \pm 0.61$ & FAC & Weakly tolerant \\
\hline Celtis laevigata & $4.84 \pm 0.56$ & FACW & Weakly tolerant \\
\hline Liquidambar styraciflua & $5.03 \pm 0.65$ & FAC+ & $\begin{array}{r}\text { Moderately } \\
\text { tolerant }\end{array}$ \\
\hline Carya illinoensis & $5.57 \pm 1.01$ & $\mathrm{FAC}+$ & Weakly tolerant \\
\hline Pinus taeda & $6.41 \pm 0.14$ & FAC & $\begin{array}{l}\text { Moderately } \\
\text { tolerant }\end{array}$ \\
\hline Cornus florida & $6.50 \pm 0.00$ & FACU & Least tolerant \\
\hline Fagus grandifolia & $6.50 \pm 0.00$ & FACU & Least tolerant \\
\hline Quercus alba & $6.50 \pm 0.00$ & FACU & Least tolerant \\
\hline Sassafras albidum & $6.50 \pm 0.00$ & FACU & Least tolerant \\
\hline
\end{tabular}

a Mean for all study sites.

b Taken from Reed (1988) (see Appendix A).

c Taken from Hook (1984) (see Appendix B). 
of waterlogged soils. All species except Betula nigra that have an FTI number of 4 to 6 are facultative wet (FACW) or FAC and are rated as moderately or weakly tolerant. B. nigra, an obligate species, occurs on well-drained soils, often on natural berms. FTI numbers were computed only for bottomland forests and do not reflect occurrence in other wetland types (e.g., pocosins and Carolina bays); thus, slight deviations from the above pattern should be expected for some species. Also some species may have genetic variants that possess varying degrees of flood tolerance. Hook et al. (1988) reported that interspecific variation in tolerant to waterlogging exists in loblolly pine ( inus taeda). This may also be true of other species.

Although the system using the National Wetlands Inventory (NWI) indicator status (Reed 1988) does not allow comparison of hydrologic definitions, the actual average duration of flooding in this study compared with Hook's (1984) waterlogging tolerance rating definitions yields strong agreement. For example, assuming an average 225-day growing season, the most tolerant rating can be defined as approximately 200 days (Appendix E). The boundary between Zones 2 and 3 (which theoretically would be slightly drier because the designation most tolerant is best compared to Zone 2, not the boundary between Zones 2 and 3 ) has a duration of inundation/soil saturation that ranges from 92 to 198 days. Highly tolerant ranges from 30 to 90 days versus 20 to 66 days for the Zone $3-4$ boundary. Weakly tolerant ranges from 1 to 4 weeks, while the Zone 4-5 boundary ranges from 8 to 31 days. "Least tolerant" is defined as waterlogging for a few days, but usually less than 2 percent of the growing season. Using the 225-day growing season, 
this could be assumed to be 3 or 4 days. The boundary between Zones 5 and 6 varied from less than 1 to 10 days.

\section{Weighted Averaging}

Weighted average estimates of species optima in this study were calculated as FTI values as previously described, with importance values used as the indicator of species abundance at each site.

The use of the weighted averaging approach requires that a number of conditions be met, including: (1) species exhibit unimodal abundance distributions, (2) species optima are equally spaced along the environmental variable, (3) species have equal tolerances of the environmental variable, and (4) species have equal maximum values for the environmental variable. Strict adherence to some of these conditions is not always possible. Additional considerations should also be noted. Species-rich samples should not occur at one end of the gradient. Environmental tolerances of species should not vary substantially. The standard deviation of FTI numbers is an estimate of tolerance in this analysis. Species with narrow tolerances have low FTI numbers and standard deviations and those with wide tolerance have high standard deviations .

Some of the aforementioned conditions are not strictly met in this study. Although species richness was fairly even across the hydrologic gradient, few species had a peak abundance in Zone 5, perhaps because Zone 5 was undersampled $(n=4)$ relative to the other zones. The condition of a unimodal abundance distribution is upheld for tree species with peaks in hydrologic Zones 2, 3, and 6, but several species (e.g.,

Ilex opaca, Quercus nigra, Nyssa sylvatica, and Liquidambar styraciflua) 
exhibit bimodal distributions with peaks in Zones 4 and 6 . Again, this pattern may have been influenced by fewer samples being taken in Zone 5 . The condition of equal tolerances is also violated somewhat. For instance, those species with abundance peaks in Zones 2 and 6 have narrow tolerances; whereas, those that commonly occur in Zone 4 are also fairly common in other hydrologic zones as well. However, these deviations from the conditions for weighted averaging analysis do not necessarily render the FTI method invalid. Additional analyses were applied to help determine its validity.

\section{Statistical Analysis of the Vegetation Data}

To evaluate a method of identifying hydrologic zones based on vegetative associations, the analysis must be based on common species occurring within the region of interest. Species that occur infrequently may be excellent indicators of hydrologic conditions when present, but their limited abundance makes evaluating their usefulness in determining a hydrologic zone difficult. For this reason, species occurring relatively infrequently in this study were not used in testing the validity of the weighted averages (FTI numbers). More than half of the 74 tree species $(n=44)$ recorded had 20 or fewer individuals throughout the study region and, therefore, were not used in the analyses. The remaining 30 tree species accounted for 90.4 percent of the individual trees. One hundred and eighteen species of saplings and shrubs were recorded. Only those 29 species which represented at least one percent or more of the total and together accounted for 78 percent of the total saplings and shrubs data set were used in the statistical analysis. A total of 31 vine species were recorded; the 20 more common 
species accounted for 96.5 percent of all individuals and were the species analyzed statistically. The herbaceous ground-cover data set contained 268 species. Most occurred only rarely in this study, and only 30 species whose abundances equaled or exceeded 1 percent of the total herb individuals were included in the analysis. These species accounted for 48.9 percent of all individuals in this vegetative category.

\section{Cluster Analyses}

A method of calibration suggested by Ter Braak and Prentice (1988) is cluster analysis in which an environmental value (hydrologic zone) is predicted through use of species abundance indicators (relative frequency). In addition to relative frequency, cluster membership was used as a predictor of hydrologic zone. Species were clustered according to similar abundance distributions across the hydrologic gradient.

Cluster analysis was used to group the 30 tree species into five clusters based on the five hydrologic zones. Results (Figure 5) show that, with the exception of chinaberry (MEAZ) and deciduous holly (ILDE), five distinct groups can be discerned. Table 7 gives the relative frequencies of occurrence of each species in each hydrologic zone (species are grouped by cluster). Inspection of the data reveals why chinaberry and deciduous holly did not group readily. Chinaberry is the only species that occurs almost exclusively in Zone 5. Its occurrence is also restricted to a single site. The distribution of deciduous holly peaks in Zones 2 and 3 , but not to the extent of other common species in these zones. Because chinaberry and deciduous holly did not group readily, they were eliminated from further analysis. 


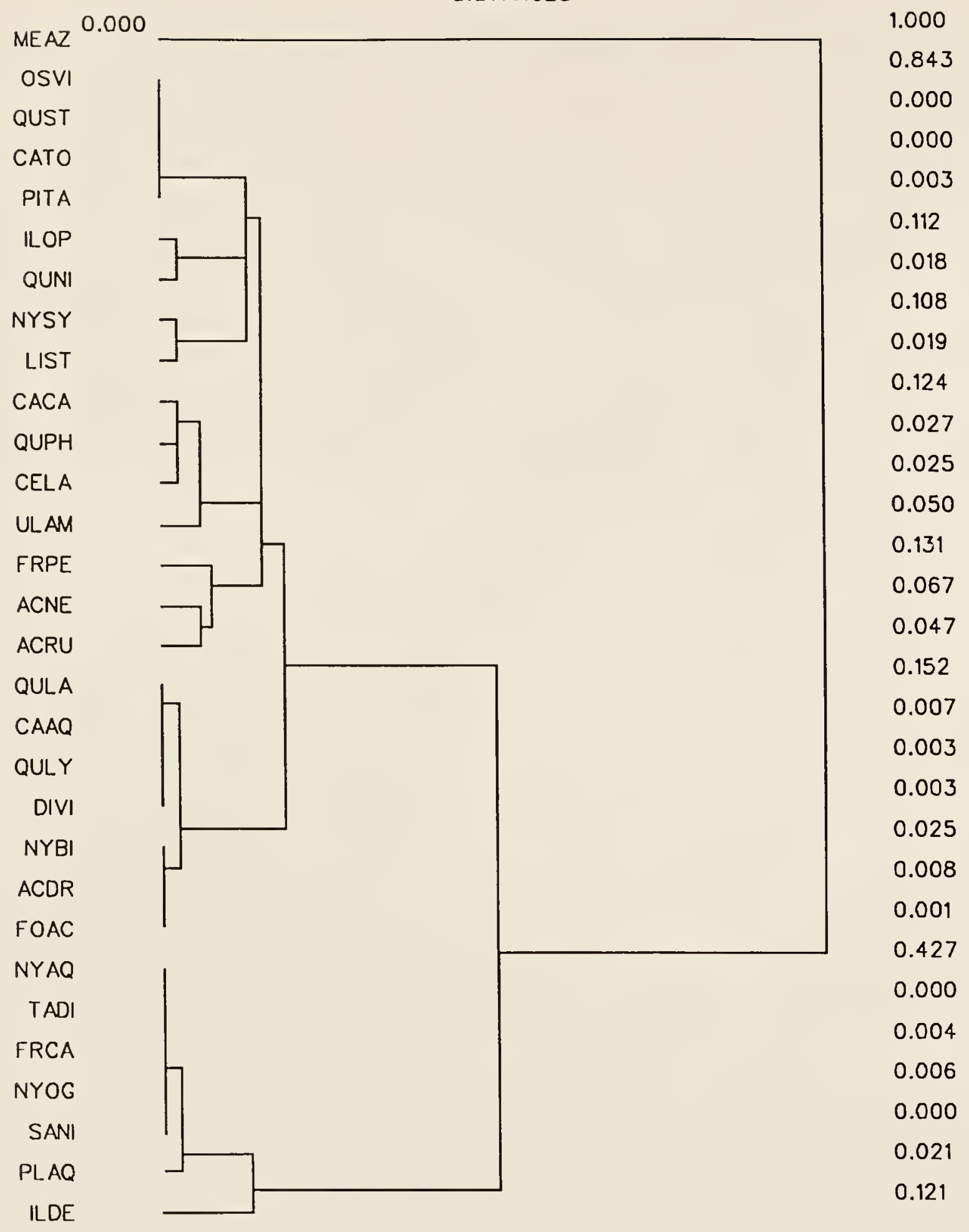

Figure 5. Cluster diagram for trees. Distance metric is 1-Pearson correlation coefficient, single linkage method (nearest neighbor) 
Table 7

Relative Frequencies in Each Hydrologic Zone of Tree Species Used in the Statistical Analyses: Groupings of Species

Correspond to Cluster Membership

\begin{tabular}{|c|c|c|c|c|c|c|}
\hline \multirow[b]{2}{*}{ Species } & \multicolumn{6}{|c|}{ Hydrologic Zone } \\
\hline & 2 & 3 & 4 & 5 & 6 & Cluster \\
\hline $\mathrm{NYAQ}^{\mathrm{a}}$ & 85.0 & 15.0 & 0 & 0 & 0 & \\
\hline TADI & 82.7 & 15.6 & 1.8 & 0 & 0 & \\
\hline FRCA & 79.1 & 20.9 & 0 & 0 & 0 & 1 \\
\hline NYOG & 93.9 & 6.1 & 0 & 0 & 0 & \\
\hline SANI & 96.5 & 3.5 & 0 & 0 & 0 & \\
\hline PLAQ & 67.7 & 31.6 & 0.7 & 0 & 0 & \\
\hline QULA & 0.9 & 70.1 & 26.2 & 0 & 2.8 & \\
\hline CAAQ & 0.8 & 80.0 & 19.2 & 0 & 0 & \\
\hline QULY & 6.5 & 72.9 & 20.0 & 0.6 & 0 & \\
\hline DIVI & 0 & 70.6 & 20.6 & 2.9 & 5.9 & 2 \\
\hline NYBI & 15.3 & 84.7 & 0 & 0 & 0 & \\
\hline ACDR & 7.1 & 88.1 & 4.8 & 0 & 0 & \\
\hline FOAC & 3.6 & 94.0 & 2.4 & 0 & 0 & \\
\hline CACA & 0.6 & 2.8 & 63.7 & 17.0 & 15.9 & \\
\hline QUPH & 0 & 8.6 & 74.1 & 10.3 & 6.9 & \\
\hline CELA & 2.0 & 9.8 & 62.8 & 21.6 & 3.9 & \\
\hline ULAM & 1.9 & 21.2 & 50.0 & 25.0 & 1.9 & 3 \\
\hline FRPE & 0 & 45.2 & 42.9 & 11.9 & 0 & \\
\hline ACNE & 0 & 31.1 & 53.3 & 4.4 & 11.1 & \\
\hline ACRU & 6.8 & 38.4 & 52.0 & 1.4 & 1.4 & \\
\hline ILOP & 0 & 0 & 41.7 & 0 & 58.3 & \\
\hline QUNI & 0 & 1.6 & 32.8 & 7.4 & 58.2 & 4 \\
\hline NYSY & 0 & 0 & 55.9 & 5.9 & 38.2 & \\
\hline LIST & 0.3 & 6.0 & 45.4 & 14.9 & 33.3 & \\
\hline OSVI & 0 & 0 & 0 & 0 & 100 & \\
\hline QUST & 0 & 0 & 0 & 0 & 100 & 5 \\
\hline CATO & 0 & 0 & 0 & 0 & 100 & \\
\hline PITA & 0 & 0 & 7.3 & 0 & 92.7 & \\
\hline
\end{tabular}

a Represents the first two letters of the plant genus and the first two letters of the species name, i.e., NYAQ stands for Nyssa aquatica.

Species codes for all species are identified in Appendix E. 
A closer inspection of Table 7 indicates that the five clusters have modal peaks that correspond, with varying amplitude, to the five hydrologic zones. Trees in cluster 1 are found almost exclusively in Zones 2 and 3 . Likewise, trees in cluster 2 occur most commonly in Zone 3. Cluster 5 had the most restrictive distribution, with three of the four species occurring exclusively in Zone 6 . The remaining clusters, 3 and 4, had less distinctive modes, but exhibited greater distributions in Zones 4 and 6 .

Cluster analysis on the entire sapling and shrub data set did not produce distinct groupings (Figure 6). Silver bell (HADI) was not evaluated further because it occurred at a single site. The data set was split into the two sapling and shrub (bush) components, and cluster analysis was recalculated on each component. The saplings alone $(n=17)$ grouped more distinctly (Figure 7$)$ than the shrubs $(n=11)$ (Figure 8). Shrubs, therefore, were not used in any further analyses. Saplings alone grouped into five distinct groups but not as strongly as trees. The relative frequency of occurrence and cluster membership of the sapling species are given in Table 8 .

The vine data produced five clusters, morning glory (IPWR) being a single species cluster corresponding to Zone 2 (Figure 9). Two vine species poison ivy (TORA) and trumpet creeper (CARA) were not included in larger clusters, largely because of their apparent wide tolerances of hydrologic conditions. Table 9 depicts the relative abundance distributions of each vine species across the hydrologic gradient within a cluster and illustrates a pattern similar to but not as strong as that of the tree species. 


\section{DIST ANCES}

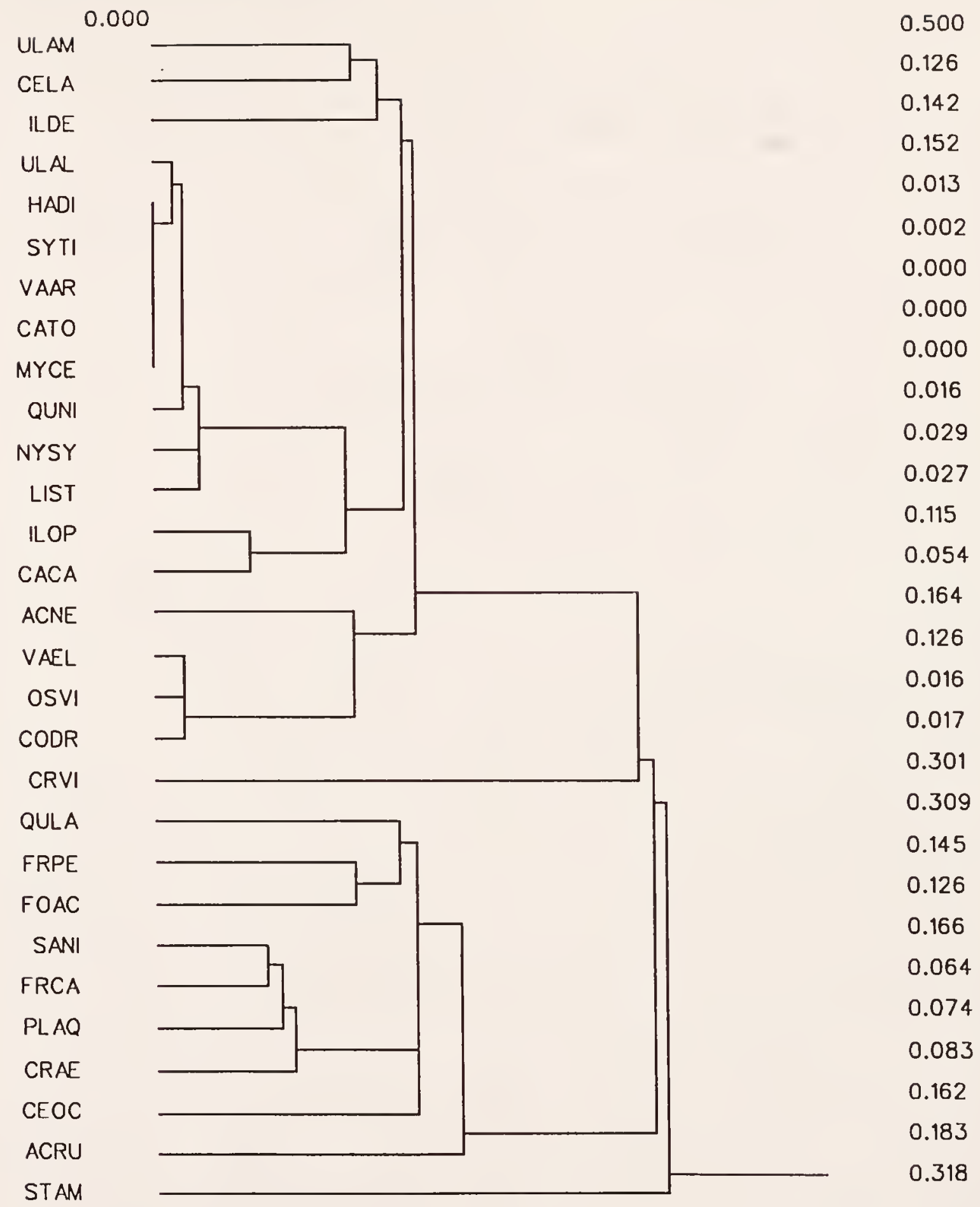

Figure 6. Cluster diagram for saplings and shrubs. Distance metric is 1 -Pearson correlation coefficient, single linkage method (nearest neighbor) 


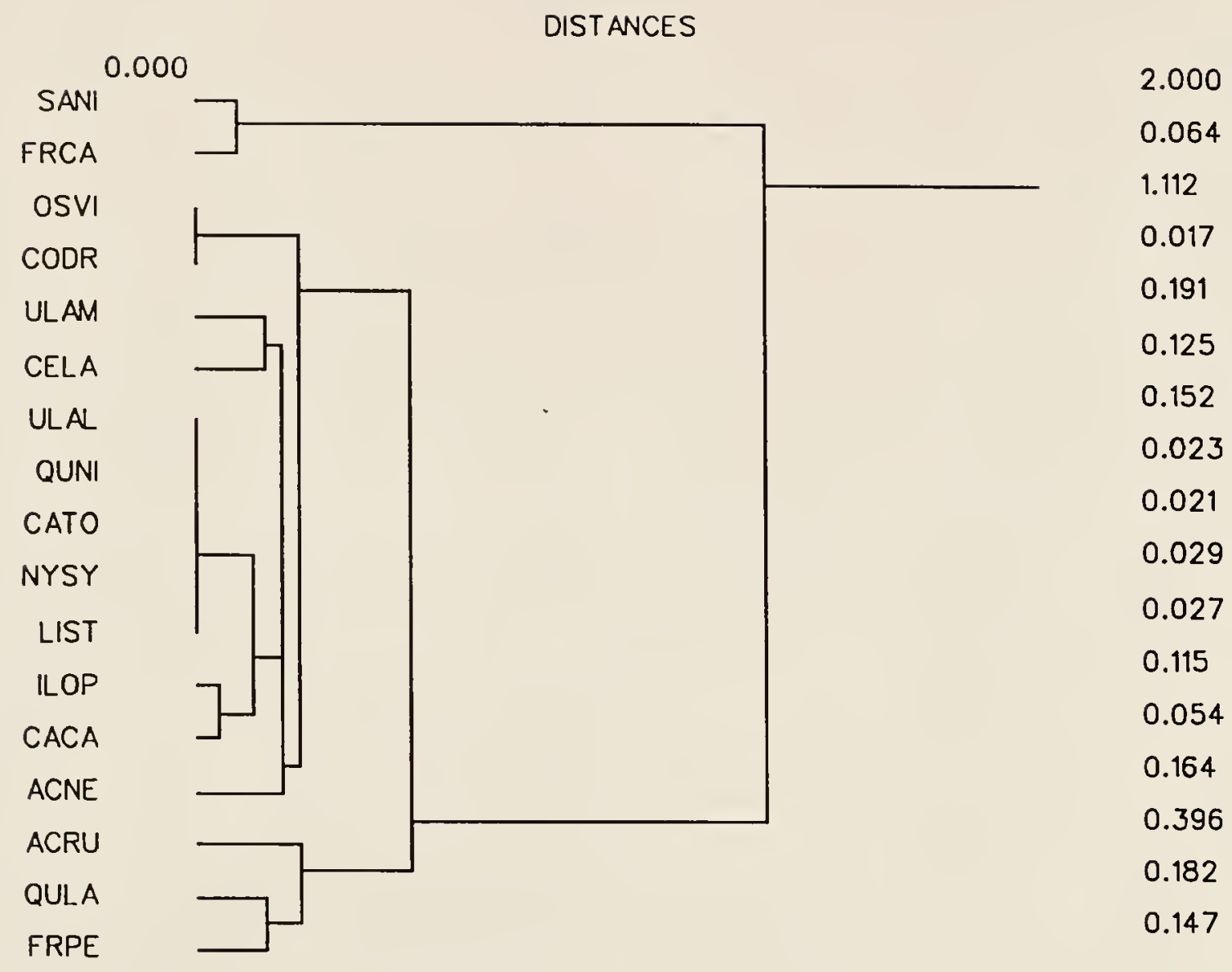

Figure 7. Cluster diagram for saplings alone. Distance metric is 1-Pearson correlation coefficient, single linkage method (nearest neighbor) 


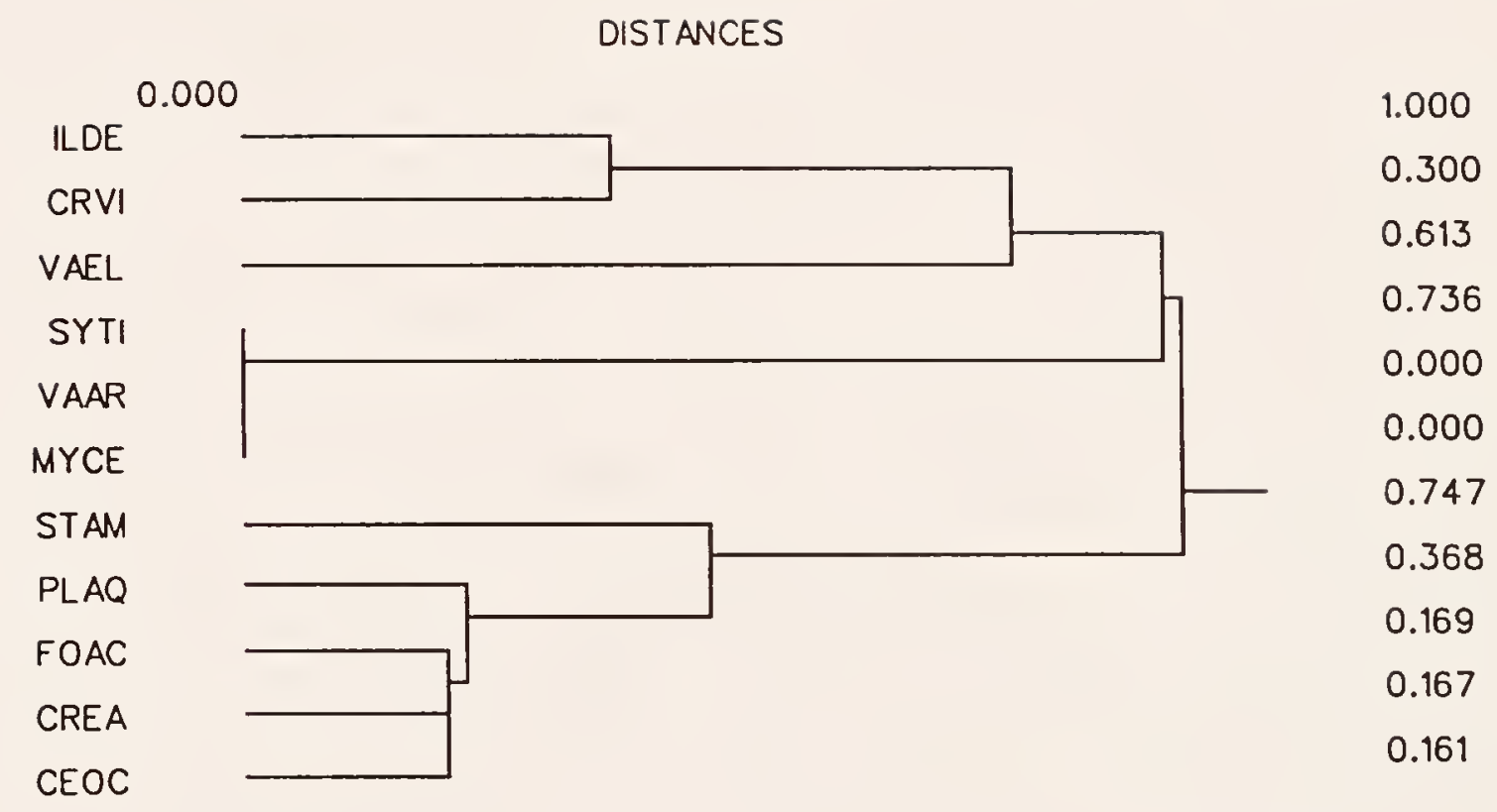

Figure 8. Cluster diagram for shrubs alone. Distance metric is 1 Pearson correlation coefficient, single linkage method (nearest neighbor) 
Table 8

Relative Frequency of Occurrence of Each Sapling Species in the Hydrologic Zones along with Their Cluster Memberships

\begin{tabular}{|c|c|c|c|c|c|c|}
\hline Species & 2 & 3 & 4 & 5 & 6 & Cluster \\
\hline SANI & 99.4 & 0.6 & 0.0 & 0.0 & 0.0 & 1 \\
\hline FRCA & 61.0 & 21.2 & 2.7 & 0.0 & 15.1 & \\
\hline ACRU & 1.4 & 35.8 & 35.1 & 4.6 & 23.0 & \\
\hline FRPE & 0.0 & 50.0 & 21.9 & 21.9 & 6.3 & 2 \\
\hline QULA & 4.7 & 53.3 & 36.7 & 3.6 & 1.8 & \\
\hline ULAM & 0.0 & 2.0 & 42.1 & 32.2 & 23.7 & 3 \\
\hline CELA & 0.0 & 13.1 & 47.5 & 19.5 & 19.9 & \\
\hline OSVI & 0.0 & 0.0 & 0.0 & 71.2 & 28.8 & 4 \\
\hline CODR & 0.0 & 0.0 & 1.5 & 80.0 & 18.5 & \\
\hline ULAL & 0.0 & 0.0 & 0.8 & 17.7 & 81.5 & \\
\hline QUNI & 0.0 & 0.4 & 14.2 & 11.1 & 74.2 & \\
\hline CATO & 0.0 & 0.0 & 0.0 & 0.0 & 100.0 & \\
\hline NYSY & 0.0 & 0.0 & 24.7 & 22.7 & 52.6 & 5 \\
\hline LIST & 0.0 & 5.4 & 24.2 & 14.6 & 55.8 & \\
\hline ILOP & 0.0 & 0.0 & 55.5 & 5.0 & 39.5 & \\
\hline CACA & 0.2 & 1.4 & 40.6 & 15.7 & 42.0 & \\
\hline
\end{tabular}

The herb data also did not cluster distinctly (Figure 10). Inspection of the abundance distributions of the herbaceous species reveals an absence of strong unimodal peaks that correspond to hydrologic zones; therefore, this vegetative type is less useful in classification. The lack of significant clustering of the shrub and herbaceous data sets was consistent with the results of ordination attempts of the ground layer at Neches River sites by Mohler (1979). Mohler concluded that the herbs and low shrubs were relatively unimportant components of the forest when compared to the trees. Clearly, the low shrubs and herbaceous species are more prone to bias due to successional processes and vegetative change caused by local disturbances which may be unrelated to the environmental gradient. 


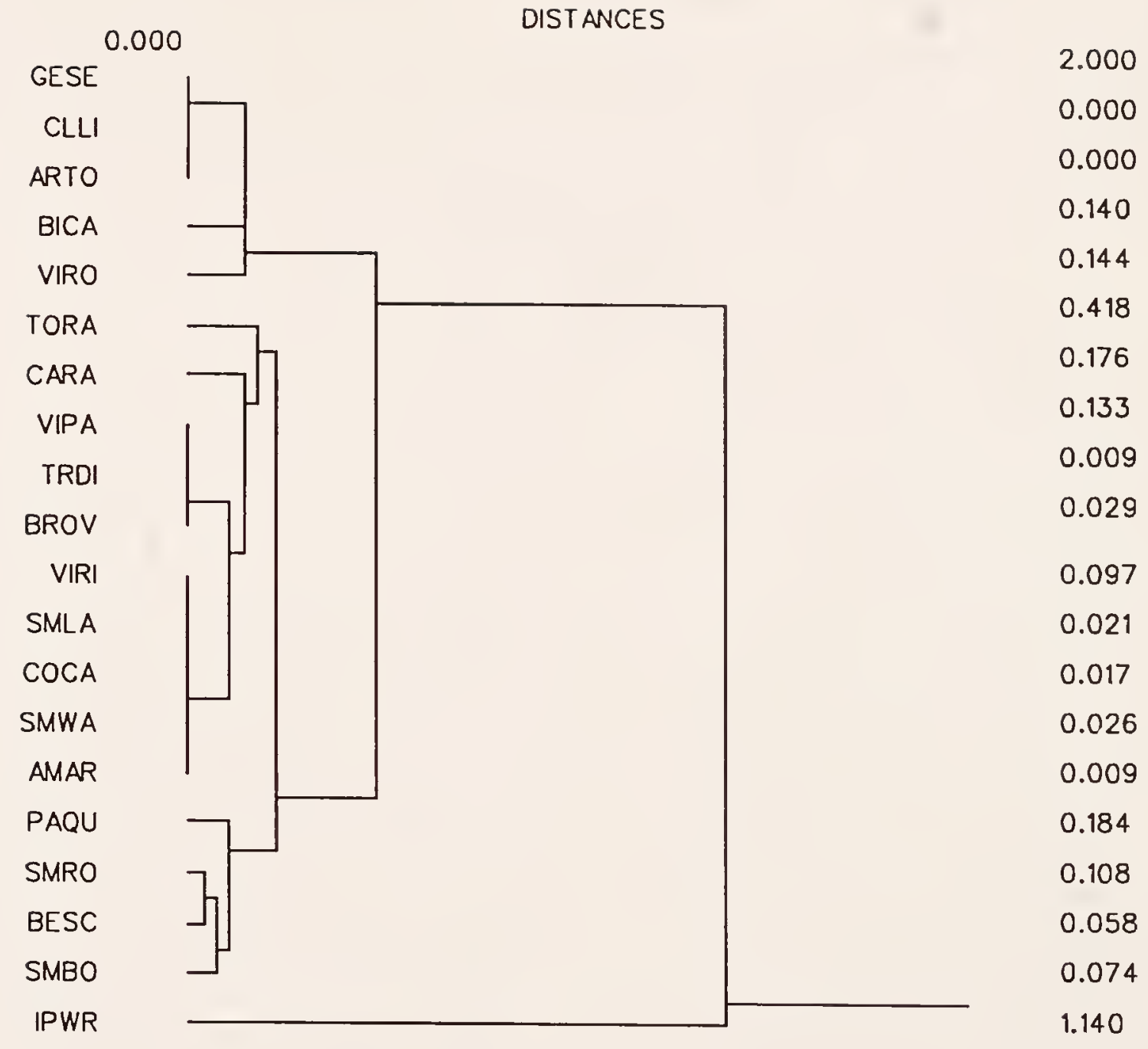

Figure 9. Cluster diagram for vines. Distance metric is 1-Pearson correlation coefficient, single linkage method (nearest neighbor) 
Table 9

Relative Frequencies in Each Hydrologic Zone of the Vine Species Used in Statistical Analyses

\begin{tabular}{|c|c|c|c|c|c|c|}
\hline \multirow[b]{2}{*}{ Species $^{a}$} & \multicolumn{6}{|c|}{ Hydrologic Zone } \\
\hline & 2 & 3 & 4 & 5 & 6 & Cluster \\
\hline IPWR & 100 & 0 & 0 & 0 & 0 & 1 \\
\hline VIPA & 0 & 64.1 & 30.5 & 5.5 & 0 & \\
\hline TRDI & 2.1 & 70.2 & 26.9 & 0 & 0.8 & 2 \\
\hline BROV & 13.4 & 65.2 & 17.8 & 3.6 & 0 & \\
\hline VIRI & 1.0 & 33.3 & 43.8 & 7.6 & 14.3 & \\
\hline SMLA & 1.8 & 47.4 & 45.6 & 0 & 5.3 & \\
\hline COCA & 0 & 41.9 & 52.9 & 0 & 5.2 & 3 \\
\hline SMWA & 9.1 & 36.4 & 53.8 & 0 & 0.7 & \\
\hline AMAR & 13.2 & 37.2 & 46.3 & 0 & 3.3 & \\
\hline PAQU & 1.5 & 55.9 & 2.2 & 40.4 & & \\
\hline SMRO & 0 & 2.4 & 71.4 & 7.1 & 19.1 & 4 \\
\hline BESC & 4.6 & 13.7 & 61.1 & 14.5 & 6.1 & \\
\hline SMBO & 6.7 & 13.3 & 43.3 & 26.7 & 10.0 & \\
\hline GESE & 0 & 0 & 0 & 0 & 100 & \\
\hline CLLI & 0 & 0 & 0 & 0 & 100 & \\
\hline ARTO & 0 & 0 & 0 & 0 & 100 & 5 \\
\hline $\mathrm{BICA}$ & 0 & 19.8 & 3.1 & 25.0 & 52.1 & \\
\hline VIRO & 1.6 & 6.0 & 20.0 & 24.4 & 48.0 & \\
\hline
\end{tabular}

a Groupings of species correspond to cluster membership.

Results of cluster analyses suggest that cluster membership for tree data provide better indicators of hydrologic zones than saplings or vines. Shrubs and herbaceous species would be the least useful of all strata types.

\section{Discriminant Function Analysis}

Discriminant function analysis (DFA) is used to determine functions which allow one to classify an individual into one of the 


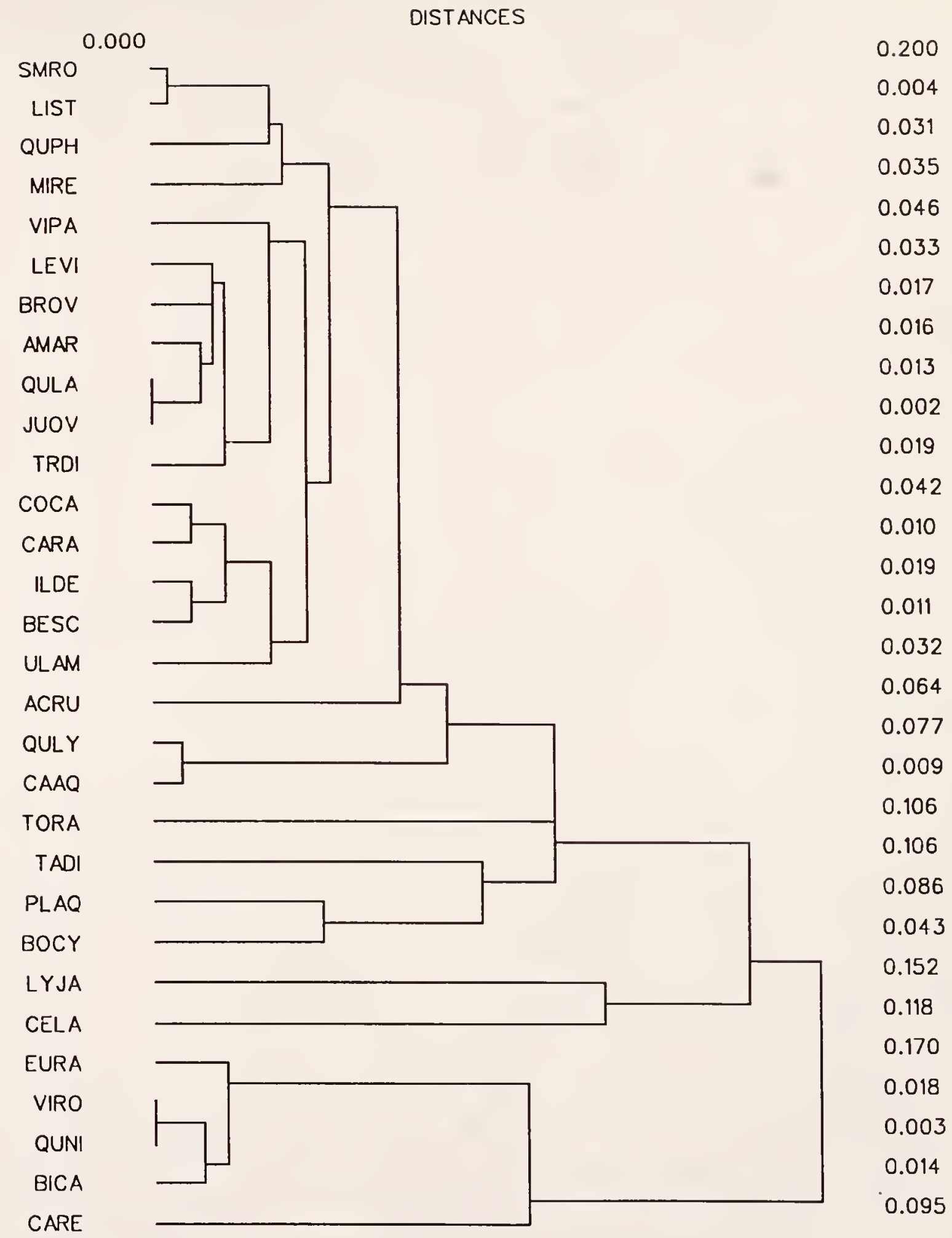

Figure 10. Cluster diagram for herbs. Distance metric is 1-Pearson correlation coefficient, single linkage method (nearest neighbor) 
hydrologic zones using a number of independent variables. The independent variables in this analysis are the average importance values for each tree cluster and vine cluster in each zone. In cases where only one species in a cluster was present in a zone, that importance value alone was used. Table 10 lists the data set upon which this analysis was based.

Three analyses were performed using DFA. The first analysis developed a classification model using only the importance value from tree clusters. This model correctly classified 47 of 55 sites for an overall misclassification rate of 14.6 percent (Table 11). In all cases, errors involved an assignment to a neighboring zone. For instance, a single Zone 3 site was assigned to Zone 2, and three Zone 6 sites were assigned to Zone 5. The greatest error in classification occurred for Zone 4 sites, which is expected because of the greater tolerance of species for this zone. As previously shown (Figure 4), Zone 4 is that portion of the hydrologic gradient that has species common to all three distribution patterns identified. Three Zone 6 sites were assigned to Zone 5 primarily due to the lack of Zone 6 species being identified as commonly occurring. A better agreement would be expected if all species were used.

The second model examined the ability of vine cluster importance values to predict zone. Although vines did not cluster as well as trees, a DFA was examined because their cluster patterns were similar. However, this model correctly classified only 26 of 55 zones for a 52 percent misclassification. This model was not considered adequate, and the results of its classification are not presented. 
Table 10

Mean Importance Values for Species in Each Cluster Used in the DFA, Arranged by Zone/Sample

\begin{tabular}{|c|c|c|c|c|c|c|c|c|c|}
\hline Zone & $\mathrm{TC1}^{\mathrm{a}}$ & $\mathrm{TC2}$ & TC3 & TC4 & TC5 & $\mathrm{VC2}$ & $\mathrm{VC} 3$ & VC4 & VC5 \\
\hline 2 & 78.77 & 0 & 0 & 0 & 0 & 0 & 0 & 0 & 0 \\
\hline 2 & 70.26 & 0 & 0 & 0 & 0 & 0 & 0 & 0 & 0 \\
\hline 2 & 65.12 & 0 & 0 & 0 & 0 & 0 & 0 & 0 & 0 \\
\hline 2 & 91.7 & 8.26 & 8.32 & 0 & 0 & 64.06 & 0 & 203.9 & 0 \\
\hline 2 & 62.38 & 0 & 0 & 0 & 0 & 0 & 0 & 0 & 0 \\
\hline 2 & 83.49 & 21.16 & 9.48 & 5.66 & 0 & 0 & 103.24 & 0 & 162.5 \\
\hline 2 & 73.45 & 6.19 & 0 & 0 & 0 & 141.17 & 38.76 & 53.5 & 0 \\
\hline 2 & 68.41 & 12.58 & 0 & 0 & 0 & 112.22 & 32.13 & 0 & 11.33 \\
\hline 2 & 58.62 & 32.76 & 0 & 0 & 0 & 0 & 41.32 & 0 & 0 \\
\hline 2 & 58.12 & 4.19 & 0 & 0 & 0 & 0 & 300 & 0 & 0 \\
\hline 2 & 74.99 & 33.22 & 3.34 & 0 & 0 & 300 & 0 & 0 & 0 \\
\hline 3 & 29.57 & 39.47 & 0 & 8.4 & 0 & 101.56 & 63.02 & 33.87 & 0 \\
\hline 3 & 30.3 & 47.5 & 0 & 19.12 & 0 & 68.2 & 47.04 & 0 & 0 \\
\hline 3 & 0 & 50.08 & 26.13 & 0 & 0 & 12.98 & 65.86 & 8.65 & 0 \\
\hline 3 & 0 & 71.81 & 0 & 0 & 0 & 100 & 0 & 0 & 0 \\
\hline 3 & 24.37 & 66.92 & 7.92 & 0 & 0 & 93.14 & 0 & 4.89 & 0 \\
\hline 3 & 22.84 & 84.85 & 22.59 & 0 & 0 & 51.13 & 16.28 & 5.57 & 0 \\
\hline 3 & 99.86 & 25.52 & 6.41 & 0 & 0 & 82.8 & 45.12 & 0 & 0 \\
\hline 3 & 30 & 47.29 & 11.72 & 0 & 0 & 53.87 & 32.81 & 18.92 & 0 \\
\hline 3 & 0 & 85.22 & 13.67 & 11.78 & 0 & 19.27 & 28.8 & 22.65 & 58.54 \\
\hline 3 & 32.72 & 54.74 & 10.42 & 0 & 0 & 89.33 & 78.78 & 0 & 53.11 \\
\hline 3 & 7.39 & 48.01 & 16.18 & 37.94 & 0 & 4.2 & 34.88 & 0 & 12.78 \\
\hline 3 & 39.94 & 56.21 & 14.8 & 15.66 & 0 & 0 & 233.26 & 0 & 0 \\
\hline 3 & 10.06 & 99.1 & 47.87 & 13.23 & 0 & 0 & 144.56 & 47.53 & 5.97 \\
\hline 3 & 44.79 & 43.95 & 17.52 & 0 & 0 & 130.77 & 0 & 0 & 0 \\
\hline 3 & 11.06 & 48.2 & 36.72 & 0 & 0 & 0 & 0 & 0 & 0 \\
\hline 4 & 0 & 15.04 & 65.41 & 31.36 & 0 & 135.02 & 0 & 28.46 & 23.4 \\
\hline 4 & 0 & 6 & 52.66 & 40.82 & 0 & 76.47 & 5.96 & 7.9 & 59.12 \\
\hline 4 & 0 & 72.7 & 41.12 & 20.82 & 0 & 13.16 & 24.22 & 8.55 & 8.83 \\
\hline 4 & 5.94 & 40.19 & 66.29 & 48.27 & 0 & 30.2 & 68.16 & 25.77 & 0 \\
\hline 4 & 16.64 & 31.88 & 155.17 & 34.4 & 0 & 73.4 & 79.8 & 0 & 0 \\
\hline 4 & 0 & 8.35 & 52.08 & 72.63 & 0 & 5.46 & 13.51 & 42.44 & 0 \\
\hline 4 & 0 & 0 & 40.72 & 126.62 & 0 & 30.46 & 28.14 & 28.88 & 0 \\
\hline 4 & 0 & 17.68 & 21.24 & 81.27 & 0 & 5.74 & 25.98 & 5.97 & 76.54 \\
\hline 4 & 10.3 & 12.76 & 18.17 & 187.41 & 0 & 40.49 & 13.95 & 9.71 & 81.55 \\
\hline 4 & 0 & 55.18 & 33.31 & 35.37 & 0 & 5.21 & 44.58 & 60.2 & 25.9 \\
\hline 4 & 0 & 7.69 & 19.56 & 67.09 & 0 & 0 & 0 & 16.41 & 84.39 \\
\hline 4 & 0 & 68.09 & 27.28 & 27.85 & 14.53 & 9.97 & 58.12 & 6.32 & 0 \\
\hline
\end{tabular}

TC1 indicates tree cluster 1; VC2 indicates vine cluster 2. 
Table 10--continued

\begin{tabular}{|c|c|c|c|c|c|c|c|c|c|}
\hline Zone & $\mathrm{TCl}$ & TC2 & TC3 & $\mathrm{TC4}$ & TC5 & VC2 & VC3 & VC4 & VC5 \\
\hline 4 & 0 & 0 & 42.94 & 31 & 18.46 & 0 & 125.37 & 0 & 150 \\
\hline 4 & 0 & 28.79 & 56.29 & 0 & 0 & 44.81 & 22.4 & 88.65 & 0 \\
\hline 5 & 0 & 0 & 22.97 & 76.73 & 0 & 4.34 & 17.4 & 16.49 & 9.3 \\
\hline 5 & 0 & 0 & 26.84 & 64.91 & 0 & 15.28 & 0 & 10.36 & 51.22 \\
\hline 5 & 0 & 5.81 & 13.86 & 64.23 & 0 & 6.84 & 0 & 14.87 & 73.04 \\
\hline 5 & 0 & 6.02 & 39.94 & 28.87 & 0 & 0 & 39.86 & 9.59 & 155.82 \\
\hline 6 & 0 & 0 & 35.05 & 29.44 & 26.42 & 0 & 0 & 0 & 150 \\
\hline 6 & 0 & 0 & 10.82 & 21.19 & 53.32 & 0 & 0 & 27.3 & 136.35 \\
\hline 6 & 0 & 0 & 35.32 & 33.28 & 0 & 0 & 24.69 & 26.87 & 52.85 \\
\hline 6 & 0 & 5.66 & 5.8 & 71.55 & 0 & 0 & 3.75 & 14.2 & 54.37 \\
\hline 6 & 0 & 4.61 & 26.58 & 50.91 & 0 & 5.3 & 0 & 17.08 & 49.18 \\
\hline 6 & 0 & 0 & 11.79 & 15.8 & 34.58 & 0 & 11.21 & 14.04 & 55.3 \\
\hline 6 & 0 & 0 & 6.06 & 12.3 & 36.91 & 0 & 52.25 & 10.44 & 49.67 \\
\hline 6 & 0 & 16.54 & 0 & 20.22 & 69.98 & 0 & 0 & 0 & 96.96 \\
\hline 6 & 0 & 0 & 0 & 29.17 & 154.4 & 4.35 & 6.12 & 4.35 & 114.03 \\
\hline 6 & 0 & 0 & 0 & 59.44 & 89.43 & 0 & 0 & 0 & 0 \\
\hline 6 & 0 & 0 & 0 & 71.67 & 120.16 & 0 & 0 & 90.37 & 5.84 \\
\hline
\end{tabular}

Table 11

Predicted Hydrologic Zones (Columns) and Actual Zones (Rows) Based on DFA Results Using Only Tree Importance

Values

\begin{tabular}{|c|c|c|c|c|c|c|}
\hline $\begin{array}{c}\text { Actual } \\
\text { Hydrologic }\end{array}$ & & & cte & $\log$ & & \\
\hline Zones & $\underline{2}$ & 3 & 4 & 5 & 6 & Total \\
\hline 2 & 11 & 0 & 0 & 0 & 0 & 11 \\
\hline 3 & 1 & 14 & 0 & 0 & 0 & 15 \\
\hline 4 & 0 & 2 & 10 & 2 & 0 & 14 \\
\hline 5 & 0 & 0 & 0 & 4 & 0 & 4 \\
\hline 6 & $\underline{0}$ & 0 & $\underline{0}$ & 3 & 8 & $\underline{11}$ \\
\hline & $\overline{12}$ & $\overline{16}$ & $\overline{10}$ & $\overline{10}$ & 8 & $\overline{55}$ \\
\hline
\end{tabular}

a Misclassification rate $=14.6$ percent. 
A final model was generated to examine the effectiveness of using the average site FTI numbers of all observed tree species at a site for each of the 55 sites. This model correctly classified 45 of 55 sites for an overall misclassification rate of 18.2 percent (Table 12). All

misclassifications were in an adjacent zone. Zones 2, 3, and 5 were misclassified twice; Zone 4 was misclassified 3 times; and Zone 6 was misclassified only once. Using FTI numbers for all observed tree species improved the results obtained in the first DFA using the importance values of only the commonly occurring species.

In examining the data (Table 13), it appears that three of the misclassifications occur at site 10 (Pearl River, observations 27 to 30 ). The hydrology at this site was obtained from two gauges, and it is

Table 12

Predicted Hydrologic Zones (Columns) and Actual Zones (Rows) Based on DFA Results Using Average FTI Values for All Observed Tree Species at the Site

\begin{tabular}{|c|c|c|c|c|c|c|}
\hline $\begin{array}{l}\text { Actual } \\
\text { Hydrologic }\end{array}$ & & & ted & og & & \\
\hline Zones & 2 & 3 & 4 & $\underline{5}$ & 6 & Total \\
\hline 2 & 9 & 2 & 0 & 0 & 0 & 11 \\
\hline 3 & 0 & 13 & 2 & 0 & 0 & 15 \\
\hline 4 & 0 & 2 & 11 & 1 & 0 & 14 \\
\hline 5 & 0 & 0 & 2 & 2 & 0 & 4 \\
\hline 6 & $\underline{0}$ & 0 & $\underline{0}$ & 1 & $\underline{10}$ & 11 \\
\hline & 9 & 17 & 15 & 4 & 10 & 55 \\
\hline
\end{tabular}

a Misclassification rate $=18.2$ percent. 
Table 13

Cross-Validation Results of Zone Membership Using Linear

Discriminant Function Analysis

\begin{tabular}{|c|c|c|c|c|c|}
\hline \multirow[b]{2}{*}{ Observation } & & & \multicolumn{3}{|c|}{$\begin{array}{c}\text { Posterior Probability of } \\
\text { Membership in Zone: }\end{array}$} \\
\hline & $\begin{array}{l}\text { From } \\
\text { Zone }\end{array}$ & $\begin{array}{l}\text { To } \\
\text { Zone }\end{array}$ & $\begin{array}{l}2 \\
5 \\
\end{array}$ & $\begin{array}{r}3 \\
6 \\
\end{array}$ & 4 \\
\hline \multirow[t]{2}{*}{1} & 2 & 2 & 0.9876 & 0.0124 & 0.0000 \\
\hline & & & 0.0000 & 0.0000 & \\
\hline \multirow[t]{2}{*}{2} & 3 & 3 & 0.1759 & 0.8212 & 0.0029 \\
\hline & & & 0.0000 & 0.0000 & \\
\hline \multirow[t]{2}{*}{3} & 4 & 4 & 0.0000 & 0.0062 & 0.8919 \\
\hline & & & 0.1019 & 0.0001 & \\
\hline \multirow[t]{2}{*}{4} & 6 & 6 & 0.0000 & 0.0000 & 0.0000 \\
\hline & & & 0.0075 & 0.9924 & \\
\hline \multirow[t]{2}{*}{5} & 2 & 2 & 0.9876 & 0.0124 & 0.0000 \\
\hline & & & 0.0000 & 0.0000 & \\
\hline \multirow[t]{2}{*}{6} & 3 & 3 & 0.2436 & 0.7548 & 0.0016 \\
\hline & & & 0.0000 & 0.0000 & \\
\hline \multirow[t]{2}{*}{7} & 4 & 4 & 0.0000 & 0.0376 & 0.9263 \\
\hline & & & 0.0361 & 0.0000 & \\
\hline \multirow[t]{2}{*}{8} & 6 & 6 & 0.0000 & 0.0000 & 0.0000 \\
\hline & & & 0.0007 & 0.9993 & \\
\hline \multirow[t]{2}{*}{9} & 2 & 2 & 0.9801 & 0.0199 & 0.0000 \\
\hline & & & 0.0000 & 0.0000 & \\
\hline \multirow[t]{2}{*}{10} & 3 & 3 & 0.0137 & 0.8865 & 0.0997 \\
\hline & & & 0.0001 & 0.0000 & \\
\hline \multirow[t]{2}{*}{11} & 4 & 4 & 0.0000 & 0.0202 & 0.9273 \\
\hline & & & 0.0526 & 0.0000 & \\
\hline \multirow[t]{2}{*}{12} & 5 & 5 & 0.0000 & 0.0000 & 0.2666 \\
\hline & & & 0.6341 & 0.0993 & \\
\hline \multirow[t]{2}{*}{13} & 6 & 6 & 0.0000 & 0.0000 & 0.0026 \\
\hline & & & 0.0958 & 0.9016 & \\
\hline \multirow[t]{2}{*}{14} & 3 & 3 & 0.1244 & 0.8703 & 0.0052 \\
\hline & & & 0.0000 & 0.0000 & \\
\hline \multirow[t]{2}{*}{15} & 4 & $3^{a}$ & 0.0012 & 0.5429 & 0.4534 \\
\hline & & & 0.0025 & 0.0000 & \\
\hline \multirow[t]{2}{*}{16} & 3 & 3 & 0.0597 & 0.9245 & 0.0158 \\
\hline & & & 0.0000 & 0.0000 & \\
\hline \multirow[t]{2}{*}{17} & 4 & 4 & 0.0003 & 0.2747 & 0.7175 \\
\hline & & & 0.0075 & 0.0000 & \\
\hline \multirow[t]{2}{*}{18} & 3 & 3 & 0.0806 & 0.9092 & 0.0103 \\
\hline & & & 0.0000 & 0.0000 & \\
\hline \multirow[t]{2}{*}{19} & 4 & 4 & 0.0000 & 0.0017 & 0.8069 \\
\hline & & & 0.1909 & 0.0005 & \\
\hline \multirow[t]{2}{*}{20} & 2 & $3^{a}$ & 0.1909 & 0.8079 & 0.0013 \\
\hline & & & 0.0000 & 0.0000 & \\
\hline 21 & 3 & 3 & 0.0748 & 0.9138 & 0.0114 \\
\hline & & & 0.0000 & 0.0000 & \\
\hline
\end{tabular}


Table 13--continued

\begin{tabular}{|c|c|c|c|c|c|}
\hline \multirow[b]{3}{*}{ Observation } & \multirow{3}{*}{$\begin{array}{l}\text { From } \\
\text { Zone }\end{array}$} & \multirow{3}{*}{$\begin{array}{c}\text { To } \\
\text { Zone }\end{array}$} & \multicolumn{3}{|c|}{$\begin{array}{c}\text { Posterior Probability of } \\
\text { Membership in Zone: }\end{array}$} \\
\hline & & & 2 & 3 & \\
\hline & & & 5 & 6 & 4 \\
\hline \multirow[t]{2}{*}{22} & 4 & 4 & 0.0000 & 0.0163 & 0.9242 \\
\hline & & & 0.0594 & 0.0000 & \\
\hline \multirow[t]{2}{*}{23} & 3 & 3 & 0.2436 & 0.7548 & 0.0016 \\
\hline & & & 0.0000 & 0.0000 & \\
\hline \multirow[t]{2}{*}{24} & 4 & 4 & 0.0008 & 0.4558 & 0.5398 \\
\hline & & & 0.0036 & 0.0000 & \\
\hline \multirow[t]{2}{*}{25} & 3 & 3 & 0.0150 & 0.8945 & 0.0904 \\
\hline & & & 0.0001 & 0.0000 & \\
\hline \multirow[t]{2}{*}{26} & 6 & 6 & 0.0000 & 0.0000 & 0.0000 \\
\hline & & & 0.0002 & 0.9998 & \\
\hline \multirow[t]{2}{*}{27} & 2 & $3^{a}$ & 0.0205 & 0.9672 & 0.0124 \\
\hline & & & 0.0000 & 0.0000 & \\
\hline \multirow[t]{2}{*}{28} & 3 & $4^{a}$ & 0.0011 & 0.4321 & 0.5641 \\
\hline & & & 0.0027 & 0.0000 & \\
\hline \multirow[t]{2}{*}{29} & 4 & 4 & 0.0000 & 0.0039 & 0.8673 \\
\hline & & & 0.1286 & 0.0002 & \\
\hline \multirow[t]{2}{*}{30} & 6 & $5^{a}$ & 0.0000 & 0.0000 & 0.3649 \\
\hline & & & 0.6307 & 0.0044 & \\
\hline \multirow[t]{2}{*}{31} & 2 & 2 & 0.8970 & 0.1030 & 0.0000 \\
\hline & & & 0.0000 & 0.0000 & \\
\hline \multirow[t]{2}{*}{32} & 3 & 3 & 0.3105 & 0.6886 & 0.0009 \\
\hline & & & 0.0000 & 0.0000 & \\
\hline \multirow[t]{2}{*}{33} & 4 & 4 & 0.0000 & 0.0202 & 0.9273 \\
\hline & & & 0.0526 & 0.0000 & \\
\hline \multirow[t]{2}{*}{34} & 5 & $4^{\mathrm{a}}$ & 0.0000 & 0.0003 & 0.6274 \\
\hline & & & 0.3664 & 0.0060 & \\
\hline \multirow[t]{2}{*}{35} & 4 & $3^{a}$ & 0.0014 & 0.5719 & 0.4246 \\
\hline & & & 0.0021 & 0.0000 & \\
\hline \multirow[t]{2}{*}{36} & 5 & $4^{a}$ & 0.0000 & 0.0001 & 0.5378 \\
\hline & & & 0.4502 & 0.0119 & \\
\hline \multirow[t]{2}{*}{37} & 6 & 6 & 0.0000 & 0.0000 & 0.0019 \\
\hline & & & 0.0785 & 0.9196 & \\
\hline \multirow[t]{2}{*}{38} & 2 & 2 & 0.9503 & 0.0497 & 0.0000 \\
\hline & & & 0.0000 & 0.0000 & \\
\hline \multirow[t]{2}{*}{39} & 3 & 3 & 0.2436 & 0.7548 & 0.0016 \\
\hline & & & 0.0000 & 0.0000 & \\
\hline 40 & 4 & 4 & 0.0000 & 0.0002 & 0.5894 \\
\hline & & & 0.4057 & 0.0047 & \\
\hline 41 & 6 & 6 & 0.0000 & 0.0000 & 0.0000 \\
\hline & & & 0.0013 & 0.9987 & \\
\hline 42 & 2 & 2 & 0.9332 & 0.0668 & 0.0000 \\
\hline & & & 0.0000 & 0.0000 & \\
\hline 43 & 5 & 5 & 0.0000 & 0.0000 & 0.3085 \\
\hline & & & 0.6216 & 0.0699 & \\
\hline 44 & 6 & 6 & 0.0000 & 0.0000 & 0.0000 \\
\hline & & & 0.0013 & 0.9987 & \\
\hline
\end{tabular}


Table 13 --continued

\begin{tabular}{|c|c|c|c|c|c|}
\hline \multirow[b]{2}{*}{ Observation } & \multirow[b]{2}{*}{$\begin{array}{l}\text { From } \\
\text { Zone }\end{array}$} & \multirow[b]{2}{*}{$\begin{array}{c}\text { To } \\
\text { Zone }\end{array}$} & \multicolumn{3}{|c|}{$\begin{array}{c}\text { Posterior Probability of } \\
\text { Membership in Zone: }\end{array}$} \\
\hline & & & $\begin{array}{l}2 \\
5 \\
\end{array}$ & $\begin{array}{r}3 \\
6 \\
\end{array}$ & 4 \\
\hline \multirow[t]{2}{*}{45} & 2 & 2 & 0.9503 & 0.0497 & 0.0000 \\
\hline & & & 0.0000 & 0.0000 & \\
\hline \multirow[t]{2}{*}{46} & 3 & $4^{a}$ & 0.0001 & 0.1163 & 0.8743 \\
\hline & & & 0.0093 & 0.0000 & \\
\hline \multirow[t]{2}{*}{47} & 6 & 6 & 0.0000 & 0.0000 & 0.0000 \\
\hline & & & 0.0015 & 0.9985 & \\
\hline \multirow[t]{2}{*}{48} & 2 & 2 & 0.8729 & 0.1271 & 0.0000 \\
\hline & & & 0.0000 & 0.0000 & \\
\hline \multirow[t]{2}{*}{49} & 3 & 3 & 0.2144 & 0.7835 & 0.0020 \\
\hline & & & 0.0000 & 0.0000 & \\
\hline \multirow[t]{2}{*}{50} & 4 & 4 & 0.0000 & 0.0020 & 0.8170 \\
\hline & & & 0.1806 & 0.0005 & \\
\hline \multirow[t]{2}{*}{51} & 6 & 6 & 0.0000 & 0.0000 & 0.0000 \\
\hline & & & 0.0011 & 0.9989 & \\
\hline \multirow[t]{2}{*}{52} & 2 & 2 & 0.7969 & 0.2031 & 0.0000 \\
\hline & & & 0.0000 & 0.0000 & \\
\hline \multirow[t]{2}{*}{53} & 3 & 3 & 0.1004 & 0.8923 & 0.0074 \\
\hline & & & 0.0000 & 0.0000 & \\
\hline \multirow[t]{2}{*}{54} & 4 & $5^{a}$ & 0.0000 & 0.0000 & 0.1753 \\
\hline & & & 0.7509 & 0.0739 & \\
\hline \multirow[t]{2}{*}{55} & 6 & 6 & 0.0000 & 0.0000 & 0.0000 \\
\hline & & & 0.0020 & 0.9980 & \\
\hline
\end{tabular}

a Miclassified observation. 
possible that an error was made in combining the hydrologic data from the two gauges. It seems ironic that the only zone correctly predicted at this site was Zone 4. Table 13 also shows the percentage probability of each of the 55 sites occurring in a zone.

Figure 11 shows the mean site FTI plotted against the observed and predicted hydrologic zones. As expected, mean FTI numbers were greater than the observed hydrologic zones at the low end (Zone 2) and less than the zones at the upper end (Zone 6) of the hydrologic gradiant due to the lack of outlying zones (e.g., Zones 1 and 7) to pull these averages toward either extreme. Therefore, using DFA classification decision points shows that average site FTI numbers as high as 3.45 would still be in Zone 2, and average site FTI numbers as low as 5.33 would still be in Zone 6. The lower end of the predicted Zone 4 (4.16) compares favorably with the observed (4.0). Zone 5 predicted and observed zone values are the same $(5.0)$.

\section{Regional Variation in Species FTI Numbers}

Because the 17 sites in this study occur over a broad geographic area, the possibility of regional differences in species FTI numbers was a concern. To test for possible differences, the sites were grouped into three regions: Gulf Coast (sites 1, 2, 10, 11, 12), Mississippi Valley (sites 3 through 9), and Atlantic Coast (sites 13 through 17).

A two-factor analysis of variance (ANOVA) was used to test for differences in importance values between regions and clusters for trees. There was no significant interaction between region and cluster trees $(F=0.71, p=0.68)$; therefore, importance values of species within a cluster do not differ among regions. There was a significant difference 


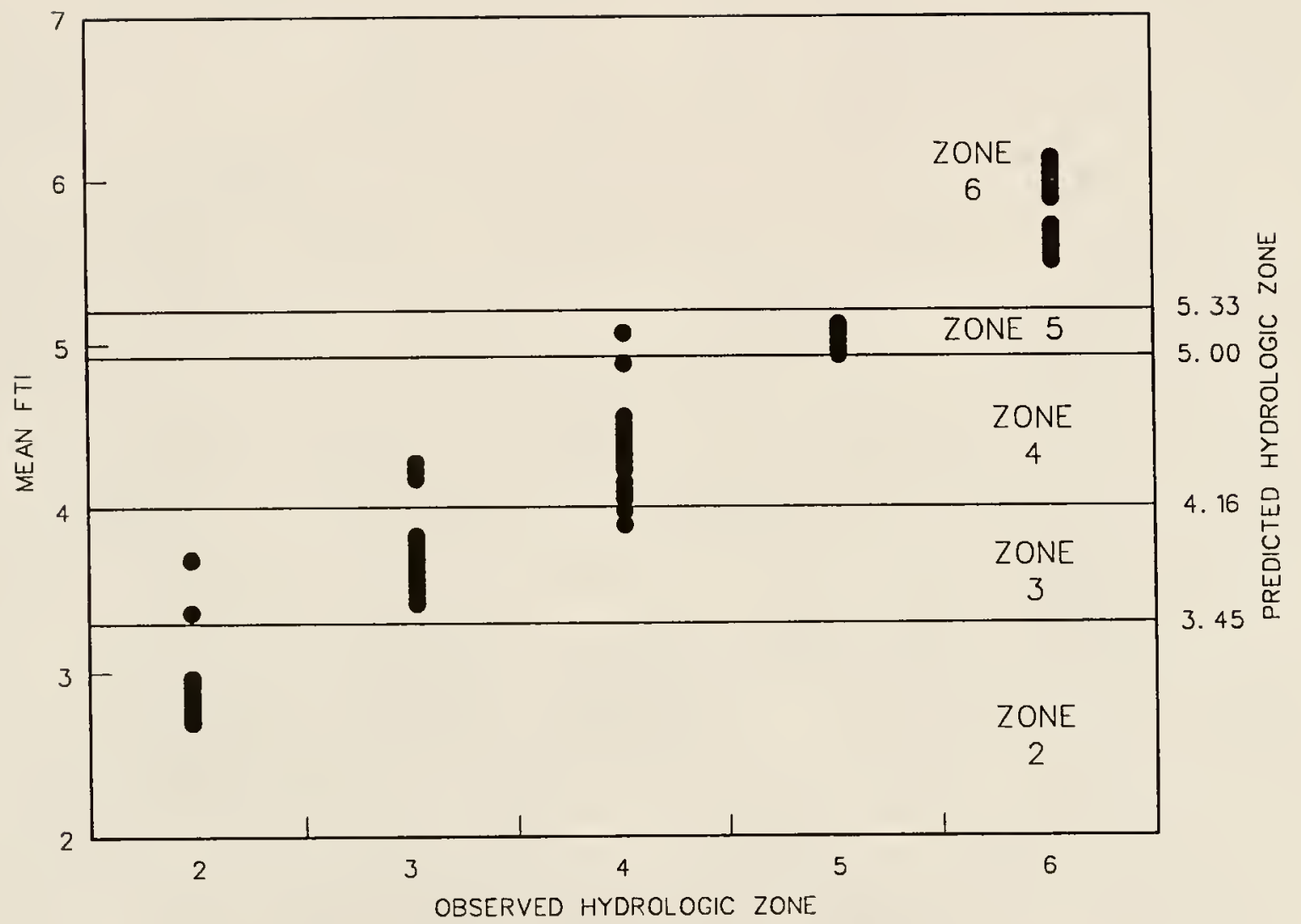

Figure 11. Mean tree FTI numbers plotted versus observed and predicted hydrologic zones for all 55 sites 
between regions $(F=4.02, P=0.019)$, reflecting the fact that importance values of trees were greater in the Mississippi Valley, averaging $49.1 \pm 47.6$, than the Gulf Coast $(37.5 \pm 37.2)$ and Atlantic Coast $(39.3 \pm 34.4)$ regions. A number of factors may contribute to this phenomenon, including stand maturity and localized disturbances. Another two-factor ANOVA also was used to determine whether the predicted zone values generated were more accurate in one region or another. The absolute value of the difference between the predicted and actual zones was used as the dependent variable. There was neither an interaction $(F=1.44, p=0.18)$, nor a main effect $(F=1.54, p=0.22)$ involving region, which indicates that the hydrologic zones can be predicted with equal accuracy among the specified regions. 
SUMMARY AND CONCLUSIONS

Bottomland hardwood forests are dynamic and complex systems. Frequent flooding from adjacent streams provides the forcing function that characterizes the affected plant communities. Frequency and duration of floodwater determine the extent of anaerobic soil conditions that directly affect plant populations. Plant species adapted for life in anerobic soil conditions are located in the topographically lowest areas subject to long duration flooding. Species composition changes as the elevational and associated moisture gradient changes from wettest to driest, and reflects species adaptations to the prevailing hydrologic regimes.

Determination of a hydrologic gradient often requires extensive data gathering over a long period. However, many studies have shown that a definite relationship exists between plant species and the timing, frequency, and duration of inundation and soil saturation (Larson et a1. 1981). This study was undertaken to express quantitatively the optimum position of various plant species along a hydrologic gradient. Previous studies have estimated the location of plant species and communities along a hydrologic gradient. Various systems have been proposed that use vegetation to predict the duration and/or frequency of flooding. However, previous studies were limited to a small geographic area, the developed systems are qualitative, and vegetation data used to 
predict the degree of flooding for the entire southeastern United States previously have been literature-based involving many studies with varying research designs.

Vegetation data resulting from this study related four vegetation strata and three life forms occurring in 55 stands at 17 sites throughout the southeastern United States. Hydrologic regimes were calculated for a 10- to 20-year period of record for each stand. A flood tolerance index (FTI) system of weighted averages based on importance values was developed, and FTI numbers were calculated for various life stages of each species identified in the study.

Three hundred and twelve species were identified for each of 4 strata in the study including 74 tree species, 188 species of saplings and shrubs, 31 species of woody vines, and 268 species of herbs and woody seedlings. Comparison of the FTI numbers with two other systems (Hook 1984; Reed 1988) using vegetation to estimate wetness showed general agreement among the systems, especially for mature trees.

Cluster analysis and discriminant function analysis were used to evaluate the weighted averaging technique and explore the best method for using the FTI numbers in predicting hydrologic regimes.

Tree, sapling, and vine data clustered into distinct groups. Herbaceous and shrub data did not group distinctively. Tree and vine importance values for each cluster in a zone/sample (data taken in a single zone at a site) and FTI numbers for tree data were used as independent variables for the discriminant function analyses. Tree species were found to be more useful than saplings, shrubs, vines, or herbaceous species in predicting hydrologic zones. The tree data alone using importance values provided 85 percent accuracy. Tree data alone using 
FTI numbers was only slightly less accurate at 82 percent. All misclassifications assigned membership to a neighboring zone. Misclassifications are understandable for two important reasons. Zone 4 contains the more facultative species because as wetness decreases, other environmental conditions begin to exert greater influence. Also, since Zone 5 is so narrow compared to other zones and most species occurring in Zone 5 occur in greater abundance in either zone 4 or 6 , very little difference in the community structure exists between the top of Zone 4 and the bottom of Zone 6 .

The accuracy of these predictions may be somewhat inflated, because hydrologic zone was a parameter used to derive species FTI numbers.

There were no regional (Gulf Coast, Lower Mississippi Valley, and Atlantic Coast) differences in the accuracy of the weighted averaging and predicted values. Therefore, a single FTI number calculated for each species can be used to predict zones for the entire study area.

The implication of this study is that the calculated FTI numbers can be used to estimate hydrologic regimes in bottomland forest systems of the southeastern United States. Trees were determined to be the most reliable vegetative growth form for determining hydrologic zones. However, this study was conducted in relatively undisturbed areas. Because trees can remain for decades following hydrologic disturbance, a modification of the method using saplings and seedlings may prove to be more reliable.

Techniques used in this study to develop FTI numbers in the southeastern United States may be applicable to regions of the country that have similar types of riverine forest systems. 
APPENDIX A

SITE DESCRIPTIONS AND MAP LOCATIONS 
Neches River (Sites 1 and 2)

Location (Neches River Basin) - These sites are located in the National Big Thicket Preserve, Jack Gore Baygall unit, $6.4 \mathrm{~km}$ north of Evadale in Jasper County, Texas. Reference U.S. Geological Survey (USGS) map, Silsbee, Texas, N3015-W9400/15, 1955.

Hydrology data - Twenty years of hydrology data were obtained for a staff gauge on U.S. Highway 96 bridge at Evadale. Slope correction from gauge datum to study site was determined by using a water surface profile.

General vegetation - Plant communities range from Taxodium distichumNyssa aquatica in deep sloughs to Quercus alba-Pinus taeda and Fagus grandifolia on the nearby ridges. Intermediate communities consist of Quercus lyrata, Carya aquatica, Quercus michauxii, Liquidambar styraciflua, Ulmus americana, and Carpinus caroliniana.

Soils and climate - Soils vary from the very poorly drained Angelina series in sloughs to the moderately well drained Spruger series on ridges. Other soil series encountered were Bleakwood, Urbo, and Attoyac. Average annual rainfall in the area is $170 \mathrm{~cm}$, and the average growing season is 234 days.

Delineated zones - Zones 2, 3, 4, and 6 were delineated for both sites. Zone 5 was too narrow to reliably delineate due to its position on the slope of the floodplain terrace. 


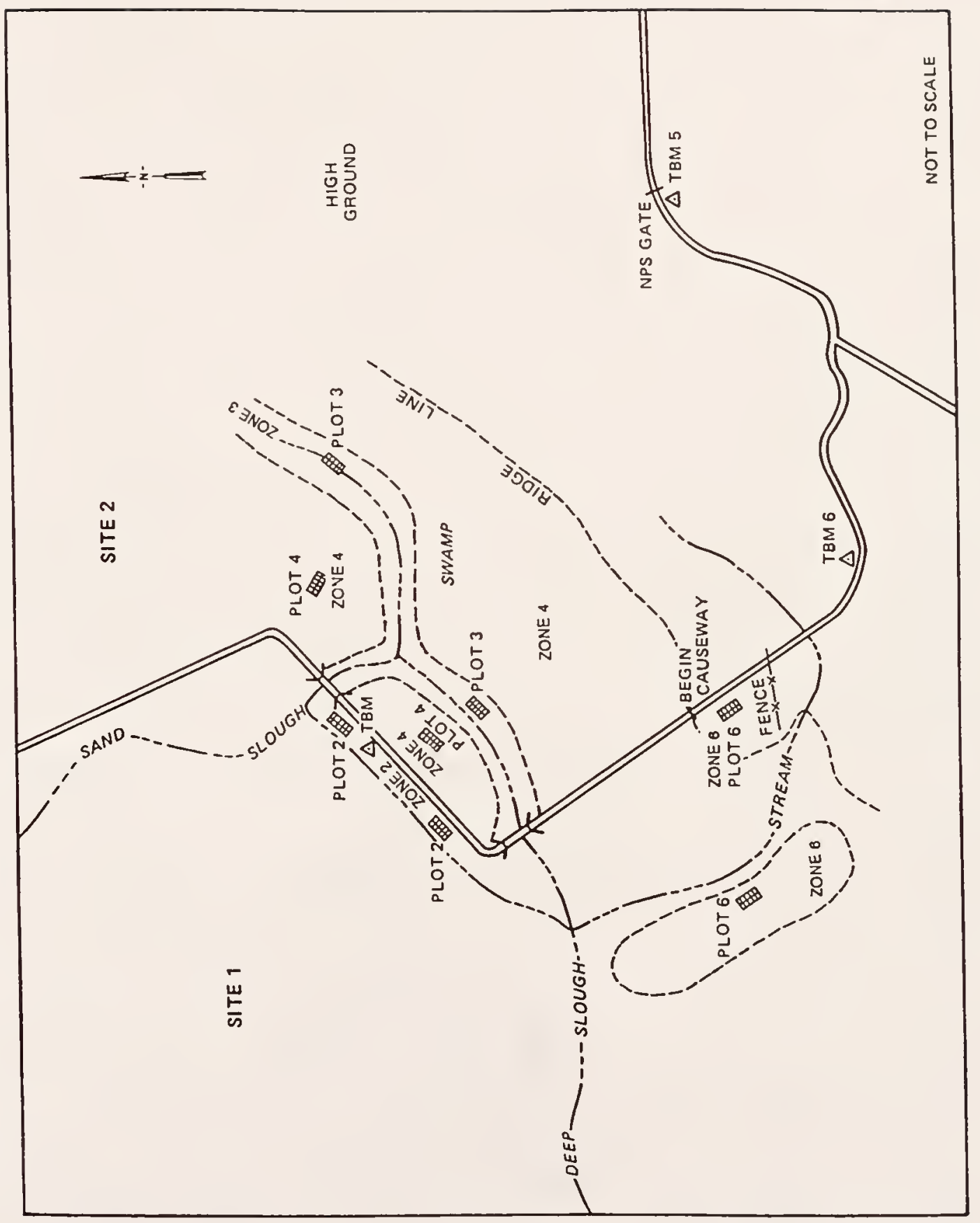

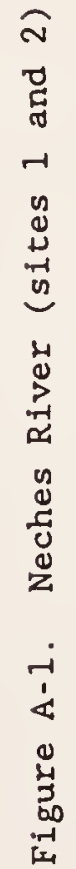


Steele Bayou (Site 3)

Location (Yazoo River Basin) - This site is located in the Yazoo National Wildlife Refuge, $6.4 \mathrm{~km}$ northeast of Glen Allen in Washington County, Mississippi. Reference USGS map, Percy, Mississippi, N3300W9052.5/7.5, 1967 .

Hydrology data - Twenty years of hydrology data were obtained for a gauge on the bridge over Steele Bayou $6.4 \mathrm{~km}$ south of Grace, Mississippi. Slope correction from gauge datum to study site was determined by a water surface profile.

General vegetation - Plant communities ranged from a Salix nigraTaxodium distichum community at lower elevations to a Sassafrass albidum-Liquidambar styraciflua-Quercus nigra community at the highest elevation. Intermediate communities are dominated by Planera aquatica, Forestiera acuminata, Quercus lyrata, Carya aquatica, Fraxinus pennsylvanica, Celtis laevigata, Acer negundo, and Ulmus americana.

Soils and climate - Soil series range from Sharkey at the lowest elevations to Dundee at the higher elevations. Average annual rainfall in the area is $132 \mathrm{~cm}$ and the average growing season is 213 days.

Delineated zones - Zones 2 through 6 were delineated for study at this site. 


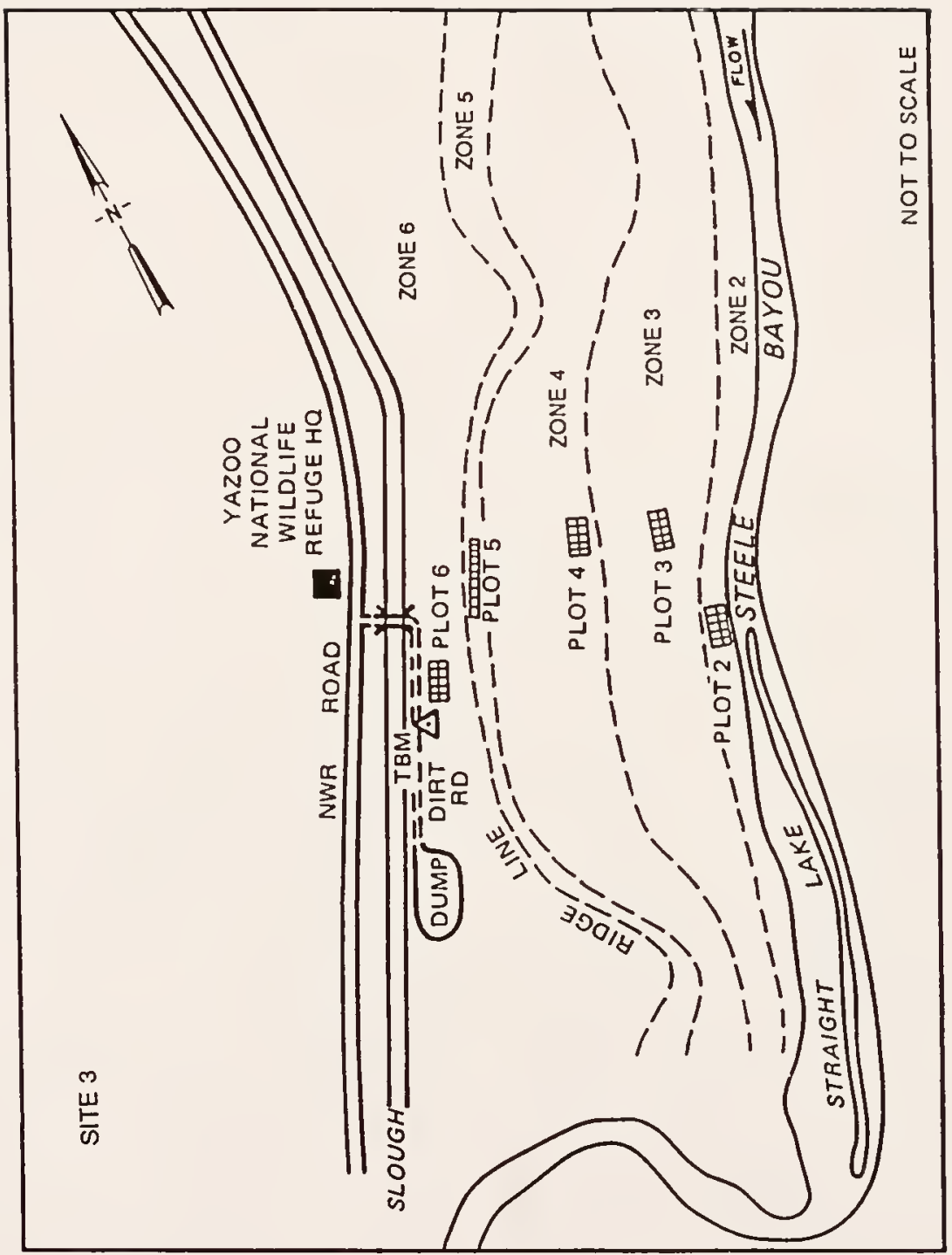

ڤె 
Ouachita River (Sites 4 and 5 )

Location (Ouachita River Basin) - These sites are located in the Felsenthal National Wildlife Refuge, $8 \mathrm{~km}$ west of Crossett and $.8 \mathrm{~km}$ east of Felsenthal, respectively, in Union County, Arkansas. Reference USGS map, Felsentha1, Arkansas-Louisiana, N3300-W9200/15, 1981.

Hydrology data - Nineteen years of hydrology data were obtained for a gauge on a U.S. Highway 81 bridge, $8 \mathrm{~km}$ west of Crossett, Arkansas. A slope correction for site 5 was determined using a water surface profile. Site 4 was adjacent to the gauge, so no correction was necessary.

General vegetation - Plant communities range from a Taxodium distichumCephalanthus occidentalis dominated community in lower areas to a nearly monotypic stand of $P$ inus taeda in higher areas. Intermediate communities are dominated Carya aquatica, Quercus lyrata, Diospyros virginiana, Quercus phellos, Quercus nuttallii, and Liquidambar styraciflua.

Soils and climate - All encountered soils are in the Una series. Average annual rainfall is $140 \mathrm{~cm}$ and the average growing season is 211 days.

Delineated zones - Only Zones 3 and 4 were delineated for both sites 4 and 5 . Zone 2 was not used because the hydrology was not reflected by the gauge data. Zones 5 and 6 were not used due to major disturbances from recent silvicultural and agricultural practices. 


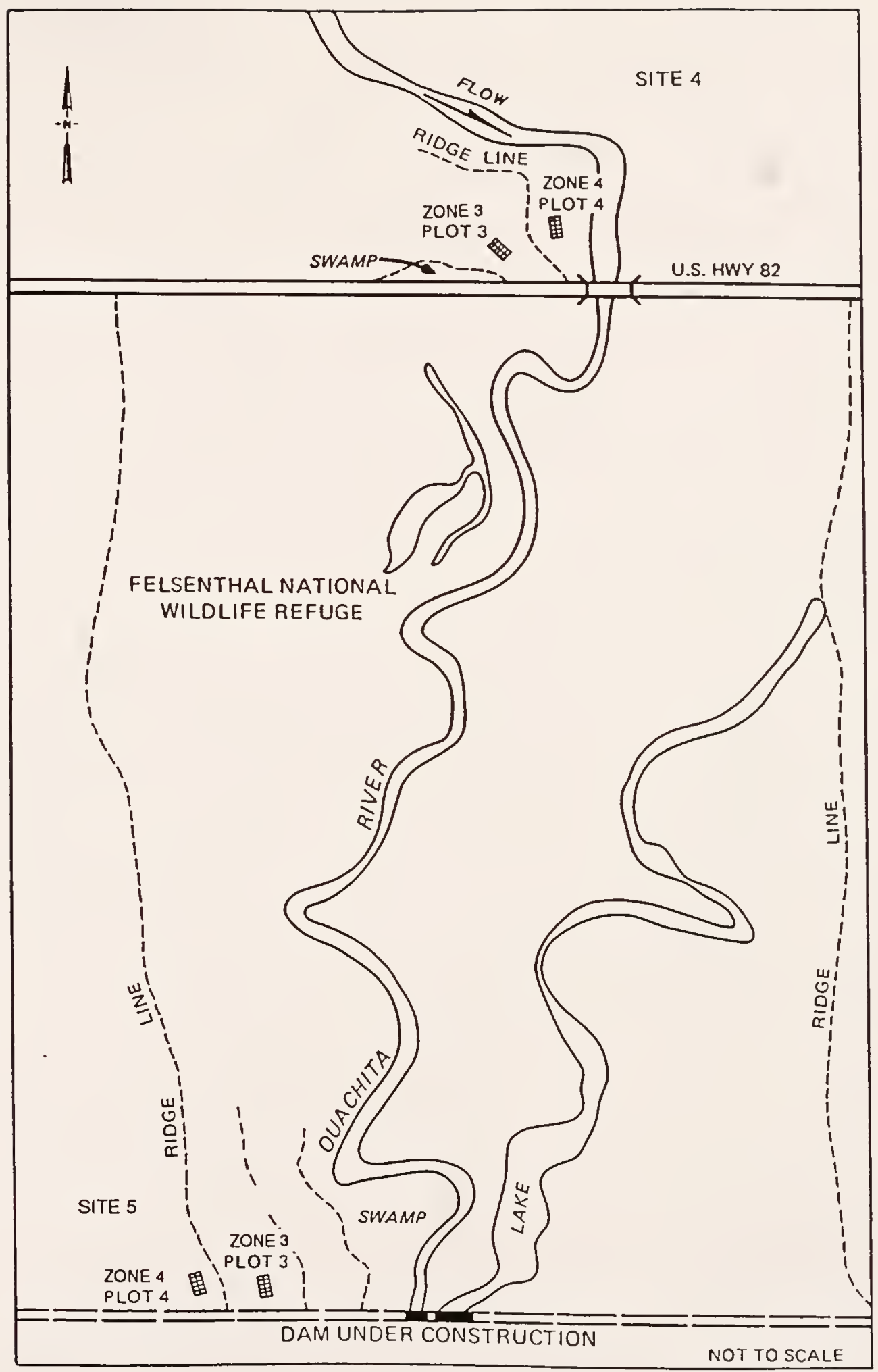

Figure A-3. Ouachita River (sites 4 and 5) 
Yazoo River (Site 6)

Location (Yazoo River Basin) - This site is located on the north side of the Yazoo River, $8 \mathrm{~km}$ west of the U.S. Highway 61 bridge and 12.0 miles north of Vicksburg, Mississippi in Issaquena County. Reference USGS map, Long Lake, Mississippi-Louisiana, N3222.5-W9052.5/7.5, 1962.

Hydrology data - Twenty years of hydrologic zone elevations were computed by analyzing flow data from gauges on the Mississippi River at Vicksburg, Mississippi, on the Yazoo River $2.4 \mathrm{~km}$ east of the site, and at the Steele Bayou control structure immediately adjacent to the study site.

General vegetation - Plant communities range from Quercus lyrata-Carya aquatica at lowest elevations to a Liquidambar styraciflua-Ulmus americana-Celtis laevigata association at the highest elevations. Other commonly occurring species include Ilex decidua, Carya illinoensis, and Cercis canadensis.

Soils and climate - Soils were determined to be in the Sharkey series. Average annual rainfall is $127 \mathrm{~cm}$. The average growing season is 221 days.

Delineated zones for study - Only Zones 3 and 4 were delineated for this study. Zones 2, 5, and 6 were either too narrow or too disturbed to provide reliable data. 


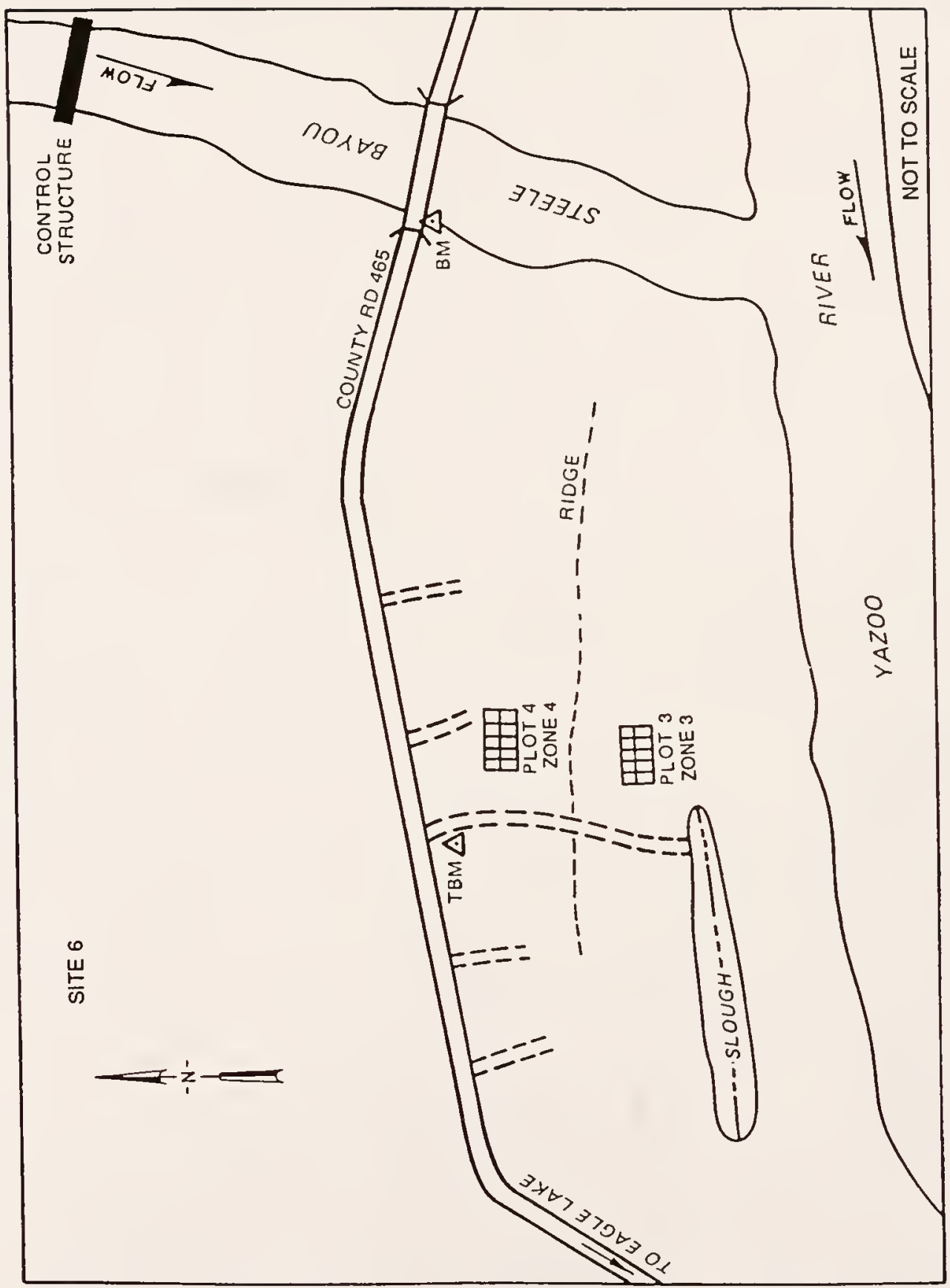

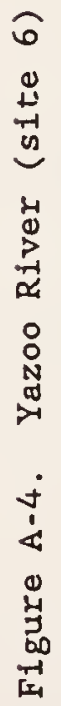


Big Black River (Site 7)

Location (Big Black River Basin) - The site is located on the south bank of the Big Black River adjacent to the Fisher Ferry bridge on Fisher Ferry Road, $24 \mathrm{~km}$ south-southeast of Vicksburg, Mississippi. The site is in Claiborne County, Mississippi. References USGS map, name N3207.5W9045/7.5, 1963.

Hydrology data - Twenty years of hydrologic data were analyzed for a flow gauge on the U.S. Highway 80 bridge, $3.7 \mathrm{~km}$ east of Bovina, Mississippi. A slope correction from gauge location to site was determined by a water surface profile.

General vegetation - Plant communities range from Taxodium distichumNyssa aquatica at lower elevations to Liquidambar styraciflua-Celtis laevigata-Ulmus americana at higher elevations. Intermediate communities are dominated by Planera aquatica, Carya aquatica, Quercus Iyrata, and Fraxinus pennsylvanica.

Soils and climate - Soils range from the Waverly series (depressional phase) in lowest elevations to the Faylaya series at higher elevations. Average annual rainfall for this area is $132 \mathrm{~cm}$ and the average growing season is 226 days.

Delineated zones - Zones 2, 3, and 4 were delineated for study. Zones 5 and 6 were not delineated due to major vegetation disturbance induced by silvicultural and agricultural practices. 


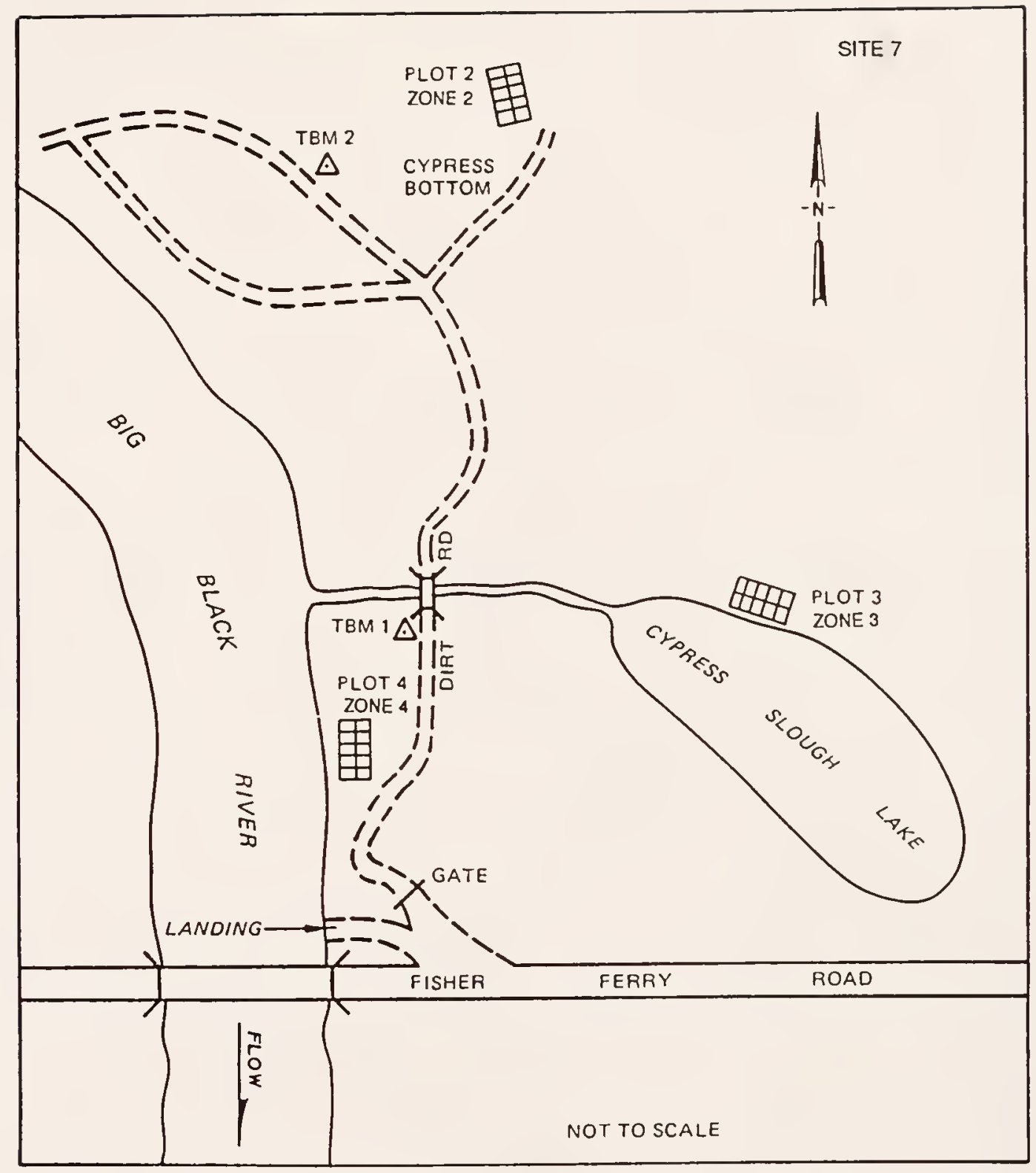

Figure A-5. Big Black River (site 7) 


\section{L'Anguille River (Sites 8 and 9)}

Location (L'Anguille River Basin) - Sites 8 and 9 are located on the west bank of L'Anguille River, $0.8 \mathrm{~km}$ east and $7.2 \mathrm{~km}$ southeast, respectively, of Palestine in St. Francis County, Arkansas. Reference USGS map, Marianna, Arkansas, N3445-W9045/15, 1957.

Hydrology data - Twenty years of hydrologic data were analyzed for a gauge located on the U.S. Highway 70 bridge, $0.8 \mathrm{~km}$ east of Palestine, Arkansas. A slope correction was computed for site 9 using a water surface profile. No slope correction was necessary for site 8 because it was adjacent to the gauge.

General vegetation - Plant communities range from Taxodium distichumNyssa aquatica dominated communities at the lowest elevations to a Carya tomentosa-Quercus alba-Liquidambar styraciflua dominated association on adjacent ridges. Intermediate communities are dominated by Quercus lyrata, Carya aquatica, Diospyros virginiana, Fraxinus pennsylvanica, and Ulmus americana.

Soils and climate - Soil series range from Zachary at lower elevations to Loring on adjacent ridges. Average annual rainfall is $132 \mathrm{~cm}$, and the average growing season is 219 days.

Delineated zones - Zones 3 and 4 were delineated for sites 8 . Zones 3 and 6 were delineated for site 9 . All other zones were unacceptable. 


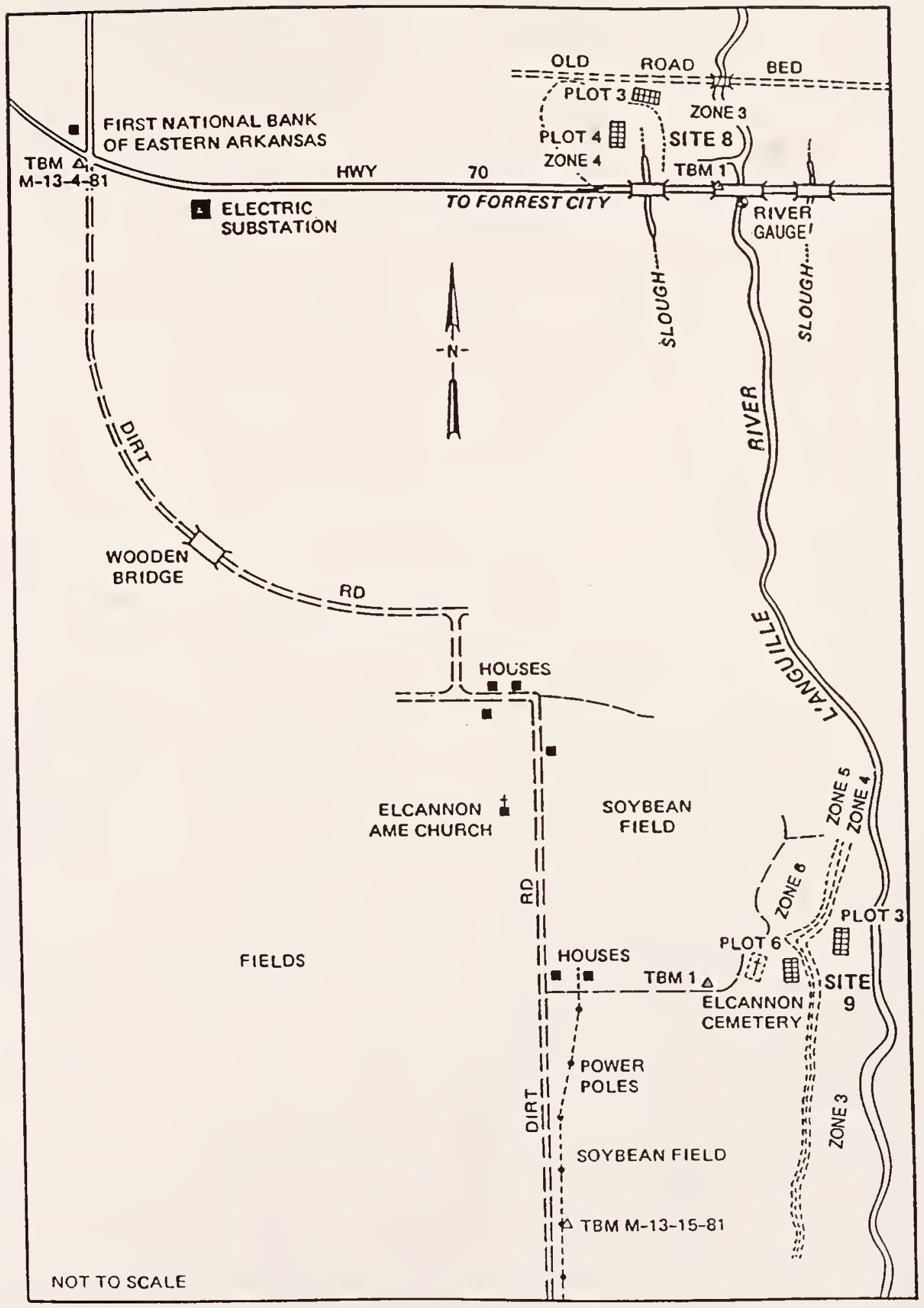

Figure A-6. L'Anguille River (sites 8 and 9) 


\section{Pearl River (Site 10 )}

Location (Pearl River Basin) - This site is located in the Pearl River State Wildlife Management Area, $8 \mathrm{~km}$ north of Slidell in St. Tammany Parish, Louisiana. Reference USGS map Nicholson, Mississippi-Louisiana, N3022.5-W8937.5/7.5, 1955.

Hydrology data - Twenty years of hydrology data were analyzed for two gauges. First 10 years data was extrapolated to present gauge on the Southern Railway bridge at Pearl River, Louisiana. No slope correction was necessary because the site is adjacent to the gauge.

General vegetation - Plant communities range from Taxodium distichumNyssa aquatica dominated communities in sloughs to Liquidambar styraciflua-Quercus nigra dominated communities on low ridges. Intermediate communities are dominated by Quercus laurifolia, Acer drummondii, Fraxinus pennsylvanica, Carpinus caroliniana, and Ilex opaca.

Soils and climate - Soil series range from Rosebloom (depressional phase) in sloughs to Prentiss on ridges with Arkabutla at intermediate elevations. Average annual rainfall is $152 \mathrm{~cm}$, and the average growing season is 237 days.

Delineated zones - Zones 2, 3, 4, and 6 were delineated. Zone 5 could not be reliably delineated due to topography. 


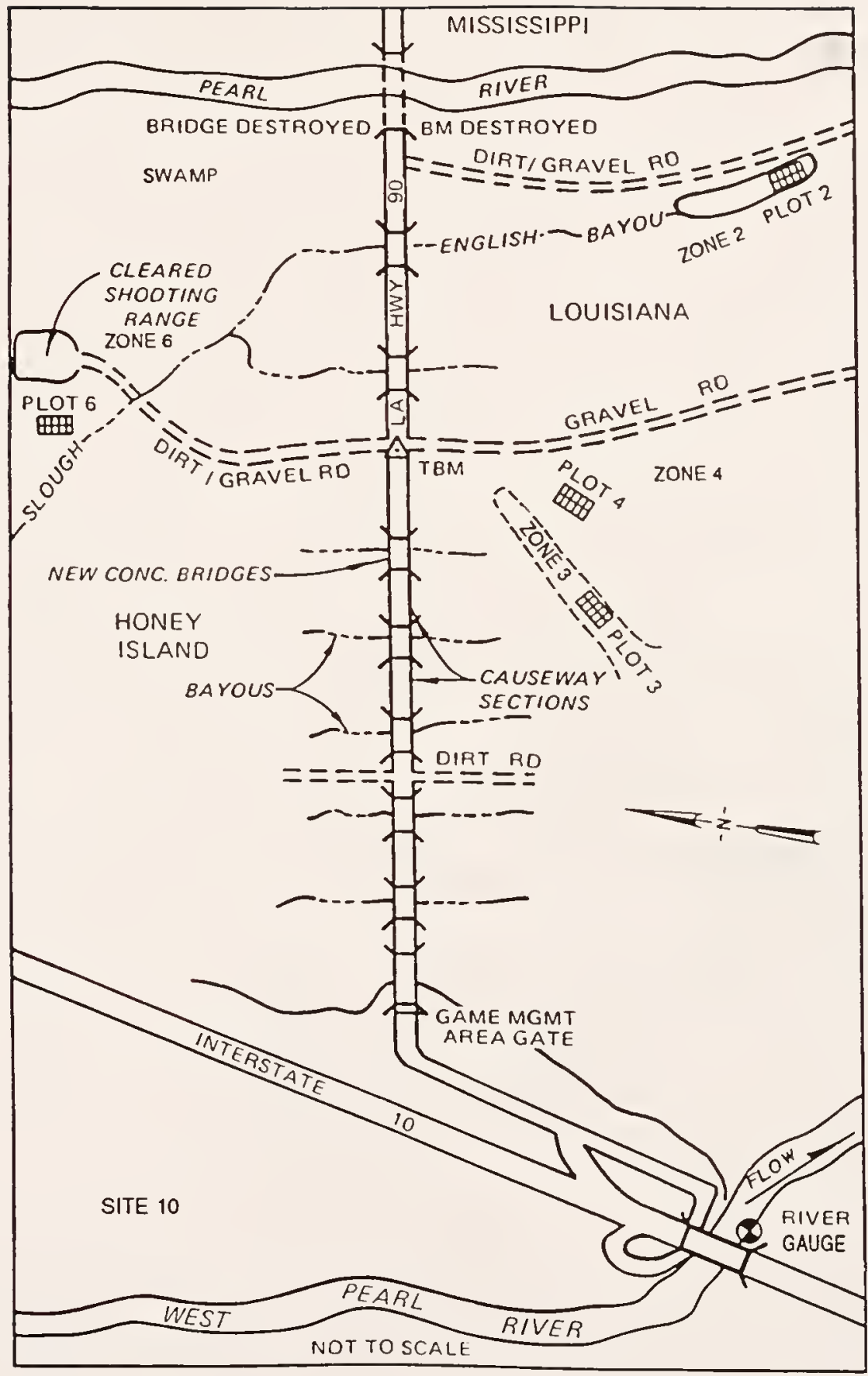

Figure A-7. Pearl River (site 10) 
Location - Site 11 is located on the west bank of the Apalachicola River, immediately south of the Florida Highway 20 bridge, $1.6 \mathrm{~km}$ east of Blountstown in Calhoun County, Florida. Site 12 is located on the east bank of the river, $4.8 \mathrm{~km}$ north of Bristol in Liberty County, Florida. Reference USGS maps Blountstown, Florida, N3022.5-W8500/7.5, 1945, and Bristol, Florida, N3022.5-W8452.5/7.5, 1945, respectively.

Hydrology data - Twenty years of hydrology data for Site 11 were analyzed for a gauge located $0.8 \mathrm{~km}$ south of Highway 20 bridge at the Neal Lumber Company Landing. Hydrology data for Site 12 were analyzed from data from a previous study (Leitman et al. 1984).

General vegetation - Vegetation for both sites ranges from Nyssa aquatica--dominated swamps at lower elevations to Nyssa sylvaticaJuglans nigra-Sassafras albidum dominated associations at higher elevations. Intermediate plant communities consist of Fraxinus caroliniana, Gleditsia aquatica, Quercus lyrata, Carya aquatica, Ulmus americana, Melia azederach, Celtis laevigata, and Quercus nigra.

Soils and climate - Soil series range from Bibb at lower elevation to Ochlochonee at higher elevations. Soils series occurring at intermediate elevations were Chastain, Enoree, Jena, and Chewacla. Average annual rainfall is $137 \mathrm{~cm}$, and the average growing season is 267 days.

Delineated zones - Zones delineated for site 11 were 2, 3, 4, and 5 . Essentially all of Zone 6 has been developed for agriculture. Zones delineated for site 12 were 4,5, and 6 . The hydrology of Zones 2 and 3 had been altered by an extensive network of beaver dams and was not reliable. 


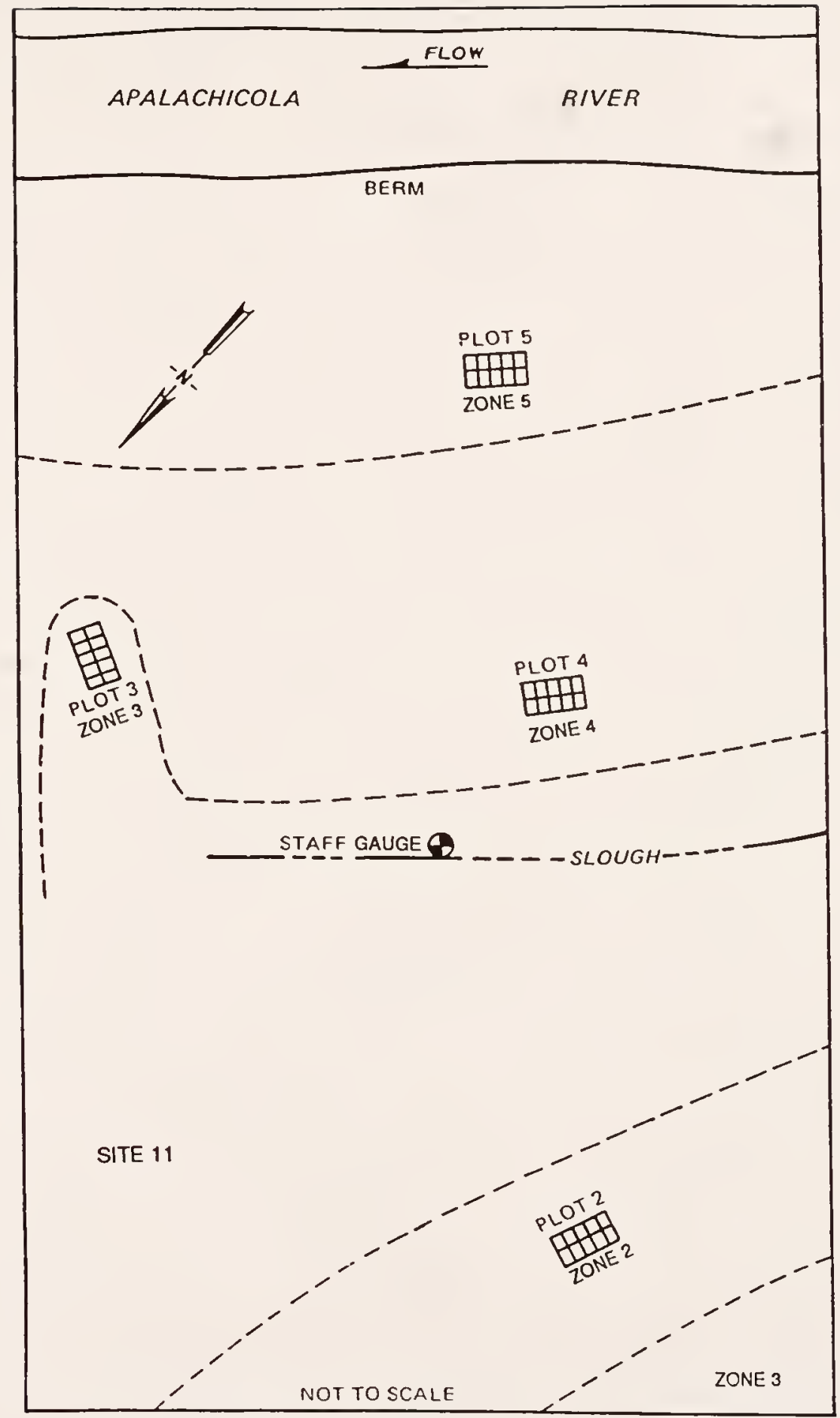

Figure A-8. Apalachicola River (site 11) 


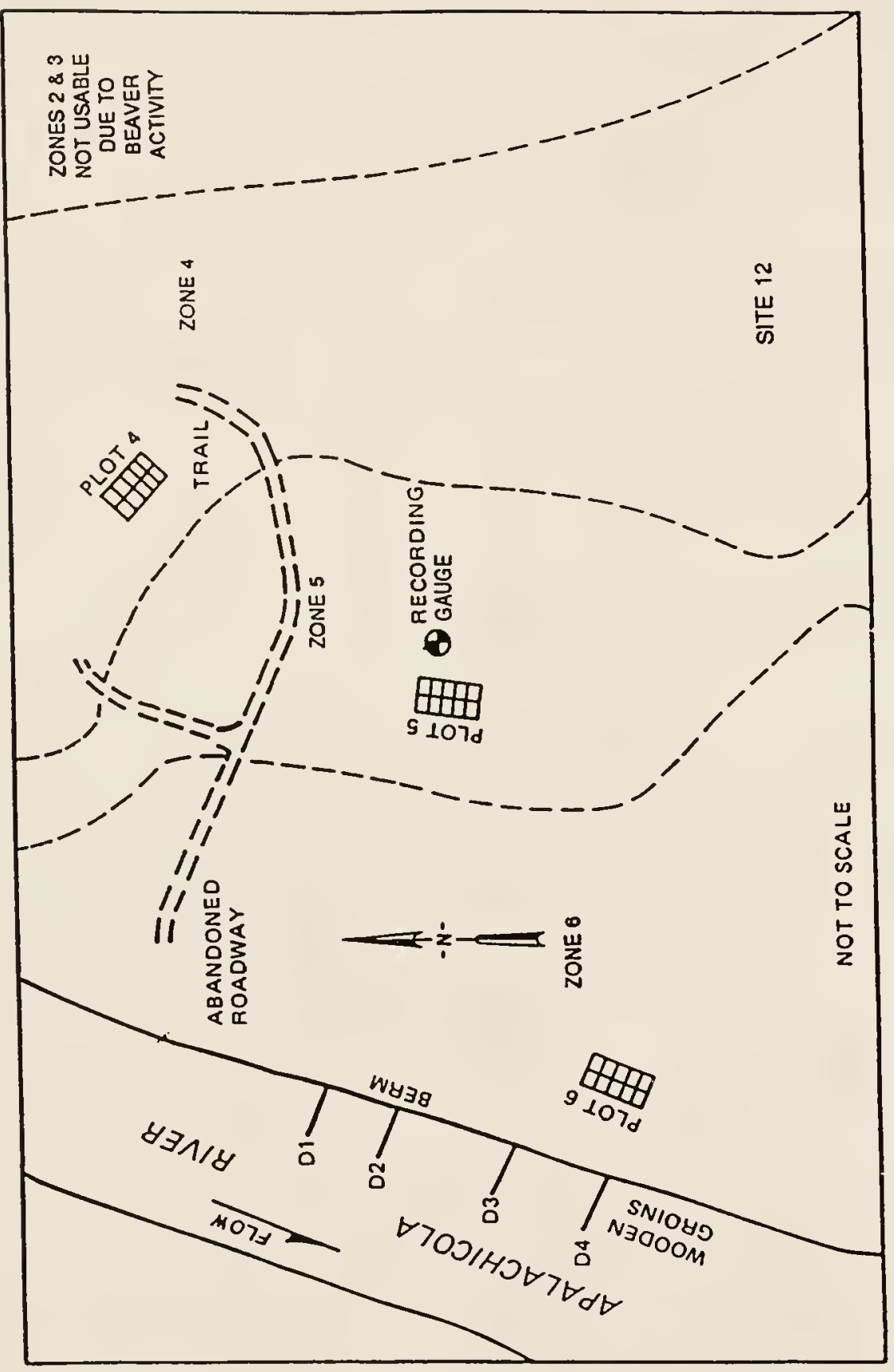

年 
Ocmulgee River (Site 13)

Location (Ocmulgee River Basin) - This site is located across the river from Lumber City, and adjacent to the east side of Southern Railway and U.S. Highway 23 and 341 in Jeff Davis County, Georgia. Reference USGS map, Lumber City, Georgia, N3152.5-W8237.5/7.5, 1971.

Hydrology data - Twenty years of hydrology data were analyzed for a gauge on the U.S. Highway 23 and 341 bridge adjacent to the site. No slope correction was necessary.

General vegetation - The plant communities range from Taxodium distichum-Nyssa aquatica communities at the lowest elevations to a Carya tomentosa-Quercus alba-Pinus glabra dominated association at the higher elevations. Intermediate commities consist of Planera aquatica, Quercus lyrata, Carya aquatica, Ulmus americana, Liquidambar styraciflua, Quercus phellos, Carpinus caroliniana, and Quercus nigra.

Soils and climate - The soil series range from Bibb in the lowest areas to Riverview at the highest elevations. The Chastain series occurs at intermediate elevations. Average annual rainfall in this area is $117 \mathrm{~cm}$, and the average growing season is 232 days.

Designated zones - Zones 2, 3, 4, and 6 were delineated for study. Zone 5 was too narrow to provide reliable data. 


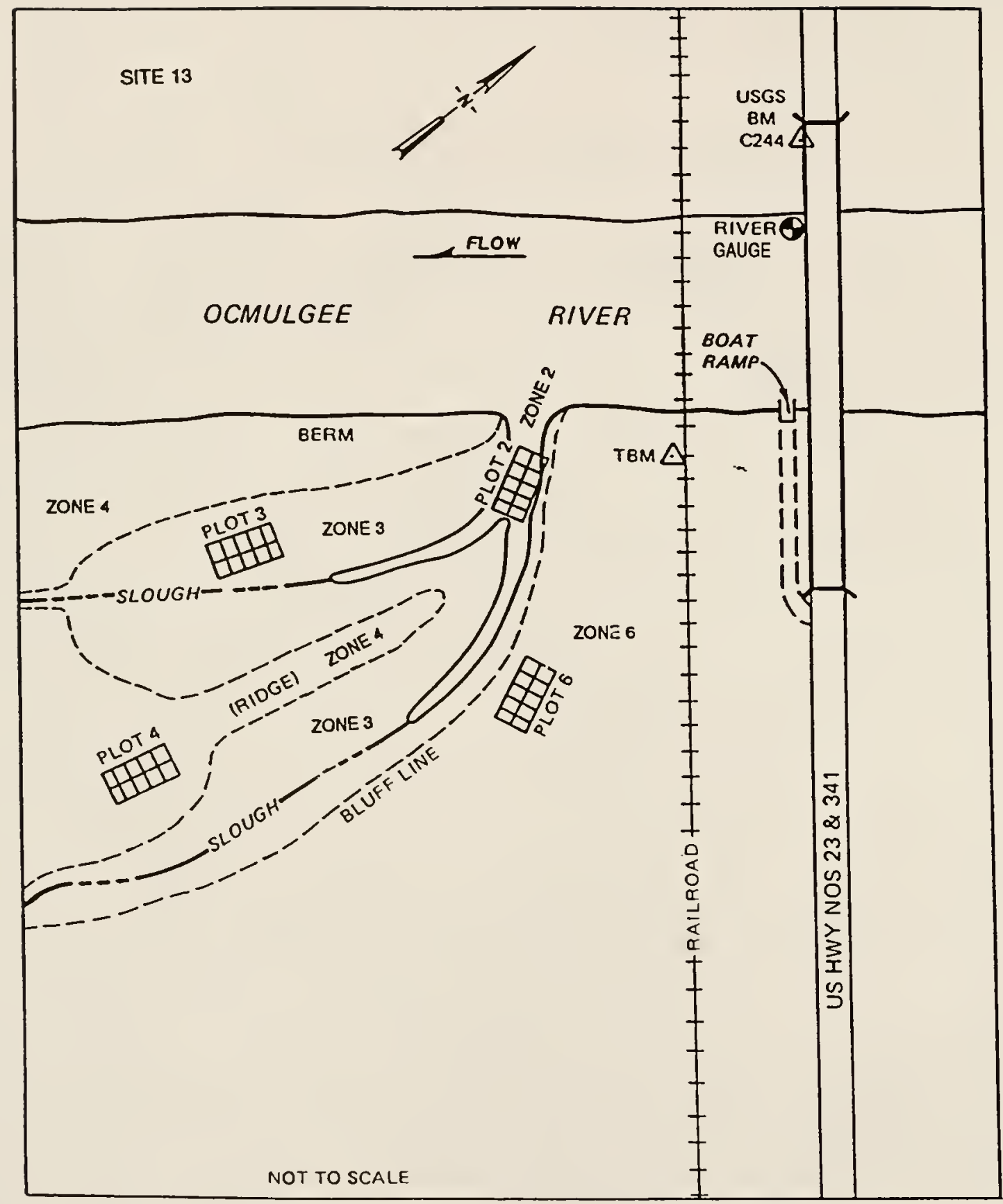

Figure A-10. Ocmulgee River (site 13) 
Altamaha River (Site 14)

Location (Altamaha River basin) - This site is located in the northeast quadrant at the intersection of U.S. Highway $l$ and the Altamaha River, $50 \mathrm{~km}$ north of Baxley in Toombs County, Georgia. Reference USGS map, Baxley NE, Georgia, N3152.5-W8215/7.5, 1970.

Hydrology data - Twelve years of hydrology data were analyzed for a gauge on the U.S. Highway 1 bridge adjacent to the site. No slope correction was necessary.

General vegetation - Plant communities range from Taxodium distichumNyssa aquatica at lowest elevations to a Juniperus virginiana-Quercus stellata-Carya tomentosa-Pinus taeda community at highest elevations. Intermediate communities are dominated by Fraxinus pennsylvanica, Quercus michauxii, Quercus phellos, and Carpinus caroliniana.

Soils and climate - Soils range from the Osier series in lowest elevations to the Riverview series at highest elevations. The Chewacla series occurs at intermediate elevations. Average annual rainfall is $117 \mathrm{~cm}$, and the average growing season is 232 days.

Designated zones - Zones delineated for this study site were 2, 5, and 6 . Zones 3 and 4 had ridge and swale topography which prevented separating them reliably. 


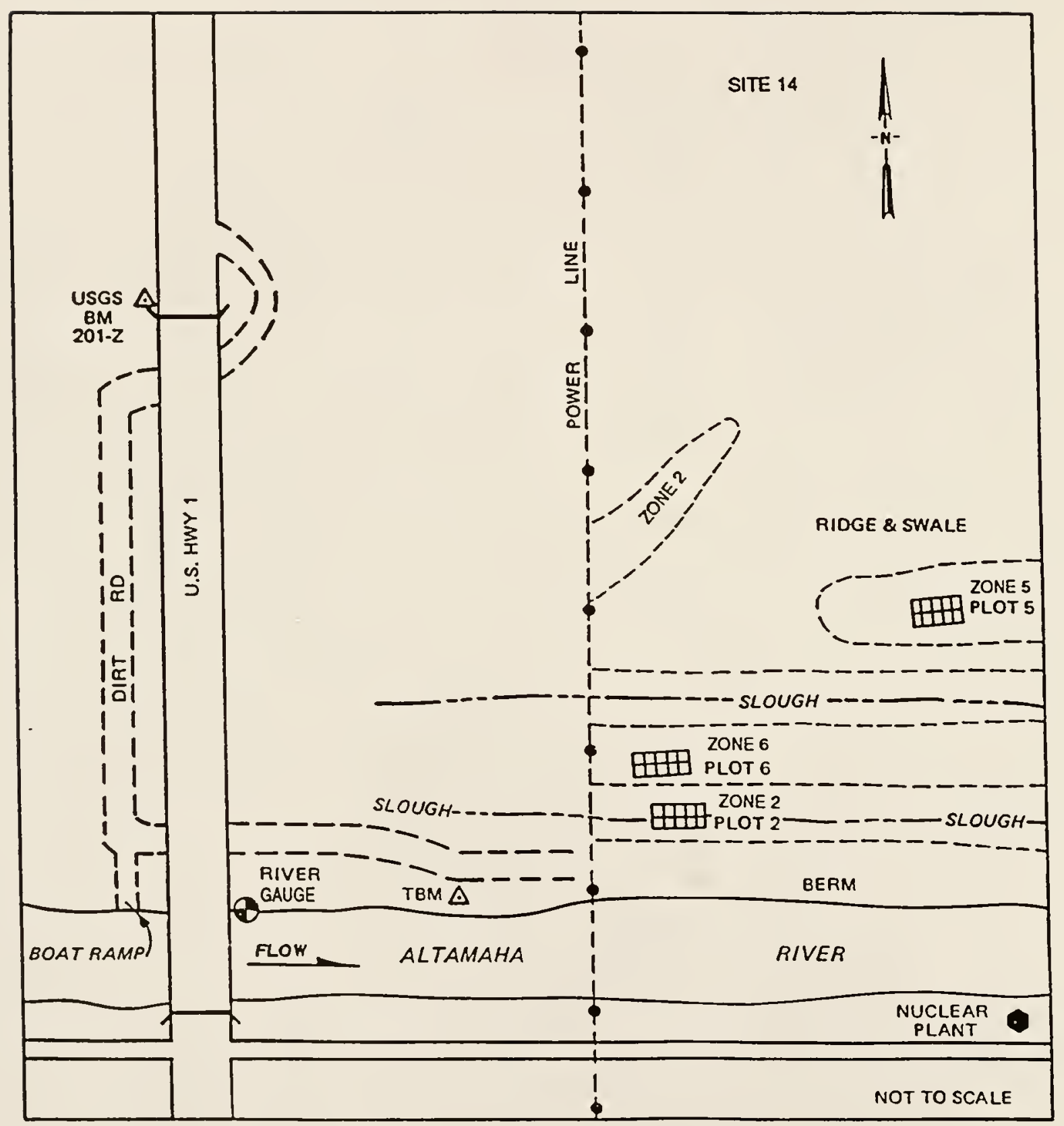

Figure A-11. Altamaha River (site 14) 
Edisto River (Site 15)

Location (Edisto River Basin) - This site is in Givhans Ferry State Park, north and west of South Carolina Highway 61 bridge, $4.8 \mathrm{~km}$ west of Givhans in Colleton County, South Carolina. Reference USGS map, Maple Cane Swamp, South Carolina, N3300-W8022.5/7.5, 1979.

Hydrology data - Twenty years of hydrology data were analyzed for a gauge on the South Carolina Highway 61 bridge adjacent to the site. No slope correction was necessary at this site.

General vegetation - Plant communities range from Taxodium distichumNyssa aquatica-Fraxinus caroliniana at lowest elevations to a Pinus taeda-Quercus virginiana-Quercus nigra dominated community at highest elevation. Species in communities at intermediate elevations include Quercus lyrata, Quercus laurifolia, Planera aquatica, Liquidambar styraciflua, Quercus nigra, and Carpinus caroliniana.

Soils and climate - Soil series range from Osier at lowest elevations to Chipley at highest elevations. The Torhunta soil series occurs at intermediate elevations. Average annual rainfall is $132 \mathrm{~cm}$, and the average growing season is 213 days.

Delineated zones - Zones 2, 3, 4, and 6 were delineated, but Zone 5 was too narrow due to its topographic position. 


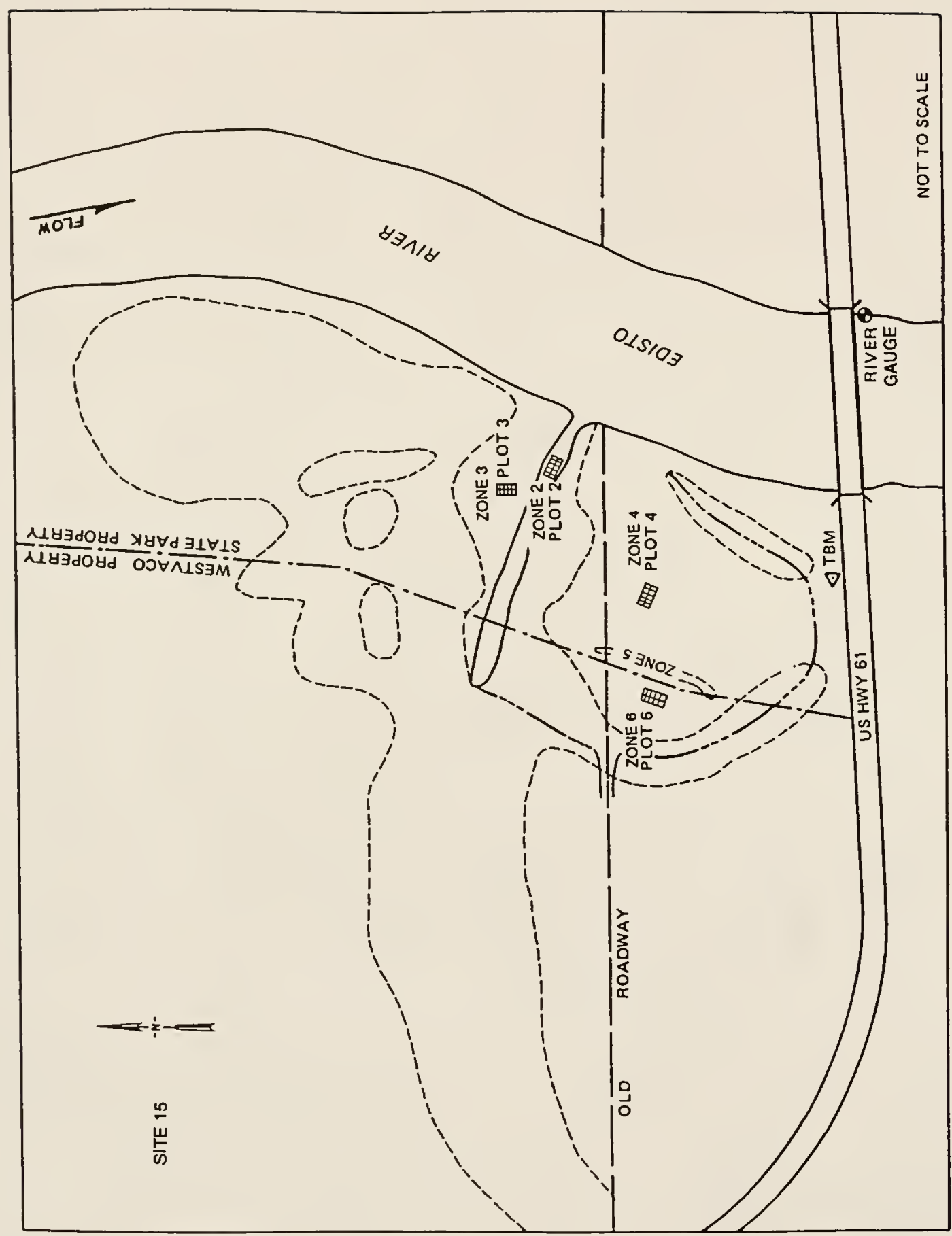

年 
Lynches River (Site 16)

Location (Lynches River Basin) - This site is located in Lynches River State Park, $1.6 \mathrm{~km}$ south of Effingham in Florence County, South Carolina. Reference USGS map, Florence West, South Carolina, N3400W7945/15, 1940 .

Hydrology data - Twenty years of hydrology data were analyzed for a gauge on the bridge on U.S. Highway $52,1.6 \mathrm{~km}$ south of Effingham. A slope correction from gauge to site was determined by a water surface profile.

General vegetation - Plant communities range from Taxodium distichumNyssa aquatica at the lowest elevations to Quercus falcata-Quercus stellata-Carya tomentosa at higher elevations. Species occurring in communities at intermediate elevations include Quercus Iyrata, Quercus laurifolia, Liquidambar styraciflua, and Quercus phellos.

Soils and climate - Soil series range from Chastain at lowest elevations to Chipley at highest elevations, with the Wehadkee series at intermediate elevations. Average annual rainfall is $107 \mathrm{~cm}$, and the average growing season is 237 days.

Delineated zones - Zones 2, 3, and 6 were delineated for study. Zones 4 and 5 were too narrow to delineate due to their topographic positions. 


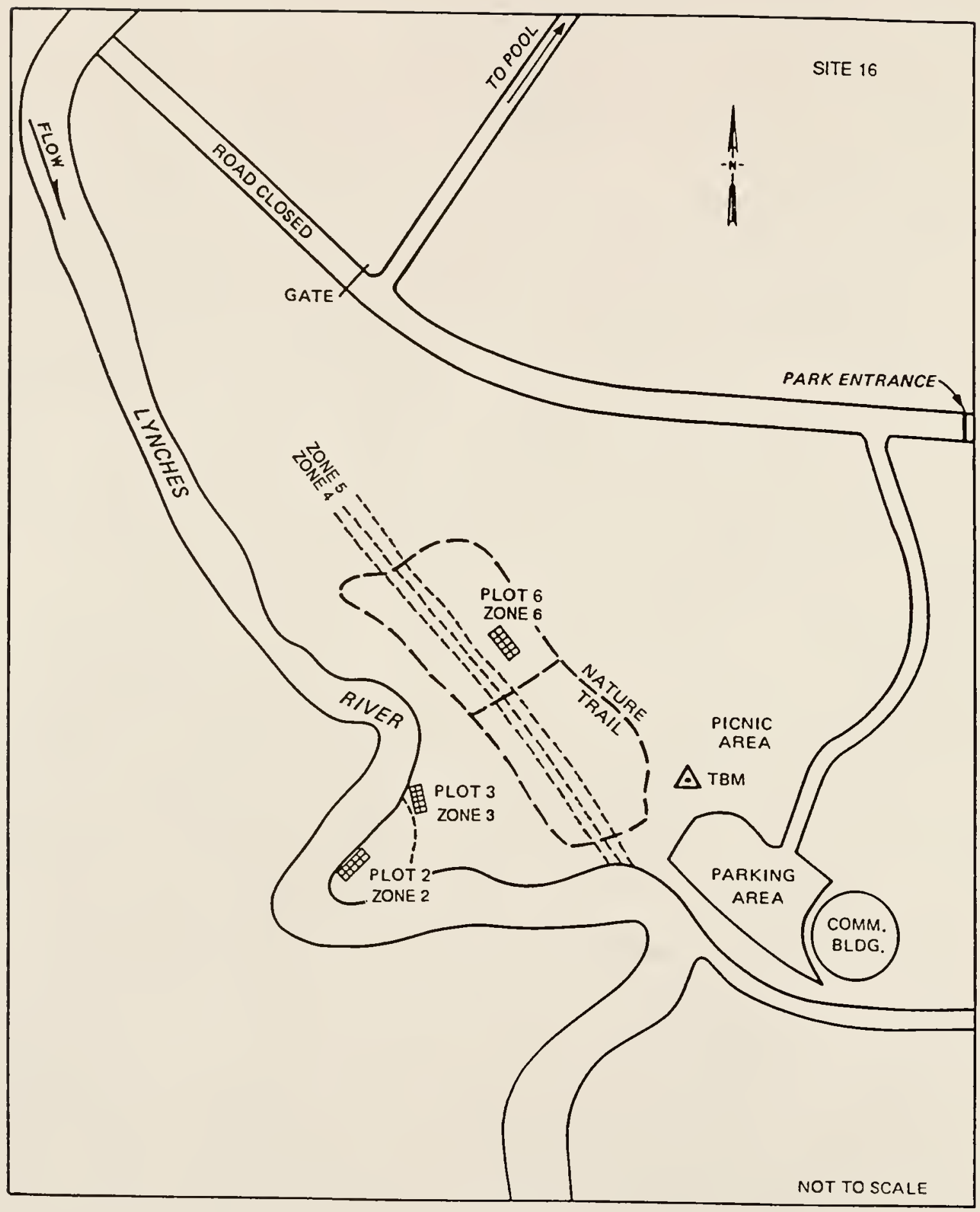

Figure A-13. Lynches River (site 16) 
Waccamaw River (Site 17)

Location (Waccamaw River Basin) - This site is located $3.2 \mathrm{~km}$ southeast of Longs in Horry County, South Carolina. Reference USGS map, Longs, South Carolina-North Carolina, N3352.5-W7837.5/7.5, 1947.

Hydrology data - Twenty years of hydrology data were analyzed for a gauge on the bridge on State Highway $9,3.4 \mathrm{~km}$ southeast of Longs, South Carolina. No slope correction was necessary.

General vegetation - Plant communities range from a Fraxinus caroliniana dominated swamp at the lowest elevation to a Pinus taeda-Quercus nigraLiquidambar styraciflua-dominated community at the highest elevation. Vegetation dominated by Quercus laurifolia, Magnolia virginiana, Acer rubrum, loblolly bay, Ilex opaca, Quercus phellos, and Quercus michauxii occurs at intermediate elevations.

Soils and climate - Soils range from the very poorly drained Rutledge series at the lowest elevations to the moderately well drained Chipley series at highest elevation. Soils at intermediate elevations include the Rembert and Leon series. Average annual rainfall is $107 \mathrm{~cm}$, and the average growing season is 248 days.

Delineated zones - Zones 2, 3, 4, and 6 were delineated for this site. Zone 5 was too narrow to delineate due to its topographic position. 


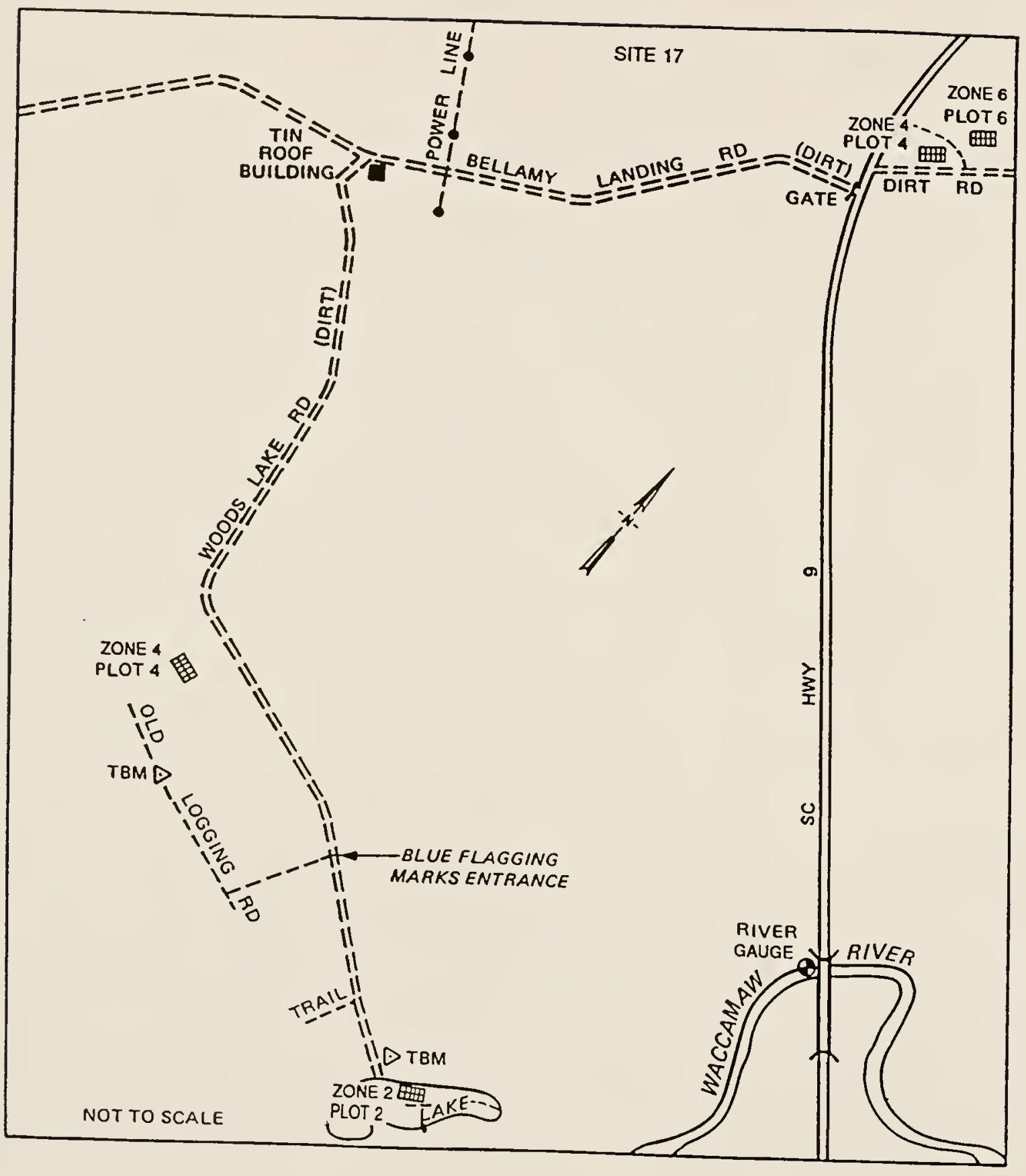

Figure A-14. Waccamaw River (site 17) 
APPENDIX B

GUIDE FOR COMPUTER PROGRAM FOR ANALYZING HYDROLOGIC DATA 


\section{Introduction}

\section{Program Development}

The FORTRAN computer program was developed to streamline hydrologic data manipulation for hydrologic zone boundary determinations.

\section{Overview of Program Capabilities}

The program defines the lower limits of four hydrologic zone boundaries, enabling determination of five zones. Recognizing the inherent variability of some input parameters, the program allows input of a range of parameters values, thus yielding a range of boundary values. The program reads either standard formatted U.S. Geological Survey (USGS) flow rate or Corps of Engineers stage data.

\section{Basis for Hydrologic Zone Delineation}

\section{Definitions}

Hydrologic zones. The program assumes the following definitions for hydrologic zone boundaries:
$\underline{\text { Zone }}$
Definition
Soil inundated or saturated on average greater than 75 percent of the growing season.
Soil inundated or saturated on average between 75 and 25 percent of the growing season.
Soil inundated or saturated on average between 25 and
5 Soil inundated or saturated on average between
12.5 percent of the growing season.
12.5 and 5 percent of the growing season.
6 Soil inundated or saturated on average less than 5 percent of the growing season.

Inundation. Inundation is defined as the physical overtopping of the soil by the adjacent stream water surface.

Saturation. A soil is saturated when it will no longer absorb water without losing an equal amount.

Growing season. The growing season is defined as the average frostfree period. It is the period between the last average occurrence of $32^{\circ} \mathrm{F}$ in the spring and the first average occurrence of $32^{\circ} \mathrm{F}$ in the fall. 
Separation of Data into Growing Seasons

Required inputs. The program used the starting and ending dates of the growing season and the daily flow rates or daily stage data at each site for a period of 10 to 20 years as input. Henceforth, the terms "flow rate" and "stage" are interchangeable, depending on the form of input data.

The program read flow rate data into a matrix $F L(I, J)$, where $I$ is an index designating year, and $J$ designated the Julian date. For example, FL(3,3) designated the flow rate of January 3 of the third year of data and FL $(3,33)$ designated February 2 of the third year. Two matrices, K5GS(I) and KEGS(I), were created that contained Julian dates of the beginning and end of the growing season in each year $I$. These dates varied due to leap years.

The program then created two more matrices: FLGS $(I, J)$ and NDGS(I). FLGS $(I, J)$ contained flow rates in year $I$, on date $J$ from the beginning of the growing season. For example, FLGS $(2,3)$ designated the flow rate on the third day of the growing season in the second year of data. NDGS(I) is the number of days in the growing season of the $I^{\text {th }}$ year. Again, this varied due to leap years.

Computation of Days Inundated

Computation of days inundated at a given flow rate proceeded as follows :

1. Growing season flow rates for the entire entered record were ranked from highest to lowest. This was accomplished by transferring all data in the FLGS(I,J) matrix into a single subscripted matrix $\operatorname{RANK}(K)$, and then ranked the data in RANK using a bubble sorting routine. RANK(1) represented the greatest flow rate for the entire record. RANK(NQ) was the lowest flow rate, where NQ was the total number of growing season flow rates in the entire record.

2. The number of days a given flow rate was exceeded (i.e., effecting inundation above that flow rate) within the growing season record was equal to the flow rate's ranking. A flow rate in RANK(10) was equalled or exceeded 10 times within the historic record and corresponded to 10 days of inundation.

\section{Computation of Days Saturated}

General. The model for the program was a simplified water balance. The soil root zone for wetland plant species was considered to be a water bucket, where:

1. Depth of the bucket was the critical depth of the saturated zone $(\mathrm{e} . \mathrm{g} ., 25 \mathrm{~cm})$.

2. When water overtopped the bucket (i.e., during inundation), the bucket filled at a rate PKW (inches/hour). 
3. When inundation ceased, the bucket drained at a rate $\mathrm{PKD}$ (inches/hour).

4. DEVAPR inches of water were lost daily out the top of the bucket by evapotranspiration.

5. When the bucket was partially full (i.e., not empty or overtopped by inundation), a day of saturation was counted.

Inputs. The following inputs were required for computing days of saturation:

1. $P K D=$ rate of percolation of water through the soil column. This was estimated from soil conservation service county soil surveys.

2. $\quad$ PKW $=$ rate at which inundation restores the soil zone to full saturation (inches/hour). (Note: $P K W$ is different from $P K D$ when the underlying soil layer was less porous than the upper soil layer. The soil would wet at the permeability rate of the upper layer, but would drain at the permeability rate of the underlying soil layer).

3. $\operatorname{CDSZ}=$ critical depth of the saturated zone, which was the depth of wetland plant root zone (10 in.).

4. DEVAPR = average daily evapotranspiration rate for the site (inches/day).

Discussion. This model has no pretense of absolute accuracy; it does not include rainfall, contributions of water from upslope drainage, residual soil moisture held by soil after gravity drainage, and possibly other sources of water.

Program algorithm, for a "fixed" flow rate. The following describes the program algorithm for a "fixed" flow rate (used at each zone boundary) for computation of days saturated:

1. For each year, the program started at CDSZ $/ 24 *$ PKW days before the growing season, with an empty "bucket," and used the general scheme described above to find the depth of water in the root zone at the start of the growing season. A flow rate in the record greater than the "fixed" flow rate filled the "bucket," while a lesser flow rate drained the "bucket."

2. For each year, the program then checked each growing season flow rate versus the "fixed" flow rate using this starting water depth, and either filled or drained the bucket as appropriate. Each day when the bucket was partially full counts as a day saturated.

3. Days saturated for each year were added into a single total for that "fixed" flow rate. 
4. A flowchart showing program logic for computation of days saturated is provided in Figure $\mathrm{C}-1$.

Computation of Frequency of Inundation

General. Frequency of inundation was not used in defining hydrologic zone boundaries. However, it was used for discussion purposes.

Frequency of inundation for a given flow rate was determined by:

1. Counting the number of growing seasons in the historic record during which the flow rate for a particular hydrologic zone was exceeded at least once for a minimum of 7 days.

2. Dividing the total number of years in the record into "a," and multiplying by 100 .

For example: A flow rate of 20,000 cubic feet per second is exceeded in only two growing seasons of a 20 -year record. This flow rate has a frequency of inundation of $2 / 20 \times 100=10$ percent.

Computation of Parameters in Tabular Output

Tabular output appeared as follows:

(6)

DAYS

$$
\text { DAYS }
$$

FREQ

BOUNDARY

INUN -

INUN -

SATURATED

FLOWRATE

DATED

DURATION

INUNDATED

DATED

DAYS

PLUS DAYS

DURATION

38852 .

33.

4.3

100.0

SATURATED

INUNDATED

SATURATED

AND

INUNDATED

Al1 of the above have already been explained except columns (3), (6) and (7) .

1. $\underline{\text { Column } 3}$ - Duration inundated $=\frac{\text { days inundated }}{\text { total growing season }} \times 100$.

2. Column 6 - Days saturated plus days inundated $=$ Columns $2+5$.

3. Column 7 -

$$
\frac{\begin{array}{c}
\text { Duration saturated } \\
\text { and inundated }
\end{array}}{\text { total growing season days }} \times 100 \text {. }
$$




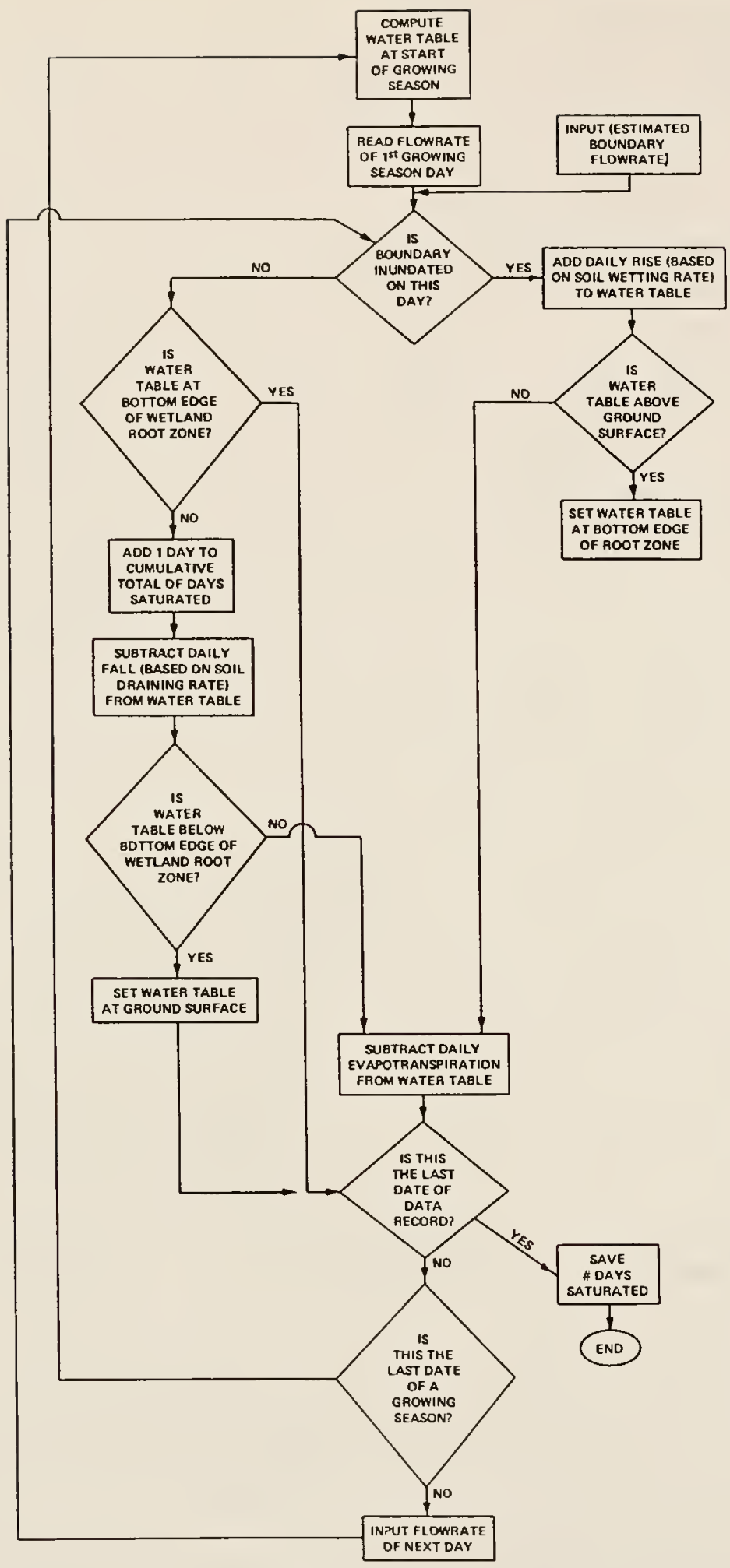

Figure B-1. Program logic for computation of days saturated 
EXAMPLE SUMMARY TABLE OF

BOUNDARY FLOWRATES

$\begin{array}{lccc}\text { ZONE V } & \text { ZONE IV } & \text { ZONE III } & \text { ZONE II } \\ 155 . & 144 . & 128 . & 63 .\end{array}$

NSMGS $=3$ NSDGS $=3$ NEMGS $=11$ NEDGS $=11 \quad \mathrm{PKW}=.90000 \quad \mathrm{PKD}=.90000 \quad \mathrm{CDSZ}=10.0$ $\operatorname{DEVAP}=.200$

\begin{tabular}{|c|c|c|c|c|c|c|}
\hline & DAYS & & FREQ & & $\begin{array}{l}\text { DAYS } \\
\text { SATURATED }\end{array}$ & $\begin{array}{l}\text { DURATION } \\
\text { SATURATED }\end{array}$ \\
\hline BOUNDARY & INUN - & DURATION & INUN - & DAYS & PLUS DAYS & AND \\
\hline FLOWRATE & DATED & INUNDATED & $\underline{\text { DATED }}$ & SATURATED & INUNDATED & INUNDATED \\
\hline 155. & 22 . & 4.3 & 100.0 & 2 . & 24. & 4.7 \\
\hline 144. & 48. & 9.4 & 100.0 & 7. & 55. & 10.8 \\
\hline 128. & 116. & 22.8 & 100.0 & 11. & 127. & 25.0 \\
\hline 63. & 375 . & 73.8 & 100.0 & 11. & 386. & 76.0 \\
\hline
\end{tabular}


APPENDIX C

HYDROGRAPH FOR STEELE BAYOU (SITE 3) 


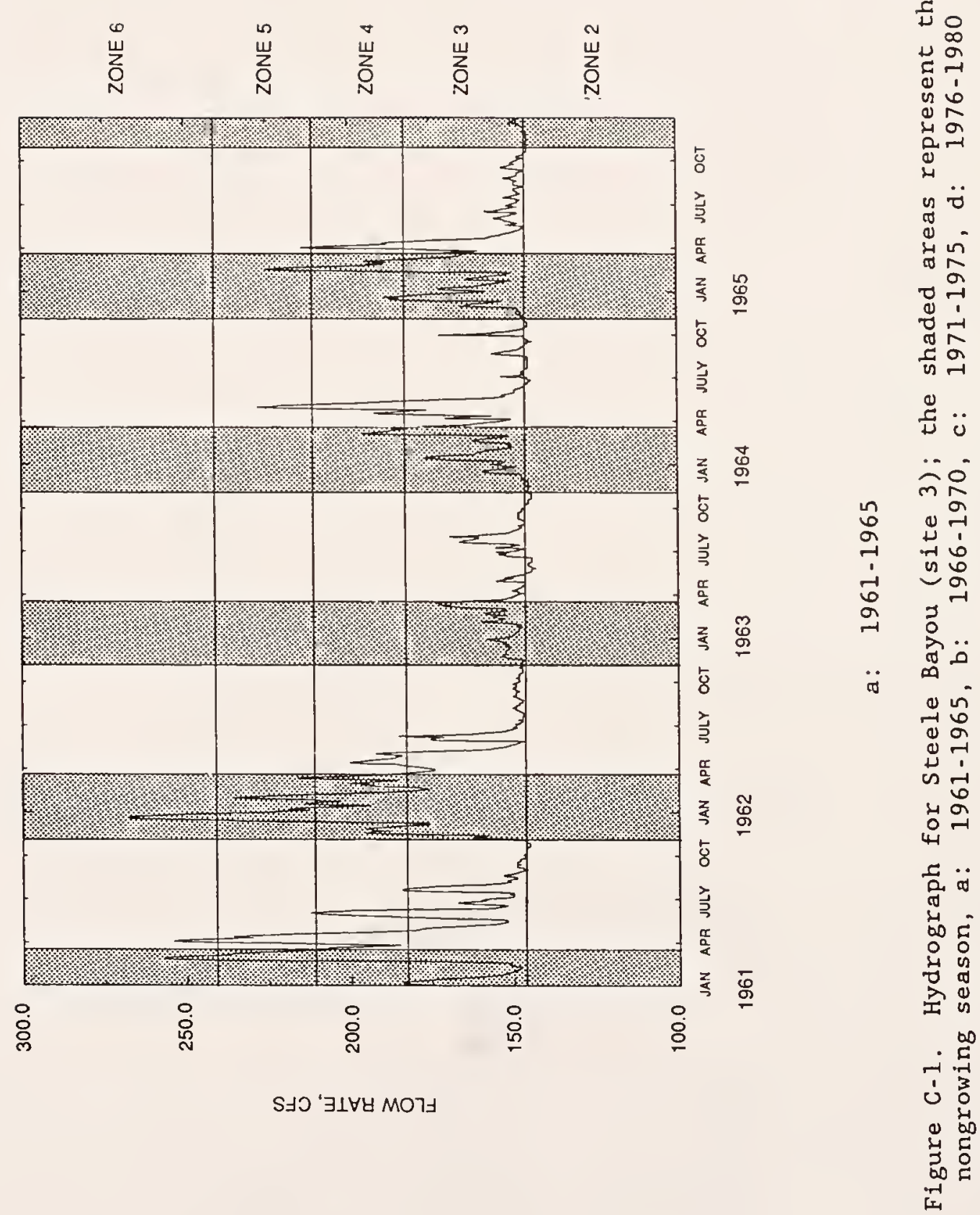




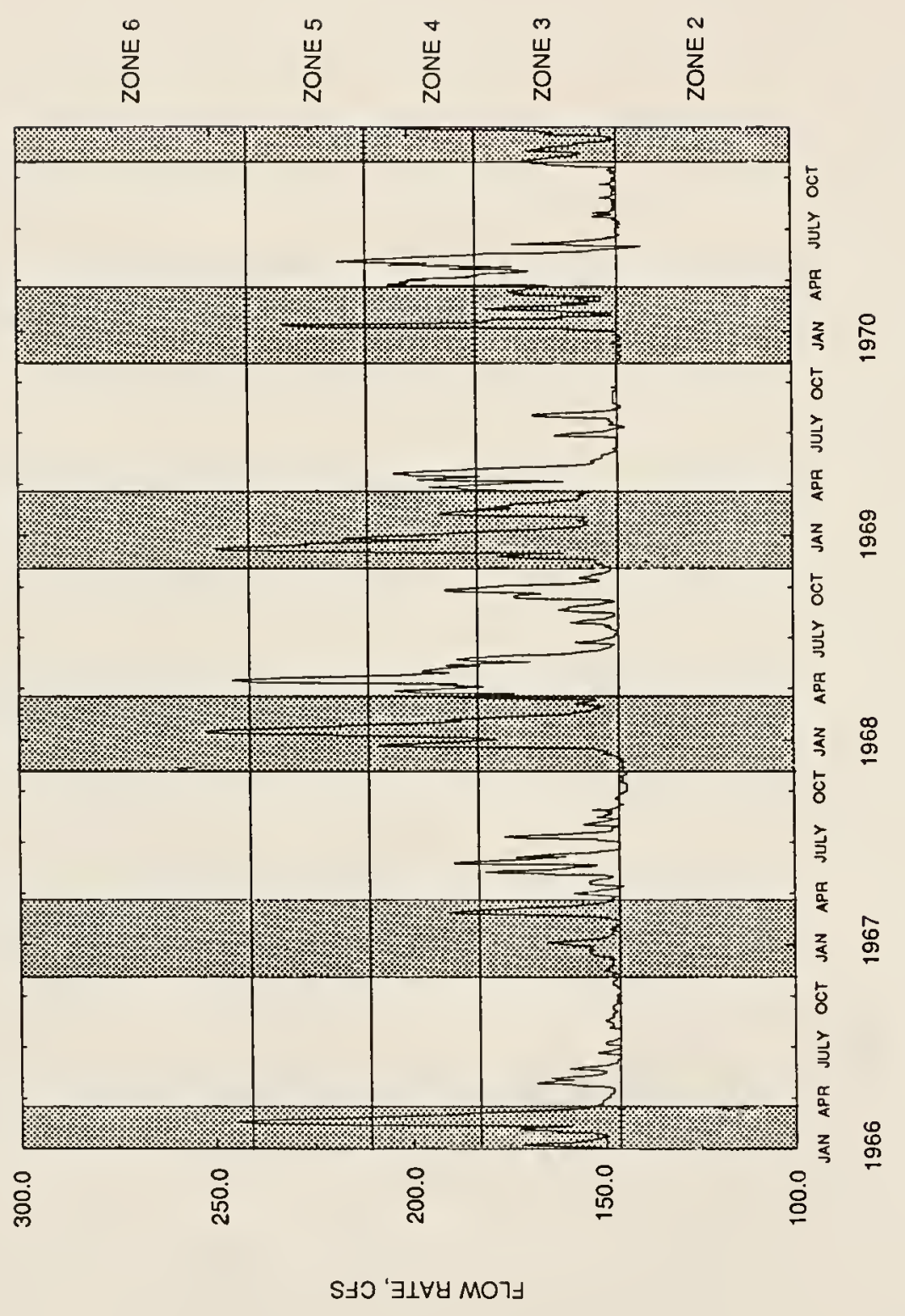

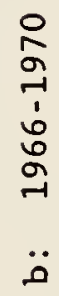




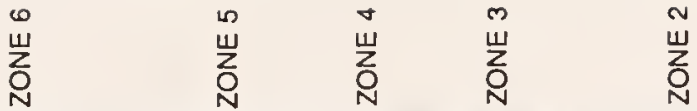

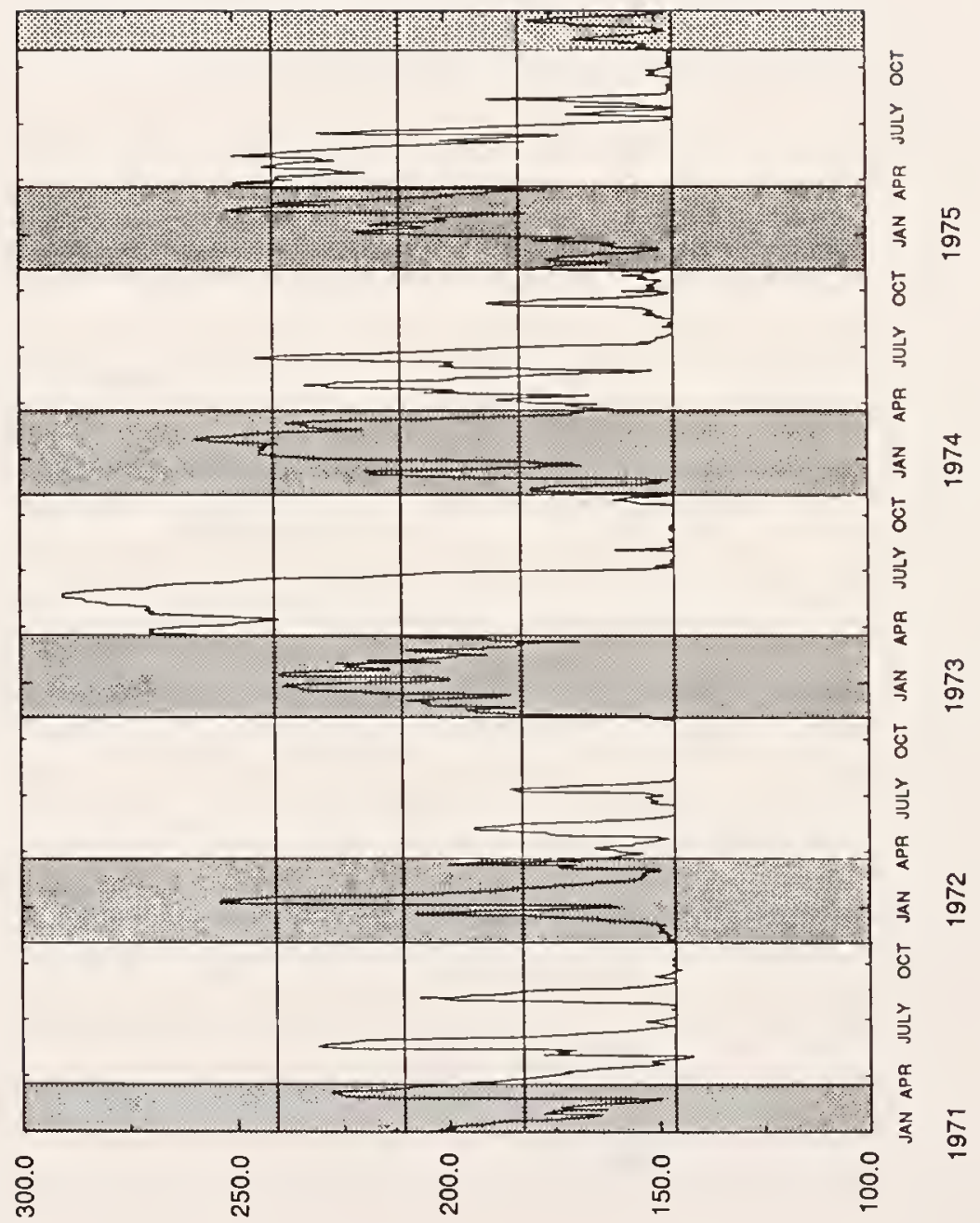




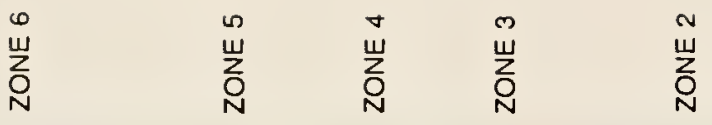

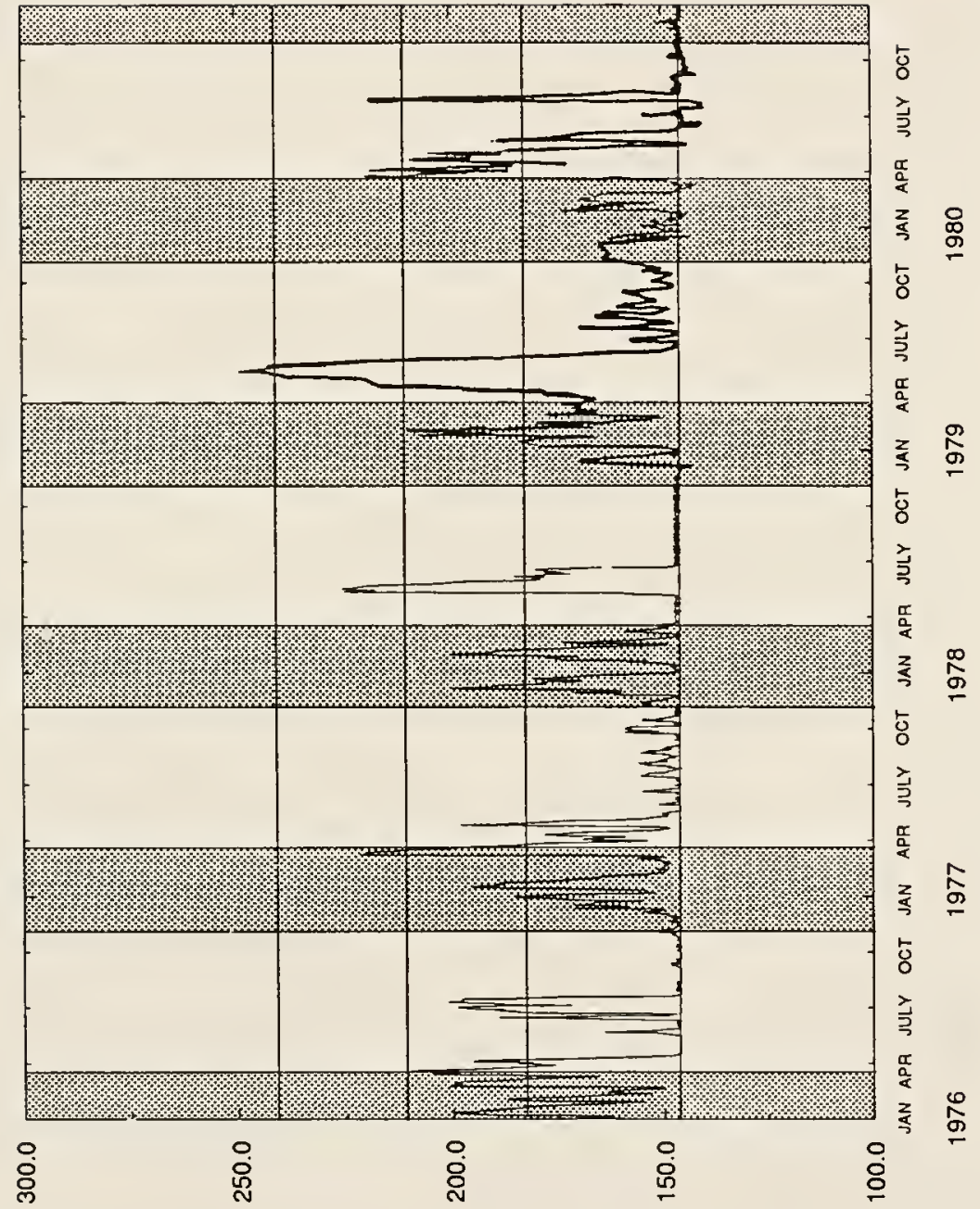


APPENDIX D

IMPORTANCE VALUES FOR SPECIES BY ZONE AND VEGETATION LAYER 
Table D-1

Importance Values for Species Occurring at Site 1.

Arranged by Zone and Vegetation Layer

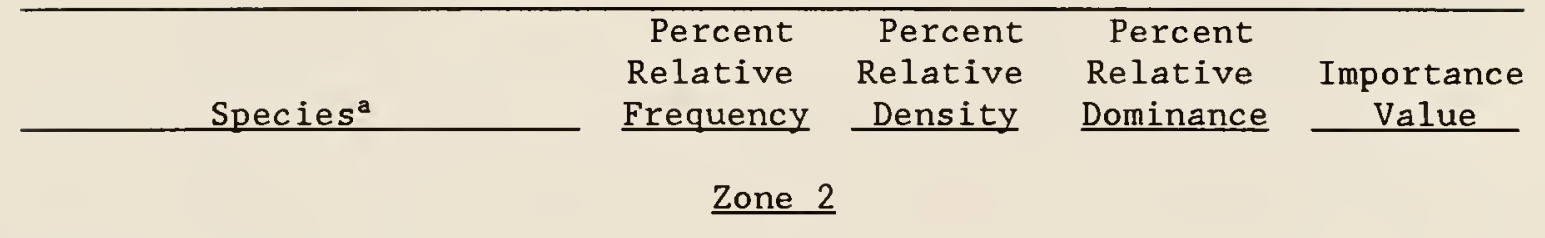

\section{Trees}

Taxodium distichum

Nyssa aquatica

Planera aquatica

Fraxinus caroliniana

Cephalanthus occidentalis

\begin{tabular}{|c|c|}
\hline 31.8 & 44.0 \\
\hline 31.8 & 16.7 \\
\hline 18.2 & 31.8 \\
\hline 13.6 & 6.0 \\
\hline 4.6 & 1.5 \\
\hline 100.0 & 100.0 \\
\hline
\end{tabular}

$\begin{array}{r}42.2 \\ 49.2 \\ 7.3 \\ 0.9 \\ 0.4 \\ \hline 100.0\end{array}$

118.0

97.8

57.3

6.0

20.5

$\frac{6.4}{300.0}$

Saplings and Shrubs

Planera aquatica

Cephalanthus occidentalis

45.4

47.0

49.7

142.1

27.3

29.4

18.2

17.7

Taxodium distichum

$\frac{9.1}{100.0}$

$\frac{5.9}{100.0}$

24.1

80.8

19.7

55.6

$\frac{6.5}{100.0}$

$\frac{21.5}{300.0}$

Woody Vines

None present

Herbs and Woody Seedlings

Styrax americana

Planera aquatica

Cephalanthus occidentalis

\begin{tabular}{rrrr}
33.3 & $\cdots$ & 33.4 & 66.7 \\
33.4 & $\cdots$ & 33.3 & 66.7 \\
33.3 & -- & $\frac{33.3}{100.0}$ & 206.6 \\
\hline 100.0 & & 200.0
\end{tabular}

Zone 3

\section{Trees}

Quercus lyrata

Quercus laurifolia

Carya aquatica

Diospyros virginiana

Fraxinus caroliniana

Planera aquatica

Taxodium distichum

Acer drummondi $i$

$\begin{array}{rrrr}17.8 & 13.6 & 25.6 & 57.0 \\ 8.9 & 6.8 & 25.1 & 40.8 \\ 11.7 & 9.1 & 18.2 & 39.0 \\ 11.7 & 18.1 & 5.8 & 35.6 \\ 14.8 & 15.9 & 3.9 & 34.6 \\ 11.7 & 11.4 & 5.1 & 28.2 \\ 11.7 & 11.4 & 2.9 & 26.0 \\ 5.9 & 9.1 & 10.0 & 25.0\end{array}$

a No FTI numbers were calculated for plants not identified by species. 
Table D-1--continued

\begin{tabular}{|c|c|c|c|c|}
\hline Species & 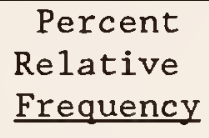 & $\begin{array}{r}\text { Percent } \\
\text { Relative } \\
\text { Density } \\
\end{array}$ & $\begin{array}{c}\text { Percent } \\
\text { Relative } \\
\text { Dominance }\end{array}$ & $\begin{array}{c}\text { Importance } \\
\text { Value } \\
\end{array}$ \\
\hline Liquidambar styraciflua & 2.9 & 2.3 & 3.2 & 8.4 \\
\hline \multirow[t]{2}{*}{ Gleditsia aquatica } & 2.9 & 2.3 & 0.2 & 5.4 \\
\hline & 100.0 & 100.0 & 100.0 & 300.0 \\
\hline \multicolumn{5}{|l|}{ Saplings and Shrubs } \\
\hline Acer drummondii & 9.1 & 29.1 & 21.1 & 59.3 \\
\hline Ilex decidua & 12.1 & 16.9 & 21.1 & 50.1 \\
\hline Planera aquatica & 15.2 & 12.3 & 14.7 & 42.2 \\
\hline Taxodium distichum & 18.3 & 10.8 & 10.6 & 39.7 \\
\hline Fraxinus caroliniana & 12.1 & 12.3 & 13.2 & 37.6 \\
\hline Cephalanthus occidentalis & 12.1 & 6.2 & 8.1 & 26.4 \\
\hline Styrax americana & 12.1 & 7.7 & 6.0 & 25.8 \\
\hline Crataegus viridis & 6.0 & 3.1 & 3.1 & 12.2 \\
\hline \multirow[t]{2}{*}{ Carpinus caroliniana } & 3.0 & 1.6 & 2.1 & 6.7 \\
\hline & $\overline{100.0}$ & 100.0 & $\overline{100.0}$ & $\overline{300.0}$ \\
\hline \multicolumn{5}{|l|}{ Woody Vines } \\
\hline Brunnichia cirrhosa & 106.6 & 33.3 & 36.9 & 36.4 \\
\hline Vitis palmata & 33.3 & 26.3 & 36.4 & 96.5 \\
\hline Ampelopsis arborea & 25.0 & 21.0 & 17.0 & 63.0 \\
\hline \multirow[t]{2}{*}{ Smilax rotundifolia } & 8.4 & 15.8 & 9.7 & 33.9 \\
\hline & $\overline{100.0}$ & $\overline{100.0}$ & $\overline{100.0}$ & $\overline{300.0}$ \\
\hline \multicolumn{5}{|l|}{ Herbs and Woody Seedlings } \\
\hline Justicia ovata & 26.7 & -- & 42.4 & 69.1 \\
\hline Quercus laurifolia & 18.4 & - & 27.5 & 45.9 \\
\hline Planera aquatica & 8.3 & - & 4.6 & 12.9 \\
\hline Fraxinus caroliniana & 10.3 & - & 2.4 & 12.7 \\
\hline Brunnichia cirrhosa & 4.1 & $\cdots$ & 8.3 & 12.4 \\
\hline Diodia virginiana & 6.1 & $\cdots$ & 4.1 & 10.2 \\
\hline Carya aquatica & 6.1 & - & 4.1 & 10.2 \\
\hline Saururus cernuus & 2.0 & -- & 3.0 & 5.0 \\
\hline Vitis palmata & 2.0 & - & 0.4 & 2.4 \\
\hline Ulmus americana & 2.0 & - & 0.4 & 2.4 \\
\hline Smilax walteri & 2.0 & -- & 0.4 & 2.4 \\
\hline Smilax sp. & 2.0 & - & 0.4 & 2.4 \\
\hline Crataegus viridis & 2.0 & -- & 0.4 & 2.4 \\
\hline Carex sp. & 2.0 & - & 0.4 & 2.4 \\
\hline Ampelopsis arborea & 2.0 & - & 0.4 & 2.4 \\
\hline Acalypha gracilens & 2.0 & - & 0.4 & 2.4 \\
\hline \multirow[t]{3}{*}{ Acer drummondii } & 2.0 & - & 0.4 & 2.4 \\
\hline & 100.0 & & 100.0 & 200.0 \\
\hline & $\underline{\text { Zone }}$ & & & \\
\hline \multicolumn{5}{|l|}{ Trees } \\
\hline Carpinus caroliniana & 37.1 & 50.1 & 21.1 & 108.3 \\
\hline
\end{tabular}


Table D-1--continued

\begin{tabular}{|c|c|c|c|c|}
\hline Species & 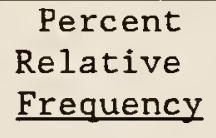 & $\begin{array}{r}\text { Percent } \\
\text { Relative } \\
\text { Density } \\
\end{array}$ & $\begin{array}{r}\text { Percent } \\
\text { Relative } \\
\text { Dominance }\end{array}$ & $\begin{array}{c}\text { Importance } \\
\text { Value }\end{array}$ \\
\hline Liquidambar styraciflua & 14.8 & 19.2 & 35.8 & 69.8 \\
\hline Ulmus americana & 11.1 & 5.8 & 5.8 & 22.7 \\
\hline Quercus michauxii & 3.7 & 1.9 & 12.1 & 17.7 \\
\hline Quercus laurifolia & 3.7 & 1.9 & 10.3 & 15.9 \\
\hline Diospyros virginiana & 7.4 & 5.8 & 1.8 & 15.0 \\
\hline Nyssa sylvatica & 7.4 & 5.8 & 1.3 & 14.5 \\
\hline Quercus lyrata & 3.7 & 1.9 & 8.6 & 14.2 \\
\hline Crataegus viridis & 7.4 & 3.8 & 1.0 & 12.2 \\
\hline \multirow[t]{2}{*}{ Ilex opaca } & 3.7 & 3.8 & 2.2 & 9.7 \\
\hline & 100.0 & 100.0 & 100.0 & 300.0 \\
\hline \multicolumn{5}{|l|}{ Saplings and Shrubs } \\
\hline Ilex decidua & 38.8 & 63.1 & 64.8 & 166.7 \\
\hline Carpinus caroliniana & 37.7 & 21.7 & 22.6 & 72.0 \\
\hline Nyssa sylvatica & 11.1 & 4.3 & 5.1 & 20.5 \\
\hline Sebastiania fruticosa & 5.6 & 4.3 & 1.4 & 11.3 \\
\hline Quercus 1yrata & 5.6 & 2.2 & 2.5 & 10.3 \\
\hline Cartaegus viridis & 5.6 & 2.2 & 2.5 & 10.3 \\
\hline \multirow[t]{2}{*}{ Ilex Opaca } & 5.6 & 2.2 & 1.1 & 8.9 \\
\hline & 100.0 & 100.0 & 100.0 & 300.0 \\
\hline \multicolumn{5}{|l|}{ Woody Vines } \\
\hline Vitis palmata & 50.0 & 37.5 & 47.5 & 135.0 \\
\hline Toxicodendron radicans & 14.3 & 43.7 & 31.7 & 89.7 \\
\hline Bignonia capreolata & 14.3 & 9.4 & 8.9 & 32.6 \\
\hline Berchemia scandens & 14.3 & 6.3 & 7.9 & 28.5 \\
\hline \multirow{2}{*}{ Vitis rotundifolia } & 7.1 & 3.1 & 4.0 & 14.2 \\
\hline & $\overline{100.0}$ & $\overline{100.0}$ & $\overline{100.0}$ & $\overline{300.0}$ \\
\hline \multicolumn{5}{|l|}{ Herbs and Woody Seedlings } \\
\hline Justicia ovata & 10.7 & -- & 18.0 & 28.7 \\
\hline Bignonia capreolata & 10.7 & - & 16.0 & 26.7 \\
\hline Quercus laurifolia & 5.8 & - & 9.5 & 15.3 \\
\hline Mitche11a repens & 5.0 & - & 9.6 & 14.6 \\
\hline Carpinus caroliniana & 7.9 & - & 9.6 & 12.6 \\
\hline Toxicodendron radicans & 5.0 & -- & 6.6 & 11.6 \\
\hline U1mus americana & 7.2 & - & 2.9 & 10.1 \\
\hline Crataegus viridis & 4.3 & - & 3.3 & 7.6 \\
\hline Viola sp. & 3.5 & - & 1.8 & 5.3 \\
\hline Liquidambar styraciflua & 3.5 & -- & 1.5 & 5.0 \\
\hline Aristolochia serpentaria & 3.5 & - & 1.5 & 5.0 \\
\hline Lysimachia radicans & 1.4 & -- & 3.6 & 5.0 \\
\hline Smilax walteri & 2.1 & - & 2.4 & 4.5 \\
\hline Vitis palmata & 2.8 & $\cdots$ & 1.2 & 4.0 \\
\hline Dichanthelium commutatum & 2.8 & - & 1.2 & 4.0 \\
\hline Ampelops is arborea & 1.4 & -- & 2.1 & 3.5 \\
\hline Viola missouriensis & 2.1 & - & 0.9 & 3.0 \\
\hline
\end{tabular}


Table D-1--continued

\begin{tabular}{|c|c|c|c|c|}
\hline Species & 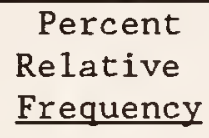 & $\begin{array}{r}\text { Percent } \\
\text { Relative } \\
\text { Density } \\
\end{array}$ & $\begin{array}{r}\text { Percent } \\
\text { Relative } \\
\text { Dominance } \\
\end{array}$ & $\begin{array}{c}\text { Importance } \\
\text { Value }\end{array}$ \\
\hline Quercus lyrata & 2.0 & $\cdots$ & 0.9 & 3.0 \\
\hline Aster lateriflorus & 2.1 & - & 0.9 & 3.0 \\
\hline Trachelospermum difforme & 0.7 & -- & 1.8 & 2.5 \\
\hline Justicia americana & 0.7 & - & 1.8 & 2.5 \\
\hline Campsis radicans & 0.7 & - & 1.8 & 2.5 \\
\hline Quercus michauxii & 1.4 & - & 0.6 & 2.0 \\
\hline Oxalis stricta & 1.4 & - & 0.6 & 2.0 \\
\hline Ilex opaca & 1.4 & - & 0.6 & 2.0 \\
\hline Eupatorum sp. & 1.4 & $\cdots$ & 0.6 & 2.0 \\
\hline Celtis laevigata & 1.4 & - & 0.6 & 2.0 \\
\hline Acer rubrum & 1.4 & - & 0.6 & 2.0 \\
\hline Vernonia gigantea & 0.7 & - & 0.3 & 1.0 \\
\hline Smilax bona-nox & 0.7 & - & 0.3 & 1.0 \\
\hline Sebastiania fruticosa & 0.7 & $\cdots$ & 0.3 & 1.0 \\
\hline Nyssa aquatica & 0.7 & - & 0.3 & 1.0 \\
\hline Mikania scandens & 0.7 & - & 0.3 & 1.0 \\
\hline Botrychium biternatum & 0.7 & $\cdots$ & 0.3 & 1.0 \\
\hline Acalypha gracilens & 0.7 & - & 0.3 & 1.0 \\
\hline \multirow[t]{2}{*}{ Acer drummondii } & 0.7 & - & 0.3 & 1.0 \\
\hline & $\overline{100.0}$ & & $\overline{100.0}$ & $\overline{200.0}$ \\
\hline
\end{tabular}

Zone 6

Trees

Liquidambar styraciflua

18.6

20.7

11.5

50.8

Carpinus caroliniana

18.6

20.7

3.4

42.7

Quercus nigra

Quercus falcata var.

9.3

6.9

18.6

34.8

9.3

6.9

14.3

30.5

Ostrya virginiana

11.5

13.9

3.0

28.4

4.7

3.4

19.3

27.4

Pinus taeda

3.4

16.3

24.4

7.0

8.6

5.2

20.8

Quercus alba

7.0

6.0

19.9

4.7

6.9

1.5

11.4

2.3

1.7

0.5

4.5

Morus rubra
Cornus florida

$\frac{2.3}{100.0}$

$\frac{0.4}{100.0}$

$\frac{4.4}{300.0}$

Saplings and Shrubs

Carpinus caroliniana

Ostrya virginiana

Ilex opaca

Liquidambar styraciflua

Nyssa sylvatica
33.2

27.8

11.1

11.1

5.6
30.1

23.3

16.7

13.3

10.0
36.6

27.8

12.2

8.9

8.5
99.9

78.9

40.0

33.3

24.1 
Table D-1--continued

\begin{tabular}{|c|c|c|c|c|}
\hline Species & $\begin{array}{c}\text { Percent } \\
\text { Relative } \\
\text { Frequency } \\
\end{array}$ & $\begin{array}{r}\text { Percent } \\
\text { Relative } \\
\text { Density } \\
\end{array}$ & $\begin{array}{c}\text { Percent } \\
\text { Relative } \\
\text { Dominance }\end{array}$ & $\begin{array}{c}\text { Importance } \\
\text { Value }\end{array}$ \\
\hline Cornus florida & 5.6 & 3.3 & 4.1 & 13.0 \\
\hline \multirow[t]{2}{*}{ Aralia spinosa } & 5.6 & 3.3 & 1.9 & 10.8 \\
\hline & 100.0 & 100.0 & 100.0 & 300.0 \\
\hline \multicolumn{5}{|l|}{ Woody Vines } \\
\hline$\overline{\text { Vitis rotundifolia }}$ & 66.7 & 75.0 & 75.0 & 216.7 \\
\hline \multirow[t]{2}{*}{ Bignonia capreolata } & 33.3 & 25.0 & 25.0 & 83.3 \\
\hline & 100.0 & 100.0 & 100.0 & 300.0 \\
\hline \multicolumn{5}{|l|}{ Herbs and Woody Seedlings } \\
\hline Quercus nigra & 17.8 & - & 27.3 & 45.1 \\
\hline Bignonia capreolata & 5.1 & -- & 12.3 & 17.4 \\
\hline Toxicodendron radicans & 9.0 & - & 4.4 & 13.4 \\
\hline Parthenocissus quinquefolia & 6.4 & -- & 3.1 & 9.5 \\
\hline Mitchella repens & 3.8 & -- & 5.1 & 8.9 \\
\hline Carpinus caroliniana & 5.1 & -- & 2.5 & 7.6 \\
\hline Pinus taeda & 2.6 & -- & 4.5 & 7.1 \\
\hline Smilax rotundifolia & 3.8 & - & 1.9 & 5.7 \\
\hline Quercus phellos & 3.8 & -- & 1.9 & 5.7 \\
\hline Dichanthelium commutatum & 3.8 & -- & 1.9 & 5.7 \\
\hline Ilex opaca & 3.8 & - & 1.9 & 5.7 \\
\hline Carex sp. & 3.8 & $\cdots$ & 1.9 & 5.7 \\
\hline Vitis rotundifolia & 1.3 & - & 3.9 & 5.2 \\
\hline Rubus sp. & 1.3 & -- & 3.9 & 5.2 \\
\hline Ilex vomitoria & 1.3 & -- & 3.9 & 5.2 \\
\hline Ascyrum hypericoides & 1.3 & -- & 3.9 & 5.2 \\
\hline Carex sp. & 1.3 & -- & 3.9 & 5.2 \\
\hline Viburnum dentatum & 2.6 & -- & 1.3 & 3.9 \\
\hline Ostrya virginiana & 2.6 & -- & 1.3 & 3.9 \\
\hline Oplismenus hirtellus & 2.6 & -- & 1.3 & 3.9 \\
\hline Berchemia scandens & 2.6 & -- & 1.3 & 3.9 \\
\hline Vaccinium elliottii & 1.3 & - & 0.6 & 1.9 \\
\hline Ampelamus albidus & 1.3 & -- & 0.6 & 1.9 \\
\hline $\begin{array}{l}\text { Quercus falcata var. } \\
\text { pagodifolia }\end{array}$ & 1.3 & - & 0.6 & 1.9 \\
\hline Quercus alba & 1.3 & -- & 0.6 & 1.9 \\
\hline Prunus serotina & 1.3 & -- & 0.6 & 1.9 \\
\hline Nyssa sylvatica & 1.3 & -- & 0.6 & 1.9 \\
\hline Ilex coriacea & 1.3 & -- & 0.6 & 1.9 \\
\hline Crataegus marshallii & 1.3 & -- & 0.6 & 1.9 \\
\hline Chasmanthium sessiliflorum & 1.3 & $\cdots$ & 0.6 & 1.9 \\
\hline Chasmanthium Iaxum & 1.3 & $\cdots$ & 0.6 & 1.9 \\
\hline \multirow[t]{2}{*}{ Arundinaria gigantea } & 1.3 & -- & 0.6 & 1.9 \\
\hline & 100.0 & & 100.0 & 200.0 \\
\hline
\end{tabular}


Table D-2

Importance Values for Species Occurring at Site 2.

Arranged by Zone and Vegetation Layer

Species

Percent

Relative

Frequency

Percent

Relative

Density
Percent

Relative

Dominance
Importance

Value

\section{Zone 2}

\section{Trees}

Nyssa aquatica

Taxodium distichum

Planera aquatica

Fraxinus caroliniana

Cephalanthus occidentalis

Saplings and Shrubs

Planera aquatica

Cephalanthus occidentalis

Fraxinus caroliniana

Woody Vines

None present

Herbs and Woody Seedlings

None present

$\begin{array}{rrrr}36.0 & 30.9 & 73.4 & 140.3 \\ 28.0 & 41.9 & 21.9 & 91.8 \\ 20.0 & 20.0 & 3.8 & 43.8 \\ 8.0 & 3.6 & 0.5 & 12.1 \\ 8.0 & 3.6 & 0.4 & \frac{12.0}{300.0}\end{array}$

\begin{tabular}{rr}
44.4 & 54.5 \\
33.3 & 27.3 \\
22.3 & 18.2 \\
\hline 100.0 & 100.0
\end{tabular}

38.4

34.2

137.3

94.8

$\frac{37.4}{100.0}$

\section{Zone 3}

\section{Trees}

Acer drummondi i

Fraxinus caroliniana

13.8

20.7

10.3

17.3

13.8

10.3

Taxodium distichum

Carya aquatica

Liquidambar styraciflua

Planera aquatica

6.9

$\frac{6.9}{100.0}$

25.9

19.3

12.9

12.9

3.2

12.9

6.5

3.2
30.9

21.8

90.1

12.7

10.9

5.5

3.6

$\frac{5.5}{100.0}$

35.5

23.7

16.1

7.5

8.6

4.3

2.1

1.1
23.9

8.0

28.4

17.5

2.5

10.3

8.6

$\frac{0.8}{100.0}$

40.5

22.7

11.8

9.4

9.8

2.7

1.2

1.3
68.6

50.5

47.8

57.5

27.2

26.1

19.1

13.2

$\frac{13.2}{300.0}$

Carya aquatica 
Table D-2--continued

\begin{tabular}{|c|c|c|c|c|}
\hline Species & $\begin{array}{c}\text { Percent } \\
\text { Relative } \\
\text { Frequency }\end{array}$ & $\begin{array}{r}\text { Percent } \\
\text { Relative } \\
\text { Density } \\
\end{array}$ & $\begin{array}{r}\text { Percent } \\
\text { Relative } \\
\text { Dominance } \\
\end{array}$ & $\begin{array}{c}\text { Importance } \\
\text { Value } \\
\end{array}$ \\
\hline Planera aquatica & $\frac{3.2}{100.0}$ & $\frac{1.1}{100.0}$ & $\frac{0.6}{100.0}$ & $\frac{4.9}{300.0}$ \\
\hline \multicolumn{5}{|l|}{ Woody Vines } \\
\hline Vitis palmata & 37.5 & 33.3 & 40.2 & 111.0 \\
\hline Campsis radicans & 25.0 & 33.3 & 48.2 & 106.5 \\
\hline Ampelopsis arborea & 35.0 & 22.3 & 9.8 & 57.1 \\
\hline \multirow[t]{2}{*}{ Brunnichia cirrhosa } & 12.5 & 11.1 & 1.8 & 25.4 \\
\hline & 100.0 & 100.0 & 100.0 & 300.0 \\
\hline \multicolumn{5}{|l|}{ Herbs and Woody Seedlings } \\
\hline Quercus laurifolia & 21.1 & -- & 40.8 & 61.9 \\
\hline Justicia ovata & 21.0 & -- & 13.7 & 34.7 \\
\hline Saururus cernuus & 8.1 & -- & 12.6 & 20.7 \\
\hline Lysimachia radicans & 8.1 & - & 6.2 & 14.3 \\
\hline Quercus lyrata & 8.1 & -- & 4.1 & 12.2 \\
\hline Smilax walteri & 3.2 & -- & 6.6 & 9.8 \\
\hline Styrax americana & 4.8 & - & 3.3 & 8.1 \\
\hline Brunnichia cirrhosa & 4.8 & -- & 3.3 & 8.1 \\
\hline Leersia sp. & 1.6 & - & 2.5 & 4.1 \\
\hline Ampelopsis arborea & 1.6 & -- & 2.5 & 4.1 \\
\hline Fraxinus caroliniana & 3.2 & - & 0.8 & 4.0 \\
\hline Vitis palmata & 1.6 & - & 0.4 & 2.0 \\
\hline Toxicodendron radicans & 1.6 & -- & 0.4 & 2.0 \\
\hline Diodia virginiana & 1.6 & -- & 0.4 & 2.0 \\
\hline Crataegus viridis & 1.6 & -- & 0.4 & 2.0 \\
\hline Cephalanthus occidentalis & 1.6 & - & 0.4 & 2.0 \\
\hline Campsis radicans & 1.6 & -- & 0.4 & 2.0 \\
\hline Aster sp. & 1.6 & - & 0.4 & 2.0 \\
\hline Asclepias perennis & 1.6 & -- & 0.4 & 2.0 \\
\hline \multirow[t]{3}{*}{ Acer drummondii } & 1.6 & -- & 0.4 & 2.0 \\
\hline & 100.0 & & 100.0 & 200.0 \\
\hline & Zone & & & \\
\hline \multicolumn{5}{|l|}{ Trees } \\
\hline Carpinus caroliniana & 30.0 & 51.3 & 11.6 & 92.9 \\
\hline Liquidambar styraciflua & 30.0 & 23.6 & 29.4 & 83.0 \\
\hline Quercus michauxii & 10.1 & 6.9 & 26.9 & 43.9 \\
\hline Nyssa sylvatica & 6.7 & 2.8 & 22.5 & 32.0 \\
\hline Ulmus americana & 3.3 & 2.8 & 6.2 & 12.3 \\
\hline Ilex decidua & 6.7 & 4.2 & 0.6 & 11.5 \\
\hline Ilex opaca & 3.3 & 2.8 & 1.4 & 7.5 \\
\hline Acer drummondii & 3.3 & 2.8 & 0.8 & 6.9 \\
\hline Carya aquatica & 3.3 & 1.4 & 0.4 & 5.1 \\
\hline \multirow{2}{*}{ Crataegus viridis } & 3.3 & 1.4 & 0.2 & 4.9 \\
\hline & $\overline{100.0}$ & $\overline{100.0}$ & $\overline{100.0}$ & $\overline{300.0}$ \\
\hline
\end{tabular}


Table D-2--continued

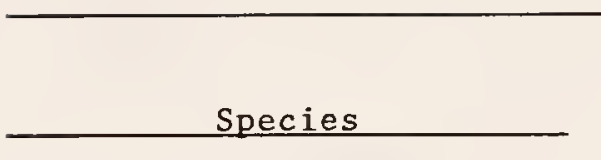

$\begin{array}{ccc}\text { Percent } & \text { Percent } & \text { Percent } \\ \text { Relative } & \text { Relative } & \text { Relative } \\ \text { Frequency } & \text { Density } & \text { Dominance }\end{array}$

Importance

Saplings and Shrubs

Carpinus caroliniana

Ilex decidua

Crataegus viridis

Sebastiania fruticosa

$\begin{array}{rrrr}49.9 & 61.8 & 64.9 & 176.6 \\ 38.9 & 34.0 & 32.4 & 105.3 \\ 5.6 & 2.1 & 2.0 & 9.7 \\ 5.6 & 2.1 & 0.7 & \frac{8.4}{300.0}\end{array}$

Woody Vines

Vitis palmata

Berchemia scandens

Toxicodendron radicans

$V$ itis rotundifolia

Campsis radicans

Cocculus carolinus

Ampelops is arborea

$\begin{array}{rr}32.2 & 19.3 \\ 22.6 & 29.6 \\ 9.7 & 27.4 \\ 19.4 & 17.0 \\ 9.7 & 4.5 \\ 3.2 & 1.1 \\ 3.2 & \frac{1.1}{100.0}\end{array}$

$$
\begin{array}{r}
24.9 \\
18.8 \\
25.4 \\
22.7 \\
5.0 \\
1.6 \\
1.6 \\
\hline 100.0
\end{array}
$$

76.4

71.0

62.5

59.1

129.2

5. 9

5.9

Herbs and Woody Seedlings

Berchemia scandens
Mitchella repens
Vitis palmata
Sebastiania fruticosa
Justicia ovata
Toxicodendron radicans
Ulmus americana
Smilax walteri
Quercus laurifolia
Quercus michauxii
Nyssa sylvatica
Carpinus caroliniana
Aster sp.
Vernonia gigantea
Lysimachia radicans
Diodia virginiana
Bignonia capreolata
Liquidambar styraciflua
Celtis laevigata
Viola missouriensis
Polygonum virginianum
Parthenocissus quinquefolia
Campsis radicans
Botrychium sp.

\begin{tabular}{rrrr}
15.2 & - & 25.0 & 40.2 \\
8.2 & - & 13.8 & 22.0 \\
9.6 & - & 7.5 & 17.1 \\
4.2 & - & 11.9 & 16.1 \\
6.9 & - & 8.9 & 15.8 \\
6.9 & - & 4.4 & 11.3 \\
5.6 & - & 1.7 & 7.3 \\
5.6 & - & 1.7 & 7.3 \\
5.6 & - & 12.7 & 7.3 \\
2.8 & - & 3.1 & 5.9 \\
2.8 & - & 3.1 & 5.9 \\
4.2 & - & 1.3 & 5.5 \\
4.2 & - & 1.3 & 5.5 \\
1.4 & - & 2.7 & 4.1 \\
1.4 & - & 2.7 & 4.1 \\
1.4 & - & 2.7 & 4.1 \\
1.4 & - & 2.7 & 4.1 \\
2.8 & - & 0.9 & 3.7 \\
2.8 & - & 0.9 & 3.7 \\
1.4 & -- & 0.4 & 1.8 \\
1.4 & - & 0.4 & 1.8 \\
1.4 & -- & 0.4 & 1.8 \\
1.4 & -- & 0.4 & 1.8 \\
1.4 & -- & 0.4 & 1.8 \\
\hline 100.0 & & 100.0 & 200.0
\end{tabular}

Trees

Ostrya virginiana

Zone 6

24.9

46.2

9.8

80.9 
Table D-2--continued

\begin{tabular}{|c|c|c|c|c|}
\hline Species & $\begin{array}{l}\text { Percent } \\
\text { Relative } \\
\text { Frequency }\end{array}$ & $\begin{array}{r}\text { Percent } \\
\text { Relative } \\
\text { Density } \\
\end{array}$ & $\begin{array}{c}\text { Percent } \\
\text { Relative } \\
\text { Dominance }\end{array}$ & $\begin{array}{c}\text { Importance } \\
\text { Value } \\
\end{array}$ \\
\hline Fagus grandifolia & 9.4 & 7.7 & 32.4 & 49.5 \\
\hline Quercus alba & 12.5 & 13.5 & 16.2 & 42.2 \\
\hline Quercus nigra & 9.4 & 5.8 & 11.1 & 26.3 \\
\hline Pinus taeda & 9.4 & 5.8 & 10.5 & 25.7 \\
\hline Ilex opaca & 12.5 & 7.7 & 3.0 & 23.2 \\
\hline Cornus florida & 9.4 & 5.7 & 0.7 & 15.8 \\
\hline Liquidambar styraciflua & 6.3 & 3.8 & 4.0 & 14.1 \\
\hline Carya glabra & 3.2 & 1.9 & 6.5 & 11.5 \\
\hline \multirow{2}{*}{ Quercus phellos } & 3.1 & 1.9 & 5.8 & 10.8 \\
\hline & 100.0 & 100.0 & 100.0 & 300.0 \\
\hline \multicolumn{5}{|l|}{ Saplings and Shrubs } \\
\hline Vaccinium elliottii & 16.4 & 30.8 & 18.3 & 65.5 \\
\hline Ilex opaca & 14.4 & 17.1 & 13.7 & 45.2 \\
\hline Ostyra virginiana & 14.4 & 11.4 & 18.1 & 43.9 \\
\hline Ilex vomitoria & 6.1 & 8.0 & 6.6 & 20.7 \\
\hline Cornus florida & 8.2 & 4.5 & 7.5 & 20.2 \\
\hline Vaccinium arboreum & 6.1 & 4.5 & 6.5 & 17.1 \\
\hline Nyssa sylvatica & 4.1 & 4.5 & 6.5 & 15.1 \\
\hline Chionanthus virginicus & 6.1 & 3.4 & 3.8 & 13.3 \\
\hline Quercus phellos & 4.1 & 2.3 & 3.9 & 10.3 \\
\hline Liquidambar styraciflua & 4.1 & 2.3 & 1.0 & 7.4 \\
\hline Fagus grandifolia & 2.0 & 2.3 & 2.9 & 7.2 \\
\hline Symplocos tinctoria & 2.0 & 2.3 & 1.4 & 5.7 \\
\hline Sassafras albidum & 2.0 & 1.2 & 2.0 & 5.1 \\
\hline Carpinus caroliniana & 2.0 & 1.1 & 2.0 & 5.1 \\
\hline Acer rubrum & 2.0 & 1.1 & 2.0 & 5.1 \\
\hline Quercus laurifolia & 2.0 & 1.1 & 1.6 & 4.7 \\
\hline Aralia spinosa & 2.0 & 1.1 & 1.6 & 4.7 \\
\hline \multirow[t]{2}{*}{ Quercus alba } & 2.0 & 1.1 & 0.6 & 3.7 \\
\hline & $\overline{100.0}$ & $\overline{100.0}$ & $\overline{100.0}$ & $\overline{300.0}$ \\
\hline \multicolumn{5}{|l|}{ Woody Vines } \\
\hline Vitis rotundifolia & 71.4 & 77.8 & 81.0 & 230.2 \\
\hline Gelsemium sempervirens & 14.3 & 11.1 & 17.1 & 42.5 \\
\hline \multirow[t]{2}{*}{ Smilax rotundifolia } & 14.3 & 11.1 & 1.9 & 27.3 \\
\hline & $\overline{100.0}$ & $\overline{100.0}$ & $\overline{100.0}$ & $\overline{300.0}$ \\
\hline \multicolumn{5}{|l|}{ Herbs and Woody Seedlings } \\
\hline Mitchella repens & 11.8 & - & 19.5 & 31.3 \\
\hline Quercus nigra & 13.8 & - - & 15.7 & 29.5 \\
\hline Smilax pumila & 8.8 & - & 15.3 & 24.1 \\
\hline Sebastiania fruticosa & 5.9 & -. & 9.0 & 14.9 \\
\hline Chasmanthium laxum & 5.9 & - & 9.0 & 14.9 \\
\hline Carex sp. & 5.0 & - & 4.4 & 9.4 \\
\hline Ostyra virginiana & 6.8 & - & 2.0 & 8.8 \\
\hline Vitis rotundifolia & 5.0 & - & 2.9 & 7.9 \\
\hline
\end{tabular}


Table D-2--continued

\begin{tabular}{|c|c|c|c|c|}
\hline Species & \begin{tabular}{l}
\multicolumn{1}{c}{ Percent } \\
Relative \\
Frequency
\end{tabular} & $\begin{array}{r}\text { Percent } \\
\text { Relative } \\
\text { Density } \\
\end{array}$ & $\begin{array}{c}\text { Percent } \\
\text { Relative } \\
\text { Dominance }\end{array}$ & $\begin{array}{c}\text { Importance } \\
\text { Value }\end{array}$ \\
\hline $\begin{array}{l}\text { Dichanthelium commutatum } \\
\text { Ilex vomitoria } \\
\text { Smilax rotundifolia } \\
\text { Carya glabra } \\
\text { Diospyros virginiana } \\
\text { Chasmanthium sessiliflorum } \\
\text { Aralia spinosa } \\
\text { Vaccinium arboreum } \\
\text { Quercus phellos } \\
\text { Callicarpa americana } \\
\text { Bignonia capreolata } \\
\text { Acer rubrum } \\
\text { Viburnum dentatum } \\
\text { Sassafras albidum } \\
\text { Toxicodendron radicans } \\
\text { Prunus umbellata } \\
\text { Paspalum sp. } \\
\text { Liquidambar styraciflua } \\
\text { Fagus grandifolia } \\
\text { Crataegus marshalli } \\
\text { Chionanthus virginicus } \\
\text { Aristolochia serpentaria }\end{array}$ & $\begin{array}{l}4.0 \\
2.0 \\
5.0 \\
3.0 \\
1.0 \\
1.0 \\
1.0 \\
2.0 \\
2.0 \\
2.0 \\
2.0 \\
2.0 \\
1.0 \\
1.0 \\
1.0 \\
1.0 \\
1.0 \\
1.0 \\
1.0 \\
1.0 \\
1.0 \\
1.0 \\
100.0\end{array}$ & $\begin{array}{l}-- \\
-- \\
-- \\
-- \\
-- \\
-- \\
-- \\
-- \\
-- \\
-- \\
-- \\
-- \\
-- \\
-- \\
-- \\
-- \\
-- \\
-- \\
-- \\
-- \\
-- \\
--\end{array}$ & $\begin{array}{r}2.6 \\
4.5 \\
1.4 \\
2.3 \\
1.8 \\
1.8 \\
1.8 \\
0.6 \\
0.6 \\
0.6 \\
0.6 \\
0.6 \\
0.3 \\
0.3 \\
0.3 \\
0.3 \\
0.3 \\
0.3 \\
0.3 \\
0.3 \\
0.3 \\
0.3 \\
100.0\end{array}$ & $\begin{array}{r}6.6 \\
6.5 \\
6.4 \\
5.3 \\
2.8 \\
2.8 \\
2.8 \\
2.6 \\
2.6 \\
2.6 \\
2.6 \\
2.6 \\
1.3 \\
1.3 \\
1.3 \\
1.3 \\
1.3 \\
1.3 \\
1.3 \\
1.3 \\
1.3 \\
1.3 \\
200.0\end{array}$ \\
\hline
\end{tabular}


Table D-3

Importance Values for Species Occurring at Site 3 . Arranged by Zone and Vegetation Layer

\begin{tabular}{|c|c|c|c|c|}
\hline Species & $\begin{array}{l}\text { Percent } \\
\text { Relative } \\
\text { Frequency }\end{array}$ & $\begin{array}{r}\text { Percent } \\
\text { Relative } \\
\text { Density }\end{array}$ & \begin{tabular}{l}
\multicolumn{1}{c}{ Percent } \\
Relative \\
Dominance
\end{tabular} & $\begin{array}{c}\text { Importance } \\
\text { Value }\end{array}$ \\
\hline
\end{tabular}

Zone 2

\section{$\underline{\text { Trees }}$}

Salix nigra

Cephalanthus occidentalis

Taxodium distichum

Planera aquatica

Saplings and Shrubs

Salix nigra
Planera aquatica
Forestiera acuminata
Cephalanthus occidentalis
Taxodium distichum

Woody Vines

Ipomoea wrightii

Ipomoea lacunosa

Cardiospermum halicacabum

Herbs and Woody Seedlings

Forestiera acuminata

Ipomoea wrightii

Cardiospermum halicacabum

Boehmeria cylindrica

Aster simplex

Cyperus erythrorhizos

Amaranthus rudis

Planera aquatica

Acalypha rhomboidea

Ricciocarpus natans

Cephalanthus occidentalis

Campsis radicans

Paspalum fluitans

Rorippa islandica

Ipomoea lacunosa

Sesbania exaltata

Melothria pendula

Diodia virginiana

Vitis palmata

Polygonum hydropiperoides

$\begin{array}{r}76.9 \\ 7.7 \\ 7.7 \\ 7.7 \\ \hline 100.0\end{array}$

$\begin{array}{r}94.6 \\ 3.6 \\ 0.9 \\ 0.9 \\ \hline 100.0\end{array}$

97.1

1.5

1.0

$\frac{0.4}{100.0}$

\begin{tabular}{rr}
62.6 & 88.3 \\
18.8 & 3.2 \\
6.2 & 6.5 \\
6.2 & 1.3 \\
6.2 & 0.7 \\
\hline 100.0 & 100.0
\end{tabular}

93.2

2.2

3.9

0.5

$\frac{0.2}{100.0}$

\begin{tabular}{rr}
46.1 & 75.5 \\
30.8 & 15.6 \\
23.1 & 8.9 \\
\hline 100.0 & 100.0
\end{tabular}

73.6

17.8

$\frac{8.6}{100.0}$

195.2

64.2

$\frac{40.6}{300.0}$

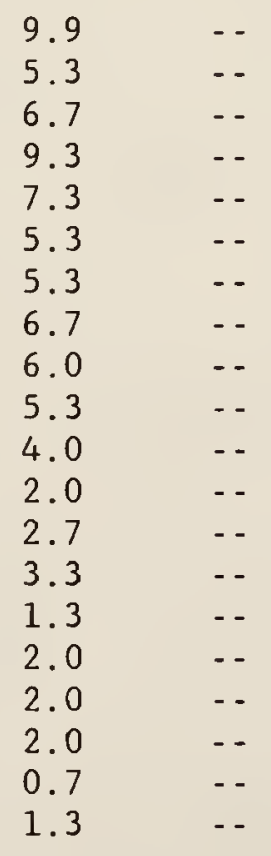

$\begin{array}{rr}19.1 & 29.0 \\ 17.2 & 22.5 \\ 11.5 & 18.2 \\ 7.5 & 16.8 \\ 5.5 & 12.8 \\ 6.0 & 11.3 \\ 6.0 & 11.3 \\ 2.6 & 9.3 \\ 2.6 & 8.6 \\ 2.1 & 7.4 \\ 1.5 & 5.5 \\ 3.5 & 5.5 \\ 2.4 & 5.1 \\ 1.3 & 4.6 \\ 1.9 & 3.2 \\ 0.8 & 2.8 \\ 0.8 & 2.8 \\ 0.8 & 2.8 \\ 1.6 & 2.3 \\ 0.5 & 1.8\end{array}$


Table D-3--continued

\begin{tabular}{|c|c|c|c|c|}
\hline Species & $\begin{array}{l}\text { Percent } \\
\text { Relative } \\
\text { Frequency }\end{array}$ & $\begin{array}{r}\text { Percent } \\
\text { Relative } \\
\text { Density } \\
\end{array}$ & \begin{tabular}{l}
\multicolumn{1}{c}{ Percent } \\
Relative \\
Dominance
\end{tabular} & $\begin{array}{c}\text { Importance } \\
\text { Value }\end{array}$ \\
\hline Justicia ovata & 1.3 & - & 0.5 & 1.8 \\
\hline Echinodorus cordifolius & 1.3 & -- & 0.5 & 1.8 \\
\hline Commelina communis & 1.3 & - & 0.5 & 1.8 \\
\hline Taxodium distichum & 0.7 & - & 0.3 & 1.0 \\
\hline Spermacoce glabra & 0.7 & - & 0.3 & 1.0 \\
\hline Sida sp. & 0.7 & -- & 0.3 & 1.0 \\
\hline Salix nigra & 0.7 & -- & 0.3 & 1.0 \\
\hline Paspalum urvillei & 0.7 & -- & 0.3 & 1.0 \\
\hline Nyssa aquatica & 0.7 & -- & 0.3 & 1.0 \\
\hline Ludwigia decurrens & 0.7 & $\cdots$ & 0.3 & 1.0 \\
\hline Heliotropium indicum & 0.7 & -- & 0.3 & 1.0 \\
\hline Eragrostis hypnoides & 0.7 & -- & 0.3 & 1.0 \\
\hline Celtis laevigata & 0.7 & - & 0.3 & 1.0 \\
\hline \multirow[t]{2}{*}{ Brunnichia cirrhosa } & 0.7 & $\cdots$ & 0.3 & 1.0 \\
\hline & $\overline{100.0}$ & & $\overline{100.0}$ & $\overline{200.0}$ \\
\hline
\end{tabular}

Zone 3

\section{Trees}

Forestiera acuminata

Carya aquatica

Acer negundo

Quercus lyrata

Celtis laevigata

Gleditsia aquatica

Fraxinus pennsylvanica

Planera aquatica

Diospyros virginiana

Saplings and Shrubs

Acer negundo

Forestiera acuminata

Fraxinus pennesylvanica

Celtis laevigata

Carya aquatica

Ulmus americana

Woody Vines

Cocculus carolinus

Toxicodendron radicans

Ampelops is arborea

Vitis riparia

\begin{tabular}{rr}
27.7 & 32.8 \\
20.7 & 20.7 \\
17.3 & 24.1 \\
17.3 & 8.6 \\
3.4 & 5.2 \\
3.4 & 1.7 \\
3.4 & 3.5 \\
3.4 & 1.7 \\
3.4 & 1.7 \\
\hline 100.0 & 100.0
\end{tabular}

29.2

25.0

20.9

12.5

8.3

$\frac{4.1}{100.0}$

40.0

10.0

20.0

10.0
40.6

25.3

23.1

6.6

3. 3

$\frac{1.1}{100.0}$

40.0

18.8

17.5

13.8
20.3

28.7

3.1

18.0

24.2

3.9

0.9

0.5

$\frac{0.4}{100.0}$

45.4

20.2

20.9

7.6

4.4

$\frac{1.5}{100.0}$

26.4

39.0

14.5

15.4
80.8

70.1

44.5

43.9

32.8

9.0

7.8

5.6

5.5

300.0

115.2

70.5

64.9

26.7

16.0

$\frac{6.7}{300.0}$

106.4

67.8

52.0

39.2 
$\underline{\text { Table D-3--continued }}$

\begin{tabular}{|c|c|c|c|c|}
\hline Species & $\begin{array}{c}\text { Percent } \\
\text { Relative } \\
\text { Frequency }\end{array}$ & $\begin{array}{r}\text { Percent } \\
\text { Relative } \\
\text { Density } \\
\end{array}$ & $\begin{array}{r}\text { Percent } \\
\text { Relative } \\
\text { Dominance } \\
\end{array}$ & $\begin{array}{c}\text { Importance } \\
\text { Value }\end{array}$ \\
\hline Brunnichia cirrhosa & 10.0 & 6.2 & 2.7 & 18.9 \\
\hline Parthenocissus quinquefolia & 5.0 & 2.5 & 1.2 & 8.7 \\
\hline \multirow[t]{2}{*}{ Trachelospermum difforme } & 5.0 & 1.2 & 0.8 & 7.0 \\
\hline & 100.0 & 100.0 & 100.0 & 300.0 \\
\hline \multicolumn{5}{|l|}{ Herbs and Woody Seedlings } \\
\hline Forestiera acuminata & 34.1 & - - & 34.4 & 68.5 \\
\hline Cocculus carolinus & 17.0 & -- & 21.6 & 38.6 \\
\hline Vitis riparia & 10.6 & - & 7.7 & 18.3 \\
\hline Cephalanthus occidentalis & 2.1 & $\cdots$ & 11.5 & 13.6 \\
\hline Brunnichia cirrhosa & 6.4 & - & 6.2 & 12.6 \\
\hline Ampelops is arborea & 4.3 & -- & 5.4 & 9.7 \\
\hline Acalypha rhomboidea & 4.3 & -- & 5.4 & 9.7 \\
\hline Sida sp. & 4.3 & -- & 1.5 & 5.8 \\
\hline Boehmeria cylindrica & 4.3 & - & 1.5 & 5.8 \\
\hline Sassafras albidum & 2.1 & -- & 0.8 & 2.9 \\
\hline Ipomoea lacunosa & 2.1 & -- & 0.8 & 2.9 \\
\hline Celtis laevigata & 2.1 & - & 0.8 & 2.9 \\
\hline Amaranthus rudis & 2.1 & $\cdots$ & 0.8 & 2.9 \\
\hline \multirow[t]{3}{*}{ Acer rubrum } & 2.1 & - & 0.8 & 2.9 \\
\hline & 100.0 & & $\overline{100.0}$ & $\overline{200.0}$ \\
\hline & Zone 4 & & & \\
\hline \multicolumn{5}{|l|}{ Trees } \\
\hline$\overline{\text { Quercus lyrata }}$ & 29.4 & 20.8 & 84.2 & 134.4 \\
\hline Acer negundo & 35.2 & 54.1 & 11.2 & 100.5 \\
\hline Liquidambar styraciflua & 11.8 & 8.3 & 0.7 & 20.8 \\
\hline Ulmus americana & 5.9 & 4.2 & 2.3 & 12.4 \\
\hline Carya aquatica & 5.9 & 4.2 & 1.0 & 11.1 \\
\hline Morus rubra & 5.9 & 4.2 & 0.3 & 10.4 \\
\hline \multirow[t]{2}{*}{ Fraxinus pennsylvanica } & 5.9 & 4.2 & 0.3 & 10.4 \\
\hline & $\overline{100.0}$ & $\overline{100.0}$ & $\overline{100.0}$ & $\overline{300.0}$ \\
\hline \multicolumn{5}{|l|}{ Saplings and Shrubs } \\
\hline Carya aquatica & 24.3 & 43.7 & 35.8 & 103.8 \\
\hline Acer negundo & 21.2 & 33.3 & 41.7 & 96.2 \\
\hline Ulmus americana & 12.1 & 6.3 & 5.8 & 24.2 \\
\hline Celtis laevigata & 12.1 & 6.3 & 5.6 & 24.0 \\
\hline Fraxinus pennsylvanica & 12.1 & 4.8 & 6.0 & 22.9 \\
\hline Liquidambar styraciflua & 6.1 & 2.4 & 2.0 & 10.5 \\
\hline Acer drummondii & 6.1 & 1.6 & 1.6 & 9.3 \\
\hline Cornus drummondii & 3.0 & 0.8 & 0.9 & 4.7 \\
\hline \multirow[t]{2}{*}{ Quercus lyrata } & 3.0 & 0.8 & 0.6 & 4.4 \\
\hline & $\overline{100.0}$ & $\overline{100.0}$ & $\overline{100.0}$ & $\overline{300.0}$ \\
\hline
\end{tabular}


Table D-3--continued

\begin{tabular}{|c|c|c|c|c|}
\hline Species & $\begin{array}{l}\text { Percent } \\
\text { Relative } \\
\text { Frequency }\end{array}$ & $\begin{array}{r}\text { Percent } \\
\text { Relative } \\
\text { Density } \\
\end{array}$ & $\begin{array}{l}\text { Percent } \\
\text { Relative } \\
\text { Dominance }\end{array}$ & $\begin{array}{c}\text { Importance } \\
\text { Value } \\
\end{array}$ \\
\hline \multicolumn{5}{|l|}{ Woody Vines } \\
\hline Toxicodendron radicans & 31.1 & 72.5 & 92.0 & 195.6 \\
\hline Cocculus carolinus & 21.9 & 14.1 & 3.1 & 39.1 \\
\hline Trachelospermum difforme & 12.5 & 4.8 & 0.7 & 18.0 \\
\hline Berchemia scandens & 9.4 & 2.6 & 1.5 & 13.5 \\
\hline Ampelopsis arborea & 6.3 & 2.2 & 0.9 & 9.4 \\
\hline Vitis rotundifolia & 6.3 & 1.3 & 1.2 & 8.8 \\
\hline Brunnichia cirrhosa & 6.3 & 1.7 & 0.3 & 8.3 \\
\hline Campsis radicans & 3.1 & 0.4 & 0.2 & 3.7 \\
\hline \multirow[t]{2}{*}{ Smilax rotundifolia } & 3.1 & 0.4 & 0.1 & 3.6 \\
\hline & $\overline{100.0}$ & $\overline{100.0}$ & $\overline{100.0}$ & $\overline{300.0}$ \\
\hline \multicolumn{5}{|l|}{ Herbs and Woody Seedlings } \\
\hline Toxicodendron radicans & 29.8 & - & 74.3 & 104.1 \\
\hline Cocculus carolinus & 14.9 & - & 9.2 & 24.1 \\
\hline Ampelops is arborea & 12.8 & - & 6.0 & 18.8 \\
\hline Trachelospermum difforme & 8.5 & -- & 2.1 & 10.6 \\
\hline Brunnichia cirrhosa & 8.5 & - & 2.1 & 10.6 \\
\hline Ilex decidua & 4.3 & -- & 1.1 & 5.4 \\
\hline Clematis virginiana & 4.3 & - & 1.1 & 5.4 \\
\hline Celtis laevigata & 4.3 & - & 1.1 & 5.4 \\
\hline Vitis rotundifolia & 2.1 & -- & 0.5 & 2.6 \\
\hline Ulmus americana & 2.1 & - & 0.5 & 2.6 \\
\hline Smilax rotundifolia & 2.1 & -- & 0.5 & 2.6 \\
\hline Cephalanthus occidentalis & 2.1 & -- & 0.5 & 2.6 \\
\hline Camps is radicans & 2.1 & - & 0.5 & 2.6 \\
\hline \multirow[t]{3}{*}{ Berchemia scandens } & 2.0 & -- & 0.5 & 2.6 \\
\hline & 100.0 & & $\overline{100.0}$ & 200.0 \\
\hline & \multicolumn{2}{|l|}{ Zone 5} & & \\
\hline \multicolumn{5}{|l|}{ Trees } \\
\hline Liquidambar styraciflua & 31.7 & 34.5 & 68.5 & 134.7 \\
\hline Carya illinoensis & 18.2 & 20.7 & 16.7 & 55.6 \\
\hline Celtis laevigata & 18.2 & 20.7 & 4.9 & 43.8 \\
\hline Quercus shumardii & 9.1 & 6.9 & 6.1 & 22.1 \\
\hline Quercus nigra & 9.1 & 6.9 & 2.7 & 18.7 \\
\hline Ulmus americana & 9.1 & 6.9 & 0.9 & 16.9 \\
\hline \multirow[t]{2}{*}{ Acer negundo } & 4.6 & 3.4 & 0.2 & 8.2 \\
\hline & 100.0 & 100.0 & 100.0 & 300.0 \\
\hline \multicolumn{5}{|l|}{ Saplings and Shrubs } \\
\hline Cornus drummondii & 21.6 & 59.2 & 58.3 & 139.1 \\
\hline Ilex decidua & 17.4 & 15.3 & 15.9 & 48.6 \\
\hline Celtis laevigata & 15.2 & 6.4 & 7.2 & 28.8 \\
\hline U1mus americana & 15.2 & 5.1 & 5.8 & 26.1 \\
\hline Acer negundo & 6.5 & 6.4 & 6.0 & 18.9 \\
\hline
\end{tabular}


Table D-3--continued

\begin{tabular}{|c|c|c|c|c|}
\hline Species & $\begin{array}{c}\text { Percent } \\
\text { Relative } \\
\text { Frequency }\end{array}$ & $\begin{array}{r}\text { Percent } \\
\text { Relative } \\
\text { Density } \\
\end{array}$ & 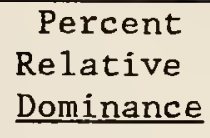 & $\begin{array}{c}\text { Importance } \\
\text { Value }\end{array}$ \\
\hline Cercis canadensis & 6.5 & 1.9 & 1.5 & 9.9 \\
\hline Crataegus viridis & 4.4 & 1.9 & 2.4 & 8.7 \\
\hline Fraxinus pennsylvanica & 4.4 & 1.3 & 0.9 & 6.6 \\
\hline Liquidambar styraciflua & 4.4 & 1.3 & 0.7 & 6.4 \\
\hline Acer rubrum & 2.2 & 0.6 & 1.0 & 3.8 \\
\hline \multirow[t]{2}{*}{ Quercus shumardii } & 2.2 & 0.6 & 0.3 & 3.1 \\
\hline & $\overline{100.0}$ & $\overline{100.0}$ & $\overline{100.0}$ & $\overline{300.0}$ \\
\hline \multicolumn{5}{|l|}{ Woody Vines } \\
\hline Toxicodendron radicans & 29.7 & 82.5 & 89.6 & 201.8 \\
\hline Campsis radicans & 18.5 & 3.4 & 1.6 & 23.5 \\
\hline Berchemia scandens & 14.8 & 5.1 & 1.1 & 21.0 \\
\hline Vitis riparia & 11.1 & 2.8 & 3.5 & 17.4 \\
\hline Vitis rotundifolia & 11.1 & 1.7 & 0.9 & 13.7 \\
\hline Parthenocissus quinquefolia & 7.4 & 2.8 & 1.8 & 12.0 \\
\hline Ampelopsis cordata & 3.7 & 1.1 & 1.4 & 6.2 \\
\hline \multirow[t]{2}{*}{ Brunnichia cirrhosa } & 3.7 & 0.6 & 0.1 & 4.4 \\
\hline & 100.0 & 100.0 & 100.0 & 300.0 \\
\hline \multicolumn{5}{|l|}{ Herbs and Woody Seedlings } \\
\hline Toxicodendron radicans & 11.7 & $-\cdot$ & 37.3 & 49.0 \\
\hline Viola floridana & 7.1 & - & 11.9 & 19.0 \\
\hline Berchemia scandens & 4.5 & - & 9.9 & 14.4 \\
\hline Ulmus americana & 8.4 & - & 3.9 & 12.3 \\
\hline Ampelopsis arborea & 3.8 & - & 8.5 & 12.3 \\
\hline Celtis laevigata & 6.5 & -- & 3.3 & 9.8 \\
\hline Acer negundo & 4.5 & -- & 1.5 & 6.0 \\
\hline Parthenocissus quinquefolia & 2.6 & - & 3.1 & 5.7 \\
\hline Campsis radicans & 2.6 & - & 3.1 & 5.7 \\
\hline Vitis rotundifolia & 3.8 & $-\cdot$ & 1.3 & 5.1 \\
\hline Ageratina altissima & 3.8 & $\cdots$ & 3.1 & 5.7 \\
\hline Liquidambar styraciflua & 3.3 & - & 0.9 & 3.5 \\
\hline Cornus drummondii & 1.3 & - & 2.7 & 4.0 \\
\hline Clematis viorna & 2.6 & - & 0.9 & 3.5 \\
\hline Aster simplex & 2.6 & -- & 0.9 & 3.5 \\
\hline Acalypha rhomboidea & 2.6 & - & 0.9 & 3.5 \\
\hline Smilax rotundifolia & 2.0 & -- & 0.6 & 2.6 \\
\hline Sanicula canadensis & 2.0 & - & 0.6 & 2.6 \\
\hline Oxal is stricta & 2.0 & - & 0.6 & 2.6 \\
\hline Geum canadense & 2.0 & -- & 0.6 & 2.6 \\
\hline Boehmeria cylindrica & 2.0 & - & 0.6 & 2.6 \\
\hline Vitis sp. & 1.3 & - & 0.4 & 1.7 \\
\hline Quercus shumardii & 1.3 & - & 0.4 & 1.7 \\
\hline Polygonum virginianum & 1.3 & - & 0.4 & 1.7 \\
\hline Ilex decidua & 1.3 & -- & 0.4 & 1.7 \\
\hline Eupatorium serotinum & 1.3 & - & 0.4 & 1.7 \\
\hline Brunnichia cirrhosa & 1.3 & - & 0.4 & 1.7 \\
\hline
\end{tabular}


Table D-3--continued

\begin{tabular}{lcccc}
\hline \multicolumn{1}{c}{ Species } & $\begin{array}{c}\text { Percent } \\
\text { Relative }\end{array}$ & $\begin{array}{c}\text { Percent } \\
\text { Relative } \\
\text { Erequency }\end{array}$ & $\begin{array}{c}\text { Percent } \\
\text { Relative } \\
\text { Deminance }\end{array}$ & $\begin{array}{c}\text { Importance } \\
\text { Value }\end{array}$ \\
\cline { 4 - 5 } Vitis riparia & 0.7 & -- & 0.2 & 0.9 \\
Vernonia gigantea & 0.7 & -- & 0.2 & 0.9 \\
Unknown & 0.7 & -- & 0.2 & 0.9 \\
Trachelospermum difforme & 0.7 & -- & 0.2 & 0.9 \\
Rubus trivialis & 0.7 & -- & 0.2 & 0.9 \\
Quercus phellos & 0.7 & -- & 0.2 & 0.9 \\
Quercus nigra & 0.7 & -- & 0.2 & 0.9 \\
Dichanthelium commutatum & 0.7 & -- & 0.2 & 0.9 \\
Mikania scandens & 0.7 & -- & 0.2 & 0.9 \\
Platanthera flava & 0.7 & -- & 0.2 & 0.9 \\
Fraxinus pennsylvanica & 0.7 & -- & 0.2 & 0.9 \\
Forestiera acuminata & 0.7 & -- & 0.2 & 0.9 \\
Clematis virginiana & 0.7 & -- & 0.2 & 0.9 \\
Carex sp. & 0.7 & -- & 0.2 & 0.9 \\
Aster sp. & 0.7 & -- & 0.2 & 0.9 \\
& 100.0 & & 100.0 & 200.0
\end{tabular}

\section{Zone 6}

\section{Trees}

Sassafras albidum

Acer negundo

Liquidambar styraciflua

Quercus nigra

Celtis laevigata

Cercis canadensis

Quercus falcata var. pagodifolia

Carya illinoensis

Saplings and Shrubs

Acer negundo

Liquidambar styraciflua

Sambucus canadensis

Ulmus americana

Ilex decidua

Cercis canadensis

Aralia spinosa

Callicarpa americana

Quercus falcata var. pagodifolia

Celtis laevigata

Diospyros virginiana

Fraxinus pennsylvanica

Morus rubra

Cornus drummondi $i$

$\begin{array}{rrrr}33.3 & 45.4 & 36.6 & 115.3 \\ 14.3 & 15.2 & 22.0 & 51.5 \\ 19.0 & 18.2 & 3.2 & 40.4 \\ 4.8 & 3.0 & 18.4 & 26.2 \\ 4.8 & 3.0 & 11.4 & 19.2 \\ 9.5 & 6.1 & 2.1 & 17.7 \\ 9.5 & 6.1 & 0.6 & 16.2 \\ 4.8 & \frac{3.0}{100.0} & \frac{5.7}{100.0} & \frac{13.5}{300.0}\end{array}$

10.5

43.3

36.2

90.0

14.8

13.8

11.9

11.9

18.4

9.6

47.0

33.4

13.3

8.4

9.3

31.0

7.5

5.4

7.5

3.8

6.4

19.3

5.2

16.5

7.5

4.2

6.0

2.7

6.0

1.5

4.6

16.3

10.9

9.5

$\begin{array}{ll}4.5 & 1.5\end{array}$

3.0

0.8

1.5

1.1

1.5

0.4

1.5

2.2

2.0

7.8

1. 8

5.0

1.2

3.4

0.8

2.9

1.0

2.5 
Table D-3--continued

\begin{tabular}{|c|c|c|c|c|}
\hline Species & $\begin{array}{c}\text { Percent } \\
\text { Relative } \\
\text { Frequency } \\
\end{array}$ & $\begin{array}{r}\text { Percent } \\
\text { Relative } \\
\text { Density } \\
\end{array}$ & $\begin{array}{c}\text { Percent } \\
\text { Relative } \\
\text { Dominance }\end{array}$ & $\begin{array}{c}\text { Importance } \\
\text { Value }\end{array}$ \\
\hline Quercus nigra & 1.5 & 0.4 & 0.4 & 2.3 \\
\hline \multirow[t]{2}{*}{ Ulmus crassifolia } & 1.5 & 0.4 & 0.3 & 2.2 \\
\hline & 100.0 & 100.0 & 100.0 & 300.0 \\
\hline \multicolumn{5}{|l|}{ Woody Vines } \\
\hline Toxicodendron radicans & 26.5 & 69.2 & 71.7 & 167.4 \\
\hline Vitis rotundifolia & 26.5 & 13.6 & 12.7 & 52.8 \\
\hline Vitis riparia & 26.5 & 8.0 & 11.5 & 46.0 \\
\hline Parthenocissus quinquefolia & 14.7 & 8.4 & 3.8 & 26.9 \\
\hline Cocculus carolinus & 2.9 & 0.4 & 0.2 & 3.5 \\
\hline \multirow[t]{2}{*}{ Campsis radicans } & 2.9 & 0.4 & 0.1 & 3.4 \\
\hline & 100.0 & 100.0 & 100.0 & 300.0 \\
\hline \multicolumn{5}{|l|}{ Herbs and Woody Seedlings } \\
\hline Toxicodendron radicans & 8.9 & -- & 30.4 & 39.3 \\
\hline Sanicula canadensis & 9.4 & - & 18.6 & 28.0 \\
\hline Ageratina altissima & 9.9 & - & 13.8 & 23.7 \\
\hline Viola floridana & 9.4 & - & 7.9 & 17.3 \\
\hline Geum canadense & 9.4 & -- & 6.1 & 15.5 \\
\hline Galium circaezans & 6.8 & - & 2.9 & 9.7 \\
\hline Vernonia gigantea & 4.2 & -- & 4.2 & 8.4 \\
\hline Polygonum virginianum & 3.2 & -- & 2.6 & 5.8 \\
\hline Acer negundo & 3.2 & - & 2.2 & 5.4 \\
\hline Vitis rotundifolia & 3.6 & - & 1.5 & 5.1 \\
\hline Platanthera flava & 2.3 & - & 1.9 & 5.1 \\
\hline Parthenocissus quinquefolia & 2.6 & - & 1.3 & 3.9 \\
\hline U1mus americana & 3.2 & -- & 0.5 & 3.7 \\
\hline Smallanthus uvedalia & 2.2 & -- & 1.3 & 3.5 \\
\hline Oxal is stricta & 2.2 & - & 0.3 & 2.5 \\
\hline Carya illinoensis & 1.6 & -- & 0.3 & 1.9 \\
\hline Smilax glauca & 1.0 & -- & 0.2 & 1.2 \\
\hline Rubus trivialis & 1.0 & -- & 0.2 & 1.2 \\
\hline Quercus nigra & 1.0 & - & 0.2 & 1.2 \\
\hline Lactuca sp. & 1.0 & -- & 0.2 & 1.2 \\
\hline Ampelamus albidus & 1.0 & - & 0.2 & 1.2 \\
\hline Cercis canadensis & 1.0 & -- & 0.2 & 1.2 \\
\hline Campsis radicans & 1.0 & - & 0.2 & 1.2 \\
\hline Botrychium virginianum & 1.0 & - & 0.2 & 1.2 \\
\hline Aralia spinosa & 1.0 & - & 0.2 & 1.2 \\
\hline Phytolacca americana & 1.0 & -- & 0.2 & 1.2 \\
\hline Viola sp. & 0.5 & -- & 0.5 & 1.0 \\
\hline Cornus drummondii & 0.5 & - & 0.5 & 1.0 \\
\hline Trachelospermum difforme & 0.5 & - & 0.1 & 0.6 \\
\hline Smilax rotundifolia & 0.5 & - - & 0.1 & 0.6 \\
\hline Sambucus canadensis & 0.5 & - & 0.1 & 0.6 \\
\hline Rubus sp. & 0.5 & - & 0.1 & 0.6 \\
\hline Quercus shumardii & 0.5 & - & 0.1 & 0.6 \\
\hline
\end{tabular}


Table D-3--continued

\begin{tabular}{|c|c|c|c|c|}
\hline Species & $\begin{array}{l}\text { Percent } \\
\text { Relative } \\
\text { Frequency }\end{array}$ & $\begin{array}{r}\text { Percent } \\
\text { Relative } \\
\text { Density } \\
\end{array}$ & 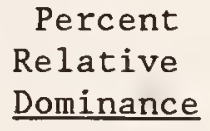 & $\begin{array}{c}\text { Importance } \\
\text { Value }\end{array}$ \\
\hline Parietaria pensylvanica & 0.5 & - & 0.1 & 0.6 \\
\hline Galium aparine & 0.5 & -- & 0.1 & 0.6 \\
\hline Erigeron philadelphicus & 0.5 & - & 0.1 & 0.6 \\
\hline Elytraria caroliniensis & 0.5 & -- & 0.1 & 0.6 \\
\hline Cocculus carolinus & 0.5 & $\cdots$ & 0.1 & 0.6 \\
\hline Aster simplex & 0.5 & - & 0.1 & 0.6 \\
\hline \multirow[t]{2}{*}{ Acalypha rhomboidea } & 0.5 & $\cdots$ & 0.1 & 0.6 \\
\hline & 100.0 & & 100.0 & 200.0 \\
\hline
\end{tabular}


Table D-4

Importance Values for Species Occurring at Site 4. Arranged by Zone and Vegetation Layer

\begin{tabular}{cllll}
\hline & Percent & Percent & Percent & \\
Relative & Relative & Relative & Importance \\
Species & Frequency & Density & Dominance & Value \\
\hline
\end{tabular}

Zone 3

\section{Trees}

Carya aquatica

Quercus lyrata

Diospyros virginiana

Forestiera acuminata

Gleditsia aquatica

Saplings and Shrubs

Forestiera acuminata

Quercus lyrata

Diospyros virginiana

Planera aquatica

Carya aquatica

Cephalanthus occidentalis

Crataegus viridis

Woody Vines

Vitis palmata

Brunnichia cirrohosa

Trachelospermum difforme

Herbs and Woody Seedlings

Quercus lyrata
Brunnichia cirrhosa
Panicum rigidulum
Planera aquatica
Forestiera acuminata
Trachelospermum difforme
Diodia virginiana
Taxodium distichum
Acalypha rhomboidea
Carya aquatica
Cephalanthus occidentalis
Vitis palmata
Styrax americana

$\begin{array}{rrrr}33.3 & 29.1 & 59.6 & 122.0 \\ 25.0 & 32.7 & 23.1 & 80.8 \\ 25.0 & 14.6 & 5.7 & 45.3 \\ 12.5 & 20.0 & 6.7 & 39.2 \\ 4.2 & 3.6 & \frac{4.9}{100.0} & \frac{12.7}{300.0}\end{array}$

$\begin{array}{rrrr}20.7 & 40.7 & 43.3 & 104.7 \\ 27.6 & 17.2 & 19.8 & 64.6 \\ 17.2 & 12.5 & 13.8 & 43.5 \\ 13.8 & 15.6 & 10.4 & 39.8 \\ 6.9 & 6.2 & 7.1 & 20.2 \\ 10.4 & 6.2 & 3.3 & 19.9 \\ 3.4 & 1.6 & \frac{2.3}{100.0} & \frac{7.3}{300.0}\end{array}$

$\begin{array}{rrrr}53.4 & 35.0 & 52.8 & 141.2 \\ 33.3 & 59.8 & 44.6 & 137.7 \\ 13.3 & 5.2 & \frac{2.6}{100.0} & \frac{21.1}{300.0}\end{array}$

\begin{tabular}{rrrr}
28.6 & -- & 34.6 & 63.2 \\
14.3 & -- & 26.1 & 40.4 \\
5.7 & -- & 13.2 & 18.9 \\
8.6 & -- & 6.3 & 14.9 \\
10.0 & -- & 3.9 & 13.9 \\
8.6 & -- & 3.4 & 12.0 \\
7.1 & -- & 2.8 & 9.9 \\
5.7 & -- & 2.2 & 7.9 \\
4.3 & -- & 1.7 & 6.0 \\
1.4 & -- & 3.5 & 4.9 \\
2.9 & -- & 1.1 & 4.0 \\
1.4 & -- & 0.6 & 2.0 \\
1.4 & -- & 0.6 & 2.0 \\
\hline 100.0 & & 100.0 & 200.0
\end{tabular}


Table D-4--continued

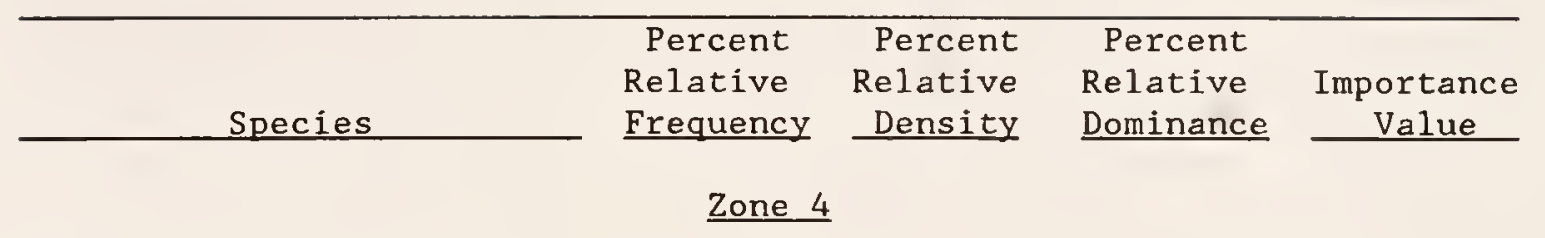

\section{Trees}

Quercus phellos

Carya aquatica

Quercus lyrata

Liquidambar styraciflua

Quercus nuttallii

Crataegus viridis

Diospyros virginiana

Planera aquatica

Saplings and Shrubs

Styrax americana
Ilex decidua
Quercus lyrata
Quercus nuttallii
Diospyros virginiana
Planera aquatica
Cephalanthus occidentalis
Crataegus viridis
Cornus foemina
Quercus phellos
Forestiera acuminata
Carya aquatica

Woody Vines

Vitis riparia

Trachelospermum difforme

Ampelopsis arborea

Berchemia scandens

Campsis radicans

Vitis palmata

Smilax bona-nox

Brunnichia cirrhosa

Smilax glauca

Herbs and Woody Seedlings

\begin{tabular}{rrrr}
16.7 & 16.3 & 33.3 & 66.3 \\
16.7 & 18.6 & 22.5 & 57.8 \\
20.0 & 27.8 & 8.9 & 56.7 \\
13.3 & 11.7 & 23.3 & 48.3 \\
20.0 & 16.3 & 10.8 & 47.1 \\
6.7 & 4.7 & 0.5 & 11.9 \\
3.3 & 2.3 & 0.4 & 6.0 \\
3.3 & 2.3 & 0.3 & 5.9 \\
\hline 100.0 & 100.0 & 100.0 & 300.0
\end{tabular}

\begin{tabular}{rrrr}
20.4 & 58.7 & 46.7 & 125.8 \\
18.2 & 15.6 & 24.0 & 57.8 \\
11.4 & 8.0 & 10.6 & 30.0 \\
9.1 & 5.4 & 6.5 & 21.0 \\
11.4 & 4.3 & 3.5 & 19.2 \\
6.8 & 1.6 & 2.9 & 11.3 \\
6.8 & 1.6 & 1.1 & 9.5 \\
4.5 & 1.1 & 1.8 & 7.4 \\
4.5 & 1.1 & 1.0 & 6.6 \\
2.3 & 1.6 & 1.1 & 5.0 \\
2.3 & 0.5 & 0.4 & 3.2 \\
2.3 & 0.5 & 0.4 & 3.2 \\
\hline 100.0 & 100.0 & 100.0 & 300.0
\end{tabular}

\begin{tabular}{rrrr}
22.5 & 24.8 & 34.6 & 81.9 \\
20.0 & 33.7 & 17.2 & 70.9 \\
15.0 & 21.4 & 18.0 & 54.4 \\
15.0 & 9.7 & 19.6 & 44.3 \\
7.5 & 3.4 & 4.9 & 15.8 \\
7.5 & 2.1 & 3.0 & 12.6 \\
5.0 & 1.4 & 0.9 & 7.3 \\
5.0 & 1.4 & 0.6 & 7.0 \\
2.5 & 2.1 & 1.2 & 5.8 \\
\hline 100.0 & 100.0 & 100.0 & 300.0
\end{tabular}

$\begin{array}{rrrr}10.2 & - & 13.8 & 24.0 \\ 6.9 & - & 14.1 & 22.4 \\ 8.3 & -- & 14.1 & 22.4 \\ 4.8 & -- & 14.1 & 18.9 \\ 9.0 & - & 5.5 & 14.5 \\ 4.8 & - & 6.8 & 11.6\end{array}$


Table D-4--continued

\begin{tabular}{|c|c|c|c|c|}
\hline Species & $\begin{array}{c}\text { Percent } \\
\text { Relative } \\
\text { Frequency }\end{array}$ & $\begin{array}{r}\text { Percent } \\
\text { Relative } \\
\text { Density } \\
\end{array}$ & $\begin{array}{c}\text { Percent } \\
\text { Relative } \\
\text { Dominance }\end{array}$ & $\begin{array}{l}\text { Importance } \\
\text { Value }\end{array}$ \\
\hline Trachelospermum difforme & 6.2 & - & 4.3 & 10.5 \\
\hline Ilex decidua & 6.9 & - & 3.0 & 9.9 \\
\hline Vitis palmata & 5.5 & - - & 4.0 & 9.5 \\
\hline Quercus phellos & 4.8 & - - & 3.7 & 8.5 \\
\hline Brunnichia cirrhosa & 5.5 & - & 2.4 & 7.9 \\
\hline Quercus nuttallii & 4.8 & - & 2.1 & 6.9 \\
\hline Diodia virginiana & 4.8 & - - & 2.1 & 6.9 \\
\hline Smilax glauca & 2.8 & - & 1.2 & 4.0 \\
\hline Forestiera acuminata & 2.8 & - - & 1.2 & 4.0 \\
\hline Acalypha rhomboidea & 2.8 & - & 1.2 & 4.0 \\
\hline Vitis riparia & 2.1 & -- & 0.9 & 3.0 \\
\hline Rubus trivialis & 1.4 & -. & 0.6 & 2.0 \\
\hline Planera aquatica & 1.4 & - & 0.6 & 2.0 \\
\hline Smilax rotundifolia & 0.7 & - & 0.3 & 1.0 \\
\hline Smilax bona-nox & 0.7 & - & 0.3 & 1.0 \\
\hline Panicum rigidulum & 0.7 & - & 0.3 & 1.0 \\
\hline Geum canadense & 0.7 & - - & 0.3 & 1.0 \\
\hline Crataegus viridis & 0.7 & - - & 0.3 & 1.0 \\
\hline \multirow[t]{2}{*}{ Cocculus carolinus } & 0.7 & -- & 0.3 & 1.0 \\
\hline & $\overline{100.0}$ & & $\overline{100.0}$ & $\overline{200.0}$ \\
\hline
\end{tabular}


Table D-5

Importance Values for Species Occurring at Site 5. Arranged by Zone and Vegetation Layer

Species

\begin{tabular}{cccc} 
Percent & Percent & Percent & \\
Relative & Relative & Relative & Importance \\
Frequency & Density & Dominance & Value \\
\cline { 2 - 4 }
\end{tabular}

Zone 3

\section{Trees}

Carya aquatica

Quercus 1yrata

Forestiera acuminata

Taxodium distichum

Quercus phellos

Diospyros virginiana

Saplings and Shrubs

Amorpha fruticosa

Cephalanthus occidentalis

Forestiera acuminata

Diospyros virginiana

Carya aquatica

Crataegus viridis

Planera aquatica

Styrax americana

Ilex decidua

Quercus phellos

Quercus 1yrata

Woody Vines

Trachelospermum difforme

Brunnichia cirrhosa

Vitis palmata

Campsis radicans

Berchemia scandens

Herbs and Woody Seedlings

Quercus lyrata

Arundinaria gigantea

Trachelospermum difforme

Brunnichia cirrhosa

Amorpha fruticosa

Carya aquatica

Forestiera acuminata

Cephalanthus occidentalis

Planera aquatica

Ilex decidua

$\begin{array}{rrrr}45.0 & 54.4 & 37.2 & 136.6 \\ 25.0 & 18.2 & 41.6 & 84.8 \\ 15.0 & 20.5 & 3.2 & 38.7 \\ 5.0 & 2.3 & 17.1 & 24.4 \\ 5.0 & 2.3 & 0.6 & 7.9 \\ 5.0 & \frac{2.3}{100.0} & \frac{0.3}{100.0} & \frac{7.6}{300.0}\end{array}$

\begin{tabular}{rcrr}
16.1 & 28.6 & 22.1 & 66.8 \\
13.2 & 15.5 & 14.3 & 43.0 \\
11.8 & 12.6 & 16.4 & 40.8 \\
13.2 & 10.9 & 14.1 & 38.2 \\
10.3 & 7.21 & 11.7 & 29.2 \\
11.8 & 8.1 & 6.3 & 26.2 \\
5.9 & 5.9 & 4.7 & 16.5 \\
5.9 & 4.5 & 3.6 & 14.0 \\
5.9 & 3.6 & 2.3 & 11.8 \\
4.4 & 2.7 & 3.5 & 10.6 \\
1.5 & 0.4 & 1.0 & 2.9 \\
\hline 100.0 & 100.0 & 100.0 & 300.0
\end{tabular}

$\begin{array}{r}31.3 \\ 31.3 \\ 24.9 \\ 9.4 \\ 3.1 \\ \hline 100.0\end{array}$

71.3

59.7

162.3

13.1

13.6

1.6

17.5

16.7

61.9

55.2

4.7

15.7

$\frac{0.4}{100.0}$

$\frac{1.4}{100.0}$

$\frac{4.9}{300.0}$

11.7

21.8

33.5

10.7

22.5

33.2

11.7

16.4

28.1

5. 7

14.0

5. 5

13.2

5.3

12.4

4.7

10.6

5.9

3.7

9.0

1.9

7.8

5.9

1.5

6.2 
Table D-5--continued

\begin{tabular}{|c|c|c|c|c|}
\hline Species & $\begin{array}{l}\text { Percent } \\
\text { Relative } \\
\text { Frequency }\end{array}$ & $\begin{array}{r}\text { Percent } \\
\text { Relative } \\
\text { Density } \\
\end{array}$ & $\begin{array}{c}\text { Percent } \\
\text { Relative } \\
\text { Dominance } \\
\end{array}$ & $\begin{array}{c}\text { Importance } \\
\text { Value }\end{array}$ \\
\hline Crataegus viridis & 3.0 & -- & 3.0 & 6.0 \\
\hline Campsis radicans & 2.4 & - - & 1.8 & 4.2 \\
\hline Vitis palmata & 2.4 & - & 0.8 & 3.2 \\
\hline Leersia oryzoides & 2.4 & -- & 0.8 & 3.2 \\
\hline Styrax americana & 1.8 & - - & 0.6 & 2.4 \\
\hline Diospyros virginiana & 0.6 & - - & 1.2 & 1.8 \\
\hline Quercus phellos & 1.2 & -- & 0.4 & 1.6 \\
\hline Panicum rigidulum & 1.2 & - & 0.4 & 1.6 \\
\hline Clematis sp. & 1.2 & - - & 0.4 & 1.6 \\
\hline Carex torta & 1.2 & - - & 0.4 & 1.6 \\
\hline Spermacoce glabra & 0.6 & - - & 0.2 & 0.8 \\
\hline Mimosa strigillosa & 0.6 & - - & 0.2 & 0.8 \\
\hline Liquidambar styraciflua & 0.6 & - - & 0.2 & 0.8 \\
\hline Diodia virginiana & 0.6 & -- & 0.2 & 0.8 \\
\hline Bidens frondosa & 0.6 & - & 0.2 & 0.8 \\
\hline \multirow[t]{3}{*}{ Berchemia scandens } & 0.6 & - & 0.2 & 0.8 \\
\hline & $\overline{100.0}$ & & $\overline{100.0}$ & $\overline{200.0}$ \\
\hline & \multicolumn{2}{|l|}{$\underline{\text { Zone } 4}$} & & \\
\hline \multicolumn{5}{|l|}{ Trees } \\
\hline$\overline{\text { Quercus phellos }}$ & 37.1 & 47.2 & 70.8 & 155.1 \\
\hline Liquidambar styraciflua & 14.8 & 11.1 & 8.5 & 34.4 \\
\hline Quercus nuttalii & 14.8 & 11.1 & 8.0 & 33.9 \\
\hline Carya aquatica & 11.1 & 11.1 & 9.7 & 31.9 \\
\hline Taxodium distichum & 7.4 & 8.3 & 0.9 & 16.6 \\
\hline Bumelia lycioides & 7.4 & 5.6 & 1.6 & 14.6 \\
\hline \multirow{2}{*}{ Crataegus viridis } & 7.4 & 5.6 & 0.5 & 13.5 \\
\hline & 100.0 & 100.0 & $\overline{100.0}$ & $\overline{300.0}$ \\
\hline \multicolumn{5}{|l|}{ Saplings and Shrubs } \\
\hline Forestiera acuminata & 33.2 & 59.1 & 64.6 & 156.9 \\
\hline Planera aquatica & 27.8 & 15.4 & 11.5 & 54.7 \\
\hline Diospyros virginiana & 11.1 & 10.3 & 13.0 & 34.4 \\
\hline Crataegus viridis & 11.1 & 5.1 & 5.1 & 21.3 \\
\hline Amorpha fruticosa & 5.6 & 5.1 & 2.2 & 12.9 \\
\hline Taxodium distichum & 5.6 & 2.5 & 2.5 & 10.6 \\
\hline \multirow{2}{*}{ Styrax americana } & 5.6 & 2.5 & 1.1 & 9.2 \\
\hline & 100.0 & 100.0 & 100.0 & 300.0 \\
\hline \multicolumn{5}{|l|}{ Woody Vines } \\
\hline Vitis palmata & 42.8 & 53.4 & 51.6 & 147.8 \\
\hline Vitis riparia & 28.6 & 13.3 & 37.9 & 79.8 \\
\hline & 14.3 & 20.0 & 6.3 & 40.6 \\
\hline \multirow{2}{*}{ Trachelospermum difforme } & 14.3 & 13.3 & 4.2 & 31.8 \\
\hline & 100.0 & 100.0 & 100.0 & 300.0 \\
\hline
\end{tabular}


Table D-5--continued

\begin{tabular}{|c|c|c|c|c|}
\hline Species & \begin{tabular}{c}
\multicolumn{1}{c}{ Percent } \\
Relative \\
Frequency \\
\end{tabular} & $\begin{array}{r}\text { Percent } \\
\text { Relative } \\
\text { Density } \\
\end{array}$ & $\begin{array}{c}\text { Percent } \\
\text { Relative } \\
\text { Dominance } \\
\end{array}$ & $\begin{array}{c}\text { Importance } \\
\text { Value }\end{array}$ \\
\hline \multicolumn{5}{|l|}{ Herbs and Woody Seedlings } \\
\hline Quercus phe11os & 21.7 & -- & 37.6 & 59.3 \\
\hline Brunnichia cirrhosa & 17.1 & - & 14.6 & 31.7 \\
\hline Quercus nuttallii & 10.3 & - & 13.6 & 23.9 \\
\hline Arundinaria gigantea & 9.3 & - & 6.3 & 15.5 \\
\hline Trachelospermum difforme & 8.0 & - & 3.4 & 11.4 \\
\hline Vitis palmata & 4.5 & $\ldots$ & 4.4 & 8.9 \\
\hline Diodia virginiana & 4.5 & - & 1.9 & 6.4 \\
\hline Styrax americana & 3.4 & - & 1.4 & 4.8 \\
\hline Crataegus viridis & 3.4 & - & 1.4 & 4.8 \\
\hline Amorpha fruticosa & 3.4 & - & 1.4 & 4.8 \\
\hline Vitis riparia & 1.1 & - & 3.0 & 4.1 \\
\hline Planera aquatica & 1.1 & $\ldots$ & 3.0 & 4.1 \\
\hline Cephalanthus occidentalis & 1.1 & - & 3.0 & 4.1 \\
\hline Smilax rotundifolia & 2.3 & - & 1.0 & 3.3 \\
\hline Liquidambar styraciflua & 2.3 & - & 1.0 & 3.3 \\
\hline Trifolium sp. & 1.1 & - & 3.0 & 4.1 \\
\hline Lespedeza sp. & 1.1 & - & 0.5 & 1.6 \\
\hline Ilex decidua & 1.1 & -- & 0.5 & 1.6 \\
\hline Carex joorii & 1.1 & - & 0.5 & 1.6 \\
\hline Boehmeria cylindrica & 1.1 & $\ldots$ & 0.5 & 1.6 \\
\hline \multirow[t]{2}{*}{ Bidens frondosa } & 1.1 & - & 0.5 & 1.6 \\
\hline & $\overline{100.0}$ & & $\overline{100.0}$ & $\overline{200.0}$ \\
\hline
\end{tabular}


Table D-6

Importance Values for Species Occurring at Site 6 , Arranged by Zone and Vegetation Layer

\begin{tabular}{llll}
\hline & Percent & Percent & Percent \\
Relative & Relative & Relative Importance \\
Species & Frequency & Density & Dominance \\
\hline
\end{tabular}

Zone 3

\section{$\underline{\text { Trees }}$}

Quercus lyrata

44.5

57.2

55.4

157.1

27.8

17.8

28.6

74.2

Forestiera acuminata

11.1

10.7

1.5

23.3

11.1

10.7

1.0

22.8

Celtis laevigata

$\frac{5.5}{100.0}$

$\frac{3.6}{100.0}$

$\frac{13.5}{100.0}$

$\frac{22.6}{300.0}$

Saplings and Shrubs

Celtis laevigata

Fraxinus pennsylvanica

Forestiera acuminata

Taxodium distichum

Planera aquatica

Ilex decidua

Cephalanthus occidentalis

Woody Vines

Campsis radicans

Trachelospermum difforme

Brunnichia cirrhosa

Ampelopsis arborea

Cocculus carolinus

Vitis riparia

Berchemia scandens

Toxicodendron radicans

Herbs and Woody Seedlings

Campsis radicans
Clematis crispa
Brumnichia cirrhosa
Boehmeria cylindrica
Ampelopsis arborea
Vitis riparia
Trachelospermum difforme
Planera aquatica
Quercus lyrata
Leersia virginica
Forestiera acuminata
Celtis laevigata

$\begin{array}{rrrr}30.0 & 42.8 & 42.8 & 115.6 \\ 35.0 & 32.1 & 28.0 & 95.1 \\ 10.0 & 14.3 & 20.3 & 44.6 \\ 10.0 & 5.4 & 4.5 & 19.9 \\ 5.0 & 1.8 & 2.4 & 9.2 \\ 5.0 & 1.8 & 1.0 & 7.8 \\ 5.0 & 1.8 & \frac{1.0}{100.0} & \frac{7.8}{300.0}\end{array}$

27.1

$18, .9$

18.9

13.5

10.8

5.4

2.7

$\frac{2.7}{100.0}$

11.7

10.2

8.8

10.9

6.6

8.0

8.0

8.8

4.4

3.6

3. 6

2.2
49.4

18.5

16.4

6.2

6.8

1. 3

0.7

$\frac{0.7}{100.0}$
50.8

14.3

15.2

8.2

7.2

1.0

2. 2

$\frac{1.1}{100.0}$
127.3

51.7

50.5

27.9

24.8

7.7

5.6

$\frac{4.5}{300.0}$
40.7

11.8

12.6

6.2

8.5

7.0

4.6

1.9

1.2

0.5

0.5

0.9
52.4

22.0

21.4

17.1

15.1

15.0

12.6

10.7

5.6

4.1

4.1

3. 1 
Table D-6--continued

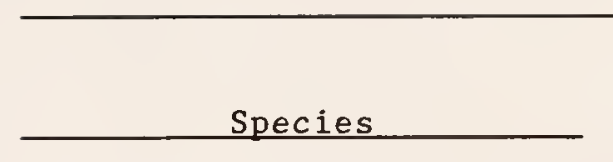

\begin{tabular}{lr}
\multicolumn{1}{c}{ Percent } & Percent \\
Relative & Relative \\
Frequency & Density
\end{tabular}

Percent

Relative Importance

Cocculus carolinus

1.5

$-$

Dominance

Value

Asclepias perennis

Urtica chamaedryoides

Toxicodendron radicans

Cephalanthus occidentalis

Bidens discoidea

$V$ itis cinerea

Taxodium distichum

Senecio glabellus

Fraxinus pennsylvanica

Carya aquatica

Bidens cernua

$\begin{array}{r}1.5 \\ 1.5 \\ 1.5 \\ 1.5 \\ 1.5 \\ 0.5 \\ 0.7 \\ 0.7 \\ 0.7 \\ 0.7 \\ 0.7 \\ 0.7 \\ \hline 100.0\end{array}$

0.8

2.3

1.5

$-$

0.8

2.3

1.5

0.2

1.7

1.5

0.2

1.7

$-$

0.2

1.7

0.5

0.2

1.7

0.7

1.4

0.7

0.1

0.8

0.7

0.1

0.8

0.1

0.8

0.7

90.1

0.8

0.1

$\frac{0.8}{200.0}$

\section{Zone 4}

\section{Trees}

Liquidambar styraciflua
Celtis laevigata
Acer negundo
Ulmus americana
Carya illinoensis
Cercis canadensis
Quercus lyrata
Cornus drummondii
Ilex decidua

$\begin{array}{r}15.5 \\ 23.1 \\ 23.1 \\ 15.4 \\ 7.7 \\ 3.8 \\ 3.8 \\ 3.8 \\ 3.8 \\ \hline 100.0\end{array}$

13.8

43.4

72.7

6.8

60.5

6.6

54.7

11.8

41.1

27.0

40.2

5.5

2.8

2.2

8.8

2.8

1.7

8.3

2.8

0.3

6.9

$\frac{2.8}{100.0}$

$\frac{0.2}{100.0}$

$\frac{6.8}{300.0}$

Saplings and Shrubs

Celtis laevigata

Ulmus americana

21.4

37.7

37.9

97.0

11.9

18.9

22.0

52.8

14.3

12.3

14.9

41.5

11.9

4.7

2.9

19.5

Ilex decidua

9.5

4.7

3.7

17.9

9.5

5.7

2.7

17.9

Liquidambar styraciflua

4.8

5.7

6.5

17.0

7.1

3.8

4.1

15.0

Acer rubrum

3.8

3.3

9.5

2.4

0.9

1.2

4.5

Quercus phellos

0.9

0.4

3.7

Cornus foemina

$\frac{2.4}{100.0}$

$\frac{0.9}{100.0}$

$\frac{0.4}{100.0}$

$\frac{3.7}{300.0}$

Woody Vines

Parthenocissus quinquefolia

36.8

97.1

Smilax rotundifolia

22.7

8.5

48.5

10.3

11.0

20.2

41.5 
Table D-6--continued

\begin{tabular}{|c|c|c|c|c|}
\hline Species & $\begin{array}{c}\text { Percent } \\
\text { Relative } \\
\text { Frequency }\end{array}$ & $\begin{array}{r}\text { Percent } \\
\text { Relative } \\
\text { Density }\end{array}$ & $\begin{array}{c}\text { Percent } \\
\text { Relative } \\
\text { Dominance } \\
\end{array}$ & $\begin{array}{c}\text { Importance } \\
\text { Value }\end{array}$ \\
\hline $\begin{array}{l}\text { Vitis cinerea } \\
\text { Berchemia scandens } \\
\text { Smilax hispida } \\
\text { Ampelopsis arborea } \\
\text { Cocculus carolinus } \\
\text { Brunnichia cirrhosa } \\
\text { Trachelospermum difforme } \\
\text { Smilax bona-nox } \\
\text { Campsis radicans }\end{array}$ & $\begin{array}{r}10.3 \\
10.3 \\
10.3 \\
8.7 \\
6.9 \\
5.2 \\
1.7 \\
1.7 \\
1.7 \\
100.0\end{array}$ & $\begin{array}{r}4.8 \\
4.8 \\
3.4 \\
2.4 \\
2.4 \\
1.4 \\
1.4 \\
0.7 \\
0.3 \\
100.0\end{array}$ & $\begin{array}{r}15.1 \\
6.5 \\
4.4 \\
4.5 \\
2.3 \\
0.6 \\
0.6 \\
0.2 \\
0.3 \\
100.0\end{array}$ & $\begin{array}{r}30.2 \\
21.6 \\
18.1 \\
15.6 \\
11.6 \\
7.2 \\
3.7 \\
2.6 \\
2.3 \\
300.0\end{array}$ \\
\hline \multicolumn{5}{|l|}{ Herbs and Woody Seedlings } \\
\hline $\begin{array}{l}\text { Toxicodendron radicans } \\
\text { Smilax rotundifolia } \\
\text { Parthenocissus avinguefolia }\end{array}$ & $\begin{array}{r}8.5 \\
18.3 \\
11.3\end{array}$ & $\begin{array}{l}\cdots \\
\cdots \\
-\end{array}$ & $\begin{array}{l}24.0 \\
13.7 \\
20.7\end{array}$ & $\begin{array}{l}32.5 \\
32.0 \\
32.0\end{array}$ \\
\hline $\begin{array}{l}\text { Parthenocissus quinquefolia } \\
\text { Urtica chamaedryoides }\end{array}$ & $\begin{array}{l}11.3 \\
11.3\end{array}$ & $\begin{array}{l}\cdots \\
\cdots\end{array}$ & $\begin{array}{l}20.7 \\
14.3\end{array}$ & $\begin{array}{l}32.0 \\
25.6\end{array}$ \\
\hline $\begin{array}{l}\text { Clematis crispa } \\
\text { Rubus trivialis }\end{array}$ & $\begin{array}{r}14.2 \\
4.2\end{array}$ & $\begin{array}{l}-- \\
--\end{array}$ & $\begin{array}{l}4.8 \\
3.9\end{array}$ & $\begin{array}{r}19.0 \\
8.1\end{array}$ \\
\hline Cocculus carolinus & 4.2 & - & 3.9 & 8.1 \\
\hline Boehmeria cylindrica & 4.2 & -- & 3.9 & $\begin{array}{l}8.1 \\
6.3\end{array}$ \\
\hline $\begin{array}{l}\text { Brunnichia cirrhosa } \\
\text { Senecio glabellus }\end{array}$ & $\begin{array}{l}2.8 \\
4.2\end{array}$ & $\begin{array}{l}\cdots \\
\cdots\end{array}$ & $\begin{array}{l}3.5 \\
1.4\end{array}$ & $\begin{array}{l}6.3 \\
5.6\end{array}$ \\
\hline Acalypha rhomboidea & 4.2 & - & 1.4 & 5.6 \\
\hline Aster simplex & 2.8 & - & 1.0 & 3.8 \\
\hline Ulmus americana & 1.4 & - - & 0.5 & 1.9 \\
\hline Trachelospermum difforme & 1.4 & - - & 0.5 & 1.9 \\
\hline Smilax hispida & 1.4 & -. & 0.5 & 1.9 \\
\hline Morus rubra & 1.4 & - - & 0.5 & 1.9 \\
\hline Leersia virginica & 1.4 & - & 0.5 & 1.9 \\
\hline Ilex decidua & 1.4 & - - & 0.5 & 1.9 \\
\hline Celtis laevigata & $\frac{1.4}{100.0}$ & -- & $\frac{0.5}{100.0}$ & $\frac{1.9}{200.0}$ \\
\hline
\end{tabular}


Table D-7

Importance Values for Species Occurring at Site 7. Arranged by Zone and Vegetation Layer

\begin{tabular}{cccc}
\hline & Percent & Percent & Percent \\
Relative & Relative & Relative Importance \\
Species & Frequency & Density & Dominance \\
Value
\end{tabular}

Zone 2

Trees

Taxodium distichum

Nyssa aquatica

Planera aquatica

Ulmus americana

Celtis laevigata

Forestiera acuminata

Saplings and Shrubs

Styrax americana

Cephalanthus occidentalis

Itea virginica

Taxodium distichum

Woody Vines

Berchemia scandens

Brunnichia cirrhosa

Campsis radicans

Herbs and Woody Seedlings

Boehmeria cylindrica

Onoclea sensibilis

Taxodium distichum

Planera aquatica

Forestiera acuminata

Nyssa aquatica

Cephalanthus occidentalis

Brunnichia cirrhosa

Saururus cernuus

Campsis radicans

Asclepias perennis

Vitis vulpina

Leersia sp.

Quercus lyrata

Leersia virginica

Triadenum walteri

Trachelospermum difforme

Styrax americana

$$
\begin{array}{r}
50.0 \\
25.0 \\
10.0 \\
5.0 \\
5.0 \\
5.0 \\
\hline 100.0
\end{array}
$$

16.7

33.3

33.3

$\frac{16.7}{100.0}$

25.0

50.0

$\frac{25.0}{100.0}$

14.4

3.8

17.2

12.5

12.5

9.6

3. 8

3.8

1.9

2.9

12.9

2.9

1.0

1.9

1.9

1.0

1.0

1.0
62.6

21.9

6.2

3. 1

3.1

$\frac{3.1}{100.0}$

50.0

25.0

16.7

$\frac{8.3}{100.0}$

83.4

11.1

$\frac{5.5}{100.0}$

- -

-

- -

- -

- -

-

- -

-.

- .

-.

-

-

$-$

$-$.

$-$

-

-

-.

-.
79.1

20.0

0.4

0.2

0.2

$\frac{0.1}{100.0}$

55.5

20.4

11.1

$\frac{13.0}{100.0}$

95.5

3.0

$\frac{1.5}{100.0}$

28.1

24.6

10.9

4.2

4.2

4.9

4.6

3.0

4.0

2.6

2.3

1.0

2.0

0.6

0.6

0.3

0.3

0.3
191.7

66.9

16.6

8.3

8.3

$\frac{8.2}{300.0}$

122.2

78.7

61.1

$\frac{38.0}{300.0}$

203.9

64.1

32.0

300.0

42.5

28.4

28.1

16.7

16.7

14.5

8.4

6.8

5.9

5.5

4.2

3.9

3.0

2.5

2.5

1.3

1.3

1.3 
Table D-7--continued

Species

\begin{tabular}{lr}
\multicolumn{1}{c}{ Percent } & Percent \\
Relative & Relative \\
Frequency & Density
\end{tabular}

$\begin{array}{cc}\begin{array}{c}\text { Percent } \\ \text { Relative } \\ \text { Dominance }\end{array} & \begin{array}{c}\text { Importance } \\ \text { Value }\end{array} \\ 0.3 & 1.3 \\ 0.3 & 1.3 \\ 0.3 & 1.3 \\ 0.3 & 1.3 \\ 0.3 & \frac{1.3}{200.0}\end{array}$

Smilax rotundifolia

Pluchea camphorata

Nyssa sylvatica

Carya aquatica

Berchemia scandens

\section{Trees}

Planera aquatica

Taxodium distichum

Forestiera acuminata

Quercus lyrata

Carya aquatica

Acer saccharinum

Crataegus viridis

Celtis laevigata

Saplings and Shrubs

Forestiera acuminata

Taxodium distichum

Cephalanthus occidentalis

Planera aquatica

Acer saccharinum

Nyssa aquatica

Celtis laevigata

Salix nigra

Woody Vines

Brunnichia cirrhosa

Cocculus carolinus

Vitis riparia

Ampelops is cordata

Wisteria frutescens

Trachelospermum difforme

Campsis radicans

\begin{tabular}{rrr}
1.0 & - & 0.3 \\
1.0 & $\ldots$ & 0.3 \\
1.0 &.- & 0.3 \\
1.0 & $\cdots$ & 0.3 \\
1.0 &.- & 0.3 \\
\hline 100.0 & & 100.0
\end{tabular}

Zone 3

$$
\begin{array}{r}
66.0 \\
9.4 \\
11.3 \\
3.8 \\
3.8 \\
1.9 \\
1.9 \\
1.9 \\
\hline 100.0
\end{array}
$$

25.0

16.7

20.7

16.7

8.3

4.2

4.2

$\frac{4.2}{100.0}$

36.8

15.8

15.8

10.5

5.3

10.5

$\frac{5.3}{100.0}$
36.7

28.3

16.7

8. 3

3.3

3. 3

1.7

$\frac{1.7}{100.0}$

58.7

27.3

3.3

4.1

3.3

2.5

$\frac{0.8}{100.0}$
52.9

17.5

2.9

16.5

3.7

4.6

1.2

$\frac{0.7}{100.0}$

47.3

23.7

11.3

6.4

4.5

2. 3

3.4

$\frac{1.1}{100.0}$

56.0

24.4

3.7

7.8

6.2

1.1

$\frac{0.8}{100.0}$
157.5

42.3

33.4

28.0

15.2

10.3

6.9

$\frac{6.4}{300.0}$

109.0

68.7

48.7

31.4

16.1

9.8

9.3

$\frac{7.0}{300.0}$

Herbs and Woody Seedlings

Leersia virginica

Planera aquatica

Brunnichia cirrhosa

Commelina virginica

Leersia sp.
10.4

14.8

10.4

4.4

6.0
19.0

8.4

7.2

11.3

7.8
151.5

67.5

22.8

22.4

14.8

14.1

$\frac{6.9}{300.0}$

29.4

23.2

17.6

15.7

13.8 
Table D-7--continued

\begin{tabular}{|c|c|c|c|c|}
\hline Species & $\begin{array}{l}\text { Percent } \\
\text { Relative } \\
\text { Frequency }\end{array}$ & $\begin{array}{r}\text { Percent } \\
\text { Relative } \\
\text { Density } \\
\end{array}$ & $\begin{array}{c}\text { Percent } \\
\text { Relative } \\
\text { Dominance }\end{array}$ & $\begin{array}{c}\text { Importance } \\
\text { Value }\end{array}$ \\
\hline Aster $\mathrm{sp}$ & 6.0 & -- & 6.9 & 12.9 \\
\hline Saururus cernuus & 4.4 & - & 8.5 & 12.9 \\
\hline Taxodium distichum & 5.1 & - & 3.6 & 8.7 \\
\hline Forestiera acuminata & 5.1 & - & 2.5 & 7.6 \\
\hline Onoclea sensibilis & 3.7 & -- & 3.2 & 6.9 \\
\hline Lindernia dubia & 3.7 & - & 2.1 & 5.8 \\
\hline Cocculus carolinus & 2.9 & - & 2.1 & 5.0 \\
\hline Justicia ovata & 2.2 & -- & 2.8 & 5.0 \\
\hline Echinodorus cordifolius & 2.2 & - & 2.8 & 5.0 \\
\hline Quercus lyrata & 2.9 & - & 0.8 & 3.7 \\
\hline Boehmeria cylindrica & 2.9 & - & 0.8 & 3.7 \\
\hline Cephalanthus occidentalis & 2.2 & - & 0.6 & 2.8 \\
\hline Carya aquatica & 2.2 & - & 0.6 & 2.8 \\
\hline Trachelospermum difforme & 0.7 & - & 1.3 & 2.0 \\
\hline Smilax rotundifolia & 0.7 & - & 1.3 & 2.0 \\
\hline Pluchea camphorata & 0.7 & -. & 1.3 & 2.0 \\
\hline Lysimachia radicans & 0.7 & - & 1.3 & 2.0 \\
\hline Hibiscus laevis & 0.7 & - & 1.3 & 2.0 \\
\hline Celtis laevigata & 0.7 & - & 1.3 & 2.0 \\
\hline Acer rubrum & 1.5 & - & 0.4 & 1.9 \\
\hline Spilanthes americana & 0.7 & - & 0.2 & 0.9 \\
\hline Toxicodendron radicans & 0.7 & -- & 0.2 & 0.9 \\
\hline Asclepias perennis & 0.7 & - & 0.2 & 0.9 \\
\hline \multirow[t]{3}{*}{ Ammannia coccinea } & 0.7 & - & 0.2 & 0.9 \\
\hline & $\overline{100.0}$ & & 100.0 & 200.0 \\
\hline & Zone 4 & & & \\
\hline \multicolumn{5}{|l|}{ Trees } \\
\hline Liquidambar styraciflua & 21.8 & 28.2 & 76.6 & 126.6 \\
\hline Celtis laevigata & 39.2 & 48.7 & 6.5 & 94.4 \\
\hline Fraxinus pennsylvanica & 13.0 & 7.7 & 10.6 & 31.3 \\
\hline Ulmus americana & 13.0 & 7.7 & 1.2 & 21.9 \\
\hline Acer negundo & 8.7 & 5.1 & 1.5 & 15.3 \\
\hline \multirow[t]{2}{*}{ Acer saccharinum } & 4.3 & 2.6 & 3.6 & 10.5 \\
\hline & $\overline{100.0}$ & 100.0 & 100.0 & 300.0 \\
\hline \multicolumn{5}{|l|}{ Saplings and Shrubs } \\
\hline Celtis laevigata & 52.5 & 82.0 & 86.0 & 220.5 \\
\hline Planera aquatica & 15.8 & 9.0 & 6.5 & 31.3 \\
\hline Ulmus americana & 15.8 & 4.5 & 4.5 & 24.8 \\
\hline Quercus Iyrata & 5.3 & 1.5 & 1.4 & 8.2 \\
\hline Fraxinus pennsylvanica & 5.3 & 1.5 & 0.8 & 7.6 \\
\hline \multirow[t]{2}{*}{ Forestiera acuminata } & 5.3 & 1.5 & 0.8 & 7.6 \\
\hline & $\overline{100.0}$ & 100.0 & $\overline{100.0}$ & 300.0 \\
\hline
\end{tabular}


Table D-7--continued

\begin{tabular}{|c|c|c|c|c|}
\hline Species & 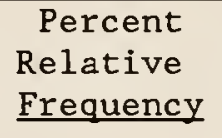 & $\begin{array}{r}\text { Percent } \\
\text { Relative } \\
\text { Density } \\
\end{array}$ & $\begin{array}{r}\text { Percent } \\
\text { Relative } \\
\text { Dominance }\end{array}$ & $\begin{array}{c}\text { Importance } \\
\text { Value }\end{array}$ \\
\hline \multicolumn{5}{|l|}{ Woody Vines } \\
\hline Toxicodendron radicans & 11.5 & 31.9 & 60.1 & 103.5 \\
\hline Smilax rotundifolia & 17.3 & 20.5 & 14.2 & 52.0 \\
\hline Cocculus carolinus & 19.3 & 19.0 & 11.1 & 49.4 \\
\hline Trachelospermum difforme & 17.3 & 11.1 & 4.3 & 32.7 \\
\hline Brunnichia cirrhosa & 15.5 & 8.7 & 4.1 & 28.3 \\
\hline Smilax hispida & 5.8 & 3.6 & 2.3 & 11.7 \\
\hline Campsis radicans & 3.8 & 2.0 & 1.3 & 7.1 \\
\hline Ampelopsis arborea & 3.8 & 1.6 & 1.6 & 7.0 \\
\hline Smilax bona-nox & 3.8 & 1.2 & 0.7 & 5.7 \\
\hline Wisteria frutescens & 1.9 & 0.4 & 0.3 & 2.6 \\
\hline & $\overline{100.0}$ & $\overline{100.0}$ & $\overline{100.0}$ & $\overline{300.0}$ \\
\hline \multicolumn{5}{|l|}{ Herbs and Woody Seedlings } \\
\hline Cocculus carolinus & 8.2 & - & 9.7 & 17.9 \\
\hline Leersia virginica & 7.7 & $\cdots$ & 11.5 & 19.2 \\
\hline Aster sp. & 5.4 & -- & 13.1 & 18.5 \\
\hline Commel ina virginica & 5.8 & -- & 13.8 & 19.6 \\
\hline Brunnichia cirrhosa & 5.4 & -- & 7.8 & 13.2 \\
\hline Boehmeria cylindrica & 6.7 & - & 6.2 & 12.9 \\
\hline Trachelospermum difforme & 6.7 & $\cdots$ & 5.3 & 12.0 \\
\hline Toxicodendron radicans & 5.4 & -- & 4.3 & 9.7 \\
\hline Campsis radicans & 3.4 & -- & 6.1 & 9.5 \\
\hline Leersia sp. & 4.8 & -- & 4.2 & 9.0 \\
\hline Smilax rotundifolia & 5.4 & -- & 3.1 & 8.5 \\
\hline Spermacoce glabra & 4.4 & -- & 1.7 & 6.1 \\
\hline Ampelopsis arborea & 2.9 & -- & 1.9 & 4.8 \\
\hline Vitis vulpina & 2.9 & - & 1.3 & 4.2 \\
\hline Planera aquatica & 2.0 & -- & 1.7 & 3.7 \\
\hline Acer rubrum & 2.9 & - & 0.7 & 3.6 \\
\hline Viola sp. & 2.0 & -- & 0.5 & 2.5 \\
\hline Smilax hispida & 1.5 & - & 1.0 & 2.5 \\
\hline Cardiospermum halicacabum & 1.5 & -- & 1.0 & 2.5 \\
\hline Smilax bona-nox & 1.5 & -- & 0.4 & 1.9 \\
\hline Onoclea sensibilis & 1.5 & - & 0 . & 1.9 \\
\hline Celtis laevigata & 1.5 & - & 0.4 & 1.9 \\
\hline Vitis riparia & 1.0 & $\cdots$ & 0.2 & 1.2 \\
\hline Polygonum hydropiperoides & 1.0 & -- & 0.2 & 1.2 \\
\hline Mikania scandens & 1.0 & -- & 0.2 & 1.2 \\
\hline Iva annua & 1.0 & -- & 0.2 & 1.2 \\
\hline Passiflora lutea & 0.5 & - & 0.7 & 1.2 \\
\hline Justicia ovata & 0.5 & -- & 0.7 & 1.2 \\
\hline Brunnichia cirrhosa & 0.5 & $-\cdot$ & 0.7 & 1.2 \\
\hline Ulmus americana & 0.5 & -- & 0.1 & 0.6 \\
\hline Taxodium distichum & 0.5 & -- & 0.1 & 0.6 \\
\hline Solanum carolinense & 1.5 & -- & 0.1 & 0.6 \\
\hline Smilax glauca & 0.5 & - & 0.1 & 0.6 \\
\hline
\end{tabular}


Table D-7--continued

\begin{tabular}{|c|c|c|c|c|}
\hline Species & $\begin{array}{l}\text { Percent } \\
\text { Relative } \\
\text { Frequency }\end{array}$ & $\begin{array}{r}\text { Percent } \\
\text { Relative } \\
\text { Density } \\
\end{array}$ & $\begin{array}{l}\text { Percent } \\
\text { Relative } \\
\text { Dominance }\end{array}$ & $\begin{array}{c}\text { Importance } \\
\text { Value }\end{array}$ \\
\hline Pluchea camphorata & 0.5 & -- & 0.1 & 0.6 \\
\hline Melothria pendula & 0.5 & - & 0.1 & 0.6 \\
\hline Matelea gonocarpa & 0.5 & -- & 0.1 & 0.6 \\
\hline Cephalanthus occidentalis & 0.5 & - & 0.1 & 0.6 \\
\hline Cayaponia quinqueloba & 0.5 & - & 0.1 & 0.6 \\
\hline Aristolochia serpentaria & 0.5 & -- & 0.1 & 0.6 \\
\hline & $\overline{100.0}$ & & $\overline{100.0}$ & $\overline{200.0}$ \\
\hline
\end{tabular}


Table D- 8

Importance Values for Species Occurring at Site 8 .

Arranged by Zone and Vegetation Layer

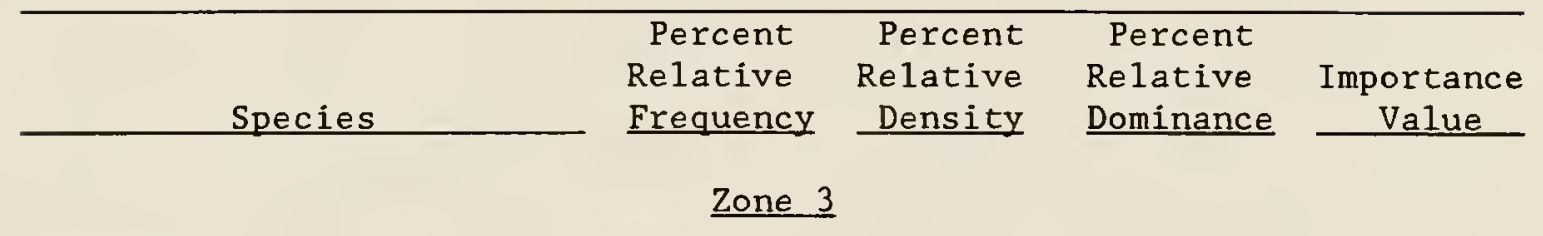

\section{Trees}

Planera aquatica

Quercus lyrata

Forestiera acuminata

Carya aquatica

Salix nigra

Taxodium distichum

Gleditsia aquatica

Fraxinus pennsylvanica

Acer saccharinum

Ulmus americana

Saplings and Shrubs

Planera aquatica

Forestiera acuminata

Fraxinus pennsylvanica

Woody Vines

Campsis radicans

Brunnichia cirrhosa

Herbs and Woody Seedlings

Forestiera acuminata

Cephalanthus occidentalis

Planera aquatica

Brunnichia cirrhosa

Vitis palmata

$\begin{array}{r}21.8 \\ 13.0 \\ 13.0 \\ 15.2 \\ 8.7 \\ 10.9 \\ 4.3 \\ 8.7 \\ 2.2 \\ 2.2 \\ \hline 100.0\end{array}$

$$
29.7
$$

16.7

19.0

9.5

4.8

7.1

4.8

4.8

2.4

$\frac{1.2}{100.0}$

52.9

35.3

11.8

100.0

50.0

$\frac{50.0}{100.0}$

$\begin{array}{r}50.0 \\ 50.0 \\ \hline 100.0\end{array}$

44.5

48.1

$\frac{7.4}{100.0}$

10.2

31.0

5.3

9.1

19.3

9.9

10.2

2. 1

2. 1

$\frac{0.8}{100.0}$

61.7

60.7

37.3

33.8

32.8

27.9

19.3

15.6

6.7

$\frac{4.2}{300.0}$

148.8

126.3

$\frac{24.9}{300.0}$

$\begin{array}{r}42.9 \\ 5.7 \\ \hline 100.0\end{array}$

69.2

169.2

30.8

130.8

300.0

$\begin{array}{rrrr}43.7 & - & 32.9 & 76.6 \\ 12.4 & -- & 34.0 & 46.4 \\ 18.8 & - & 14.2 & 33.0 \\ 18.8 & -- & 14.2 & 33.0 \\ 6.3 & -- & \frac{4.7}{200.0}\end{array}$

Zone 4

Trees

Quercus phellos

28.7

34.1

36.2

99.0

Quercus lyrata

Fraxinus pennsylvanica

17.8

14.9

28.1

60.8

17.8

21.3

10.8

49.9

Quercus nuttallii

10.6

6.0

27.3

10.7

6.4

20.1

Carya aquatica

7.1

8.5

3.0

19.5 
Table D-8--continued

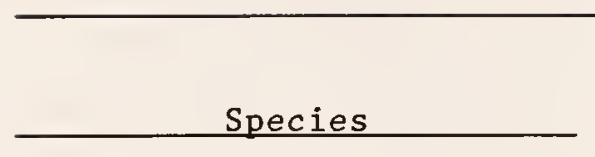

\begin{tabular}{crcrc}
$\begin{array}{c}\text { Percent } \\
\text { Relative } \\
\text { Frequency }\end{array}$ & $\begin{array}{c}\text { Percent } \\
\text { Relative } \\
\text { Density }\end{array}$ & $\begin{array}{c}\text { Percent } \\
\text { Relative } \\
\text { Dominance }\end{array}$ & $\begin{array}{c}\text { Importance } \\
\text { Value }\end{array}$ \\
\cline { 5 - 5 } 3.6 & & 2.1 & 11.7 & \\
$\frac{3.6}{100.0}$ & $\frac{2.1}{100.0}$ & $\frac{0.3}{100.0}$ & $\frac{6.0}{300.0}$
\end{tabular}

Quercus palustris

Diospyros virginiana

Saplings and Shrubs

Ulmus americana

Ilex decidua

Crataegus viridis

Fraxinus pennsylvanica

Diospyros virginiana

Quercus phellos

$\begin{array}{r}24.0 \\ 28.0 \\ 24.0 \\ 16.0 \\ 4.0 \\ 4.0 \\ \hline 100.0\end{array}$

35.8

35.8

41.5

101.3

32.2

96.0

14.3

54.7

5.6

27.6

5.0

13.5

6.0

$\frac{1 \cdot 4}{100 \cdot 0}$

$\frac{6.9}{300.0}$

Woody Vines

Campsis radicans

Berchemia scandens

$\begin{array}{r}41.7 \\ 25.0 \\ 16.7 \\ 8.3 \\ 8.3 \\ \hline 100.0\end{array}$

36.4

43.7

121.8

27.3

88.7

Vitis palmata

Vitis riparia

Cocculus carolinus

\begin{tabular}{rrrr}
16.4 & - & 37.5 & 53.9 \\
15.1 & -- & 16.3 & 31.4 \\
12.3 & - & 15.1 & 27.4 \\
11.0 & - & 4.9 & 15.9 \\
8.2 & - & 6.8 & 15.0 \\
4.1 & - & 5.0 & 9.1 \\
5.5 & - & 2.4 & 7.9 \\
4.1 & - & 1.8 & 5.9 \\
2.7 & - & 1.2 & 3.9 \\
2.7 & - & 1.2 & 3.9 \\
2.7 & - & 1.2 & 3.9 \\
2.7 & - & 1.2 & 3.9 \\
1.4 & - & 0.6 & 2.0 \\
1.4 & - & 0.6 & 2.0 \\
1.4 & -- & 0.6 & 2.0 \\
1.4 & - & 0.6 & 2.0 \\
1.4 & - & 0.6 & 2.0 \\
1.4 & -- & 0.6 & 2.0 \\
1.4 & - & 0.6 & 2.0 \\
2.7 & -- & 1.2 & 3.9 \\
\hline 100.0 & & 100.0 & 200.0
\end{tabular}

Herbs and Woody Seedlings

Campsis radicans
Trachelospermum difforme
Viola papilionacea
Planera aquatica
Leersia virginica
Cocculus carolinus
Carex squarrosa
Quercus phellos
Ilex decidua
Diospyros virginiana
Carya aquatica
Berchemia scandens
Vitis palmata
Taxodium distichum
Smilax glauca
Quercus lyrata
Dioscorea quaternata
Crataegus viridis
Clematis crispa
Brunnichia cirrhosa

14.5

44.8

31.1

0.8

$\frac{13.6}{300.0}$ 
Table D-9

Importance Values for Species Occurring at Site 9 , Arranged by Zone and Vegetation Layer

Species

\begin{tabular}{cccc} 
Percent & Percent & Percent & \\
Relative & Relative & Relative & Importance \\
Frequency & Density & Dominance & Value \\
\cline { 3 - 4 } & & &
\end{tabular}

Zone 3

\section{Trees}

Quercus lyrata

Fraxinus pennsylvanica

Carya aquatica

Ulmus americana

Quercus palustris

Taxodium distichum

Quercus phellos

Diospyros virginiana

Gleditsia aquatica

Saplings and Shrubs

Forestiera acuminata

Cephalanthus occidentalis

Woody Vines

None present

Herbs and Woody Seedlings

Leersia sp.
Forestiera acuminata
Leersia virginica
Vitis palmata
Planera aquatica
Asclepias perennis
Ageratina altissima
Clematis crispa
Acalypha rhomboidea
Quercus lyrata
Carya aquatica
Brunnichia cirrhosa
Ulmus americana
Parthenocissus quinquefolia
Lysimachia radicans
Ampelopsis arborea

\begin{tabular}{rrrr}
23.5 & -- & 65.1 & 88.6 \\
20.7 & -- & 6.5 & 27.2 \\
5.6 & -- & 10.2 & 15.8 \\
9.7 & -- & 5.3 & 15.0 \\
9.7 & -- & 3.0 & 12.7 \\
5.6 & -- & 1.7 & 7.3 \\
4.2 & -- & 1.3 & 5.5 \\
4.2 & -- & 1.3 & 5.5 \\
2.8 & -- & 1.3 & 4.1 \\
2.8 & -- & 0.9 & 3.7 \\
2.8 & -- & 0.9 & 3.7 \\
2.8 & -- & 0.9 & 3.7 \\
1.4 & -- & 0.4 & 1.8 \\
1.4 & -- & 0.4 & 1.8 \\
1.4 & -- & 0.4 & 1.8 \\
1.4 & -- & 0.4 & 1.8 \\
\hline 100.0 & & 100.0 & 200.0
\end{tabular}

$$
\begin{array}{r}
28.5 \\
14.3 \\
17.8 \\
17.8 \\
7.2 \\
3.6 \\
3.6 \\
3.6 \\
3.6 \\
\hline 100.0
\end{array}
$$

94.5

59.2

40.5

40.1

25.8

11.1

10.8

9.9

$\frac{8.1}{300.0}$

50.0

50.0

70.0

170.0

$\frac{50.0}{100.0}$

$\frac{50.0}{100.0}$

$\frac{30.0}{100.0}$

$\underline{130.0}$

300.0 
Table D-9--continued

\begin{tabular}{|c|c|c|c|c|}
\hline Species & $\begin{array}{c}\text { Percent } \\
\text { Relative } \\
\text { Frequency }\end{array}$ & $\begin{array}{r}\text { Percent } \\
\text { Relative } \\
\text { Density } \\
\end{array}$ & $\begin{array}{l}\text { Percent } \\
\text { Relative } \\
\text { Dominance }\end{array}$ & $\begin{array}{c}\text { Importance } \\
\text { Value }\end{array}$ \\
\hline \multicolumn{5}{|c|}{ Zone 6} \\
\hline \multicolumn{5}{|l|}{ Trees } \\
\hline Carya tomentosa & 38.4 & 45.5 & 36.3 & 120.2 \\
\hline Liquidambar styraciflua & 30.7 & 40.0 & 34.9 & 105.6 \\
\hline Quercus nigra & 15.4 & 7.3 & 15.0 & 37.7 \\
\hline Quercus alba & 7.7 & 3.6 & 5.0 & 16.3 \\
\hline Quercus velutina & 3.9 & 1.8 & 6.8 & 12.5 \\
\hline \multirow[t]{2}{*}{ Fraxinus americana } & 3.9 & 1.8 & 2.0 & 7.7 \\
\hline & 100.0 & 100.0 & 100.0 & $\overline{300.0}$ \\
\hline \multicolumn{5}{|l|}{ Saplings and Shrubs } \\
\hline Carya tomentosa & 22.3 & 38.2 & 42.2 & 102.7 \\
\hline Aralia spinosa & 11.1 & 22.5 & 17.9 & 512.5 \\
\hline Cercis canadensis & 15.7 & 10.3 & 9.7 & 35.7 \\
\hline Morus rubra & 11.1 & 7.8 & 9.0 & 27.9 \\
\hline Cornus florida & 9.0 & 4.4 & 4.8 & 18.2 \\
\hline Liquidambar styraciflua & 4.4 & 3.5 & 4.6 & 12.5 \\
\hline Ulmus alata & 4.4 & 3.5 & 3.2 & 11.1 \\
\hline Sassafras albidum & 4.4 & 2.6 & 2.6 & 9.6 \\
\hline Quercus 1yrata & 2.2 & 0.9 & 1.1 & 4.2 \\
\hline Ulmus rubra & 2.2 & 0.9 & 0.7 & 3.8 \\
\hline Rhus glabra & 2.2 & 0.9 & 0.7 & 3.8 \\
\hline Quercus velutina & 2.2 & 0.9 & 0.7 & 3.8 \\
\hline Prunus serotina & 2.2 & 0.9 & 0.7 & 3.8 \\
\hline Nyssa sylvatica & 2.2 & 0.9 & 0.7 & 3.8 \\
\hline Callicarpa americana & 2.2 & 0.9 & 0.7 & 3.8 \\
\hline \multirow[t]{2}{*}{ Acer rubrum } & 2.2 & 0.9 & 0.7 & 3.8 \\
\hline & 100.0 & 100.0 & 100.0 & 300.0 \\
\hline \multicolumn{5}{|l|}{ Woody Vines } \\
\hline Parthenocissus quinquefolia & 37.5 & 64.0 & 73.3 & 174.8 \\
\hline Toxicodendron radicans & 33.3 & 29.0 & 19.5 & 81.8 \\
\hline Vitis aestivalis & 12.5 & 3.0 & 4.4 & 19.9 \\
\hline Smilax glauca & 8.3 & 2.0 & 1.4 & 11.7 \\
\hline Smilax rotundifolia & 4.2 & 1.0 & 0.7 & 5.9 \\
\hline \multirow[t]{2}{*}{ Bignonia capreolata } & 4.2 & 1.0 & 0.7 & 5.9 \\
\hline & 100.0 & $\overline{100.0}$ & $\overline{100.0}$ & $\overline{300.0}$ \\
\hline \multicolumn{5}{|l|}{ Herbs and Woody Seedlings } \\
\hline Toxicodendron radicans & 4.8 & -- & 16.1 & 20.9 \\
\hline Carya tomentosa & 5.2 & -- & 12.7 & 17.9 \\
\hline Dioclea multiflora & 6.0 & $\cdots$ & 10.1 & 16.1 \\
\hline Chasmanthium sessiliflorum & 5.2 & - & 7.9 & 13.1 \\
\hline Parthenocissus quinquefolia & 6.0 & - & 5.3 & 11.3 \\
\hline Cercis canadensis & 3.7 & - & 6.8 & 10.5 \\
\hline Dichanthelium commutatum & 5.6 & -- & 3.3 & 8.9 \\
\hline
\end{tabular}


Table D-9.-continued

\begin{tabular}{|c|c|c|c|c|}
\hline Species & \begin{tabular}{c}
\multicolumn{1}{c}{ Percent } \\
Relative \\
Frequency
\end{tabular} & $\begin{array}{r}\text { Percent } \\
\text { Relative } \\
\text { Density } \\
\end{array}$ & $\begin{array}{r}\begin{array}{r}\text { Percent } \\
\text { Relative } \\
\text { Dominance }\end{array} \\
\end{array}$ & $\begin{array}{c}\text { Importance } \\
\text { Value }\end{array}$ \\
\hline Aralia spinosa & 1.9 & -- & 6.1 & 8.0 \\
\hline Sabatia calycina & 3.7 & -- & 2.0 & 5.7 \\
\hline Galium circaezans & 3.3 & - & 1.9 & 5.2 \\
\hline Vitis rotundifolia & 3.1 & -- & 1.6 & 4.7 \\
\hline Carex flaccidula & 3.0 & $\cdots$ & 1.0 & 4.0 \\
\hline Ampelopsis brevipedunculata & 1.9 & -- & 2.0 & 3.9 \\
\hline Morus rubra & 1.1 & -- & 2.2 & 3.3 \\
\hline Desmodium glabellum & 1.9 & - & 1.3 & 3.2 \\
\hline Ageratina altissima & 2.3 & - & 0.7 & 3.0 \\
\hline Chasmanthium laxum & 0.8 & - & 2.1 & 2.9 \\
\hline Vitis aestivalis & 1.5 & -- & 1.1 & 2.6 \\
\hline Lactuca floridana & 1.9 & - & 1.3 & 3.2 \\
\hline Ulmus rubra & 1.9 & - & 0.6 & 2.5 \\
\hline Rubrus argutus & 1.1 & - & 1.0 & 2.1 \\
\hline Quercus phellos & 1.5 & - & 0.5 & 2.0 \\
\hline Desmodium passiflorum & 1.5 & -- & 0.5 & 2.0 \\
\hline Carex cephalophora & 1.5 & -- & 2.1 & 2.9 \\
\hline Sambucus canadensis & 0.8 & -- & 0.9 & 1.7 \\
\hline Elytraria carolinensis & 0.8 & - & 0.9 & 1.7 \\
\hline Campsis radicans & 0.8 & - & 0.9 & 1.7 \\
\hline Rubus occidentalis & 1.1 & - & 0.4 & 1.5 \\
\hline Ilex decidua & 1.1 & - & 0.4 & 1.5 \\
\hline Crataegus sp. & 1.1 & -- & 0.4 & 1.5 \\
\hline Acer rubrum & 1.1 & - & 0.4 & 1.5 \\
\hline Smilax bona-nox & 0.4 & -- & 0.8 & 1.2 \\
\hline Quercus stellata & 0.4 & - & 0.8 & 1.2 \\
\hline Vernonia gigantea & 0.8 & - & 0.2 & 1.0 \\
\hline Smilax glauca & 0.8 & $\cdots$ & 0.2 & 1.0 \\
\hline Rubus sp. & 0.8 & $\cdots$ & 0.2 & 1.0 \\
\hline Quercus alba & 0.8 & - & 0.2 & 1.0 \\
\hline Prunus serotina & 0.8 & $\cdots$ & 0.2 & 1.0 \\
\hline Unknown & 0.8 & -- & 0.2 & 1.0 \\
\hline Oxalis debilis & 0.8 & - & 0.2 & 1.0 \\
\hline Unknown & 0.8 & -- & 0.2 & 1.0 \\
\hline Galium sp. & 0.8 & - & 0.2 & 1.0 \\
\hline Unknown & 0.8 & - & 0.2 & 1.0 \\
\hline Cornus florida & 0.8 & -- & 0.2 & 1.0 \\
\hline Bignonia capreolata & 0.8 & - & 0.2 & 1.0 \\
\hline Viola triloba & 0.4 & - & 0.1 & 0.5 \\
\hline Viola papilionacea & 0.4 & -- & 0.1 & 0.5 \\
\hline Vitis palmata & 0.4 & - & 0.1 & 0.5 \\
\hline Ulmus americana & 0.4 & -- & 0.1 & 0.5 \\
\hline Trachelospermum difforme & 0.4 & - & 0.1 & 0.5 \\
\hline Trepocarpus aethusae & 0.4 & - & 0.1 & 0.5 \\
\hline Smilax rotundifolia & 0.4 & $\cdots$ & 0.1 & 0.5 \\
\hline Unknown & 0.4 & - & 0.1 & 0.5 \\
\hline Sassafras albidum & 0.4 & - & 0.1 & 0.5 \\
\hline
\end{tabular}


Table D-9--continued

\begin{tabular}{|c|c|c|c|c|}
\hline Species & 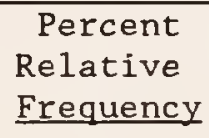 & $\begin{array}{r}\text { Percent } \\
\text { Relative } \\
\text { Density } \\
\end{array}$ & $\begin{array}{c}\text { Percent } \\
\text { Relative } \\
\text { Dominance }\end{array}$ & $\begin{array}{c}\text { Importance } \\
\text { Value }\end{array}$ \\
\hline Rubus sp. & 0.4 & $\cdots$ & 0.1 & 0.5 \\
\hline Quercus nigra & 0.4 & - & 0.1 & 0.5 \\
\hline Polygonum scandens & 0.4 & - & 0.1 & 0.5 \\
\hline Paspalum sp. & 0.4 & $\cdots$ & 0.1 & 0.5 \\
\hline Oxalis debilis & 0.4 & - & 0.1 & 0.5 \\
\hline Leersia virginica & 0.4 & -- & 0.1 & 0.5 \\
\hline Leersia sp. & 0.4 & $\cdots$ & 0.1 & 0.5 \\
\hline Juniperus virginiana & 0.4 & $\ldots$ & 0.1 & 0.5 \\
\hline Galium uniflorum & 0.4 & -- & 0.1 & 0.5 \\
\hline Galium trifidum & 0.4 & - & 0.1 & 0.5 \\
\hline Unknown & 0.4 & -- & 0.1 & 0.5 \\
\hline Galium circaezans & 0.4 & - & 0.1 & 0.5 \\
\hline Eupatorium sp. & 0.4 & - & 0.1 & 0.5 \\
\hline Elytraria carolinensis & 0.4 & - & 0.1 & 0.5 \\
\hline Dioscorea quaternata & 0.4 & $\cdots$ & 0.1 & 0.5 \\
\hline Desmodium sp. & 0.4 & -- & 0.1 & 0.5 \\
\hline Desmodium paniculatum & 01.4 & - & 0.1 & 0.5 \\
\hline Celtis laevigata & 0.4 & - & 0.1 & 0.5 \\
\hline Unknown & 0.4 & -- & 0.1 & 0.5 \\
\hline Callicarpa americana & 0.4 & - & 0.1 & 0.5 \\
\hline Carex albolutescens & 0.4 & $\cdots$ & 0.1 & 0.5 \\
\hline \multirow[t]{2}{*}{ Agrimonia pubescens } & 0.4 & - & 0.1 & 0.5 \\
\hline & $\overline{100.0}$ & & $\overline{100.0}$ & $\overline{200.0}$ \\
\hline
\end{tabular}


Table D-10

Importance Values for Species Occurring at Site 10 , Arranged by Zone and Vegetation Layer

Species

\begin{tabular}{rrrr} 
Percent & Percent & Percent & \\
Relative & Relative & Relative & Importance \\
Frequency & Density & Dominance & Value \\
\cline { 3 - 4 } & &
\end{tabular}

Zone 2

\section{Trees}

Taxodium distichum

Ilex decidua

Nyssa aquatica

Nyssa biflora

Acer drummondii

Quercus 1yrata

Acer rubrum

Liquidambar styraciflua

Carpinus caroliniana

Saplings and Shrubs

Styrax americana

Ilex decidua

Ilex amelanchier

Itea virginica

Acer drummondii

Quercus lyrata

Cephalanthus occidentalis

Taxodium distichum

Carpinus caroliniana

Woody Vines

Vitis rotundifolia

Ampelopsis arborea

Campsis radicans

Herbs and Woody Seedlings

Styrax americana

Ampelopsis arborea

Quercus lyrata

Planera aquatica

Cephalanthus occidentalis

Viburnum dentatum

Taxodium distichum

Nyssa biflora

Nyssa aquatica

\section{4 \\ 13.3 \\ 13.3 \\ 13.3 \\ 10.1 \\ 6.7 \\ 3. 3 \\ 3.3 \\ $\frac{3.3}{100.0}$}

$$
\begin{array}{r}
25.6 \\
23.0 \\
10.3 \\
12.8 \\
12.8 \\
7.7 \\
2.6 \\
2.6 \\
2.6 \\
\hline 100.0
\end{array}
$$

62.5

25.0

12.5

100.0

28.5

10.6

7.1

7.1

7.1

3.6

3.6

3.6

3.6
40.2

28.3

6.0

9.0

4.5

3.0

6.0

1.5

$\frac{1.5}{100.0}$

32.8

26.7

20.0

10.3

4.2

3.0

1.8

0.6

$\frac{0.6}{100.0}$

100.0

50.0

40.0

10.0

100.0
59.7

3.0

14.6

10.5

1.6

4.9

4.7

0.9

$\frac{0.1}{100.0}$

31.6

31.8

16.9

7.6

4.3

4.3

2.1

0.7

$\frac{0.7}{100.0}$

$\begin{array}{r}50.0 \\ 38.2 \\ 11.8 \\ \hline 100.0\end{array}$

162.5

103.2

$\frac{34.3}{300.0}$
133.3

44.6

33.9

32.8

16.2

14.6

14.0

5.7

$\frac{4.9}{300.0}$

$$
90.0
$$

81.5

47.2

30.7

21.3

15.0

6.5

3.9

$\frac{3.9}{300.0}$

42.1

70.6

18.8

29.4

4.6

11.7

4.6

11.7

2.3

5.9

2. 3

5.9

2.3

5.9

2. 3

5.9

2.3

5.9 
Table D-10--continued

\begin{tabular}{|c|c|c|c|c|}
\hline Species & $\begin{array}{c}\text { Percent } \\
\text { Relative } \\
\text { Frequency }\end{array}$ & $\begin{array}{r}\text { Percent } \\
\text { Relative } \\
\text { Density } \\
\end{array}$ & $\begin{array}{r}\text { Percent } \\
\text { Relative } \\
\text { Dominance } \\
\end{array}$ & $\begin{array}{c}\text { Importance } \\
\text { Value }\end{array}$ \\
\hline Ilex decidua & 3.6 & -- & 2.3 & 5.9 \\
\hline Forestiera acuminata & 3.6 & - - & 2.3 & 5.9 \\
\hline Ageratina altissima & 3.6 & -- & 2.3 & 5.9 \\
\hline Campsis radicans & 3.6 & -- & 2.3 & 5.9 \\
\hline Carpinus caroliniana & 3.6 & -- & 2.3 & 5.9 \\
\hline Brunnichia cirrhosa & 3.6 & -- & 2.3 & 5.9 \\
\hline \multirow[t]{3}{*}{ Acer rubrum } & 3.6 & & 2.3 & 5.9 \\
\hline & 100.0 & & 100.0 & 200.0 \\
\hline & Zone 3 & & & \\
\hline \multicolumn{5}{|l|}{ Trees } \\
\hline Nyssa biflora & 41.6 & 61.0 & 48.8 & 151.4 \\
\hline Acer drummondii & 33.3 & 20.8 & 35.8 & 89.9 \\
\hline Liquidambar styraciflua & 4.2 & 3.9 & 9.4 & 17.5 \\
\hline Diospyros virginiana & 4.2 & 6.5 & 3.6 & 14.3 \\
\hline Carpinus caroliniana & 8.3 & 3.9 & 1.5 & 13.7 \\
\hline Crataegus aestivalis & 4.2 & 2.6 & 0.3 & 7.1 \\
\hline \multirow[t]{2}{*}{ Quercus nigra } & 4.2 & 1.3 & 0.6 & 6.1 \\
\hline & $\overline{100.0}$ & $\overline{100.0}$ & $\overline{100.0}$ & $\overline{300.0}$ \\
\hline \multicolumn{5}{|l|}{ Saplings and Shrubs } \\
\hline Styrax americana & 18.5 & 38.7 & 38.8 & 96.0 \\
\hline Nyssa biflora & 16.3 & 14.1 & 20.2 & 50.6 \\
\hline Acer drummondi i & 16.3 & 17.6 & 16.5 & 50.4 \\
\hline Arundinaria gigantea & 9.2 & 4.4 & 3.0 & 16.6 \\
\hline Itea virginica & 2.3 & 7.1 & 3.8 & 13.2 \\
\hline Carpinus caroliniana & 7.0 & 2.6 & 3.0 & 12.6 \\
\hline Ilex decidua & 4.7 & 3.5 & 3.8 & 12.0 \\
\hline Liquidambar styraciflua & 4.7 & 2.6 & 2.4 & 9.7 \\
\hline Taxodium distichum & 4.7 & 1.7 & 1.6 & 8.0 \\
\hline Fraxinus pennsylvanica & 4.7 & 1.7 & 0.9 & 7.3 \\
\hline Diospyros virginiana & 4.7 & 1.7 & 0.9 & 7.3 \\
\hline Cephalanthus occidentalis & 2.3 & 1.7 & 2.3 & 6.3 \\
\hline Quercus laurifolia & 2.3 & 1.7 & 1.7 & 5.7 \\
\hline \multirow[t]{2}{*}{ U1mus americana } & 2.3 & 0.9 & 1.1 & 4.3 \\
\hline & 100.0 & 100.0 & $\overline{100.0}$ & $\overline{300.0}$ \\
\hline \multicolumn{5}{|l|}{ Woody Vines } \\
\hline Vitis rotundifolia & 27.5 & 33.3 & 43.2 & 104.0 \\
\hline Toxicodendron radicans & 17.2 & 34.9 & 30.5 & 82.6 \\
\hline Berchemia scandens & 13.8 & 10.1 & 11.1 & 35.0 \\
\hline Ampelopsis arborea & 13.8 & 8.7 & 6.3 & 28.8 \\
\hline Brunnichia cirrhosa & 10.4 & 5.8 & 3.1 & 19.3 \\
\hline Bignonia capreolata & 6.9 & 2.9 & 3.2 & 13.0 \\
\hline
\end{tabular}


Table D-10--continued

\begin{tabular}{|c|c|c|c|c|}
\hline Species & 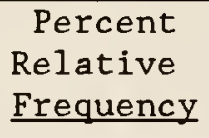 & $\begin{array}{r}\text { Percent } \\
\text { Relative } \\
\text { Density } \\
\end{array}$ & $\begin{array}{r}\text { Percent } \\
\text { Relative } \\
\text { Dominance }\end{array}$ & $\begin{array}{c}\text { Importance } \\
\text { Value } \\
\end{array}$ \\
\hline $\begin{array}{l}\text { Smilax rotundifolia } \\
\text { Campsis radicans }\end{array}$ & $\begin{array}{l}6.9 \\
3.5 \\
\end{array}$ & $\begin{array}{l}2.9 \\
1.4 \\
\end{array}$ & $\begin{array}{l}0.5 \\
2.1 \\
\end{array}$ & $\begin{array}{r}10.3 \\
7.0 \\
\end{array}$ \\
\hline \multicolumn{5}{|l|}{ Herbs and Woody Seedlings } \\
\hline Nyssa biflora & 15.3 & -- & 16.1 & 31.4 \\
\hline Berchemia scandens & 12.8 & $\cdots$ & 14.5 & 27.3 \\
\hline Saururus cernuus & 10.2 & -- & 13.2 & 23.4 \\
\hline Styrax americana & 12.8 & -- & 7.1 & 19.9 \\
\hline Ampelopsis arborea & 7.7 & -- & 11.7 & 19.4 \\
\hline Toxicodendron radicans & 5.1 & -- & 10.3 & 15.4 \\
\hline Itea virginica & 5.1 & - & 10.3 & 15.4 \\
\hline Lysimachia radicans & 5.1 & - & 2.8 & 7.9 \\
\hline Bignonia capreolata & 5.1 & $\cdots$ & 2.8 & 7.9 \\
\hline Ilex decidua & 2.6 & -- & 1.4 & 4.0 \\
\hline Campsis radicans & 2.6 & - & 1.4 & 4.0 \\
\hline Carya aquatica & 2.6 & -- & 1.4 & 4.0 \\
\hline Brunnichia cirrhosa & 2.6 & -- & 1.4 & 4.0 \\
\hline Boehmeria cylindrica & 2.6 & - & 1.4 & 4.0 \\
\hline Aristolochia serpentaria & 2.6 & -- & 1.4 & 4.0 \\
\hline Arundinaria gigantea & 2.6 & - & 1.4 & 4.0 \\
\hline \multirow[t]{2}{*}{ Acer rubrum } & 2.6 & -- & 1.4 & 4.0 \\
\hline & 100.0 & & 100.0 & 200.0 \\
\hline
\end{tabular}

Zone 4

\section{Trees}

Carpinus caroliniana

Quercus laurifolia

Quercus nigra

Acer rubrum

Nyssa sylvatica

Liquidambar styraciflua

Ulmus americana

Ilex decidua

Fraxinus pennsylvanica

$$
\begin{array}{r}
25.1 \\
15.6 \\
12.5 \\
15.6 \\
12.5 \\
9.4 \\
3.1 \\
3.1 \\
3.1 \\
\hline 100.0
\end{array}
$$

36.5

11.6

11.6

17.3

7.7

9.6

1.9

1.9

$\frac{1.9}{100.0}$

Saplings and Shrubs

Carpinus caroliniana

Liquidambar styraciflua

Acer rubrum

Quercus laurifolia

Quercus nigra

Cornus foemina

Nyssa sylvatica

Viburnum dentatum
14.0

1.0

12.4

9.4

6.3

9.4

9.4

1.6
23.9

22.4

22.1

8.6

5.6

4.1

3.7

2. 6
12.6

28.0

28.8

15.5

7.1

7.0

0.4

0.4

$\frac{0.2}{100.0}$

28.7

21.6

20.7

7.8

6.4

3.9

3.0

2.0
74.2

55.2

52.9

48.4

27.3

26.0

5.4

5.4

$\frac{5.2}{300.0}$ 
Table D-10--continued

\begin{tabular}{|c|c|c|c|c|}
\hline Species & $\begin{array}{c}\text { Percent } \\
\text { Relative } \\
\text { Frequency }\end{array}$ & $\begin{array}{r}\text { Percent } \\
\text { Relative } \\
\text { Density } \\
\end{array}$ & 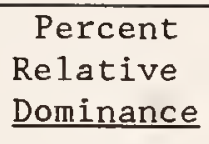 & $\begin{array}{c}\text { Importance } \\
\text { value } \\
\end{array}$ \\
\hline Diospyros virginiana & 3.1 & 1.5 & 1.0 & 5.6 \\
\hline Fraxinus pennsylvanica & 3.1 & 0.8 & 1.5 & 5.4 \\
\hline Ulmus americana & 3.1 & 0.8 & 0.7 & 4.6 \\
\hline Ilex amelanchier & 3.1 & 0.8 & 0.7 & 4.6 \\
\hline Ilex opaca & 3.1 & 0.8 & 0.6 & 4.5 \\
\hline Magnolia grandiflora & 1.6 & 0.4 & 0.3 & 2.3 \\
\hline Crataegus marshallii & 1.6 & 0.4 & 0.3 & 2.3 \\
\hline \multirow[t]{2}{*}{ Cephalanthus occidentalis } & 1.6 & 0.4 & 0.2 & 2.2 \\
\hline & 100.0 & 100.0 & $\overline{100.0}$ & $\overline{300.0}$ \\
\hline \multicolumn{5}{|l|}{ Woody Vines } \\
\hline Berchemia scandens & 34.4 & 24.7 & 41.0 & 100.1 \\
\hline Toxicodendron radicans & 10.3 & 29.0 & 13.5 & 52.8 \\
\hline Vitis rotundifolia & 17.3 & 13.0 & 16.3 & 46.6 \\
\hline Ampelopsis arborea & 10.4 & 13.0 & 21.2 & 44.6 \\
\hline Campsis radicans & 10.4 & 10.1 & 4.7 & 25.2 \\
\hline Smilax rotundifolia & 10.4 & 7.2 & 2.7 & 20.3 \\
\hline Brunnichia cirrhosa & 3.4 & 1.5 & 0.3 & 5.2 \\
\hline \multirow[t]{2}{*}{ Bignonia carpreolata } & 3.4 & 1.5 & 0.3 & 5.2 \\
\hline & 100.0 & 100.0 & 100.0 & 300.0 \\
\hline \multicolumn{5}{|l|}{ Herbs and Woody Seedlings } \\
\hline Quercus laurifolia & 11.9 & - & 17.5 & 29.4 \\
\hline Itea virginica & 6.7 & -. & 17.5 & 24.2 \\
\hline Mitchella repens & 5.0 & -- & 15.1 & 20.1 \\
\hline Acer rubrum & 10.2 & - & 9.2 & 19.4 \\
\hline Lysimachia radicans & 7.7 & -- & 6.1 & 13.8 \\
\hline Toxicodendron radicans & 5.9 & -- & 4.9 & 10.8 \\
\hline Smilax rotundifolia & 6.7 & -- & 3.2 & 9.9 \\
\hline Carex sp. & 6.7 & -- & 3.2 & 9.9 \\
\hline Chasmanthium sessiliflorum & 1.7 & -- & 6.6 & 8.3 \\
\hline Saururus cernuus & 3.4 & - & 3.7 & 7.1 \\
\hline Ampelopsis arborea & 3.4 & - & 3.7 & 7.1 \\
\hline Campsis radicans & 4.2 & -- & 2.0 & 6.2 \\
\hline Bignonia capreolata & 3.4 & -- & 1.6 & 5.0 \\
\hline Berchemia scandens & 3.4 & -- & 1.6 & 5.0 \\
\hline Quercus phe1los & 2.5 & - & 1.2 & 3.7 \\
\hline Brunnichia cirrhosa & 2.5 & -- & 1.2 & 3.7 \\
\hline Liquidambar styraciflua & 0.8 & -- & 2.5 & 3.3 \\
\hline Ascyrum hypericoides & 0.8 & -- & 2.5 & 3.3 \\
\hline Rubus trivialis & 1.7 & -- & 0.8 & 2.5 \\
\hline Nyssa sylvatica & 1.7 & -- & 0.8 & 2.5 \\
\hline Justicia ovata & 1.7 & -- & 0.8 & 2.5 \\
\hline Vitis rotundifolia & 0.8 & -- & 0.4 & 1.2 \\
\hline Quercus nigra & 0.8 & - & 0.4 & 1.2 \\
\hline Dichanthelium commutatum & 0.8 & -- & 0.4 & 1.2 \\
\hline Ilex decidua & 0.8 & - & 0.4 & 1.2 \\
\hline
\end{tabular}


Table D-10--continued

Species

Ageratina altissima

Diospyros virginiana

Cornus foemina

Clematis crispa

Carpinus caroliniana

Arundinaria gigantea
Percent Percent

Relative Relative

Frequency Density

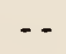

$-\cdot$

$--$

$--$

$--$

$-\cdot$
Percent

Relative

Dominance

0.4

0.4

0.4

0.4

0.4

$\frac{0.4}{100.0}$
Importance

Value

1.2

1.2

1.2

1.2

1.2

$\frac{1.2}{200.0}$

\section{Zone 6}

\section{Trees}

Liquidambar styraciflua

Carpinus caroliniana

29.5

35.5

21.6

16.9

Ilex opaca

20.7

16.9

14.7

Quercus nigra

Acer rubrum

Nyssa sylvatica

Ilex decidua

Diospyros virginiana

5.9

2.9

3.1

1.5

2.9

2.9

1.5

1.5

$\frac{2.9}{100.0}$

$\frac{1.5}{100.0}$

$$
\begin{array}{r}
72.9 \\
3.0 \\
6.4 \\
2.4 \\
10.3 \\
3.5 \\
1.1 \\
0.2 \\
0.2 \\
\hline 100.0
\end{array}
$$

137.9

45.3

40.9

34.0

19.3

7.9

5.5

4.6

4.6

Saplings and Shrubs

Carpinus caroliniana

Halesia diptera

14.7

26.9

28.6

70.2

14.7

25.9

27.7

68.3

13.2

15.9

15.1

44.2

14.7

8.5

7.5

30.7

5.9

6.5

6.3

18.7

10.3

2.8

3. 3

16.4

7.3

4.3

3.4

15.0

4.4

5.4

4.7

14.5

5.9

1.7

1.6

9.2

0.6

0.6

4.1

1.5

0.6

0.4

2.5

0.3

0.4

2.2

1.5

0.3

0.2

2.0

Magnolia grandiflora

$\frac{1.5}{100.0}$

$\frac{0.3}{100.0}$

$\frac{0.2}{100.0}$

$\frac{2.0}{300.0}$

\section{Woody Vines}

Toxicodendron radicans

$V$ itis rotundifolia

28.1

49.5

50.0

127.6

21.9

28.9

33.7

84.5

12.5

3.3

3.3

19.1

5.0

4.4

18.8

6.2

5.0

6.3

17.5

9.4

3.3

1.1

13.8

9.4

3.3

0.7

13.4 
Table D-10--continued

\begin{tabular}{|c|c|c|c|c|}
\hline Species & $\begin{array}{l}\text { Percent } \\
\text { Relative } \\
\text { Frequency }\end{array}$ & $\begin{array}{r}\text { Percent } \\
\text { Relative } \\
\text { Density } \\
\end{array}$ & $\begin{array}{l}\text { Percent } \\
\text { Relative } \\
\text { Dominance }\end{array}$ & $\begin{array}{c}\text { Importance } \\
\text { Value }\end{array}$ \\
\hline Trachelospermum difforme & $\frac{3.1}{100.0}$ & $\frac{1.7}{100.0}$ & $\frac{0.5}{100.0}$ & $\frac{5.3}{300.0}$ \\
\hline \multicolumn{5}{|l|}{ Herbs and Woody Seedlings } \\
\hline Toxicodendron radicans & 19.2 & - & 25.0 & 44.2 \\
\hline Halesia diptera & 16.2 & - & 19.7 & 35.9 \\
\hline Viburnum dentatum & 5.9 & - & 6.8 & 12.7 \\
\hline Carpinus caroliniana & 5.9 & -- & 6.8 & 12.7 \\
\hline Berchemia scandens & 2.9 & - & 9.1 & 12.0 \\
\hline Ilex decidua & 4.4 & - & 6.0 & 10.4 \\
\hline Carex blanda & 5.9 & - & 3.0 & 8.9 \\
\hline Ilex opaca & 2.9 & - & 5.3 & 8.2 \\
\hline Quercus nigra & 4.4 & - & 2.2 & 6.6 \\
\hline Campsis radicans & 4.4 & - & 2.2 & 6.6 \\
\hline Bignonia capreolata & 4.4 & - & 2.2 & 6.6 \\
\hline Vitis rotundifolia & 2.9 & - & 1.5 & 4.4 \\
\hline Poncirus trifoliata & 2.9 & - & 1.5 & 4.4 \\
\hline Crataegus marshallii & 2.9 & - & 1.5 & 4.4 \\
\hline Carya glabra & 2.9 & - & 1.5 & 4.4 \\
\hline Botrychium biternatum & 2.9 & - & 1.5 & 4.4 \\
\hline Viola papilionacea & 1.5 & - & 0.7 & 2.2 \\
\hline Smilax bona-nox & 1.5 & - & 0.7 & 2.2 \\
\hline Morus rubra & 1.5 & - & 0.7 & 2.2 \\
\hline Lespedeza sp. & 1.5 & - & 0.7 & 2.2 \\
\hline Carex sp. & 1.5 & - & 0.7 & 2.2 \\
\hline \multirow[t]{2}{*}{ Ampelopsis arborea } & 1.5 & - & 0.7 & 2.2 \\
\hline & 100.0 & & 100.0 & 200.0 \\
\hline
\end{tabular}


Table D-11

Importance Values for Species Occurring at Site 11.

Arranged by Zone and Vegetation Layer

Species

\begin{tabular}{lc}
\multicolumn{1}{c}{ Percent } & Percent \\
Relative & Relative \\
Frequency & Density
\end{tabular}

Percent

Relative

Dominance

Importance

Zone 2

\section{Trees}

Nyssa ogeche

Nyssa aquatica

Taxodium distichum

Fraxinus pennsylvanica

Planera aquatica

$$
\begin{aligned}
& 41.2 \\
& 17.6 \\
& 17.6 \\
& 11.8 \\
& 11.8 \\
& \hline 100.0
\end{aligned}
$$

100.0

Saplings and Shrubs

Planera aquatica

Woody Vines

None present

Herbs and Woody Seedlings

Quercus lyrata
Gratiola virginiana
Cynoctonum mitreola
Leersia lenticularis
Carya aquatica
Planera aquatica
Taxodium distichum
Vitis palmata
Asclepias perennis
Pilea pumila
Phanopyrum gymocarpon
Nyssa aquatica
Spilanthes americana
Smilax hispida
Nyssa ogeche
Gleditsia aquatica
Forestiera acuminata
Commelina diffusa
Cephalanthus occidentalis

\begin{tabular}{rrrr}
15.1 & - & 17.2 & 32.3 \\
16.4 & - & 12.8 & 29.2 \\
9.6 & - & 18.5 & 28.1 \\
8.2 & - & 11.9 & 20.1 \\
9.6 & - & 7.5 & 17.1 \\
8.2 & - & 6.4 & 14.6 \\
6.8 & - & 5.3 & 12.1 \\
4.1 & - & 3.2 & 7.3 \\
4.1 & - & 3.2 & 7.3 \\
2.7 & - & 2.1 & 4.8 \\
2.7 & - & 2.1 & 4.8 \\
2.7 & - & 2.1 & 4.8 \\
1.4 & - & 1.1 & 2.5 \\
1.4 & - & 1.1 & 2.5 \\
1.4 & - & 1.1 & 2.5 \\
1.4 & - & 1.1 & 2.5 \\
1.4 & - & 1.1 & 2.5 \\
1.4 & - & 1.1 & 2.5 \\
1.4 & - & 1.1 & 2.5 \\
\hline
\end{tabular}

166.1

50.7

39.3

24.7

$\frac{19.2}{300.0}$

$\frac{6.8}{100.0}$

$\frac{0.6}{100.0}$

100.0

300.0

\section{Zone 3}

\section{Trees}

Carya aquatica

Forestiera acuminata

Nyssa aquatica

Fraxinus caroliniana

$\begin{array}{ll}18.6 & 16.7 \\ 14.8 & 31.2 \\ 11.1 & 10.3 \\ 14.8 & 16.7\end{array}$

34.1

69.4

$4.6 \quad 50.6$

$22.0 \quad 43.4$

$4.0 \quad 35.5$ 
Table D-11--continued

\begin{tabular}{|c|c|c|c|c|}
\hline Species & $\begin{array}{c}\text { Percent } \\
\text { Relative } \\
\text { Frequency }\end{array}$ & $\begin{array}{r}\text { Percent } \\
\text { Relative } \\
\text { Density } \\
\end{array}$ & 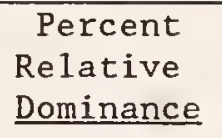 & $\begin{array}{c}\text { Importance } \\
\text { Value }\end{array}$ \\
\hline Nyssa ogeche & 7.4 & 4.2 & 14.6 & 26.2 \\
\hline Quercus lyrata & 7.4 & 4.2 & 10.5 & 22.1 \\
\hline Planera aquatica & 7.4 & 6.2 & 1.0 & 14.6 \\
\hline Gleditsia aquatica & 7.4 & 4.2 & 2.9 & 14.5 \\
\hline Fraxinus pennsylvanica & 3.7 & 2.1 & 5.9 & 11.7 \\
\hline Crataegus viridis & 3.7 & 2.1 & 0.2 & 6.0 \\
\hline \multirow[t]{2}{*}{ Cephalanthus occidentalis } & 3.7 & 2.1 & 0.2 & 6.0 \\
\hline & 100.0 & 100.0 & 100.0 & 300.0 \\
\hline \multicolumn{5}{|l|}{ Saplings and Shrubs } \\
\hline$\overline{\text { Forestiera acuminata }}$ & 26.8 & 56.8 & 55.5 & 139.1 \\
\hline Fraxinus caroliniana & 11.4 & 13.3 & 17.0 & 41.7 \\
\hline Planera aquatica & 15.4 & 13.3 & 12.9 & 41.6 \\
\hline Cephalanthus occidentalis & 15.4 & 5.6 & 5.5 & 26.5 \\
\hline Carya aquatica & 7.7 & 3.3 & 3.7 & 14.7 \\
\hline Fraxinus pennsylvanica & 7.7 & 3.3 & 2.2 & 13.2 \\
\hline Crataegus viridis & 3.9 & 1.1 & 1.4 & 6.4 \\
\hline Quercus lyrata & 3.9 & 1.1 & 1.2 & 6.2 \\
\hline Nyssa ogeche & 3.9 & 1.1 & 0.3 & 5.3 \\
\hline \multirow{2}{*}{ Gleditsia aquatica } & 3.9 & 1.1 & 0.3 & 5.3 \\
\hline & $\overline{100.0}$ & $\overline{100.0}$ & 100.0 & $\overline{300.0}$ \\
\hline \multicolumn{5}{|l|}{ Woody Vines } \\
\hline Brunnichia cirrhosa & 27.0 & 27.5 & 21.8 & 76.3 \\
\hline Vitis riparia & 19.2 & 27.5 & 29.4 & 76.1 \\
\hline Ampelopsis arborea & 23.1 & 13.7 & 22.0 & 58.8 \\
\hline Vitis palmata & 7.7 & 13.7 & 10.2 & 31.6 \\
\hline Campsis radicans & 11.5 & 7.8 & 12.2 & 31.5 \\
\hline Smilax bona-nox & 7.7 & 7.8 & 3.4 & 18.9 \\
\hline \multirow[t]{2}{*}{ Cocculus carolinus } & 3.8 & 2.0 & 1.0 & 6.8 \\
\hline & 100.0 & 100.0 & 100.0 & 300.0 \\
\hline \multicolumn{5}{|l|}{ Herbs and Woody Seedlings } \\
\hline Carya aquatica & 18.0 & - & 25.7 & 43.7 \\
\hline Quercus lyrata & 11.0 & - & 16.1 & 27.1 \\
\hline Leersia lenticularis & 9.0 & -- & 11.7 & 20.7 \\
\hline Brunnichia cirrhosa & 12.0 & - & 7.2 & 19.2 \\
\hline Aster sp. & 7.0 & - & 4.2 & 11.2 \\
\hline Ampelopsis arborea & 5.0 & -- & 6.1 & 11.1 \\
\hline Phanopyrum gymnocarpon & 4.0 & -- & 5.5 & 9.5 \\
\hline Gleditsia aquatica & 5.0 & -- & 3.0 & 8.0 \\
\hline Smilax bona-nox & 3.0 & -- & 4.9 & 7.9 \\
\hline Forestiera acuminata & 4.0 & - & 2.4 & 6.4 \\
\hline Asclepias perennis & 4.0 & -- & 2.4 & 6.4 \\
\hline Toxicodendron radicans & 3.0 & - & 1.8 & 4.8 \\
\hline Planera aquatica & 3.0 & -- & 1.8 & 4.8 \\
\hline Tragia sp. & 2.0 & - & 1.2 & 3.2 \\
\hline
\end{tabular}


Table D-11--continued

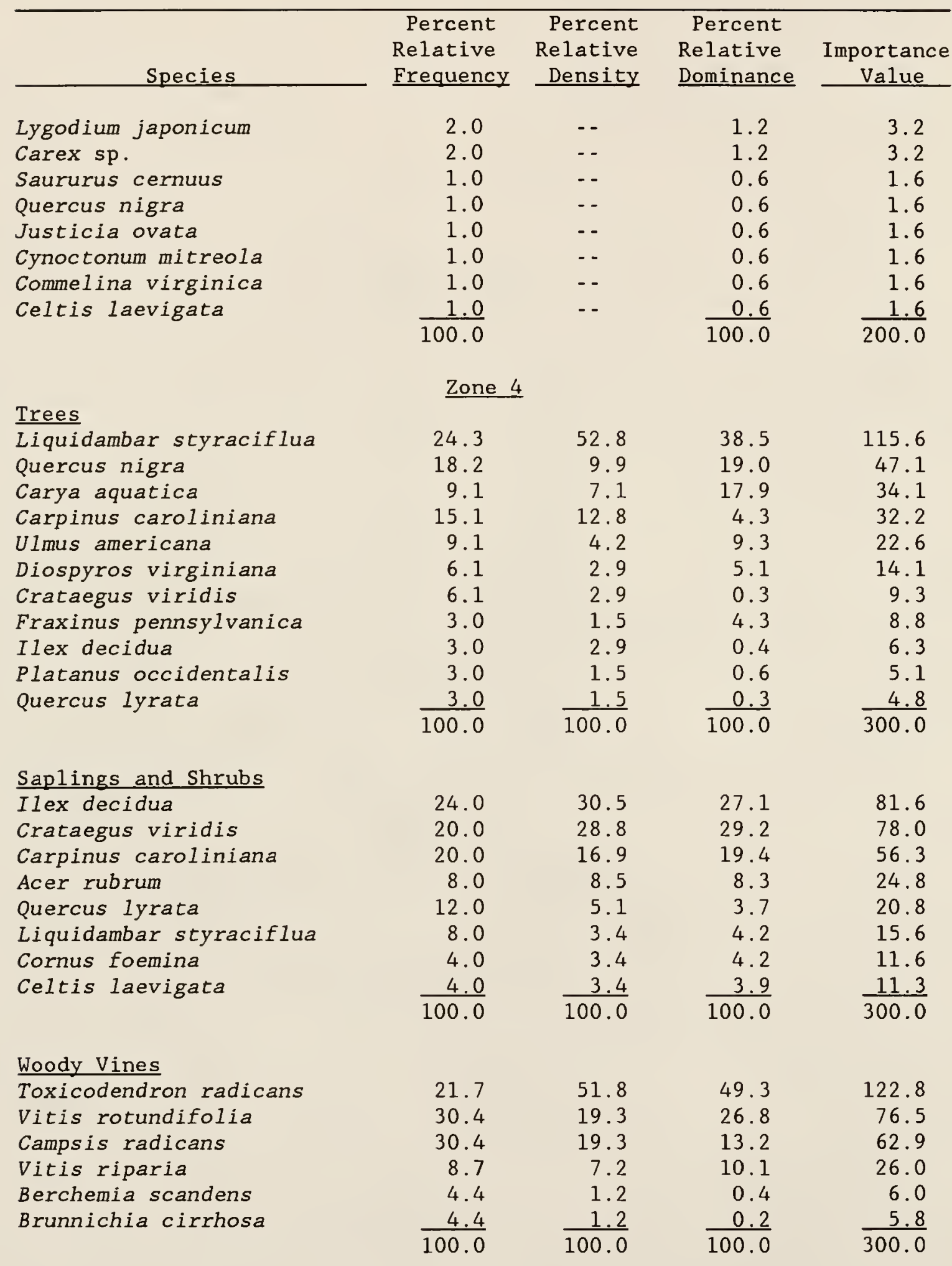


Table D-11--continued

\begin{tabular}{|c|c|c|c|c|}
\hline Species & $\begin{array}{l}\text { Percent } \\
\text { Relative } \\
\text { Frequency }\end{array}$ & $\begin{array}{r}\text { Percent } \\
\text { Relative } \\
\text { Density } \\
\end{array}$ & $\begin{array}{l}\text { Percent } \\
\text { Relative } \\
\text { Dominance }\end{array}$ & $\begin{array}{c}\text { Importance } \\
\text { Value }\end{array}$ \\
\hline \multicolumn{5}{|l|}{ Herbs and Woody Seedlings } \\
\hline Lygodium japonicum & 15.5 & -- & 58.5 & 74.0 \\
\hline Toxicodendron radicans & 12.5 & -- & 5.9 & 18.4 \\
\hline Campsis radicans & 5.2 & - & 3.5 & 8.7 \\
\hline Brunnichia cirrhosa & 6.2 & - & 2.0 & 8.2 \\
\hline Smilax bona-nox & 5.2 & - & 1.7 & 6.9 \\
\hline Justicia ovata & 5.2 & - & 1.7 & 6.9 \\
\hline Ilex decidua & 5.2 & - & 1.7 & 6.9 \\
\hline Botrychium biternatum & 5.2 & - & 1.7 & 6.9 \\
\hline Vitis rotundifolia & 3.1 & - & 2.8 & 5.9 \\
\hline Sebastiania fruticosa & 3.1 & - & 2.8 & 5.9 \\
\hline Oplismenus hirtellus & 3.1 & - & 2.8 & 5.9 \\
\hline Celtis laevigata & 3.1 & $\cdots$ & 2.8 & 5.9 \\
\hline Quercus nigra & 3.1 & - & 1.0 & 4.1 \\
\hline Liquidambar styraciflua & 3.1 & - & 1.0 & 4.1 \\
\hline Sambucus canadensis & 1.0 & - & 2.1 & 3.1 \\
\hline Onoclea sensibilis & 1.0 & -- & 2.1 & 3.1 \\
\hline Melia azedarach & 2.1 & -- & 0.7 & 2.8 \\
\hline Aster sp. & 2.1 & - & 0.7 & 2.8 \\
\hline Woodwardia sp. & 1.0 & - & 0.3 & 1.3 \\
\hline Ulmus alata & 1.0 & - & 0.3 & 1.3 \\
\hline Smilax rotundifolia & 1.0 & - & 0.3 & 1.3 \\
\hline Smilax glauca & 1.0 & $\cdots$ & 0.3 & 1.3 \\
\hline Quercus lyrata & 1.0 & - & 0.3 & 1.3 \\
\hline Phytolacca americana & 1.0 & - & 0.3 & 1.3 \\
\hline Panicum sp. & 1.0 & - & 0.3 & 1.3 \\
\hline Panicum rigidulum & 1.0 & - & 0.3 & 1.3 \\
\hline Geum canadense & 1.0 & - & 0.3 & 1.3 \\
\hline Ageratina altissima & 1.0 & - & 0.3 & 1.3 \\
\hline Diospyros virginiana & 1.0 & -- & 0.3 & 1.3 \\
\hline Commelina virginica & 1.0 & - & 0.3 & 1.3 \\
\hline Carex sp. & 1.0 & - & 0.3 & 1.3 \\
\hline Boehmeria cylindrica & 1.0 & - & 0.3 & 1.3 \\
\hline \multirow[t]{3}{*}{ Acer negundo } & 1.0 & $\cdots$ & 0.3 & 1.3 \\
\hline & 100.0 & & $\overline{100.0}$ & $\overline{200.0}$ \\
\hline & Zone & & & \\
\hline \multicolumn{5}{|l|}{ Trees } \\
\hline Liquidambar styraciflua & 28.2 & 36.7 & 59.2 & 124.1 \\
\hline Carpinus caroliniana & 18.7 & 15.4 & 4.6 & 38.7 \\
\hline Ulmus americana & 12.5 & 11.5 & 6.9 & 30.9 \\
\hline Celtis laevigata & 9.4 & 5.8 & 15.6 & 30.8 \\
\hline Ilex decidua & 9.4 & 11.5 & 2.1 & 23.0 \\
\hline Platanus occidentalis & 3.1 & 1.9 & 6.0 & 11.0 \\
\hline Ulmus rubra & 3.1 & 5.8 & 2.0 & 10.9 \\
\hline Crataegus viridis & 6.3 & 3.8 & 0.4 & 10.5 \\
\hline
\end{tabular}


Table D-11--continued

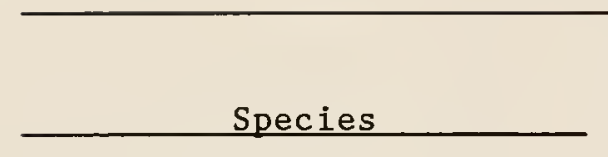

\begin{tabular}{crcr}
$\begin{array}{c}\text { Percent } \\
\text { Relative } \\
\text { Frequency }\end{array}$ & $\begin{array}{c}\text { Percent } \\
\begin{array}{c}\text { Relative } \\
\text { Density }\end{array}\end{array}$ & $\begin{array}{c}\text { Percent } \\
\text { Relative } \\
\text { Dominance }\end{array}$ & $\begin{array}{c}\text { Importanc } \\
\text { Value }\end{array}$ \\
\cline { 5 - 5 } 3.1 & 3.8 & 0.5 & 7.4 \\
3.1 & 1.9 & 1.9 & 6.9 \\
$\frac{3.1}{100.0}$ & $\frac{1.9}{100.0}$ & $\frac{0.8}{100.0}$ & $\frac{5.8}{300.0}$
\end{tabular}

Saplings and Shrubs

Ilex decidua

52.6

80.0

79.0

211.6

10.5

5.0

5.1

20.6

Quercus nigra

Carpinus caroliniana

10.5

5.0

4.7

20.2

10.5

3.3

3.9

17.7

5.3

3.3

3.5

12.1

Ulmus rubra

5.3

1.7

1.9

Cornus foemina

$\frac{5.3}{100.0}$

$\begin{array}{r}1.7 \\ 1.7 \\ \hline 100.0\end{array}$

8.9

$\frac{8.9}{300.0}$

Woody Vines

Vitis rotundifolia

Toxicodendron radicans

21.0

28.8

36.1

28.9

12.3

16.7

Campsis radicans

13.2

11.8

Bignonia capreolata

15.8

9.0

10.5

3.8

7.9

2.3

4.9

1.8

2.8

Brunnichia cirrhosa

Smilax bona-nox

5.3

3.2

$\frac{5.3}{100.0}$

$\frac{2.0}{100.0}$

$\frac{1.4}{100.0}$

85.9

76.3

50.0

36.6

19.2

12.0

11.3

$\frac{8.7}{300.0}$

Herbs and Woody Seedlings

Lygodium japonicum
Campsis radicans
Toxicodendron radicans
Botrychium biternatum
Smilax bona-nox
Carex sp.
Celtis laevigata
Carya aquatica
Aster sp.
Thelypteris kunthii
Bignonia capreolata
Berchemia scandens
Vitis rotundifolia
Rubus trivialis
Polygonum virginianum
Panicum sp.
Ilex decidua
Eupatorium sp.
Decumaria barbara

26.9

12.1

- -

83.4

110.3

4.1

16.2

9.4

2.6

12.0

9.4

1.5

10.9

6.7

2.1

8.8

5.3

1.9

7.2

4.1

0.6

4.7

4.1

0.6

4.7

4.1

0.6

4.7

2.7

0.4

3.1

2.7

0.4

3. 1

2.7

0.4

3.1

1.4

0.2

1.6

1.4

0.2

1.6

1.4

0.2

1.6

1.4

0.2

1.6

1.4

0.2

1.6

1.4

0.2

1.6

1.4

0.2

1.6

100.0

200.0 
Table D-12

Importance Values for Species Occurring at Site 12

Arranged by Zone and Vegetation Layer

\begin{tabular}{l} 
Species \\
\hline \\
Trees \\
Liquidambar styraciflua \\
Ulmus americana \\
Quercus lyrata \\
Celtis laevigata \\
Taxodium distichum \\
Melia azedarach \\
Forestiera acuminata \\
Planera aquatica \\
Acer rubrum
\end{tabular}

\begin{tabular}{|c|c|c|c|}
\hline $\mathrm{Pel}$ & Percent & Percent & \\
\hline $\operatorname{Re} 1$ & Relative & Relative & Impor \\
\hline Frequency & Density & Dominance & Valu \\
\hline
\end{tabular}

Zone 4

\begin{tabular}{rrrr}
50.0 & 69.0 & 68.5 & 187.5 \\
15.0 & 6.8 & 11.5 & 33.3 \\
5.0 & 4.4 & 6.3 & 15.7 \\
5.0 & 4.4 & 4.5 & 13.9 \\
5.0 & 2.2 & 4.7 & 11.9 \\
5.0 & 4.4 & 2.5 & 11.9 \\
5.0 & 4.4 & 0.4 & 9.8 \\
5.0 & 2.2 & 1.4 & 8.6 \\
5.0 & 2.2 & 0.2 & 7.4 \\
\hline 100.0 & 100.0 & 100.0 & 300.0
\end{tabular}

Saplings and Shrubs

Ilex decidua
Liquidambar styraciflua
Celtis laevigata
Forestiera acuminata
Fraxinus pennsylvanica
Sebastiania fruticosa
Sambucus canadensis
Taxodium distichum
Quercus lyrata
Platanus occidentalis
Halesia diptera
Ulmus alata
Acer rubrum
Lindera benzoin

24.3

52.4

45.6

122.3

21.3

12.4

15.2

8.6

3.0

6.3

6.1

3.7

6.1

5.0

3.0

2.5

3.0

3.0

3. 0

1.3

1. 3

3.0

1.3

3.0

1. 3

3.0

1.3

19.2

52.9

5.8

29.6

9.6

18.9

4.4

14.2

2.4

13.5

1.0

6.5

1.9

6.2

1.9

6.2

1.9

6.2

1.6

5.9

1.6

5.9

1.3

1.6

5.9

$\frac{3.0}{100.0}$

$\frac{1.3}{100.0}$

$\frac{1.2}{100.0}$

$\frac{5.5}{300.0}$

Woody Vines

Toxicodendron radicans

Vitis rotundifolia

21.4

39.5

44.1

105.0

23.8

28.5

29.2

81.5

19.0

10.5

Campsis radicans

14.3

8.1

11.9

7.6

$V$ itis riparia

Smilax rotundifolia

Berchemia scandens

4.8

4.1

2.4

1.1

11.0

7.4

2.4

5.2

0.4

40.5

29.8

21.9

14.0

$\frac{2.4}{100.0}$

$\frac{0.6}{100.0}$

3.9

$\frac{0.4}{100.0}$

$\frac{3.4}{300.0}$

Herbs and Woody Seedlings 
Table D-12--continued

\begin{tabular}{|c|c|c|c|c|}
\hline Species & $\begin{array}{l}\text { Percent } \\
\text { Relative } \\
\text { Frequency }\end{array}$ & $\begin{array}{r}\text { Percent } \\
\text { Relative } \\
\text { Density } \\
\end{array}$ & 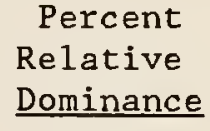 & $\begin{array}{c}\text { Importance } \\
\text { Value }\end{array}$ \\
\hline Toxicodendron radicans & 8.2 & -- & 17.6 & 25.8 \\
\hline Smilax bona-nox & 8.2 & -- & 16.8 & 25.0 \\
\hline Carya aquatica & 9.2 & $\cdots$ & 8.6 & 17.8 \\
\hline Aster sp. & 10.3 & -- & 6.1 & 16.4 \\
\hline Celtis laevigata & 8.2 & -- & 4.9 & 13.1 \\
\hline Lygodium japonicum & 6.1 & -- & 6.8 & 12.9 \\
\hline Campsis radicans & 6.1 & -- & 6.8 & 12.9 \\
\hline Quercus nigra & 6.1 & - & 3.7 & 9.9 \\
\hline Carex sp. & 5.1 & -- & 3.0 & 8.1 \\
\hline Quercus lyrata & 4.1 & -- & 2.4 & 6.5 \\
\hline Fraxinus pennsylvanica & 3.1 & - & 1.8 & 4.9 \\
\hline Triadenum walteri & 2.0 & -- & 1.2 & 3.2 \\
\hline Smilax hispida & 2.0 & $\cdots$ & 1.2 & 3.2 \\
\hline Ilex decidua & 2.0 & - & 1.2 & 3.2 \\
\hline Carex intumescens & 2.0 & $\cdots$ & 1.2 & 3.2 \\
\hline Berchemia scandens & 2.0 & -- & 1.2 & 3.2 \\
\hline Ulmus americana & 1.0 & -- & 0.6 & 1.6 \\
\hline Pilea pumila & 1.0 & - & 0.6 & 1.6 \\
\hline \multirow[t]{2}{*}{ Diospyros virginiana } & 1.0 & -- & 0.6 & 1.6 \\
\hline & $\overline{100.0}$ & & 100.0 & 200.0 \\
\hline
\end{tabular}

Zone 5

\section{Trees}

Liquidambar styraciflua

Melia azedarach

Quercus nigra

Ulmus americana

Carpinus caroliniana

Halesia diptera

Celtis laevigata

Fraxinus pennsylvanica

Acer negundo

Morus rubra

Diospyros virginiana

Ilex decidua

Crataegus viridis

Saplings and Shrubs

Ilex decidua

Celtis laevigata

Crataegus viridis

Sambucus canadensis

Liquidambar styraciflua

Fraxinus pennsylvanica

Quercus nigra

\begin{tabular}{rrrr}
26.8 & 25.4 & 32.5 & 84.7 \\
23.4 & 37.1 & 10.9 & 71.4 \\
6.7 & 5.9 & 31.3 & 43.9 \\
10.0 & 5.9 & 17.4 & 33.3 \\
6.7 & 5.9 & 3.4 & 16.0 \\
3.3 & 3.9 & 0.7 & 7.9 \\
3.3 & 3.9 & 0.5 & 7.7 \\
3.3 & 2.0 & 0.9 & 6.2 \\
3.3 & 2.0 & 0.8 & 5.9 \\
3.3 & 2.0 & 0.6 & 5.9 \\
3.3 & 2.0 & 0.5 & 5.8 \\
3.3 & 2.0 & 0.3 & 5.6 \\
3.3 & 2.0 & 0.2 & 5.5 \\
\hline 100.0 & 100.0 & 100.0 & 300.0
\end{tabular}

13.6

32.2

32.8

78.6

9.5

10.6

10.0

30.1

9.5

9.5

8.1

7.8

5.2

25.4

8.6

24.0

6.8

4.6

22.2

8.1

4.9

4.2

17.6

12.8 
Table D-12--continued

\begin{tabular}{|c|c|c|c|c|}
\hline Species & 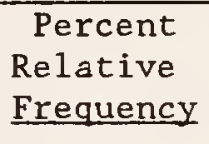 & $\begin{array}{r}\text { Percent } \\
\text { Relative } \\
\text { Density } \\
\end{array}$ & $\begin{array}{l}\text { Percent } \\
\text { Relative } \\
\text { Dominance } \\
\end{array}$ & $\begin{array}{c}\text { Importance } \\
\text { Value } \\
\end{array}$ \\
\hline Ulmus rubra & 4.1 & 4.3 & 3.7 & 12.1 \\
\hline Halesia diptera & 2.8 & 3.7 & 5.4 & 11.9 \\
\hline Ulmus alata & 5.5 & 3.1 & 3.0 & 11.6 \\
\hline Callicarpa americana & 5.5 & 3.1 & 2.7 & 11.3 \\
\hline Lindera benzoin & 2.8 & 2.4 & 2.3 & 7.5 \\
\hline Nyssa sylvatica & 1.4 & 1.2 & 1.8 & 4.4 \\
\hline Carpinus caroliniana & 1.4 & 1.2 & 1.8 & 4.4 \\
\hline Ulmus americana & 1.4 & 0.6 & 0.9 & 2.9 \\
\hline Melia azedarach & 1.4 & 0.6 & 0.9 & 2.9 \\
\hline Carya illinoensis & 1.4 & 0.6 & 0.9 & 2.9 \\
\hline Acer rubrum & 1.4 & 0.6 & 0.9 & 2.9 \\
\hline Bumelia lanuginosa & 1.4 & 0.6 & 0.7 & 2.7 \\
\hline Quercus michauxii & 1.4 & 0.6 & 0.6 & 2.6 \\
\hline Ilex opaca & 1.4 & 0.6 & 0.4 & 2.4 \\
\hline Acer negundo & 1.4 & 0.6 & 0.4 & 2.4 \\
\hline Morus rubra & 1.4 & 0.6 & 0.2 & 2.2 \\
\hline \multirow{2}{*}{ Diospyros virginiana } & 1.4 & 0.6 & 0.2 & 2.2 \\
\hline & $\overline{100.0}$ & $\overline{100.0}$ & $\overline{100.0}$ & $\overline{300.0}$ \\
\hline \multicolumn{5}{|l|}{ Woody Vines } \\
\hline Vitis rotundifolia & 25.6 & 46.7 & 50.3 & 122.6 \\
\hline Toxicodendron radicans & 23.1 & 36.8 & 39.5 & 99.4 \\
\hline Bignonia capreolata & 12.8 & 6.4 & 4.1 & 23.3 \\
\hline Smilax rotundifolia & 12.8 & 4.6 & 2.6 & 20.0 \\
\hline Smilax bona-nox & 10.3 & 2.7 & 1.0 & 14.0 \\
\hline Berchemia scandens & 7.7 & 1.4 & 1.6 & 10.7 \\
\hline \multirow{2}{*}{ Brunnichia cirrhosa } & -7.7 & 1.4 & 0.9 & 10.0 \\
\hline & $\overline{100.0}$ & $\overline{100.0}$ & $\overline{100.0}$ & $\overline{300.0}$ \\
\hline \multicolumn{5}{|l|}{ Herbs and Woody Seedlings } \\
\hline Lygodium japonicum & 9.6 & - & 31.4 & 41.0 \\
\hline Polygonum sp. & 3.0 & -- & 12.1 & 15.1 \\
\hline Toxicodendron radicans & 8.1 & - & 5.3 & 13.4 \\
\hline Oplismenus hirtellus & 5.3 & -- & 6.9 & 12.2 \\
\hline Quercus nigra & 5.3 & - & 5.7 & 11.0 \\
\hline Sambucus canadensis & 5.3 & - & 4.0 & 9.3 \\
\hline Rubus argutus & 5.3 & -- & 2.3 & 7.6 \\
\hline Rubus trivialis & 3.7 & - & 3.3 & 7.0 \\
\hline Bignonia capreolata & 3.7 & - & 3.3 & 7.0 \\
\hline Aster sp. & 4.4 & - & 2.0 & 6.4 \\
\hline Ilex decidua & 3.0 & -- & 3.0 & 6.0 \\
\hline Elytraria carolinensis & 3.0 & - & 3.0 & 6.0 \\
\hline Smilax bona-nox & 3.7 & - & 1.6 & 5.3 \\
\hline Geum canadense & 3.7 & -- & 1.6 & 5.3 \\
\hline Celtis laevigata & 3.7 & - & 1.6 & 5.3 \\
\hline Botrychium biternatum & 3.7 & -- & 1.6 & 5.3 \\
\hline Ulmus alata & 3.0 & -- & 1.3 & 4.3 \\
\hline
\end{tabular}


Table D-12--continued

\begin{tabular}{|c|c|c|c|c|}
\hline Species & $\begin{array}{c}\text { Percent } \\
\text { Relative } \\
\text { Frequency }\end{array}$ & $\begin{array}{r}\text { Percent } \\
\text { Relative } \\
\text { Density } \\
\end{array}$ & $\begin{array}{l}\text { Percent } \\
\text { Relative } \\
\text { Dominance }\end{array}$ & $\begin{array}{c}\text { Importance } \\
\text { Value } \\
\end{array}$ \\
\hline Carex sp. & 3.0 & -- & 1.3 & 4.3 \\
\hline Liquidambar styraciflua & 2.2 & -- & 1.0 & 3.2 \\
\hline Argeratina altissima & 2.2 & -- & 1.0 & 3.2 \\
\hline Smilax rotundifolia & 1.5 & -- & 0.7 & 2.2 \\
\hline Panicum sp. & 1.5 & $\cdots$ & 0.7 & 2.2 \\
\hline Morus rubra & 1.5 & - & 0.7 & 2.2 \\
\hline Acer negundo & 1.5 & - & 0.7 & 2.2 \\
\hline Solidago altissima & 0.7 & -- & 0.3 & 1.0 \\
\hline Quercus phellos & 0.7 & - & 0.3 & 1.0 \\
\hline Phytolacca americana & 0.7 & -- & 0.3 & 1.0 \\
\hline Lindera benzoin & 0.7 & - & 0.3 & 1.0 \\
\hline Lespedeza sp. & 0.7 & -- & 0.3 & 1.0 \\
\hline Duchesnia indica & 0.7 & - & 0.3 & 1.0 \\
\hline Diospyros virginiana & 0.7 & -- & 0.3 & 1.0 \\
\hline Crataegus viridis & 0.7 & -- & 0.3 & 1.0 \\
\hline Cornus foemina & 0.7 & -- & 0.3 & 1.0 \\
\hline Commelina diffusa & 0.7 & -- & 0.3 & 1.0 \\
\hline Cocculus carolinus & 0.7 & -- & 0.3 & 1.0 \\
\hline Callicarpa americana & 0.7 & -- & 0.3 & 1.0 \\
\hline \multirow[t]{2}{*}{ Brunnichia cirrhosa } & 0.7 & - & 0.3 & 1.0 \\
\hline & $\overline{100.0}$ & & 100.0 & $\overline{200.0}$ \\
\hline
\end{tabular}

Zone 6

\section{Trees}

Liquidambar styraciflua

Betula nigra

Carya illinoensis

Ulmus alata

Juglans nigra

Halesia carolina

Melia azedarach

Sassafras albidum

Quercus nigra

Bumelia lanuginosa

Ulmus americana

Diospyros virginiana

Celtis laevigata

Halesia diptera

Saplings and Shrubs

Ulmus alata

Liquidambar styraciflua

Celtis laevigata

Quercus nigra

Callicarpa americana
30.4

9.1

3.0

6.1

9.1

9.1

9.1

6.1

3.0

3.0

3.0

3.0

3.0

$\frac{3.0}{100.0}$

10.7

8.5

9.7

8.5

8.5
59.2

6.8

1.7

3.4

5.1

5.1

5.1

3.4

1.7

1.7

1.7

1.7

1.7

$\frac{1.7}{100.0}$

22.6

10 .

12.3

8.5

7.6
44.4

7.2

16.9

11.5

6.4

1.4

1.3

1.2

4.3

2.0

1.7

0.9

0.5

$\frac{0.3}{100.0}$

18.2

15.6

10.3

9.6

5.9
134.0

23.1

21.6

21.0

20.6

15.6

15.5

10.7

9.0

6.7

6.4

5.6

5.2

$\frac{5.0}{300.0}$
51.5

34.5

32.3

26.6

22.0 
Table D-12--continued

\begin{tabular}{|c|c|c|c|c|}
\hline Species & 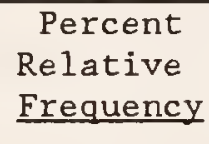 & $\begin{array}{r}\text { Percent } \\
\text { Relative } \\
\text { Density } \\
\end{array}$ & $\begin{array}{r}\text { Percent } \\
\text { Relative } \\
\text { Dominance } \\
\end{array}$ & $\begin{array}{c}\text { Importance } \\
\text { Value }\end{array}$ \\
\hline Halesia carolina & 5.4 & 4.2 & 7.1 & 16.7 \\
\hline Sebastiania fruticosa & 5.4 & 6.6 & 3.5 & 15.5 \\
\hline Lindera benzoin & 6.5 & 4.2 & 3.3 & 14.0 \\
\hline Acer negundo & 5.4 & 3.8 & 2.8 & 12.0 \\
\hline Halesia diptera & 4.3 & 2.8 & 4.8 & 11.9 \\
\hline Ilex decidua & 4.3 & 3.8 & 3.0 & 11.1 \\
\hline Cornus foemina & 4.3 & 3.8 & 3.0 & 11.1 \\
\hline Ulmus americana & 3.2 & 1.9 & 2.2 & 7.3 \\
\hline Melia azedarach & 3.2 & 1.4 & 2.4 & 7.0 \\
\hline Juglans nigra & 2.2 & 0.9 & 1.6 & 4.7 \\
\hline Gleditsia triacanthos & 2.2 & 0.9 & 1.0 & 4.1 \\
\hline Betula nigra & $q \cdot q$ & 0.9 & 1.6 & 3.6 \\
\hline Sambucus canadensis & 1.1 & 0.9 & 1.3 & 3.3 \\
\hline Platanus occidentalis & 1.1 & 0.5 & 0.8 & 2.4 \\
\hline Ilex opaca & 1.1 & 0.5 & 0.6 & 2.2 \\
\hline Acer rubrum & 1.1 & 0.5 & 0.6 & 2.2 \\
\hline Quercus phellos & 1.1 & 0.5 & 0.5 & 2.1 \\
\hline \multirow[t]{2}{*}{ Bumelia lanuginosa } & 1.1 & 0.5 & 0.3 & 1.9 \\
\hline & 100.0 & 100.0 & 100.0 & 300.0 \\
\hline \multicolumn{5}{|l|}{ Woody Vines } \\
\hline Clematis ligusticifolia & 16.0 & 23.7 & 25.9 & 65.6 \\
\hline Bignonia capreolata & 17.9 & 24.1 & 21.4 & 63.4 \\
\hline Aristolochia tomentosa & 14.3 & 15.6 & 15.4 & 45.3 \\
\hline Vitis rotundifolia & 17.9 & 11.1 & 14.1 & 43.1 \\
\hline Toxicodendron radicans & 8.9 & 13.0 & 14.8 & 36.7 \\
\hline Smilax rotundifolia & 12.5 & 9.0 & 4.9 & 26.4 \\
\hline Campsis radicans & 7.1 & 1.9 & 2.5 & 11.5 \\
\hline Ampelopsis arborea & 1.8 & 1.2 & 0.8 & 3.8 \\
\hline Lonicera japonica & 1.8 & 0.2 & 0.1 & 2.1 \\
\hline \multirow[t]{2}{*}{ Parthenocissus quinquefolia } & 1.8 & 0.2 & 0.1 & 2.1 \\
\hline & 100.0 & 100.0 & 100.0 & 300.0 \\
\hline \multicolumn{5}{|l|}{ Herbs and Woody Seedlings } \\
\hline Oplismenus hirtellus & 7.7 & -- & 27.2 & 34.9 \\
\hline Bignonia capreolata & 9.3 & -- & 9.0 & 18.3 \\
\hline Carex sp. & 7.1 & - & 10.4 & 17.5 \\
\hline Ageratina altissima & 9.3 & -- & 7.9 & 17.2 \\
\hline Panicum sp. & 8.7 & -- & 3.5 & 12.2 \\
\hline Quercus nigra & 4.6 & -- & 6.9 & 11.5 \\
\hline Acer negundo & 5.1 & -- & 5.2 & 10.3 \\
\hline Hyptis mutabilis & 4.1 & -- & 4.8 & 8.9 \\
\hline Sebastiania fruticosa & 4.1 & - & 3.8 & 7.9 \\
\hline Elytraria carolinensis & 4.1 & -- & 2.7 & 6.8 \\
\hline Sambucus canadensis & 3.6 & - & 2.5 & 6.1 \\
\hline Toxicodendron radicans & 4.1 & -- & 1.6 & 5.7 \\
\hline Celtis laevigata & 3.6 & - & 1.4 & 5.0 \\
\hline
\end{tabular}


Table D-12--continued

\begin{tabular}{|c|c|c|c|c|}
\hline Species & 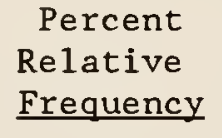 & $\begin{array}{r}\text { Percent } \\
\text { Relative } \\
\text { Density } \\
\end{array}$ & $\begin{array}{l}\text { Percent } \\
\text { Relative } \\
\text { Dominance }\end{array}$ & $\begin{array}{c}\text { Importance } \\
\text { Value } \\
\end{array}$ \\
\hline $\begin{array}{l}\text { Geum canadense } \\
\text { Ulmus alata } \\
\text { Quercus phellos } \\
\text { Rubus trivialis } \\
\text { Lindera benzoin } \\
\text { Viburnum cassinoides } \\
\text { Dichondra carolinensis } \\
\text { Callicarpa americana } \\
\text { Smilax rotundifolia } \\
\text { Lygodium japonicum } \\
\text { Bumelia lanuginosa } \\
\text { Clematis ligusticifolia } \\
\text { Vitis rotundifolia } \\
\text { Sassafras albidum } \\
\text { Toxicodendron radicans } \\
\text { Polygonum sp. } \\
\text { Paspalum sp. } \\
\text { Parthenocissus quinquefolia } \\
\text { Onoclea sensibilis } \\
\text { Lonicera japonica } \\
\text { Lindera benzoin } \\
\text { Lactuca serriola } \\
\text { Ilex decidua } \\
\text { Cercis canadensis } \\
\text { Agrostis hyemalis } \\
\text { Amaranthus tuberculatus }\end{array}$ & $\begin{array}{r}3.1 \\
1.5 \\
1.5 \\
2.0 \\
2.0 \\
1.5 \\
1.5 \\
0.5 \\
1.0 \\
1.0 \\
1.0 \\
1.0 \\
0.5 \\
0.5 \\
0.5 \\
0.5 \\
0.5 \\
0.5 \\
0.5 \\
0.5 \\
0.5 \\
0.5 \\
0.5 \\
0.5 \\
0.5 \\
0.5 \\
100.0\end{array}$ & $\begin{array}{l}-- \\
-- \\
-- \\
-- \\
-- \\
-- \\
-- \\
-- \\
-- \\
-- \\
-- \\
-- \\
-- \\
-- \\
-- \\
-- \\
-- \\
-- \\
-- \\
-- \\
-- \\
-- \\
-- \\
--\end{array}$ & $\begin{array}{r}1.2 \\
1.7 \\
1.7 \\
0.8 \\
0.8 \\
0.6 \\
0.6 \\
1.3 \\
0.4 \\
0.4 \\
0.4 \\
0.4 \\
0.2 \\
0.2 \\
0.2 \\
0.2 \\
0.2 \\
0.2 \\
0.2 \\
0.2 \\
0.2 \\
0.2 \\
0.2 \\
0.2 \\
0.2 \\
0.2 \\
100.0\end{array}$ & $\begin{array}{l}4.3 \\
3.2 \\
3.2 \\
2.8 \\
2.8 \\
2.1 \\
2.1 \\
1.8 \\
1.4 \\
1.4 \\
1.4 \\
1.4 \\
0.7 \\
0.7 \\
0.7 \\
0.7 \\
0.7 \\
0.7 \\
0.7 \\
0.7 \\
0.7 \\
0.7 \\
0.7 \\
0.7 \\
0.7 \\
0.7 \\
200.0\end{array}$ \\
\hline
\end{tabular}


Table D-13

Importance Values for Species Occurring at Site 13.

Arranged by Zone and Vegetation Layer

Species

Percent Percent Percent

Relative Relative Relative Importance

Frequency Density Dominance

Value

\section{Zone 2}

\section{Trees}

Planera aquatica

Taxodium distichum

Nyssa aquatica

Fraxinus caroliniana

Quercus Iyrata

Saplings and Shrubs

Fraxinus caroliniana

Planera aquatica

Styrax americana

Woody Vines

Brunnichia cirrhosa

Campsis radicans

Smilax bona-nox

Ampelopsis arborea

Herbs and Woody Seedlings

Dichanthelium commutatum

Ampelopsis arborea

Brunnichia cirrohosa

Ulmus americana

Nyssa aquatica

Carex sp.

Carya aquatica

Styrax americana

Quercus lyrata

Planera aquatica

Liquidambar styraciflua

Aster sp.

$\begin{array}{r}30.8 \\ 30.8 \\ 15.4 \\ 19.2 \\ 3.8 \\ \hline 100.0\end{array}$

37.5

50.0

$\frac{12.5}{100.0}$

100.0

50.0

12.5

12.5

$\frac{25.0}{100.0}$

22.0

12.2

9.8

14.6

9.8

7.3

7.3

4.9

4.9

2.4

2.4

$\frac{2.4}{100.0}$

Zone 3
44.4

25.5

42.3

30.1

2.0

13.3

17.8

$\frac{2.3}{100.0}$

$\frac{0.1}{100.0}$

44.4

27.8

$\frac{27.8}{100.0}$

50.0

20.0

23.3

$\frac{6.7}{100.0}$

54.5

30.1

$\frac{15.4}{100.0}$

41.2

34.1

17.7

$\frac{7.1}{100.0}$

17.5

19.9

18.0

11.7

7.8

5.8

5.8

3.9

3.9

1.9

1.9

$\frac{1.9}{100.0}$
100.7

95.3

58.8

39.0

$\frac{6.2}{300.0}$

136.4

107.9

$\frac{55.7}{300.0}$

141.1

66.6

53.5

$\frac{38.8}{300.0}$

Trees

Quercus Iyrata

21.1

35.8

18.1

75.0

18.2

15.1

18.6

51.9

15.2

11.3

21.2

47.7 
Table D-13--continued

Species

Betula nigra

Carya aquatica

Taxodium distichum

Acer rubrum

Ulmus americana

Fraxinus pennsylvanica

$\begin{array}{crcr}\begin{array}{c}\text { Percent } \\ \text { Relative } \\ \text { Frequency }\end{array} & \begin{array}{r}\text { Percent } \\ \text { Relative } \\ \text { Density }\end{array} & \begin{array}{c}\text { Percent } \\ \text { Relative } \\ \text { Dominance }\end{array} & \begin{array}{c}\text { Importance } \\ \text { Dalue }\end{array} \\ 12.1 & 9.4 & 17.3 & 38.8 \\ 15.2 & 11.3 & 7.8 & 34.3 \\ 3.0 & 5.7 & 9.4 & 18.1 \\ 6.1 & 5.7 & 2.6 & 14.4 \\ 6.1 & 3.8 & 3.4 & 13.3 \\ \frac{3.0}{100.0} & \frac{1.9}{100.0} & \frac{1.6}{100.0} & \frac{6.6}{300.0}\end{array}$

Saplings and Shrubs

Quercus lyrata

Fraxinus caroliniana

Nyssa aquatica

Planera aquatica

Styrax americana

\begin{tabular}{rrrr}
40.0 & 38.4 & 50.5 & 128.9 \\
20.0 & 30.8 & 23.9 & 74.7 \\
20.0 & 15.4 & 18.3 & 53.7 \\
10.0 & 7.7 & 4.6 & 22.3 \\
10.0 & $\frac{7.7}{100.0}$ & $\frac{2.7}{100.0}$ & $\underline{20.4}$ \\
\hline 100.0 & 100.0
\end{tabular}

Woody Vines

Brunnichia cirrhosa

33.3

20.0

36.0

89.3

22.3

35.0

23.0

80.3

Ampelopsis arborea

33.3

30.0

14.0

77.3

Vitis rotundifolia

$\frac{11.1}{100.0}$

$\frac{15.0}{100.0}$

$\frac{27.0}{100.0}$

$\frac{53.1}{300.0}$

Herbs and Woody Seedlings

Dichanthelium commutatum

Ampelops is arborea

Ulmus americana

16.6

$-$

14.9

31.5

9.4

19.6

29.0

14.3

$-$

12.7

27.0

Quercus lyrata

14.3

$-$

12.7

27.0

Carya aquatica

14.3

12.7

27.0

7.1

$-\cdot$

6.4

13.5

4.8

4.2

9.0

4.8

4.2

9.0

2.4

2.1

4.5

2.4

2.1

4.5

2.4

2.1

4.5

2.4

2.1

4.5

2.4

2.1

4.5

Eupatorium serotinum

$\frac{2.4}{100.0}$

$\frac{2.1}{100.0}$

$\frac{4.5}{200.0}$

Zone 4

Trees

Liquidambar styraciflua

33.4

37.6

27.9

98.9

20.0

22.9

53.2

96.1

Carpinus caroliniana

16.7

21.2

4.1

42.0

6.7

3. 3

3.7

13.7 
Table D-13--continued

Species

\begin{tabular}{cccc} 
Percent & Percent & Percent & \\
Relative & Relative & Relative & Importance \\
Frequency & Density & Dominance & Value \\
\cline { 2 - 3 } & & &
\end{tabular}

U1mus americana

Quercus phellos

Quercus lyrata

Quercus falcata var.

pagodifolia

Nyssa sylvatica

Ilex decidua

\begin{tabular}{rrrr}
3.3 & 3.3 & 4.8 & 11.4 \\
6.7 & 3.3 & 1.1 & 11.1 \\
3.3 & 3.3 & 1.1 & 7.7 \\
3.3 & 1.7 & 2.7 & 7.7 \\
3.3 & 1.7 & 1.2 & 6.2 \\
3.3 & 1.7 & 0.2 & $\frac{5.2}{300.0}$ \\
\hline 100.0 & 100.0 & 100.0 & \\
& & & \\
36.0 & 64.4 & 66.3 & 166.7 \\
24.0 & 16.9 & 16.1 & 57.0 \\
16.0 & 8.5 & 8.8 & 33.3 \\
4.0 & 1.7 & 1.8 & 7.5 \\
4.0 & 1.7 & 1.8 & 7.5 \\
4.0 & 1.7 & 1.8 & 7.5 \\
4.0 & 1.7 & 1.8 & 7.5 \\
4.0 & 1.7 & 1.1 & 6.8 \\
4.0 & 1.7 & 0.5 & 6.2 \\
\hline 100.0 & 100.0 & 100.0 & 300.0 \\
& & & \\
45.4 & 67.7 & 69.6 & 182.7 \\
36.4 & 22.0 & 26.0 & 84.4 \\
9.1 & 5.9 & 1.6 & 16.6 \\
9.1 & 4.4 & 2.8 & 16.3 \\
\hline 100.0 & 100.0 & 100.0 & 300.0
\end{tabular}

Saplings and Shrubs

Carpinus caroliniana

Ilex decidua

Ulmus americana

Quercus michauxii

Nyssa sylvatica

Liquidambar styraciflua

Acer rubrum

Styrax americana

Quercus nigra

Woody Vines

Toxicodendron radicans

$V$ itis rotundifolia

Berchemia scandens

Smilax rotundifolia

Herbs and Woody Seedlings

Sabal minor
Ulmus americana
Smilax rotundifolia
Carpinus caroliniana
Quercus nigra
Dichanthelium commutatum
Botrychium biternatum
Acer rubrum
Toxicodendron radicans
Carex sp.
Panicum sp.
Bignonia capreolata
Vitis rotundifolia
Mitchella repens
Liquidambar styraciflua
Ilex decidua
Elytraria carolinensis
Carya tomentosa

- -

25.2

30.7

10.9

8.6

19.5

9.6

8.6

19.5

8.2

7.6

17.2

6.5

14.7

8.2

6.5

14.7

8.2

6.5

14.7

8.2

6.5

14.7

6.8

5.4

12.2

4.1

3.2

7.3

2.7

2.2

4.9

2.7

2.2

4.9

1.4

1.1

2.5

1.4

1.1

2.5

1.4

1.1

2.5

1.4

1.1

2.5

1.4

1.1

2.5

1.4

1.1

2.5 
Table D-13--continued

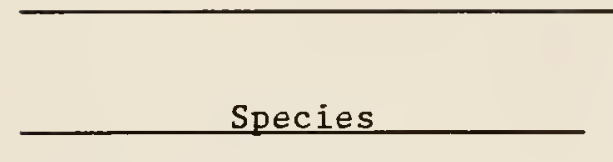

\begin{tabular}{cccc}
$\begin{array}{c}\text { Percent } \\
\text { Relative } \\
\text { Frequency }\end{array}$ & $\begin{array}{c}\text { Percent } \\
\text { Relative } \\
\text { Density }\end{array}$ & $\begin{array}{c}\text { Percent } \\
\text { Relative } \\
\text { Dominance }\end{array}$ & $\begin{array}{c}\text { Importance } \\
\text { Value }\end{array}$ \\
\cline { 2 - 3 } 1.4 & -- & 1.1 & 2.5 \\
1.4 & -- & 1.1 & 2.5 \\
1.4 & -- & 1.1 & 2.5 \\
$\frac{1.4}{100.0}$ & -- & $\frac{1.1}{100.0}$ & $\frac{2.5}{200.0}$
\end{tabular}

Zone 6

\section{Trees}

Pinus glabra

Pinus taeda

Carya tomentosa

Ulmus alata

Quercus falcata var.

pagodifolia

Liquidambar styraciflua

Nyssa sylvatica

Quercus alba

Carpinus caroliniana

Quercus nigra

Quercus stellata

18.3

15.8

10.5

13.2

5.3

7.9

7.9

5.3

5.3

5.3

2.6

Morus rubra

Saplings and Shrubs

Carpinus caroliniana
Ulmus alata
Vaccinium arboreum
Crataegus marshallii
Ilex decidua
Asimina parviflora
Carya tomentosa
Vaccinium elliottii
Arundinaria gigantea
Nyssa sylvatica
Cornus drummondii
Liquidambar styraciflua
Quercus michauxii
Pinus taeda
Quercus falcata var.
$\quad$ pagodifolia
Ulmus americana
Quercus phellos
Quercus nigra
Amelanchier arborea
Ilex opaca
Carya glabra

12.7

12.7

7.7

9.0

7.7

9.0

6.4

3. 8

3.8

3.8

2.6

2.6

2.6

2.6

2.6

1.3

1. 3

1.3

1. 3

1.3

1.3
23.8

12.7

16.4

12.7

5.4

7.3

5.5

3.6

5.4

3.6

1.8

$\frac{1.8}{100.0}$

28.3

15.7

14.9

7.7

5.5

5.0

3.1

4.5

3.6

2. 3

1.8

1.3

1.3

0.9

0.9

0.4

0.4

0.4

0.4

0.4

0.4

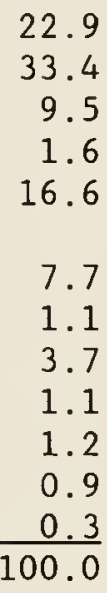

65.0

61.9

36.4

27.5

27.3

22.9

14.5

12.6

11.8

10. 1

5. 3

$\frac{4.7}{300.0}$

72.6

46.4

34.2

22.7

19.6

18.6

13.2

11.7

9.2

9.0

5.7

5. 3

5.2

4.8

1. 3

4.2

0.7

0.7

0.7

2.4

2.4

2.4

2.4

2.1

2.0 
Table D-13--continued

\begin{tabular}{|c|c|c|c|c|}
\hline Species & $\begin{array}{c}\text { Percent } \\
\text { Relative } \\
\text { Frequency } \\
\end{array}$ & $\begin{array}{r}\text { Percent } \\
\text { Relative } \\
\text { Density } \\
\end{array}$ & \begin{tabular}{l}
\multicolumn{1}{c}{ Percent } \\
Relative \\
Dominance \\
\end{tabular} & $\begin{array}{c}\text { Importance } \\
\text { Value } \\
\end{array}$ \\
\hline Asimina triloba & 1.3 & 0.4 & 0.3 & 2.0 \\
\hline Malus coronaria & 1.3 & 0.4 & 0.2 & 1.9 \\
\hline & 100.0 & 100.0 & $\overline{100.0}$ & $\overline{300.0}$ \\
\hline \multicolumn{5}{|l|}{ Woody Vines } \\
\hline Vitis rotundifolia & 27.7 & 40.9 & 44.9 & 113.5 \\
\hline Toxicodendron radicans & 27.7 & 30.8 & 25.1 & 83.6 \\
\hline Gelsemium sempervirens & 16.6 & 12.8 & 14.0 & 43.4 \\
\hline Smilax rotundifolia & 5.6 & 5.1 & 6.3 & 17.0 \\
\hline Vitis riparia & 5.6 & 2.6 & 3.0 & 11.2 \\
\hline Smilax glauca & 5.6 & 2.6 & 3.0 & 11.2 \\
\hline Berchemia scandens & 5.6 & 2.6 & 3.0 & 11.2 \\
\hline \multirow[t]{2}{*}{ Bignonia capreolata } & 5.6 & 2.6 & 0.7 & 8.9 \\
\hline & 100.0 & 100.0 & 100.0 & 300.0 \\
\hline \multicolumn{5}{|l|}{ Herbs and Woody Seedlings } \\
\hline Arundinaria gigantea & 12.9 & -- & 27.8 & 40.7 \\
\hline Carex sp. & 10.9 & - & 8.9 & 19.8 \\
\hline Chasmanthium sessiliflorum & 7.6 & -- & 7.2 & 14.8 \\
\hline Vaccinium arboreum & 5.4 & -- & 9.0 & 14.4 \\
\hline Bignonia capreolata & 8.7 & - & 4.7 & 13.4 \\
\hline Panicum sp. & 7.6 & -- & 4.2 & 11.8 \\
\hline Crataegus marshallii & 4.3 & - & 5.5 & 9.8 \\
\hline Smilax glauca & 5.4 & -- & 3.0 & 8.4 \\
\hline Toxicodendron radicans & 5.4 & - & 3.0 & 8.4 \\
\hline Mitchella repens & 3.3 & - & 4.9 & 8.2 \\
\hline Quercus nigra & 4.3 & -- & 2.4 & 6.7 \\
\hline Ulmus alata & 3.3 & - & 1.8 & 5.1 \\
\hline Smilax bona-nox & 3.3 & -- & 1.8 & 5.1 \\
\hline Smilax rotundifolia & 1.1 & -- & 3.7 & 4.8 \\
\hline Ilex opaca & 1.1 & - & 3.7 & 4.8 \\
\hline Carpinus caroliniana & 2.2 & - & 1.2 & 3.4 \\
\hline Acer rubrum & 2.2 & -- & 1.2 & 3.4 \\
\hline Vitis riparia & 1.1 & -- & 0.6 & 1.7 \\
\hline Vaccinium elliottii & 1.1 & - & 0.6 & 1.7 \\
\hline U1mus americana & 1.1 & - & 0.6 & 1.7 \\
\hline Solanum carolinense & 1.1 & -- & 0.6 & 1.7 \\
\hline Sebastiania fruticosa & 1.1 & -- & 0.6 & 1.7 \\
\hline Sabal minor & 1.1 & -- & 0.6 & 1.7 \\
\hline Quercus Phellos & 1.1 & - & 0.6 & 1.7 \\
\hline Quercus michauxii & 1.1 & - & 0.6 & 1.7 \\
\hline Malus coronaria & 1.1 & $\cdots$ & 0.6 & 1.7 \\
\hline \multirow[t]{2}{*}{ Cornus foemina } & 1.1 & -- & 0.6 & 1.7 \\
\hline & 100.0 & & $\overline{100.0}$ & 200.0 \\
\hline
\end{tabular}


Table D-14

Importance Values for Species Occurring at Site 14. Arranged by Zone and Vegetation Layer

Species

$\begin{array}{cccc}\text { Percent } & \text { Percent } & \text { Percent } & \\ \text { Relative } & \text { Relative } & \text { Relative } & \text { Importance } \\ \text { Frequency } & \text { Density } & \text { Dominance } & \text { Value } \\ & & \end{array}$

Zone 2

Trees

Planera aquatica

Nyssa aquatica

Fraxinus caroliniana

Taxodium distichum

Forestiera acuminata

Carya aquatica

Saplings and Shrubs

Forestiera acuminata

Fraxinus caroliniana

Planera aquatica

Nyssa aquatica

Woody Vines

Brunnichia cirrhosa

Ampelopsis arborea

Trachelospermum difforme

$V$ itis rotundifolia

$V$ itis riparia

Herbs and Woody Seedlings

Leersia lenticularis

Brunnichia cirrhosa

Ampelopsis arborea

Boehmeria cylindrica

Pluchea camphorata

Taxodium distichum

Planera aquatica

Trachelospermum difforme

Panicum sp.

Nyssa aquatica

Commelina diffusa

Ulmus americana

Toxicodendron radicans

Carex sp.

Vitis riparia

Ulmus alata

Panicum rigidulum

$\begin{array}{r}31.6 \\ 15.8 \\ 26.3 \\ 10.5 \\ 10.5 \\ 5.3 \\ \hline 100.0\end{array}$

$\begin{array}{r}51.0 \\ 9.8 \\ 25.5 \\ 7.8 \\ 3.9 \\ 2.0 \\ \hline 100.0\end{array}$

42.8

28.6

14.3

14.3

100.0

\begin{tabular}{rr}
47.0 & 73.9 \\
29.4 & 18.7 \\
11.8 & 4.7 \\
5.9 & 1.8 \\
5.9 & 0.9 \\
\hline 100.0 & 100.0
\end{tabular}

34.0

34.1

7.8

20.6

0.4

$\frac{3.1}{100.0}$

69.1

20.5

5.2

5.2

100.0

85.4

8.9

1.7

3.6

$\frac{0.4}{100.0}$

23.5

12.8

19.2

9.4

5.2

4.2

3.4

2.5

2.5

2.5

2.5

1.7

1.7

1.7

0.8

0.8

0.8
116.6

59.7

59.6

38.9

14.8

10.4

300.0

175.0

75.4

24.8

$\frac{24.8}{300.0}$

206.3

57.0

18.2

11.3

$\frac{7.2}{300.0}$

2.4

1.1

1.1

1.1

37.4

30.1

27.3

22.1

12.2

9.9

8.0

5.9

5.9

5.9

5.9

4.1

4.1

4.1

1.9

1.9

1.9 
Table D-14--continued

\begin{tabular}{|c|c|c|c|c|}
\hline Species & 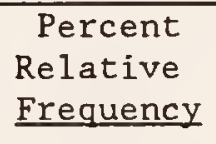 & $\begin{array}{r}\text { Percent } \\
\text { Relative } \\
\text { Density } \\
\end{array}$ & $\begin{array}{c}\text { Percent } \\
\text { Relative } \\
\text { Dominance }\end{array}$ & $\begin{array}{c}\text { Importance } \\
\text { Value }\end{array}$ \\
\hline Ilex decidua & 1.1 & - & 0.8 & 1.9 \\
\hline Forestiera acuminata & 1.1 & -- & 0.8 & 1.9 \\
\hline Eupatorium serotinum & 1.1 & - & 0.8 & 1.9 \\
\hline Ageratina altissima & 1.1 & -- & 0.8 & 1.9 \\
\hline Carya aquatica & 1.1 & -- & 0.8 & 1.9 \\
\hline \multirow[t]{3}{*}{ Bidens discoidea } & 1.1 & - & 0.8 & 1.9 \\
\hline & 100.0 & & 100.0 & 200.0 \\
\hline & \multicolumn{2}{|c|}{ Zone 5} & & \\
\hline \multicolumn{5}{|l|}{ Trees } \\
\hline Carpinus caroliniana & 22.0 & 36.9 & 10.0 & 68.9 \\
\hline Quercus phellos & 15.6 & 11.1 & 28.7 & 55.4 \\
\hline Liquidambar styraciflua & 15.6 & 18.5 & 10.8 & 44.9 \\
\hline Quercus nigra & 6.2 & 5.6 & 12.3 & 24.1 \\
\hline Fraxinus pennsylvanica & 9.5 & 7.4 & 1.6 & 18.5 \\
\hline Quercus michauxii & 6.2 & 3.7 & 8.5 & 18.4 \\
\hline Pinus glabra & 3.1 & 3.7 & 11.2 & 18.0 \\
\hline Nyssa sylvatica & 6.2 & 3.7 & 7.7 & 17.6 \\
\hline Ulmus americana & 6.3 & 3.7 & 7.0 & 17.0 \\
\hline Quercus 1yrata & 3.1 & 1.9 & 1.0 & 6.0 \\
\hline Ulmus alata & 3.1 & 1.9 & 0.6 & 5.6 \\
\hline \multirow[t]{2}{*}{ Pinus elliottii } & 3.1 & 1.9 & 0.6 & 5.6 \\
\hline & $\overline{100.0}$ & $\overline{100.0}$ & $\overline{100.0}$ & 300.0 \\
\hline \multicolumn{5}{|l|}{$\underline{\text { Saplings and Shrubs }}$} \\
\hline Carpinus caroliniana & 20.5 & 25.8 & 28.3 & 74.6 \\
\hline Ilex decidua & 12.7 & 19.2 & 19.2 & 51.1 \\
\hline Ulmus alata & 12.7 & 19.2 & 17.0 & 48.9 \\
\hline Ulmus rubra & 10.3 & 9.0 & 9.2 & 28.5 \\
\hline Fraxinus pennsylvanica & 10.3 & 6.7 & 7.5 & 24.5 \\
\hline Quercus michauxii & 10.3 & 6.7 & 6.5 & 23.5 \\
\hline Liquidambar styraciflua & 10.3 & 5.6 & 6.1 & 22.0 \\
\hline Arundinaria gigantea & 5.1 & 4.5 & 2.5 & 12.1 \\
\hline Quercus phellos & 2.6 & 1.1 & 1.4 & 5.1 \\
\hline Quercus nigra & 2.6 & 1.1 & 1.4 & 5.1 \\
\hline \multirow[t]{2}{*}{ Cornus drummondii } & 2.6 & 1.1 & 0.9 & 4.6 \\
\hline & $\overline{100.0}$ & $\overline{100.0}$ & $\overline{100.0}$ & $\overline{300.0}$ \\
\hline \multicolumn{5}{|l|}{ Woody Vines } \\
\hline Vitis rotundifolia & 42.9 & 54.3 & 58.6 & 155.8 \\
\hline Toxicodendron radicans & 19.0 & 23.9 & 19.5 & 62.4 \\
\hline Vitis riparia & 19.0 & 10.9 & 10.0 & 39.9 \\
\hline Campsis radicans & 14.3 & 8.7 & 9.3 & 32.3 \\
\hline \multirow{2}{*}{ Smilax rotundifolia } & 4.8 & 2.2 & 2.6 & 9.6 \\
\hline & $\overline{100.0}$ & 100.0 & $\overline{100.0}$ & 300.0 \\
\hline
\end{tabular}


Table D-14--continued

Species

$\begin{array}{cccc}\text { Percent } & \text { Percent } & \text { Percent } & \\ \text { Relative } & \begin{array}{c}\text { Relative } \\ \text { Relative }\end{array} & \begin{array}{l}\text { Importance } \\ \text { Value }\end{array} \\ \text { Frequency } & \text { Density } & \text { Dominance } & \text { Valong }\end{array}$

Herbs and Woody Seedlings

Carex sp.

Smilax rotundifolia

Bignonia capreolata

Quercus nigra

Dichanthelium commutatum

Arundinaria gigantea

Sabal minor

Quercus phellos

Panicum sp.

Rubus trivialis

Toxicodendron radicans

Dicliptera brachiata

Viola missouriensis

Aster sp.

Aristolochia serpentaria

Vitis rotundifolia

Vaccinium elliottii

Smilax glauca

Smilax bona-nox

Planera aquatica

Morus rubra

Carya aquatica

Brunnichia cirrhosa

Botrychium biternatum

Berchemia scandens

Ampelopsis arborea

\begin{tabular}{rrrr}
17.6 & - & 24.1 & 41.7 \\
8.8 & -- & 12.0 & 20.8 \\
11.4 & -- & 8.8 & 20.2 \\
6.3 & -- & 5.0 & 11.3 \\
6.3 & -- & 5.0 & 11.3 \\
2.5 & -- & 7.1 & 9.6 \\
5.0 & -- & 4.0 & 9.0 \\
5.0 & -- & 4.0 & 9.0 \\
5.0 & -- & 4.0 & 9.0 \\
3.8 & - & 3.0 & 6.8 \\
3.8 & -- & 3.0 & 6.8 \\
3.8 & -- & 3.0 & 6.8 \\
2.5 & -- & 2.0 & 4.5 \\
2.5 & -- & 2.0 & 4.5 \\
2.5 & -- & 2.0 & 4.5 \\
1.2 & -- & 1.0 & 2.2 \\
1.2 & -- & 1.0 & 2.2 \\
1.2 & -- & 1.0 & 2.2 \\
1.2 & -- & 1.0 & 2.2 \\
1.2 & -- & 1.0 & 2.2 \\
1.2 & -- & 1.0 & 2.2 \\
1.2 & -- & 1.0 & 2.2 \\
1.2 & -- & 1.0 & 2.2 \\
1.2 & -- & 1.0 & 2.2 \\
1.2 & -- & 1.0 & 2.2 \\
1.2 & - & 1.0 & 2.2 \\
\hline 100.0 & & 100.0 & 200.0
\end{tabular}

Zone 6

\section{Trees}

Juniperus virginiana

Carya tomentosa

Quercus stellata

Ulmus alata

Quercus nigra

Pinus glabra

Pinus taeda

Quercus falcata var. pagodifolia

Liquidambar styraciflua

Nyssa sylvatica

Quercus phellos
24.4

15.2

12.1

9.1

9.1

3.0

3.0

6.1

3.0

3.0

3.0
23.5

23.5

14.9

6.4

6.4

4.3

2.1

4.2

4.2

2.1

2.1
34.4

14.7

14.9

4.3

1.5

8.8

10.4

1.4

4.0

3.6

0.9
82.3

53.4

41.9

19.8

17.0

16.1

15.5

11.7

11.2

6.0

6.0 
Table D-14--continued

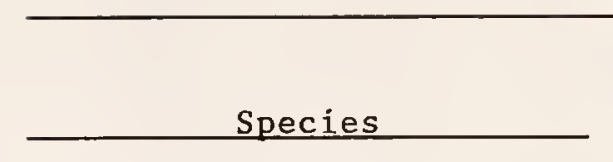

$\begin{array}{crcr}\begin{array}{c}\text { Percent } \\ \text { Relative } \\ \text { Frequency }\end{array} & \begin{array}{c}\text { Percent } \\ \text { Relative } \\ \text { Density }\end{array} & \begin{array}{c}\text { Percent } \\ \text { Relative } \\ \text { Dominance }\end{array} & \begin{array}{c}\text { Importance } \\ \text { Dalue }\end{array} \\ 3.0 & 2.1 & 0.4 & 5.5 \\ 3.0 & 2.1 & 0.4 & 5.5 \\ \frac{3.0}{100.0} & \frac{2.1}{100.0} & \frac{0.3}{100.0} & \frac{5.4}{300.0}\end{array}$

$\underline{\text { Saplings and Shrubs }}$

Vaccinium arboreum

Ilex decidua

Arundinaria gigantea

Juniperus virginiana

Ulmus alata

Quercus falcata var. pagodifolia

Cornus drummondii

Fraxinus americana

Cercis canadensis

Carya tomentosa

Asimina parviflora

Quercus stellata

Quercus nigra

Quercus michauxii

Vaccinium elliottii

Quercus phellos

Prunus umbellata

Malus angustifolia

Carpinus caroliniana

Asimina triloba

\begin{tabular}{rrrr}
11.4 & 42.4 & 43.1 & 96.9 \\
12.8 & 8.8 & 10.2 & 31.8 \\
5.7 & 15.6 & 9.3 & 30.6 \\
8.6 & 5.6 & 7.3 & 21.5 \\
8.6 & 5.6 & 6.2 & 20.4 \\
8.6 & 4.8 & 6.4 & 19.8 \\
& & & \\
8.6 & 4.4 & 4.1 & 17.1 \\
5.7 & 2.4 & 2.4 & 10.5 \\
5.7 & 2.4 & 1.8 & 9.9 \\
2.9 & 1.6 & 2.4 & 6.9 \\
4.3 & 1.2 & 0.9 & 6.4 \\
2.9 & 0.8 & 1.2 & 4.9 \\
2.9 & 0.8 & 1.1 & 4.8 \\
2.9 & 0.8 & 0.8 & 4.5 \\
1.4 & 0.8 & 0.3 & 2.5 \\
1.4 & 0.4 & 0.6 & 2.4 \\
1.4 & 0.4 & 0.6 & 2.4 \\
1.4 & 0.4 & 0.6 & 2.4 \\
1.4 & 0.4 & 0.4 & 2.2 \\
1.4 & 0.4 & 0.3 & 2.1 \\
\hline 100.0 & 100.0 & 100.0 & 300.0
\end{tabular}

Woody Vines

Vitis rotundifolia

Toxicodendron radicans

25.0

28.0

47.6

100.6

20.0

25.0

22.4

67.4

25.0

18.8

Bignonia capreolata

Gelsemium sempervirens

10.0

9.4

8.5

7.2

52.3

5.0

6.3

10.5

26.6

5.0

6.3

1.9

21.8

5.0

3.1

Berchemia scandens

$\frac{5.0}{100.0}$

$\frac{3.1}{100.0}$

1.3

13.2

9.4

0.6

100.0

$\frac{8.7}{300.0}$

Herbs and Woody Seedlings

Chasmanthium sessiliflorum

Bignonia capreolata

Quercus falcata var.

13.8

28.5

42.3

17.2

13.86

30.8

6.0

9.4

15.4

pagodifolia

Arundinaria gigantea

5.2

8.9

14.1

Aster sp.

7.8

5.4

13.2 
Table D-14--continued

\begin{tabular}{|c|c|c|c|c|}
\hline Species & $\begin{array}{l}\text { Percent } \\
\text { Relative } \\
\text { Frequency }\end{array}$ & $\begin{array}{r}\text { Percent } \\
\text { Relative } \\
\text { Density } \\
\end{array}$ & $\begin{array}{l}\text { Percent } \\
\text { Relative } \\
\text { Dominance }\end{array}$ & $\begin{array}{c}\text { Importance } \\
\text { Value }\end{array}$ \\
\hline Carex sp. & 6.9 & - & 4.3 & 11.2 \\
\hline Quercus nigra & 6.0 & - & 3.8 & 9.8 \\
\hline Quercus phellos & 5.2 & -- & 3.3 & 8.5 \\
\hline Panicum sp. & 5.2 & - & 3.3 & 8.5 \\
\hline Ulmus alata & 3.4 & - & 2.2 & 5.6 \\
\hline Sabal minor & 3.4 & - & 2.2 & 5.6 \\
\hline Vaccinium arboreum & 1.7 & $\cdots$ & 3.9 & 5.6 \\
\hline Rubus trivialis & 1.7 & - & 1.1 & 2.8 \\
\hline Robinia nana & 1.7 & - & 1.1 & 2.8 \\
\hline Oxalis stricta & 1.7 & - & 1.1 & 2.8 \\
\hline Mitchella repens & 1.7 & - & 1.1 & 2.8 \\
\hline Conoclinium coelestinum & 1.7 & - & 1.1 & 2.8 \\
\hline Dicliptera brachiata & 1.7 & - & 1.1 & 2.8 \\
\hline Cocculus carolinus & 1.7 & - & 1.1 & 2.8 \\
\hline Smilax glauca & 0.9 & - - & 0.5 & 1.4 \\
\hline Rubus argutus & 0.9 & - & 0.5 & 1.4 \\
\hline Pinus glabra & 0.9 & - & 0.5 & 1.4 \\
\hline Juniperus virginiana & 0.9 & - & 0.5 & 1.4 \\
\hline Gelsemium sempervirens & 0.9 & - & 0.5 & 1.4 \\
\hline Castanea pumila & 0.9 & - & 0.5 & 1.4 \\
\hline \multirow[t]{2}{*}{ Berchemia scandens } & 0.9 & - & 0.5 & 1.4 \\
\hline & 100.0 & & 100.0 & 200.0 \\
\hline
\end{tabular}


Table D-15

Importance Values for Species Occurring at Site 15. Arranged by Zone and Vegetation Layer

\begin{tabular}{|c|c|c|c|c|}
\hline Species & $\begin{array}{c}\text { Percent } \\
\text { Relative } \\
\text { Frequency }\end{array}$ & $\begin{array}{r}\text { Percent } \\
\text { Relative } \\
\text { Density } \\
\end{array}$ & $\begin{array}{c}\text { Percent } \\
\text { Relative } \\
\text { Dominance } \\
\end{array}$ & $\begin{array}{c}\text { Importance } \\
\text { Value } \\
\end{array}$ \\
\hline & Zone 2 & & & \\
\hline \multicolumn{5}{|l|}{ Trees } \\
\hline Taxodium distichum & 24.4 & 42.7 & 41.1 & 108.2 \\
\hline Quercus Iyrata & 14.6 & 6.9 & 35.8 & 57.3 \\
\hline Fraxinus caroliniana & 22.0 & 25.6 & 7.0 & 54.6 \\
\hline Planera aquatica & 19.5 & 12.8 & 10.1 & 42.4 \\
\hline Nyssa aquatica & 14.6 & 10.3 & 4.4 & 29.3 \\
\hline \multirow[t]{2}{*}{ Nyssa biflora } & 4.9 & 1.7 & $\underline{1.6}$ & 8.2 \\
\hline & $\overline{100.0}$ & $1 \overline{00.0}$ & 100.0 & 300.0 \\
\hline \multicolumn{5}{|l|}{ Saplings and Shrubs } \\
\hline$\overline{\text { Fraxinus caroliniana }}$ & 45.4 & 60.9 & 60.4 & 166.7 \\
\hline Styrax americana & 31.8 & 33.3 & 35.0 & 100.1 \\
\hline Itea virginica & 9.1 & 4.2 & 2.6 & 15.9 \\
\hline Planera aquatica & 9.1 & 1.1 & 1.5 & 11.7 \\
\hline \multirow[t]{2}{*}{ Taxodium distichum } & 4.6 & 0.5 & 0.5 & 5.6 \\
\hline & 100.0 & $\overline{100.0}$ & $\overline{100.0}$ & $\overline{300.0}$ \\
\hline \multicolumn{5}{|l|}{ Woody Vines } \\
\hline Toxicodendron radicans & 25.0 & 58.8 & 51.6 & 135.4 \\
\hline Smilax walteri & 25.0 & 17.9 & 24.6 & 67.5 \\
\hline Campsis radicans & 12.5 & 17.9 & 21.1 & 51.5 \\
\hline Smilax hispida & 25.0 & 3.6 & 1.8 & 30.4 \\
\hline \multirow[t]{2}{*}{ Smilax laurifolia } & 12.5 & 1.8 & 0.9 & 15.2 \\
\hline & 100.0 & 100.0 & 100.0 & 300.0 \\
\hline \multicolumn{5}{|l|}{ Herbs and Woody Seedlings } \\
\hline Boehmeria cylindrica & 11.3 & -- & 17.8 & 29.1 \\
\hline Vitis palmata & 13.2 & - & 15.6 & 28.8 \\
\hline Smilax hispida & 16.9 & -- & 8.3 & 25.2 \\
\hline Justicia ovata & 5.7 & - & 13.3 & 19.0 \\
\hline Aster simplex & 7.5 & -- & 10.8 & 18.3 \\
\hline Toxicodendron radicans & 3.8 & - & 9.6 & 13.4 \\
\hline Hypoxis leptocarpa & 3.8 & - & 9.6 & 13.4 \\
\hline Fraxinus caroliniana & 7.5 & - & 5.4 & 12.9 \\
\hline Leersia virginica & 9.4 & - & 3.0 & 12.4 \\
\hline Planera aquatica & 5.7 & -- & 1.8 & 7.5 \\
\hline Campsis radicans & 3.8 & - & 1.2 & 5.0 \\
\hline Acer rubrum & 3.8 & $\cdots$ & 1.2 & 5.0 \\
\hline Vitis rotundifolia & 1.9 & -- & 0.6 & 2.5 \\
\hline Styrax americana & 1.9 & - & 0.6 & 2.5 \\
\hline
\end{tabular}


Table D-15--continued

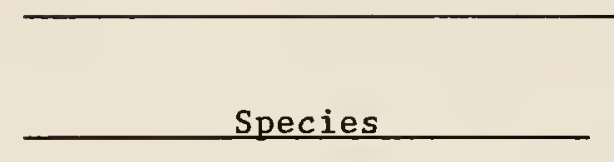

\begin{tabular}{|c|c|c|c|}
\hline $\begin{array}{l}\text { Percent } \\
\text { Relative } \\
\text { Frequency }\end{array}$ & $\begin{array}{r}\text { Percent } \\
\text { Relative } \\
\text { Density }\end{array}$ & $\begin{array}{c}\text { Percent } \\
\text { Relative } \\
\text { Dominance }\end{array}$ & $\begin{array}{c}\text { Importance } \\
\text { Value }\end{array}$ \\
\hline 1.9 & - - & 0.6 & 2.5 \\
\hline$\frac{1.9}{100}$ & $\ldots$ & $\frac{0.6}{100}$ & $\frac{2.5}{100}$ \\
\hline
\end{tabular}

Ilex decidua

Crataegus viridis

\section{Zone 3}

\section{Trees}

Quercus laurifolia

Liquidambar styraciflua

Ilex decidua

Quercus phellos

Quercus lyrata

Carpinus caroliniana

Quercus nigra

Taxodium distichum

Ulmus americana

Acer rubrum

Carya aquatica

Saplings and Shrubs

Ilex decidua
Quercus laurifolia
Styrax americana
Vaccinium elliottii
Sebastiania fruticosa
Acer rubrum
Crataegus viridis
Liquidambar styracifl
Nyssa aquatica
Viburnum dentatum
Ulmus americana
Quercus lyrata
Crataegus marshallii
Fraxinus caroliniana
Carpinus caroliniana

Woody Vines

Toxicodendron radicans

Smilax walteri

Bignonia capreolata

Campsis radicans

Smilax hispida

Trachelospermum difforme

Vitis palmata

\begin{tabular}{rr}
21.2 & 26.0 \\
24.3 & 18.0 \\
18.2 & 30.0 \\
9.1 & 6.0 \\
6.1 & 6.0 \\
6.1 & 4.0 \\
3.0 & 2.0 \\
3.0 & 2.0 \\
3.0 & 2.0 \\
3.0 & 2.0 \\
3.0 & 2.0 \\
\hline 100.0 & 100.0
\end{tabular}

35.5

23.2

2.6

27.8

1.2

0.8

5.5

2.4

0.6

0.2

$\frac{0.2}{100.0}$

82.7

65.5

50.8

42.0

13.3

10.9

10.5

7.4

5.6

5.2

$\frac{5.2}{300.0}$

\begin{tabular}{rrrr}
21.7 & 52.5 & 58.7 & 132.9 \\
15.2 & 7.9 & 11.7 & 34.8 \\
10.9 & 10.1 & 6.0 & 27.0 \\
10.9 & 7.4 & 4.9 & 23.2 \\
6.5 & 6.5 & 3.7 & 16.7 \\
8.7 & 3.7 & 3.0 & 15.4 \\
4.3 & 3.3 & 3.6 & 11.2 \\
4.3 & 2.8 & 3.9 & 11.0 \\
4.3 & 1.9 & 2.1 & 8.3 \\
2.2 & 1.4 & 0.9 & 4.5 \\
2.2 & 0.5 & 0.5 & 3.2 \\
2.2 & 0.5 & 0.3 & 3.0 \\
2.2 & 0.5 & 0.3 & 3.0 \\
2.2 & 0.5 & 0.2 & 2.9 \\
2.2 & 0.5 & 0.2 & 2.9 \\
\hline 100.0 & 100.0 & 100.0 & 300.0
\end{tabular}

30.1

83.0

93.5

206.6

3.5

34.9

16.7

8.1

1.1

21.9

3.0

1.0

17.4

6.6

0.1

7.1

0.3

4.6

0.3

3.8 
Table D-15--continued

\begin{tabular}{|c|c|c|c|c|}
\hline Species & $\begin{array}{c}\text { Percent } \\
\text { Relative } \\
\text { Frequency }\end{array}$ & $\begin{array}{r}\text { Percent } \\
\text { Relative } \\
\text { Density } \\
\end{array}$ & 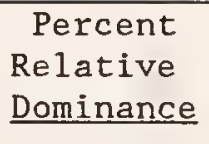 & $\begin{array}{c}\text { Importance } \\
\text { Value } \\
\end{array}$ \\
\hline Vitis rotundifolia & $\frac{3.3}{100.0}$ & $\frac{0.2}{100.0}$ & $\frac{0.2}{100.0}$ & $\frac{3.7}{300.0}$ \\
\hline \multicolumn{5}{|l|}{ Herbs and Woody Seedlings } \\
\hline Toxicodendron radicans & 12.8 & -- & 33.2 & 46.0 \\
\hline Vitis palmata & 12.8 & - & 17.7 & 30.5 \\
\hline Smilax hispida & 13.4 & -- & 13.2 & 26.6 \\
\hline Hypoxis leptocarpa & 8.5 & - & 8.9 & 17.4 \\
\hline Camps is radicans & 6.3 & - & 4.5 & 10.8 \\
\hline Sebastiania fruticosa & 4.9 & - & 4.7 & 9.6 \\
\hline Dichanthelium commutatum & 3.5 & - & 4.3 & 7.8 \\
\hline Carex sp. & 4.9 & -- & 1.4 & 6.3 \\
\hline Aster simplex & 4.2 & - & 1.2 & 5.4 \\
\hline Bignonia capreolata & 4.2 & -- & 0.7 & 4.9 \\
\hline Justicia ovata & 2.1 & - & 1.5 & 3.6 \\
\hline Fraxinus caroliniana & 2.1 & - & 1.5 & 3.6 \\
\hline Acer rubrum & 2.8 & -- & 0.5 & 3.3 \\
\hline Mikania scandens & 2.1 & - & 0.9 & 3.0 \\
\hline Crataegus viridis & 2.1 & -- & 0.9 & 3.0 \\
\hline Trachelospermum difforme & 1.4 & -- & 1.4 & 2.8 \\
\hline Unknown & 1.4 & - & 0.8 & 2.2 \\
\hline Boehmeria cylindrica & 1.4 & -- & 0.8 & 2.2 \\
\hline Vitis rotundifolia & 1.4 & -- & 0.2 & 1.6 \\
\hline Planera aquatica & 1.4 & -- & 0.2 & 1.6 \\
\hline Ilex decidua & 1.4 & -- & 0.2 & 1.6 \\
\hline Styrax americana & 0.7 & - & 0.1 & 0.8 \\
\hline Vaccinium elliottii & 0.7 & -- & 0.1 & 0.8 \\
\hline Taxodium distichum & 0.7 & - & 0.1 & 0.8 \\
\hline Sebatia calycina & 0.7 & - & 0.1 & 0.8 \\
\hline Quercus nigra & 0.7 & -- & 0.1 & 0.8 \\
\hline Liquidambar styraciflua & 0.7 & - & 0.1 & 0.8 \\
\hline \multirow[t]{3}{*}{ Ampelops is arborea } & 0.7 & -- & 0.1 & 0.8 \\
\hline & 100.0 & & 100.0 & 200.0 \\
\hline & Zone 6 & & & \\
\hline \multicolumn{5}{|l|}{ Trees } \\
\hline Quercus stellata & 25.1 & 26.9 & 28.9 & 80.9 \\
\hline Quercus falcata & 15.6 & 20.6 & 34.6 & 70.8 \\
\hline Carya tomentosa & 18.8 & 25.4 & 14.9 & 59.1 \\
\hline Quercus nigra & 9.4 & 7.9 & 8.5 & 25.8 \\
\hline Cornus florida & 9.4 & 4.8 & 2.5 & 16.7 \\
\hline Quercus laurifolia & 6.2 & 4.8 & 5.5 & 16.5 \\
\hline Liquidambar styraciflua & 6.2 & 4.8 & 3.6 & 14.6 \\
\hline
\end{tabular}


Table D-15--continued

Species

\section{Percent}

Relative

Frequency

Pinus echinata

Vaccinium arboreum

Saplings and Shrubs

Carya tomentosa
Vaccinium arboreum
Viburnum rufidulum
Quercus falcata
Quercus stellata
Sassafras albidum
Cornus florida
Liquidambar styracifl
Quercus nigra
Crataegus flava
Prunus umbellata
Chionanthus virginicu
Vaccinium elliottii
Pinus taeda
Quercus laurifolia
Morus rubra
Hamamelis virginiana
Carpinus caroliniana
Vaccinium corymbosum
Quercus marilandica
Prunus serotina
Ilex decidua
Diospyros virginiana

Woody Vines

Vitis rotundifolia

$V$ itis aestivalis

Gelsemium sempervirens

Lonicera sempervirens

Herbs and Woody Seedlings

Toxicodendron radicans

$V$ itis rotundifolia

Gelsemium sempervirens

Quercus stellata

Quercus nigra

Aristolochia serpentaria

Vaccinium arboreum

Aristida sp.

Viburnum rufidulum

$\begin{array}{rrrr}6.2 & 3.2 & 1.1 & 10.5 \\ 3.1 & 1.6 & 0.4 & \frac{5.1}{300.0}\end{array}$

\begin{tabular}{rrrr}
13.6 & 24.2 & 29.5 & 67.3 \\
9.5 & 19.1 & 19.1 & 47.7 \\
4.0 & 12.5 & 10.8 & 27.3 \\
9.6 & 8.2 & 7.3 & 25.1 \\
9.6 & 6.9 & 6.8 & 23.3 \\
6.8 & 4.7 & 4.3 & 15.8 \\
6.8 & 4.3 & 4.6 & 15.7 \\
5.4 & 4.3 & 3.8 & 13.5 \\
6.8 & 3.4 & 2.6 & 12.8 \\
5.4 & 2.2 & 1.5 & 9.1 \\
4.1 & 2.2 & 1.9 & 8.2 \\
2.7 & 2.2 & 2.5 & 7.4 \\
2.7 & 1.3 & 0.9 & 4.9 \\
1.3 & 0.9 & 0.6 & 2.8 \\
1.3 & 0.4 & 0.8 & 2.5 \\
1.3 & 0.4 & 0.5 & 2.2 \\
1.3 & 0.4 & 0.5 & 2.2 \\
1.3 & 0.4 & 0.5 & 2.2 \\
1.3 & 0.4 & 0.3 & 2.0 \\
1.3 & 0.4 & 0.3 & 2.0 \\
1.3 & 0.4 & 0.3 & 2.0 \\
1.3 & 0.4 & 0.3 & 2.0 \\
1.3 & 0.4 & 0.3 & 2.0 \\
\hline 100.0 & 100.0 & 100.0 & 300.0
\end{tabular}

\begin{tabular}{rrrr}
38.4 & 56.7 & 58.4 & 153.5 \\
30.8 & 26.7 & 36.6 & 94.1 \\
23.1 & 13.3 & 4.0 & 40.4 \\
7.7 & 3.3 & 1.0 & $\frac{12.0}{300.0}$ \\
\hline 100.0 & 100.0 & 100.0 &
\end{tabular}

$\begin{array}{rrrr}13.9 & -- & 25.4 & 39.3 \\ 9.3 & -- & 20.9 & 30.2 \\ 9.3 & -- & 13.6 & 22.9 \\ 8.1 & -- & 8.3 & 16.4 \\ 7.1 & -- & 8.0 & 15.1 \\ 7.1 & -- & 1.9 & 9.0 \\ 4.7 & - & 2.9 & 7.6 \\ 4.7 & -- & 1.3 & 6.0 \\ 2.4 & -- & 2.3 & 4.7\end{array}$


Table D-15--continued

\begin{tabular}{|c|c|c|c|c|}
\hline Species & 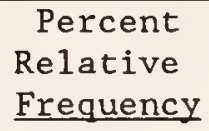 & $\begin{array}{r}\text { Percent } \\
\text { Relative } \\
\text { Density } \\
\end{array}$ & $\begin{array}{c}\text { Percent } \\
\text { Relative } \\
\text { Dominance }\end{array}$ & $\begin{array}{c}\text { Importance } \\
\text { Value } \\
\end{array}$ \\
\hline Vaccinium elliottii & 3.5 & -- & 1.0 & 4.5 \\
\hline Carex sp. & 3.5 & -- & 1.0 & 4.5 \\
\hline Sassafras albidum & 1.2 & -- & 2.0 & 3.2 \\
\hline Liquidambar styracif lua & 1.2 & - & 2.0 & 3.2 \\
\hline Cornus florida & 1.2 & - & 2.0 & 3.2 \\
\hline Carya tomentosa & 1.2 & - & 2.0 & 3.2 \\
\hline Dichanthelium commutatum & 2.4 & - & 0.6 & 3.0 \\
\hline Lespedeza sp. & 2.4 & - & 0.6 & 3.0 \\
\hline Stylisma humistrata & 2.4 & - & 0.6 & 3.0 \\
\hline Acer rubrum & 2.4 & - & 0.6 & 3.0 \\
\hline Solidago odorata & 1.2 & - & 0.3 & 1.5 \\
\hline Solidago sp. & 1.2 & - & 0.3 & 1.5 \\
\hline Smilax glauca & 1.2 & - & 0.3 & 1.5 \\
\hline Rhus copallinum & 1.2 & -- & 0.3 & 1.5 \\
\hline Prunus umbellata & 1.2 & - & 0.3 & 1.5 \\
\hline Polypodium scandens & 1.2 & - & 0.3 & 1.5 \\
\hline Ilex opaca & 1.2 & - & 0.3 & 1.5 \\
\hline Hamamelis virginiana & 1.2 & - & 0.3 & 1.5 \\
\hline Diospyros virginiana & 1.2 & $\ldots$ & 0.3 & 1.5 \\
\hline \multirow[t]{2}{*}{ Cnidoscolus stimulosus } & 1.2 & - & 0.3 & 1.5 \\
\hline & 100.0 & & 100.0 & 200.0 \\
\hline
\end{tabular}


Table D-16

Importance Values for Species Occurring at Site 16. Arranged by Zone and Vegetation Layer

Species

\begin{tabular}{cccc}
$\begin{array}{c}\text { Percent } \\
\text { Relative }\end{array}$ & $\begin{array}{c}\text { Percent } \\
\text { Relative }\end{array}$ & $\begin{array}{c}\text { Percent } \\
\text { Relative }\end{array}$ & Importance \\
Frequency & Density & Dominance & Value \\
\cline { 2 - 5 } & &
\end{tabular}

Zone 2

Trees

Fraxinus caroliniana

Nyssa aquatica

Planera aquatica

Taxodium distichum

Salix nigra

Betula nigra

Quercus laurifolia

Saplings and Shrubs

Fraxinus caroliniana

Planera aquatica

Salix nigra

Cephalanthus occidentalis

Crataegus aestivalis

Gleditsia aquatica

Itea virginica

Woody Vines

Smilax walteri

Herbs and Woody Seedlings

Planera aquatica

Taxodium distichum

Fraxinus caroliniana

Vitis sp.

Panicum rigidulum

$$
\begin{array}{r}
25.8 \\
22.6 \\
29.1 \\
9.7 \\
6.4 \\
3.2 \\
3.2 \\
\hline 100.0
\end{array}
$$

$$
\begin{array}{r}
37.6 \\
25.0 \\
8.3 \\
8.3 \\
8.3 \\
8.3 \\
4.2 \\
\hline 100.0
\end{array}
$$

100.0

57.2

14.3

14.3

7.1

$\frac{7.1}{100.0}$

Zone 3

\section{Trees}

Fraxinus caroliniana

Quercus laurifolia

Quercus Iyrata

Taxodium distichum

Acer rubrum

Liquidambar styraciflua

Planera aquatica

Nyssa aquatica
20.7

24.2

10.4

10.4

6.9

6.9

3.4

3.4

$\begin{array}{r}53.6 \\ 9.6 \\ 28.0 \\ 2.4 \\ 4.8 \\ 0.8 \\ 0.8 \\ \hline 100.0\end{array}$

55.4

22.6

14.7

3.1

1.2

1. 2

$\frac{1.8}{100.0}$

100.0

-

- -

-

-

-

49.9
18.0
4.2
5.6
6.9
2.8
5.6
1.4

49.9

13.4

41.3

14.3

6.5

2.5

6.0

4.3

8.5
96.8

85.5

78.1

16.1

14.1

5.2

$\frac{4.2}{300.0}$

149.0

68.9

40.3

13.9

11.1

10.2

$\frac{6.6}{300.0}$

300.0

114.4

28.6

28.6

14.2

$\frac{14.2}{200.0}$ 
Table D-16--continued

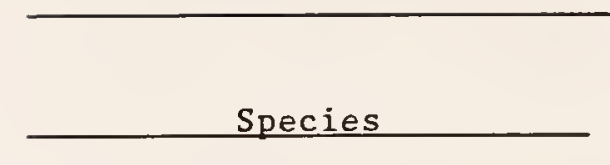

\begin{tabular}{crcr}
$\begin{array}{c}\text { Percent } \\
\text { Relative } \\
\text { Frequency }\end{array}$ & $\begin{array}{c}\text { Percent } \\
\text { Relative } \\
\text { Density }\end{array}$ & $\begin{array}{c}\text { Percent } \\
\text { Relative } \\
\text { Dominance }\end{array}$ & $\begin{array}{c}\text { Importanc } \\
\text { Dalue }\end{array}$ \\
\cline { 5 - 5 } 6.9 & 2.8 & 2.3 & \\
3.4 & 1.4 & 0.6 & 12.0 \\
3.4 & $\frac{1.4}{100.0}$ & $\frac{0.3}{100.0}$ & $\frac{5.1}{300.0}$
\end{tabular}

Saplings and Shrubs

Fraxinus caroliniana
Quercus laurifolia
Cephalanthus occidentalis
Crataegus aestivalis
Styrax americana
Taxodium distichum
Sebastiania fruticosa
Ilex decidua
Quercus lyrata
Acer rubrum
Hypericum galioides
Gleditsia aquatica
Planera aquatica
Liquidambar styraciflua

25.5

Betula nigra

Ilex decidua

Cephalanthus occidentalis

15.4

59.7

60.7

8.6

6.6

4.7

5.2

2.3

1.4

2.9

2.1

2.6

1.0

1.3

0.3

145.9

30.6

21.7

16.1

15.4

12.9

12.0

5.1

3.7

2.6

2. 2

2.6

2. 2

2.6

0.7

2.6

0.7

11.7

8.7

7.4

5.8

4.6

$\frac{2.6}{100.0}$

$\frac{0.7}{100.0}$

3.6

$\frac{3.6}{300.0}$

Woody Vines

Smilax walteri

Vitis riparia

Trachelospermum difforme

$V$ itis aestivalis

Ampelopsis arborea

$\begin{array}{r}50.0 \\ 16.7 \\ 16.7 \\ 8.3 \\ 8.3 \\ \hline 100.0\end{array}$

8.5

Herbs and Woody Seedlings

Panicum rigidulum
Smilax rotundifolia
Ampelopsis arborea
Erechtites hieracifolia
Trachelospermum difforme
Toxicodendron radicans
Quercus nigra
Planera aquatica
Carex joorii
Sebastiania fruticosa
Taxodium distichum
Quercus laurifolia
Parthenocissus quinquefolia
Vitis sp.
Quercus phellos
Liquidambar styraciflua

12.8

10.6

6.4

6.4

6.4

6.4

6.4

6.4

2.1

4.3

4.3

4.3

2.1

2.1

2.1

$\begin{array}{r}89.0 \\ 4.4 \\ 2.2 \\ 2.2 \\ 2.2 \\ \hline 100.0\end{array}$

$-\cdot$

$-\cdot$

$-$

$-\cdot$

-

-

-

- -

-

-.

-.

$-$

$\cdots$

$\cdots$

$--$

-.
44.2

10.5

4.8

7.7

2.9

2.9

2.9

2.9

2.9

5.9

1.8

1.8

1.8

1.0

1.0

1.0
233.4

22.5

20.3

11.9

$\frac{11.9}{300.0}$

52.7

23.3

15.4

14.1

9.3

9.3

9.3

9.3

9.3

8.0

6.1

6.1

6.1

3.1

3.1

3.1 
Table D-16--continued

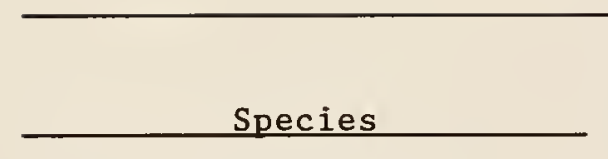

$\begin{array}{cccc}\begin{array}{c}\text { Percent } \\ \text { Relative } \\ \text { Frequency }\end{array} & \begin{array}{c}\text { Percent } \\ \text { Relative } \\ \text { Density }\end{array} & \begin{array}{c}\text { Percent } \\ \text { Relative } \\ \text { Dominance }\end{array} & \begin{array}{c}\text { Importance } \\ \text { Value }\end{array} \\ 2.1 & -- & 1.0 & 3.1 \\ 2.1 & -- & 1.0 & 3.1 \\ 2.1 & -- & 1.0 & 3.1 \\ \frac{2.1}{100.0} & -- & \frac{1.0}{100.0} & \frac{3.1}{200.0}\end{array}$

Hypericum galioides

Fraxinus caroliniana

Cephalanthus occidentalis

Acer rubrum

\section{Trees}

Quercus laurifolia

Quercus nigra

Carpinus caroliniana

Liquidambar styraciflua

Acer rubrum

Quercus lyrata

Pinus taeda

Nyssa sylvatica

Betula nigra

Ilex decidua

Saplings and Shrubs

Quercus laurifolia

Vaccinium elliottii

Styrax americana

Fraxinus caroliniana

Ilex decidua

Cornus foemina

Hypericum galioides

Carpinus caroliniana

Acer rubrum

Nyssa sylvatica

Ilex opaca

Liquidambar styraciflua

Quercus nigra

Itea virginica

Leucothoe racemosa

Sebastiania fruticosa

Sabal minor

Ulmus americana

Amorpha fruticosa

Vaccinium corymbosum

Quercus virginiana

Viburnum dentatum

Diospyros virginiana

Cephalanthus occidentalis

Viburnum obovatum

\begin{tabular}{rr}
30.0 & 38.9 \\
16.7 & 13.0 \\
6.7 & 22.2 \\
10.0 & 5.5 \\
10.0 & 5.5 \\
10.0 & 5.5 \\
3.3 & 1.9 \\
6.7 & 3.7 \\
3.3 & 1.9 \\
3.3 & 1.9 \\
\hline 100.0 & 100.0
\end{tabular}

6.8

7.8

7.8

7.8

9.0

6.8

1.1

5.6

6.8

5.6

5.6

3.4

3.4

2.3

1.1

2.3

2.3

2.3

2.3

1.1

1.1

1.1

1.1

1. 1

1.1
11.9

11.9

9.2

10.2

7.0

8.9

13.9

5.8

5.2

3.1

1.8

1.2

0.9

1.2

1.8

0.9

0.9

0.6

0.6

0.6

0.3

0.3

0.3

0.3

0.3
47.8

12.2

4.6

14.3

5.5

4.0

9. 3

1.5

0.6

$\frac{0.2}{100.0}$

17.2

8.1

10.1

8.4

10.0

10.1

7.8

7.5

6.6

3.3

1.9

1.3

1.6

0.7

1.1

0.5

0.5

0.5

0.3

0.4

0.4

0.3

0.3

0.3

0.2
116.7

41.9

33.5

29.8

21.0

19.5

14.5

11.9

5.8

$\frac{5.4}{300.0}$

35.9

27.8

27.1

26.4

26.0

25.8

22.8

18.9

18.6

12.0

9.3

5.9

5.9

4.2

4.0

3.7

3.7

3.4

3.2

2.1

1.8

1.7

1.7

1.7

1.6 
Table D-16--continued

\begin{tabular}{|c|c|c|c|c|}
\hline Species & 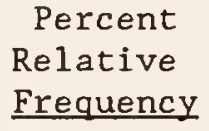 & $\begin{array}{r}\text { Percent } \\
\text { Relative } \\
\text { Density } \\
\end{array}$ & $\begin{array}{l}\text { Percent } \\
\text { Relative } \\
\text { Dominance }\end{array}$ & $\begin{array}{c}\text { Importance } \\
\text { Value }\end{array}$ \\
\hline Persea borbonia & 1.1 & 0.3 & 0.2 & 1.6 \\
\hline Taxodium distichum & 1.1 & 0.3 & 0.2 & 1.6 \\
\hline \multirow[t]{2}{*}{ Betula nigra } & 1.1 & 0.3 & 0.2 & 1.6 \\
\hline & 100.0 & 100.0 & 100.0 & 300.0 \\
\hline \multicolumn{5}{|l|}{ Woody Vines } \\
\hline Smilax walteri & 34.7 & 62.1 & 31.5 & 128.3 \\
\hline Campsis radicans & 30.4 & 19.7 & 50.3 & 100.4 \\
\hline Vitis riparia & 13.0 & 4.6 & 5.6 & 23.2 \\
\hline Ampelopsis arborea & 8.7 & 7.6 & 6.5 & 22.8 \\
\hline Vitis palmata & 3.3 & 1.5 & 4.1 & 8.9 \\
\hline Trachelospermum difforme & 3.3 & 1.5 & 1.0 & 5.8 \\
\hline Parthenocissus quinquefolia & 3.3 & 1.5 & 0.5 & 5.3 \\
\hline \multirow[t]{2}{*}{ Vitus rotundifolia } & 3.3 & 1.5 & 0.5 & 5.3 \\
\hline & $\overline{100.0}$ & 100.0 & $\overline{100.0}$ & 300.0 \\
\hline \multicolumn{5}{|l|}{ Herbs and Woody Seedlings } \\
\hline Carex louisianica & 4.6 & -- & 14.5 & 19.1 \\
\hline Sebastiania fruticosa & 9.8 & - & 7.7 & 17.5 \\
\hline Itea virginica & 8.3 & - & 8.0 & 16.3 \\
\hline Quercus laurifolia & 6.1 & - & 9.7 & 15.8 \\
\hline Carex joorii & 4.6 & - & 8.7 & 13.3 \\
\hline Vaccinium elliottii & 3.8 & - & 7.6 & 11.4 \\
\hline Smilax rotundifolia & 4.6 & - & 5.6 & 10.2 \\
\hline Hypericum galioides & 3.8 & - & 5.2 & 9.0 \\
\hline Toxicodendron radicans & 6.1 & - & 2.3 & 8.4 \\
\hline Carpinus caroliniana & 5.3 & - & 2.1 & 7.4 \\
\hline Trachelospermum difforme & 3.8 & - & 3.6 & 7.4 \\
\hline Rubus trivialis & 3.8 & - & 2.7 & 6.5 \\
\hline Mitchella repens & 3.8 & - & 2.7 & 6.5 \\
\hline Ampelopsis arborea & 3.1 & - & 3.4 & 6.5 \\
\hline Campsis radicans & 2.3 & - & 2.3 & 4.6 \\
\hline Liquidambar styraciflua & 3.1 & -- & 0.7 & 3.8 \\
\hline Hypoxis leptocarpa & 2.3 & - & 1.4 & 3.7 \\
\hline Acer rubrum & 2.3 & - & 1.4 & 3.7 \\
\hline Saururus cernuus & 2.3 & - & 2.6 & 3.4 \\
\hline Vitis rotundifolia & 0.8 & - & 1.3 & 2.8 \\
\hline Unknown & 1.5 & - & 1.3 & 2.8 \\
\hline Clematis virginiana & 1.5 & - & 1.3 & 2.8 \\
\hline Styrax americana & 0.8 & - & 1.1 & 1.9 \\
\hline Ulmus americana & 1.5 & - & 0.3 & 1.8 \\
\hline Sabal minor & 1.5 & - & 0.3 & 1.8 \\
\hline Pinus glabra & 1.5 & - & 0.3 & 1.8 \\
\hline Parthenocissus quinquefolia & 1.5 & - & 0.3 & 1.8 \\
\hline Viola floridana & 0.8 & - & 0.2 & 1.0 \\
\hline Chasmanthium sessiliflorum & 0.8 & - - & 0.2 & 1.0 \\
\hline Dichanthelium commutatum & 0.8 & - & 0.2 & 1.0 \\
\hline
\end{tabular}


Table D-16--continued

\begin{tabular}{|c|c|c|c|c|}
\hline Species & \begin{tabular}{c}
\multicolumn{1}{c}{ Percent } \\
Relative \\
Frequency \\
\end{tabular} & $\begin{array}{r}\text { Percent } \\
\text { Relative } \\
\text { Density } \\
\end{array}$ & $\begin{array}{c}\text { Percent } \\
\text { Relative } \\
\text { Dominance }\end{array}$ & $\begin{array}{c}\text { Importanc } \\
\text { Value }\end{array}$ \\
\hline Nyssa sylvatica & 0.8 & -- & 0.2 & 1.0 \\
\hline Ilex opaca & 0.8 & -- & 0.2 & 1.0 \\
\hline Crataegus aestivalis & 0.8 & - & 0.2 & 1.0 \\
\hline Cornus foemina & 0.8 & -- & 0.2 & 1.0 \\
\hline \multirow[t]{3}{*}{ Betula nigra } & 0.8 & - & 0.2 & 1.0 \\
\hline & 100.0 & & 100.0 & 200.0 \\
\hline & Zone 6 & & & \\
\hline \multicolumn{5}{|l|}{ Trees } \\
\hline Pinus taeda & 36.5 & 36.1 & 81.8 & 154.4 \\
\hline Quercus nigra & 18.2 & 22.2 & 9.8 & 50.2 \\
\hline Carya glabra & 13.6 & 13.9 & 2.8 & 30.3 \\
\hline Nyssa sylvatica & 13.6 & 13.9 & 1.9 & 29.4 \\
\hline Quercus virginiana & 9.1 & 8.3 & 2.8 & 20.2 \\
\hline Liquidambar styraciflua & 4.5 & 2.8 & 0.6 & 7.9 \\
\hline \multirow[t]{2}{*}{ Vaccinium arboreum } & 4.5 & 2.8 & 0.3 & 7.6 \\
\hline & $\overline{100.0}$ & $\overline{100.0}$ & $\overline{100.0}$ & $\overline{300.0}$ \\
\hline \multicolumn{5}{|l|}{ Saplings and Shrubs } \\
\hline Myrica cerifera & 6.7 & 25.1 & 24.7 & 56.5 \\
\hline Liquidambar styraciflua & 7.4 & 11.5 & 13.3 & 32.2 \\
\hline Quercus nigra & 7.4 & 9.4 & 10.5 & 27.3 \\
\hline Symplocos tinctoria & 8.8 & 9.3 & 8.3 & 26.4 \\
\hline Acer rubrum & 6.7 & 6.4 & 7.4 & 20.5 \\
\hline Nyssa sylvatica & 7.4 & 4.6 & 5.9 & 17.9 \\
\hline Vaccinium elliottii & 6.7 & 6.1 & 4.9 & 17.7 \\
\hline Carya glabra & 7.4 & 4.6 & 4.6 & 16.6 \\
\hline Vaccinium corymbosum & 5.1 & 5.3 & 4.1 & 14.5 \\
\hline Rhododendron canescens & 4.4 & 3.2 & 2.9 & 10.5 \\
\hline Ilex opaca & 4.4 & 2.3 & 2.7 & 9.4 \\
\hline Clethra alnifolia & 4.4 & 2.8 & 2.2 & 9.4 \\
\hline Vaccinium arboreum & 2.9 & 2.5 & 2.7 & 8.1 \\
\hline Sassafras albidum & 2.9 & 1.7 & 1.5 & 6.1 \\
\hline Quercus velutina & 2.2 & 1.0 & 1.0 & 4.2 \\
\hline Ilex glabra & 2.2 & 0.5 & 0.5 & 3.2 \\
\hline Pinus taeda & 2.2 & 0.4 & 0.3 & 2.9 \\
\hline Sebastiania fruticosa & 1.5 & 0.7 & 0.6 & 2.8 \\
\hline Prunus umbellata & 1.5 & 0.5 & 0.8 & 2.8 \\
\hline Ascyrum hypericoides & 1.5 & 0.3 & 0.2 & 2.0 \\
\hline Rhus copallinum & 1.4 & 0.4 & 0.2 & 2.0 \\
\hline Viburnum dentatum & 0.7 & 0.2 & 0.1 & 1.0 \\
\hline Quercus virginiana & 0.7 & 0.2 & 0.1 & 1.0 \\
\hline Quercus laurifolia & 0.7 & 0.2 & 0.1 & 1.0 \\
\hline Persea borbonia & 0.7 & 0.2 & 0.1 & 1.0 \\
\hline Vaccinium arboreum & 0.7 & 0.2 & 0.1 & 1.0 \\
\hline Leucothoe racemosa & 0.7 & 0.2 & 0.1 & 1.0 \\
\hline
\end{tabular}


Table D-16--continued

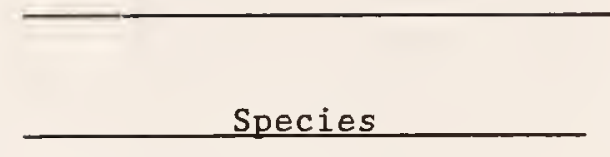

$\begin{array}{ccccc}\begin{array}{c}\text { Percent } \\ \text { Relative } \\ \text { Frequency }\end{array} & \begin{array}{c}\text { Percent } \\ \text { Relative } \\ \text { Density }\end{array} & \begin{array}{c}\text { Percent } \\ \text { Relative } \\ \text { Dominance }\end{array} & \begin{array}{c}\text { Importance } \\ \text { Value }\end{array} \\ \frac{0.7}{100.0} & \frac{0.2}{100.0} & \frac{0.1}{100.0} & & \frac{1.0}{300.0}\end{array}$

Woody Vines

Vitis rotundifolia

Gelsemium sempervirens

33.4

71.9

83.5

188.8

20.1

11.6

7.6

39.3

Smilax glauca

10.1

3.3

0.8

14.2

Smilax laurifolia

Campsis radicans

$V$ itis cinerea

Ampelopsis arborea

Vitis riparia

6.7

2.5

1.3

10.5

3.3

1.7

3. 3

3.3

8.3

3.3

2.5

3.3

1.7

Trachelospermum difforme

3. 3

0.8

1.0

6.8

0.4

5.4

0.5

4.6

3. 3

0.8

0.4

5.4

0.5

4.6

Unknown

0.8

0.2

4.3

3. 3

0.8

Parthenocissus quinquefolia

$\frac{3.3}{100.0}$

0.2

4.3

0.2

$\frac{4.3}{300.0}$

Herbs and Woody Seedlings

Vaccinium corymbosum
Clethra alnifolia
Vitis rotundifolia
Myrica cerifera
Smilax pumila
Quercus nigra
Toxicodendron radicans
Liquidambar styraciflua
Pinus glabra
Vaccinium elliottii
Carya glabra
Vaccinium arboreum
Acer rubrum
Symplocos tinctoria
Sebastiania fruticosa
Parthenocissus quinquefolia
Nyssa sylvatica
Mitchella repens
Hypericum galioides
Gaylussacia frondosa
Smilax rotundifolia
Gelsemium sempervirens
Campsis radicans
Sassafras albidum
Rhus copallinum
Ilex opaca
Callicarpa americana

7.7

8.2

6.5

5.3

6.5

6.5

5.3

4.2

4.8

3.6

3.6

2.4

1.8

2.4

2.4

2.4

1.8

1.8

0.6

0.6

1.8

1.8

1.8

1.2

1.2

1.2

1.2
16.7

9.7

8.0

9.2

7.0

5.0

5.0

5.7

3.2

4.0

2.4

2.6

3. 1

1.6

1.6

1. 6

1. 5

1.5

1.7

1. 7

0.3

0.3

0.3

0.8

0.8

0.8

0.8
24.4

17.9

14.5

14.5

13.5

11.5

10. 3

9.9

8.0

7.6

6.0

5.0

4.9

4.0

4.0

4.0

3. 3

3. 3

2.3

2. 3

2.1

2.1

2. 1

2.0

2.0

2. 0

2.0 
Table D-16--continued

\begin{tabular}{lcccc}
\hline \multicolumn{1}{c}{ Species } & $\begin{array}{c}\text { Percent } \\
\text { Relative } \\
\text { Frequency }\end{array}$ & $\begin{array}{c}\text { Percent } \\
\text { Relative } \\
\text { Density }\end{array}$ & $\begin{array}{c}\text { Percent } \\
\text { Relative } \\
\text { Dominance }\end{array}$ & $\begin{array}{c}\text { Importance } \\
\text { Value }\end{array}$ \\
\cline { 1 - 2 } Smilax glauca & 1.2 & - & 0.2 & 1.4 \\
Quercus virginiana & 1.2 & - & 0.2 & 1.4 \\
Robinia pseudoacacia & 0.6 & -- & 0.7 & 1.3 \\
Rhododendron canescens & 0.6 & -- & 0.7 & 1.3 \\
Viburnum obovatum & 0.6 & -- & 0.1 & 0.7 \\
Viola floridana & 0.6 & -- & 0.1 & 0.7 \\
Trachelospermum difforme & 0.6 & -- & 0.1 & 0.7 \\
Scleria triglomerata & 0.6 & -- & 0.1 & 0.7 \\
Quercus lyrata & 0.6 & -- & 0.1 & 0.7 \\
Prunus serotina & 0.6 & -- & 0.1 & 0.7 \\
Ascyrum hypericoides & 0.6 & -- & 0.1 & 0.7 \\
Dichondra repens & 0.6 & -- & 0.1 & 0.7 \\
Cyperus sp. & 0.6 & -- & 0.1 & 0.7 \\
Crataegus sp. & 0.6 & -- & 0.1 & 0.7 \\
Stylisma humistrata & 0.6 & -- & 0.1 & 0.7 \\
Berchemia scandens & 0.6 & -- & 0.1 & 0.7 \\
Ampelopsis arborea & 0.6 & -- & 0.1 & 0.7 \\
& 100.0 & & 100.0 & 200.0
\end{tabular}


Table D-17

Importance Values for Species Occurring at Site 17. Arranged by Zone and Vegetation Layer

Species

$\begin{array}{cccc}\text { Percent } & \text { Percent } & \text { Percent } & \\ \text { Relative } & \text { Relative } & \text { Relative } & \text { Importance } \\ \text { Frequency } & \text { Density } & \text { Dominance } & \text { Value } \\ & & \end{array}$

\section{Zone 2}

\section{Trees}

Fraxinus caroliniana

Planera aquatica

Taxodium distichum

Nyssa biflora

Crataegus aestivalis

Cephalanthus occidentalis

Betula nigra

Acer rubrum

Saplings and Shrubs

Fraxinus caroliniana

Crataegus aestivalis

Planera aquatica

Cephalanthus occidentalis

Taxodium distichum

Quercus laurifolia

Leucothoe racemosa

Acer rubrum

Itea virginica

Quercus lyrata

Ilex verticillata

Lyonia lucida

Styrax americana

Cyrilla racemiflora

Betula nigra

Woody Vines

Smilax walteri

Herbs and Woody Seedlings

Fraxinus caroliniana

Planera aquatica

Crataegus aestivalis

Eleocharis microcarpa

Taxodium distichum

Quercus laurifolia

Fraxinus pennsylvanica

$\begin{array}{r}25.0 \\ 17.5 \\ 20.0 \\ 12.5 \\ 15.0 \\ 5.0 \\ 2.5 \\ 2.5 \\ \hline 100.0\end{array}$

18.2

18.2

16.4

9.1

7.3

5.5

5.5

3.6

3.6

3.6

1.8

1.8

1.8

1.8

$\frac{1.8}{100.0}$

100.0

37.1

25.9

14.8

7.4

3.7

3.7

3.7

$\begin{array}{r}58.8 \\ 20.6 \\ 6.9 \\ 3.9 \\ 7.3 \\ 1.7 \\ 0.4 \\ 0.4 \\ \hline 100.0\end{array}$

71.8

10.6

8.7

3.3

1.4

1.1

0.87

0.6

0.7

0.3

0.3

0.1

0.1

0.1

$\frac{0.1}{100.0}$

100.0

100.0
300.0

118.1

59.3

47.7

33.2

27.6

7.4

3.4

$\frac{0.4}{100.0}$

$\frac{3.3}{300.0}$

163.0

39.8

33.4

15.8

9.9

7.7

6.6

4.8

4.6

4.2

2. 2

2.0

2.0

2.0

0.1

$\frac{0.1}{100.0}$

$\frac{2.0}{300.0}$

45.5

82.6

28.6

18.2

54.5

33.0

2.5

9.9

1. 3

5.0

5.0

1.3

5.0 
Table D-17--continued

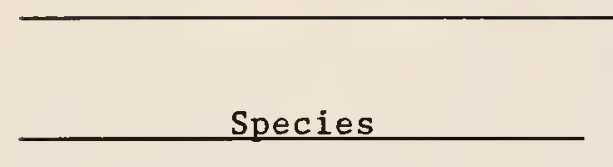

Boehmeria cylindrica

Trees

Nyssa biflora

Quercus laurifolia

Acer rubrum

Liquidambar styraciflua

Fraxinus caroliniana

Taxodium distichum

Ilex myrtifolia

Cyrilla racemiflora

Persea borbonia

Saplings and Shrubs

Fraxinus caroliniana

Acer rubrum

Quercus laurifolia

Nyssa biflora

Crataegus aestivalis

Cyrilla racemiflora

Styrax americana

Ilex myrtifolia

Liquidambar styraciflua

Leucothoe racemosa

Vaccinium elliottii

Clethra alnifolia

Itea virginica

Persea borbonia

Symplocos tinctoria

Myrica cerifera

Quercus lyrata

Quercus nigra

Lyonia lucida

Woody Vines

Smilax laurifolia

Gelsemium rankinii

Berchemia scandens

Smilax walteri

Smilax glauca

$\begin{array}{cccc}\text { Percent } & \text { Percent } & \text { Percent } & \\ \text { Relative } & \text { Relative } & \text { Relative } & \text { Importance } \\ \text { Frequency } & \text { Density } & \text { Dominance } & \text { Value } \\ & & \end{array}$

$\frac{3.7}{100.0}$

$\frac{1.3}{100.0}$

$\frac{5.0}{200.0}$

\section{Zone 3}

$\begin{array}{rrrr}23.2 & 37.1 & 63.6 & 123.9 \\ 23.2 & 32.3 & 18.8 & 74.3 \\ 20.9 & 15.0 & 12.0 & 47.9 \\ 9.3 & 3.1 & 0.8 & 13.2 \\ 4.7 & 4.7 & 0.8 & 10.2 \\ 4.7 & 2.3 & 3.0 & 10.0 \\ 7.0 & 2.3 & 0.5 & 9.8 \\ 4.7 & 1.6 & 0.2 & 6.5 \\ 2.3 & 1.6 & 0.3 & \frac{4.2}{300.0}\end{array}$

\begin{tabular}{rrrr}
11.8 & 23.2 & 25.7 & 60.7 \\
9.5 & 17.8 & 19.7 & 47.0 \\
9.5 & 12.4 & 16.3 & 38.2 \\
6.4 & 9.2 & 8.6 & 24.2 \\
7.4 & 8.8 & 7.9 & 24.1 \\
7.4 & 5.2 & 5.0 & 17.6 \\
8.5 & 4.4 & 4.0 & 16.9 \\
7.4 & 4.4 & 3.7 & 15.5 \\
6.4 & 1.8 & 1.7 & 9.9 \\
6.4 & 2.2 & 1.3 & 9.9 \\
4.3 & 1.6 & 0.8 & 6.7 \\
2.1 & 3.0 & 1.5 & 6.6 \\
3.2 & 2.2 & 1.0 & 6.4 \\
3.2 & 1.6 & 1.2 & 6.0 \\
1.1 & 1.0 & 0.7 & 2.8 \\
2.1 & 0.4 & 0.2 & 2.7 \\
1.1 & 0.4 & 0.4 & 1.9 \\
1.1 & 0.2 & 0.2 & 1.5 \\
1.1 & 0.2 & 0.1 & 1.4 \\
\hline 100.0 & 100.0 & 100.0 & 300.0
\end{tabular}

24.0

51.9

68.6

144.5

28.0

17.3

5.0

50.3

20.0

11.1

16.4

47.5

12.0

9.9

3.0

24.9

4.0

3.7

2. 2

9.9 
Table D-17--continued

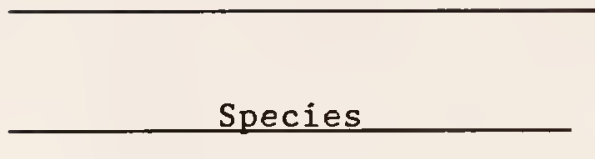

\begin{tabular}{crcr}
$\begin{array}{c}\text { Percent } \\
\text { Relative } \\
\text { Frequency }\end{array}$ & $\begin{array}{c}\text { Percent } \\
\text { Relative } \\
\text { Density }\end{array}$ & $\begin{array}{c}\text { Percent } \\
\text { Relative } \\
\text { Dominance }\end{array}$ & $\begin{array}{c}\text { Importance } \\
\text { Dalue }\end{array}$ \\
\cline { 5 - 5 } 4.0 & 3.7 & 1.0 & 8.7 \\
4.0 & 1.2 & 3.0 & 8.2 \\
$\frac{4.0}{100.0}$ & $\frac{1.2}{100.0}$ & $\frac{0.8}{100.0}$ & $\frac{6.0}{300.0}$
\end{tabular}

Herbs and Woody Seedlings

Ascyrum hypericoides
Mitchella repens
Quercus laurifolia
Fraxinus caroliniana
Acer rubrum
Smilax laurifolia
Gelsemium rankinii
Berchemia scandens
Itea virginica
Carex joorii
Nyssa sylvatica
Centella erecta
Cyrilla racemiflora
Smilax hispida
Persea borbonia
Liquidambar styraciflua
Woodwardia virginica
Toxicodendron radicans
Smilax walteri
Nyssa biflora
Gelsemium sempervirens
Crataegus viridis
Carex sp.

\begin{tabular}{|c|c|c|c|}
\hline 10.3 & $\cdots$ & 26.6 & 36.9 \\
\hline 6.9 & $\cdots$ & 16.7 & 23.6 \\
\hline 13.7 & $\ldots$ & 8.6 & 22.3 \\
\hline 10.3 & - & 8.9 & 19.2 \\
\hline 9.5 & - - & 6.5 & 16.0 \\
\hline 11.1 & - - & 4.3 & 15.4 \\
\hline 6.9 & -- & 6.8 & 13.7 \\
\hline 6.9 & - - & 4.3 & 11.2 \\
\hline 4.3 & $\cdots$ & 2.4 & 6.7 \\
\hline 4.3 & - - & 2.4 & 6.7 \\
\hline 0.9 & - - & 3.6 & 4.5 \\
\hline 1.7 & $\ldots$ & 1.7 & 3.4 \\
\hline 2.6 & $\cdots$ & 0.7 & 3.3 \\
\hline 0.9 & $\ldots$ & 1.5 & 2.4 \\
\hline 0.9 & - - & 1.5 & 2.4 \\
\hline 0.9 & $\ldots$ & 1.5 & 2.4 \\
\hline 1.7 & $\cdots$ & 0.5 & 2.2 \\
\hline 1.7 & $\cdots$ & 0.5 & 2.2 \\
\hline 0.9 & - & 0.2 & 1.1 \\
\hline 0.9 & -. & 0.2 & 1.1 \\
\hline 0.9 & - - & 0.2 & 1.1 \\
\hline 0.9 & $\cdots$ & 0.2 & 1.1 \\
\hline 0.9 & $\ldots$ & 0.2 & 1.1 \\
\hline 100.0 & & 100.0 & 200.0 \\
\hline
\end{tabular}

Zone 4

\section{Trees}

Acer rubrum

Ilex opaca

Nyssa sylvatica

Gordonia lasianthus

Liquidambar styraciflua

Quercus nigra

Persea borbonia

$P$ inus taeda

Quercus michauxii

Symplocos tinctoria

Quercus phellos

\begin{tabular}{rrrr}
18.7 & 33.7 & 29.2 & 81.6 \\
16.4 & 14.7 & 3.5 & 34.6 \\
11.6 & 9.5 & 12.8 & 33.9 \\
9.3 & 9.5 & 10.9 & 29.7 \\
9.3 & 6.8 & 12.4 & 28.5 \\
11.6 & 8.1 & 7.3 & 27.0 \\
11.6 & 9.5 & 2.1 & 23.2 \\
2.3 & 2.7 & 13.5 & 18.5 \\
2.3 & 1.4 & 7.1 & 10.8 \\
4.6 & 2.7 & 0.7 & 8.0 \\
2.3 & 1.4 & 0.5 & 4.2 \\
\hline 100.0 & 100.0 & 100.0 & 300.0
\end{tabular}


Table D-17--continued

\begin{tabular}{|c|c|c|c|c|}
\hline Species & 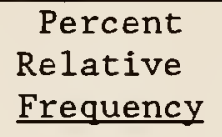 & $\begin{array}{r}\text { Percent } \\
\text { Relative } \\
\text { Density } \\
\end{array}$ & $\begin{array}{c}\text { Percent } \\
\text { Relative } \\
\text { Dominance } \\
\end{array}$ & $\begin{array}{c}\text { Importance } \\
\text { Value } \\
\end{array}$ \\
\hline \multicolumn{5}{|l|}{ Saplings and Shrubs } \\
\hline Ilex opaca & 12.6 & 35.3 & 41.4 & 89.3 \\
\hline Ilex coriacea & 8.8 & 15.0 & 11.6 & 35.4 \\
\hline Vaccinium fuscatum & 12.6 & 10.7 & 10.9 & 34.2 \\
\hline Persea borbonia & 12.6 & 11.6 & 9.2 & 33.4 \\
\hline Gordonia lasianthus & 5.1 & 67.5 & 6.6 & 18.2 \\
\hline Acer rubrum & 7.6 & 3.7 & 4.1 & 15.4 \\
\hline Symplocos tinctoria & 7.6 & 3.1 & 3.9 & 14.6 \\
\hline Clethra alnifolia & 6.4 & 4.3 & 2.8 & 13.5 \\
\hline Quercus nigra & 5.1 & 4.0 & 3.1 & 12.2 \\
\hline Cyrilla racemiflora & 5.1 & 1.6 & 1.4 & 8.1 \\
\hline Magnolia virginiana & 3.8 & 1.2 & 1.7 & 6.7 \\
\hline Quercus michauxii & 3.8 & 0.9 & 1.6 & 6.3 \\
\hline Prunus serotina & 2.5 & 0.6 & 0.5 & 3.6 \\
\hline Lyonia lucida & 2.5 & 0.6 & 0.4 & 3.5 \\
\hline Sebastiania fruticosa & 1.3 & 0.3 & 0.4 & 2.0 \\
\hline Myrica cerifera & 1.3 & 0.3 & 0.2 & 1.8 \\
\hline \multirow{2}{*}{ Leucothoe racemosa } & 1.3 & $\underline{0.3}$ & 0.2 & 1.8 \\
\hline & $\overline{100.0}$ & 100.0 & $\overline{100.0}$ & $\overline{300.0}$ \\
\hline \multicolumn{5}{|l|}{ Woody Vines } \\
\hline Smilax laurifolia & 33.2 & 44.4 & 65.5 & 143.1 \\
\hline Smilax walteri & 42.6 & 43.4 & 21.3 & 107.3 \\
\hline Vitis rotundifolia & 19.5 & 6.6 & 11.1 & 37.2 \\
\hline \multirow[t]{2}{*}{ Smilax glauca } & 4.7 & 5.6 & 2.1 & 12.4 \\
\hline & 100.0 & 100.0 & 100.0 & 300.0 \\
\hline \multicolumn{5}{|c|}{ Herbs and Woody Seedlings } \\
\hline Ilex coriacea & 8.7 & -- & 16.4 & 25.1 \\
\hline Woodwardia areolata & 10.9 & - & 13.1 & 24.0 \\
\hline Persea borbonia & 13.0 & -- & 10.1 & 23.1 \\
\hline Leucothoe axillaris & 4.3 & - & 18.5 & 22.8 \\
\hline Mitchella repens & 13.0 & -- & 9.3 & 22.3 \\
\hline Clethra alnifolia & 7.6 & - & 7.9 & 15.5 \\
\hline Symplocos tinctoria & 6.5 & - & 5.5 & 12.0 \\
\hline Quercus nigra & 6.5 & $\cdots$ & 2.4 & 8.9 \\
\hline Asarum arifolium & 5.4 & - & 2.2 & 7.6 \\
\hline Ilex opaca & 4.3 & -- & 2.0 & 6.3 \\
\hline Osmunda cinnamomea & 3.3 & - & 1.8 & 5.1 \\
\hline Smilax rotundifolia & 1.1 & - & 3.3 & 4.4 \\
\hline Smilax glauca & 3.3 & - & 0.6 & 3.9 \\
\hline Smilax walteri & 2.2 & -- & 1.6 & 3.8 \\
\hline Quercus michauxii & 2.2 & - & 1.6 & 3.8 \\
\hline Vaccinium sp. & 1.1 & - & 1.4 & 2.5 \\
\hline Woodwardia virginica & 1.1 & - & 1.3 & 2.4 \\
\hline Vitis rotundifolia & 1.1 & -- & 0.2 & 1.3 \\
\hline
\end{tabular}


Table D-17--continued

\begin{tabular}{|c|c|c|c|c|}
\hline Species & 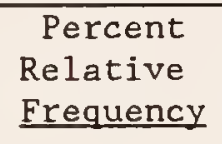 & $\begin{array}{r}\text { Percent } \\
\text { Relative } \\
\text { Density } \\
\end{array}$ & $\begin{array}{r}\text { Percent } \\
\text { Relative } \\
\text { Dominance } \\
\end{array}$ & $\begin{array}{c}\text { Importance } \\
\text { Value }\end{array}$ \\
\hline Vaccinium corymbosum & 1.1 & - & 0.2 & 1.3 \\
\hline Nyssa sylvatica & 1.1 & - & 0.2 & 1.3 \\
\hline Cyrilla racemiflora & 1.1 & -- & 0.2 & 1.3 \\
\hline \multirow[t]{3}{*}{ Carex sp. } & 1.1 & - & 0.2 & 1.3 \\
\hline & 100.0 & & 100.0 & $\overline{200.0}$ \\
\hline & Zone 6 & & & \\
\hline \multicolumn{5}{|l|}{$\underline{\text { Trees }}$} \\
\hline Quercus nigra & 43.6 & 59.3 & 37.1 & 140.0 \\
\hline Pinus taeda & 26.2 & 18.7 & 44.6 & 89.5 \\
\hline Liquidambar styraciflua & 13.0 & 9.4 & 9.7 & 32.1 \\
\hline Quercus virginiana & 4.3 & 6.3 & 6.6 & 17.2 \\
\hline Symplocos tinctoria & 4.3 & 3.1 & 1.4 & 8.8 \\
\hline Sassafras albidum & 4.3 & 1.6 & 0.3 & 6.2 \\
\hline \multirow[t]{2}{*}{ Ilex opaca } & 4.3 & 1.6 & 0.3 & 6.2 \\
\hline & $\overline{100.0}$ & $\overline{100.0}$ & $\overline{100.0}$ & 300.0 \\
\hline \multicolumn{5}{|l|}{ Saplings and Shrubs } \\
\hline Symplocos tinctoria & 11.5 & 51.6 & 46.0 & 109.1 \\
\hline Quercus nigra & 10.5 & 12.3 & 16.2 & 39.0 \\
\hline Sassafras albidum & 9.3 & 7.1 & 8.0 & 24.4 \\
\hline Liquidambar styraciflua & 10.4 & 6.1 & 7.2 & 23.7 \\
\hline Ilex opaca & 8.2 & 3.9 & 4.8 & 16.9 \\
\hline Myrica cerifera & 5.8 & 4.7 & 4.1 & 14.6 \\
\hline Vaccinium elliottii & 7.0 & 3.0 & 2.4 & 12.4 \\
\hline Acer rubrum & 5.8 & 3.0 & 3.4 & 12.2 \\
\hline Persea borbonia & 5.8 & 1.8 & 1.4 & 9.0 \\
\hline Castanea pumila & 4.6 & 1.8 & 1.5 & 7.9 \\
\hline Nyssa sylvatica & 3.5 & 0.9 & 1.8 & 6.2 \\
\hline Quercus falcata & 3.5 & 0.7 & 0.4 & 4.6 \\
\hline Prunus serotina & 2.3 & 0.9 & 0.8 & 4.0 \\
\hline Quercus virginiana & 2.3 & 0.4 & 0.5 & 3.2 \\
\hline Cornus florida & 2.3 & 0.4 & 0.4 & 3.1 \\
\hline Vaccinium arboreum & 1.2 & 0.4 & 0.4 & 2.0 \\
\hline Vaccinium fuscatum & 1.2 & 0.2 & 0.2 & 1.6 \\
\hline Quercus stellata & 1.2 & 0.2 & 0.2 & 1.6 \\
\hline Quercus michauxii & 1.2 & 0.2 & 0.1 & 1.5 \\
\hline Ilex coriacea & 1.2 & 0.2 & 0.1 & 1.5 \\
\hline \multirow[t]{2}{*}{ Diospyros virginiana } & 1.2 & 0.2 & 0.1 & 1.5 \\
\hline & 100.0 & 100.0 & 100.0 & 300.0 \\
\hline \multicolumn{5}{|l|}{ Woody Vines } \\
\hline$\overline{\text { Vitis rotundifolia }}$ & 46.1 & 50.0 & 55.0 & 151.1 \\
\hline \multirow[t]{2}{*}{ Gelsemium sempervirens } & 53.9 & 50.0 & 45.0 & $\underline{148.9}$ \\
\hline & $\overline{100.0}$ & $\overline{100.0}$ & $\overline{100.0}$ & 300.0 \\
\hline
\end{tabular}


Table D-17--continued

\begin{tabular}{|c|c|c|c|c|}
\hline Species & 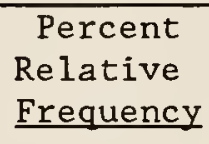 & $\begin{array}{r}\text { Percent } \\
\text { Relative } \\
\text { Density } \\
\end{array}$ & $\begin{array}{c}\text { Percent } \\
\text { Relative } \\
\text { Dominance }\end{array}$ & $\begin{array}{c}\text { Importance } \\
\text { Value }\end{array}$ \\
\hline \multicolumn{5}{|l|}{ Herbs and Woody Seedlings } \\
\hline Quercus nigra & 17.7 & - & 20.7 & 38.4 \\
\hline Symplocos tinctoria & 8.8 & - & 12.7 & 27.4 \\
\hline Sassafras albidum & 14.7 & - & 12.7 & 27.4 \\
\hline Nyssa sylvatica & 7.8 & -- & 12.8 & 20.6 \\
\hline Persea borbonia & 8.8 & -- & 10.8 & 19.6 \\
\hline Chimaphila maculata & 4.9 & - & 3.8 & 8.7 \\
\hline Vitis rotundifolia & 3.9 & -- & 2.3 & 6.2 \\
\hline Tragia urens & 3.9 & - & 2.3 & 6.2 \\
\hline Liquidambar styraciflua & 3.9 & -- & 2.3 & 6.2 \\
\hline Gelsemium sempervirens & 2.0 & - & 1.8 & 3.8 \\
\hline Smilax glauca & 2.9 & - & 0.7 & 3.6 \\
\hline Pinus taeda & 2.9 & - & 0.7 & 3.6 \\
\hline Ilex opaca & 2.9 & - & 0.7 & 3.6 \\
\hline Cnidoscolus stimulosus & 2.9 & - & 0.7 & 3.6 \\
\hline Dichanthelium commutatum & 2.0 & -- & 0.5 & 2.5 \\
\hline Vaccinium elliottii & 1.0 & - & 1.5 & 2.5 \\
\hline Quercus velutina & 1.0 & - & 1.5 & 2.5 \\
\hline Lonicera sempervirens & 1.0 & -- & 1.5 & 2.5 \\
\hline Smilax hispida & 1.0 & - & 0.2 & 1.2 \\
\hline Sebastiania fruticosa & 1.0 & - & 0.2 & 1.2 \\
\hline Rhus copallinum & 1.0 & - & 0.2 & 1.2 \\
\hline Unknown & 1.0 & -- & 0.2 & 1.2 \\
\hline Mitchella repens & 1.0 & - & 0.2 & 1.2 \\
\hline Carex sp. & 1.0 & - & 0.2 & 1.2 \\
\hline \multirow[t]{2}{*}{ Andropogon virginicus } & 1.0 & - & 0.2 & 1.2 \\
\hline & $\overline{100.0}$ & & $\overline{100.0}$ & $\overline{200.0}$ \\
\hline
\end{tabular}


APPENDIX E

FTI PLANT LIST AND COMPARISON WITH TWO

OTHER WATER-TOLERANCE RATING SYSTEMS 
Table E-1

FTI Plant List

\begin{tabular}{|c|c|c|c|c|}
\hline Species & $\begin{array}{c}\text { Species } \\
\text { Code }\end{array}$ & $\mathrm{FTI}^{\mathrm{a}}-\mathrm{SD}$ & $\begin{array}{r}\text { NWI }^{\mathrm{b}} \\
\text { Status } \\
\text { Region } 2 \\
\end{array}$ & $\begin{array}{l}\text { Water } \\
\text { Logging } \\
\text { Tolerance } \\
\text { Ratings } \\
\text { (WLT) } \\
\end{array}$ \\
\hline \multicolumn{5}{|c|}{ Trees } \\
\hline Acer drummondi $i$ & ACDR & $3.48 \pm 0.12$ & OBL & \\
\hline Acer negundo & $\mathrm{ACNE}$ & $4.83 \pm 0.47$ & FACW & $\begin{array}{r}\text { Moderately } \\
\text { tolerant }\end{array}$ \\
\hline Acer rubrum & ACRU & $4.21 \pm 0.68$ & FAC & $\begin{array}{r}\text { Moderately } \\
\text { tolerant }\end{array}$ \\
\hline Acer saccharinum & ACSA & $3.75 \pm 0.36$ & FACW & $\begin{array}{r}\text { Moderately } \\
\text { tolerant }\end{array}$ \\
\hline Betula nigra & BENI & $4.01 \pm 1.73$ & OBL & $\begin{array}{r}\text { Moderately } \\
\text { tolerant }\end{array}$ \\
\hline Bumelia lanuginosa & BULA & $6.50 \pm 0.00$ & FACU & \\
\hline Bumelia lycoides & BULY & $4.50 \pm 0.00$ & FACW & \\
\hline Carpinus caroliniana & CACA & $4.84 \pm 0.61$ & FAC & $\begin{array}{l}\text { Weakly } \\
\quad \text { tolerant }\end{array}$ \\
\hline Carya aquatica & CAAQ & $3.54 \pm 0.34$ & OBL & $\begin{array}{l}\text { Highly } \\
\text { tolerant }\end{array}$ \\
\hline Carya glabra & CAGL & $6.50 \pm 0.00$ & FACU & \\
\hline Carya illinoensis & CAIL & $5.57 \pm 1.01$ & FAC & $\begin{array}{l}\text { Weakly } \\
\text { tolerant }\end{array}$ \\
\hline Carya tomentosa & CATO & $6.50 \pm 0.00$ & UPL & \\
\hline Celtis laevigata & CELA & $4.84 \pm 0.56$ & FACW & $\begin{array}{l}\text { Weakly } \\
\text { tolerant }\end{array}$ \\
\hline Cephalanthus occidentalis & CEOC & $2.83 \pm 0.52$ & $\mathrm{OBL}$ & $\begin{array}{l}\text { Most } \\
\quad \text { tolerant }\end{array}$ \\
\hline Cercis canadensis & CECA & $5.50 \pm 1.40$ & FACU & \\
\hline Cornus drummondii & CODR & $4.50 \pm 0.00$ & FAC & \\
\hline Cornus florida & COFL & $6.50 \pm 0.00$ & FACU & $\begin{array}{l}\text { Least } \\
\text { tolerant }\end{array}$ \\
\hline Cornus foemina & COFO & $5.50 \pm 0.00$ & FACW - & \\
\hline Crataegus aestivilis & CRAE & $3.00 \pm 0.70$ & OBL & $\begin{array}{r}\text { Moderately } \\
\text { tolerant }\end{array}$ \\
\hline Crataegus viridis & CRVI & $4.52 \pm 0.58$ & FACW & $\begin{array}{r}\text { Moderately } \\
\text { tolerant }\end{array}$ \\
\hline Cyrilla racemiflora & CYRA & $3.50 \pm 0.00$ & FACW & \\
\hline
\end{tabular}

a Mean for all study sites.

b Taken from Reed (1988); definitions are at the end of the appendix.

c Taken from Hook (1984); definitions are at the end of the appendix. 
Table E-1--continued

\begin{tabular}{|c|c|c|c|c|}
\hline Species & $\begin{array}{l}\text { Species } \\
\text { Code }\end{array}$ & $\mathrm{FTI}^{\mathrm{a}}-\mathrm{SD}$ & $\begin{array}{c}\text { NWI }^{\mathrm{b}} \\
\text { Status } \\
\text { Region 2 }\end{array}$ & $\begin{array}{l}\text { Water } \\
\text { Logging } \\
\text { Tolerance } \\
\text { Ratingsc } \\
\text { (WLT) }\end{array}$ \\
\hline Diospyros virginiana & DIVI & $4.13 \pm 0.82$ & FAC & $\begin{array}{r}\text { Moderately } \\
\text { tolerant }\end{array}$ \\
\hline Fagus grandifolia & FAGR & $6.50 \pm 0.00$ & FACU & $\begin{array}{l}\text { Least } \\
\quad \text { tolerant }\end{array}$ \\
\hline Forestiera acuminata & FOAC & $3.48 \pm 0.50$ & OBL & $\begin{array}{l}\text { Most } \\
\quad \text { tolerant }\end{array}$ \\
\hline Fraxinus americana & FRAM & $6.50 \pm 0.00$ & FACU & \\
\hline Fraxinus caroliniana & FRCA & $2.87 \pm 0.41$ & OBL & $\begin{array}{l}\text { Most } \\
\quad \text { tolerant }\end{array}$ \\
\hline Fraxinus pennsylvanica & FRPE & $4.44 \pm 0.67$ & FACW & $\begin{array}{r}\text { Moderately } \\
\text { tolerant }\end{array}$ \\
\hline Gleditsia aquatica & GLAQ & $3.50 \pm 0.00$ & OBL & $\begin{array}{l}\text { Highly } \\
\text { tolerant }\end{array}$ \\
\hline Gordonia lasianthus & GOLA & $4.50 \pm 0.00$ & FACW & $\begin{array}{r}\text { Moderately } \\
\text { tolerant }\end{array}$ \\
\hline Halesia carolina & HACA & $6.50 \pm 0.00$ & FACU+ & \\
\hline Halesia diptera & HADI & $6.19 \pm 0.43$ & FAC & \\
\hline Ilex decidua & ILDE & $4.35 \pm 0.83$ & FACW & $\begin{array}{r}\text { Moderately } \\
\text { tolerant }\end{array}$ \\
\hline Ilex myrtifolia & ILMY & $3.50 \pm 0.00$ & FACW & \\
\hline Ilex opaca & ILOP & $5.79 \pm 0.72$ & FACU+ & $\begin{array}{l}\text { Weakly } \\
\text { tolerant }\end{array}$ \\
\hline Juglans nigra & JUNI & $6.50 \pm 0.00$ & FACU & $\begin{array}{l}\text { Weakly } \\
\text { tolerant }\end{array}$ \\
\hline Juniperus virginiana & JUVI & $6.50 \pm 0.00$ & FACU & $\begin{array}{l}\text { Least } \\
\text { tolerant }\end{array}$ \\
\hline Liquidambar styraciflua & LIST & $5.03 \pm 0.65$ & FAC+ & $\begin{array}{r}\text { Moderately } \\
\text { tolerant }\end{array}$ \\
\hline Malus angustifolia & MAAN & $6.50 \pm 0.00$ & UPL & \\
\hline Melia azedarach & MEAZ & $5.54 \pm 0.00$ & UPL & \\
\hline Morus rubra & MORU & $5.75 \pm 0.96$ & FAC & $\begin{array}{l}\text { Weakly } \\
\text { tolerant }\end{array}$ \\
\hline Nyssa aquatica & NYAQ & $2.62 \pm 0.20$ & OBL & $\begin{array}{l}\text { Most } \\
\quad \text { tolerant }\end{array}$ \\
\hline Nyssa biflora & NYBI & $3.04 \pm 0.47$ & OBL & $\begin{array}{l}\text { Most } \\
\quad \text { tolerant }\end{array}$ \\
\hline Nyssa ogeche & NYOG & $2.64 \pm 0.00$ & OBL & \\
\hline Nyssa sylvatica & NYSY & $5.27 \pm 0.65$ & FAC & $\begin{array}{l}\text { Weakly } \\
\text { tolerant }\end{array}$ \\
\hline Ostrya virginiana & OSVI & $6.50 \pm 0.00$ & FACU - & $\begin{array}{l}\text { Least } \\
\quad \text { tolerant }\end{array}$ \\
\hline Persea borbonia & PEBO & $4.35 \pm 0.00$ & FACW & $\begin{array}{r}\text { Moderately } \\
\text { tolerant }\end{array}$ \\
\hline Pinus echinata & PIEC & $6.50 \pm 0.00$ & UPL & $\begin{array}{l}\text { Least } \\
\text { tolerant }\end{array}$ \\
\hline
\end{tabular}


Table E-1--continued

\begin{tabular}{|c|c|c|c|c|}
\hline Species & $\begin{array}{l}\text { Species } \\
\text { Code }\end{array}$ & $\mathrm{FTI}^{\mathrm{a}}-\mathrm{SD}$ & $\begin{array}{c}\text { NWI }^{\mathrm{b}} \\
\text { Status } \\
\text { Region } 2 \\
\end{array}$ & $\begin{array}{l}\text { Water } \\
\text { Logging } \\
\text { Tolerance } \\
\text { Ratings } \\
\text { (WLT) } \\
\end{array}$ \\
\hline Pinus elliottii & PIEL & $5.50 \pm 0.00$ & FACW & \\
\hline Pinus glabra & PIGL & $6.24 \pm 0.37$ & FACW & $\begin{array}{l}\text { Weakly } \\
\text { tolerant }\end{array}$ \\
\hline Pinus taeda & PITA & $6.41 \pm 0.14$ & FAC & $\begin{array}{r}\text { Moderately } \\
\text { tolerant }\end{array}$ \\
\hline Planera aquatica & PLAQ & $3.12 \pm 0.68$ & OBL & $\begin{array}{l}\text { Most } \\
\quad \text { tolerant }\end{array}$ \\
\hline Platanus occidentalis & PLOC & $5.18 \pm 0.00$ & FACW- & $\begin{array}{r}\text { Moderately } \\
\text { tolerant }\end{array}$ \\
\hline Quercus alba & QUAL & $6.50 \pm 0.00$ & FACU & $\begin{array}{l}\text { Least } \\
\quad \text { tolerant }\end{array}$ \\
\hline Quercus falcata & QUFA & $6.50 \pm 0.00$ & FACU - & \\
\hline $\begin{array}{l}\text { Quercus falcata } \\
\text { var. pagodifolia }\end{array}$ & QUPA & $6.39 \pm 0.31$ & FAC+ & $\begin{array}{l}\text { Weakly } \\
\text { tolerant }\end{array}$ \\
\hline Quercus laurifolia & QULA & $3.89 \pm 0.38$ & FACW & $\begin{array}{l}\text { Weakly } \\
\text { tolerant }\end{array}$ \\
\hline Quercus lyrata & QULY & $3.73 \pm 0.68$ & OBL & $\begin{array}{l}\text { Highly } \\
\text { tolerant }\end{array}$ \\
\hline Quercus michauxii & QUMI & $4.81 \pm 0.61$ & FACW & $\begin{array}{l}\text { Weakly } \\
\text { tolerant }\end{array}$ \\
\hline Quercus nigra & QUNI & $5.73 \pm 0.69$ & FAC & \\
\hline Quercus nuttallii & QUNU & $4.50 \pm 0.00$ & OBL & $\begin{array}{l}\text { Moderately } \\
\text { tolerant }\end{array}$ \\
\hline Quercus palustris & QUPA & $4.00 \pm 0.00$ & FACW & $\begin{array}{r}\text { Moderately } \\
\text { tolerant }\end{array}$ \\
\hline Quercus phellos & QUPH & $4.81 \pm 1.07$ & FACW & $\begin{array}{r}\text { Moderately } \\
\text { tolerant }\end{array}$ \\
\hline Quercus shumardii & QUSH & $5.50 \pm 0.00$ & FACW & $\begin{array}{l}\text { Weakly } \\
\text { tolerant }\end{array}$ \\
\hline Ouercus stellata & QUST & $6.50 \pm 0.00$ & FACU & \\
\hline Quercus virginiana & QUVI & $6.50 \pm 0.00$ & FACU+ & $\begin{array}{l}\text { Weakly } \\
\text { tolerant }\end{array}$ \\
\hline Quercus velutina & QUVE & $6.50 \pm 0.00$ & & \\
\hline Salix nigra & SANI & $2.83 \pm 0.58$ & OBL & $\begin{array}{l}\text { Most } \\
\text { tolerant }\end{array}$ \\
\hline Sassafras albidum & SAAL & $6.50 \pm 0.00$ & FACU & $\begin{array}{l}\text { Least } \\
\text { tolerant }\end{array}$ \\
\hline Symplocos tinctoria & SYTI & $5.54 \pm 0.00$ & FAC & \\
\hline Taxodium distichum & TADI & $2.97 \pm 0.61$ & OBL & $\begin{array}{l}\text { Most } \\
\text { tolerant }\end{array}$ \\
\hline Ulmus alata & ULAL & $6.43 \pm 0.13$ & FACU+ & $\begin{array}{l}\text { Weakly } \\
\text { tolerant }\end{array}$ \\
\hline Ulmus americana & ULAM & $4.46 \pm 0.62$ & FACW & $\begin{array}{r}\text { Moderately } \\
\text { tolerant }\end{array}$ \\
\hline
\end{tabular}


Table E-1--continued

\begin{tabular}{|c|c|c|c|c|}
\hline Species & $\begin{array}{c}\text { Species } \\
\text { Code }\end{array}$ & $\mathrm{FTI}^{\mathrm{a}}-\mathrm{SD}$ & $\begin{array}{c}\text { NWI }^{\mathrm{b}} \\
\text { Status } \\
\text { Region } 2 \\
\end{array}$ & $\begin{array}{l}\text { Water } \\
\text { Logging } \\
\text { Tolerance } \\
\text { Ratings }{ }^{c} \\
\text { (WLT) } \\
\end{array}$ \\
\hline Ulmus rubra & ULRU & $5.50 \pm 0.00$ & FAC & $\begin{array}{l}\text { Least } \\
\quad \text { tolerant }\end{array}$ \\
\hline Vaccinium arboreum & VAAR & $6.50 \pm 0.00$ & FACU & \\
\hline
\end{tabular}


Table E-1--continued

Species

\begin{tabular}{l} 
Species \\
\hline \\
\\
Acer drummondii \\
Acer negundo \\
Acer rubrum \\
Acer saccharinum \\
Amelanchier arborea \\
Amorpha fruiticosa \\
Aralia spinosa \\
Arundinaria gigantea \\
Ascyrum hypercoides \\
Asimina parviflora \\
Asimina triloba \\
Betula nigra \\
Bumelia lanuginosa \\
Callicarpa americana \\
Carpinus caroliniana \\
Carya aquatica \\
Carya glabra \\
Carya illinoensis \\
Carya tomentosa \\
Castanea pumila \\
Celtis laevigata \\
Cephalanthus occidentalis \\
Cercis canadensis \\
Chionanthus virginicus \\
Clethera alnifolia \\
Cornus drummondi \\
Cornus florida \\
Cornus foemina \\
Crataegus aestivalis \\
Crataegus flava \\
Crataegus marshallii \\
Crataegus viridis \\
Cyrilla racemiflora \\
Diospyos virginiana \\
Fagus grandifolia \\
Forestiera acuminata \\
Fraxinus americana \\
Fraxinus caroliniana \\
Fraxinus pennsylvanica \\
Gaylussacia frondosa \\
Gleditsia aquatica \\
Gleditsia triacanthos \\
Gordonia lasianthus \\
Halesia carolina \\
Halesia diptera \\
Hymamelis virginiana \\
Gym galioides \\
\end{tabular}

Species Code

FTI SD

NWI Status

Saplings and Shrubs

\begin{tabular}{|c|c|c|}
\hline ACDR & $3.68 \pm 0.57$ & OBL \\
\hline ACNE & $5.20 \pm 0.99$ & FACW \\
\hline ACRU & $4.96 \pm 0.94$ & FAC \\
\hline ACSA & $3.50 \pm 0.00$ & FACW \\
\hline AMAB & $6.50 \pm 0.00$ & FACU \\
\hline AMFR & $4.08 \pm 0.59$ & FACW \\
\hline ARSP & $6.50 \pm 0.00$ & FAC \\
\hline ARGI & $5.41 \pm 1.66$ & FACW \\
\hline ASHY & $6.50 \pm 0.00$ & \\
\hline ASPA & $6.50 \pm 0.00$ & FACU \\
\hline ASTR & $6.50 \pm 0.00$ & FAC \\
\hline BENI & $4.50 \pm 2.00$ & OBL \\
\hline BULA & $5.91 \pm 0.00$ & FACU \\
\hline CAAM & $6.39 \pm 0.20$ & FACU- \\
\hline CACA & $5.07 \pm 0.43$ & FAC \\
\hline CAAQ & $3.70 \pm 0.38$ & OBL \\
\hline CAGL & $6.50 \pm 0.00$ & FACU \\
\hline CAIL & $5.00 \pm 0.71$ & FAC+ \\
\hline CATO & $6.50 \pm 0.00$ & UPL \\
\hline CAPU & $6.50 \pm 0.00$ & UPL \\
\hline CELA & $4.37 \pm 0.38$ & FACW \\
\hline CEOC & $3.13 \pm 0.44$ & OBL \\
\hline CECA & $6.37 \pm 0.22$ & FACU \\
\hline CHVI & $6.50 \pm 0.00$ & FACU \\
\hline CLAL & $5.32 \pm 1.67$ & FACW \\
\hline CODR & $5.69 \pm 0.90$ & FAC \\
\hline COFL & $6.50 \pm 0.00$ & FACU \\
\hline COFO & $4.70 \pm 0.90$ & FACW - \\
\hline CRAE & $2.98 \pm 0.15$ & $\mathrm{OBL}$ \\
\hline CRFL & $6.50 \pm 0.00$ & UPL \\
\hline CRMA & $5.37 \pm 1.63$ & FAC \\
\hline CRVI & $4.46 \pm 0.65$ & FACW \\
\hline CYRA & $3.72 \pm 0.00$ & FACW \\
\hline DIVI & $5.08 \pm 1.18$ & FAC \\
\hline FAGR & $6.50 \pm 0.00$ & FACU \\
\hline FOAC & $3.57 \pm 0.54$ & OBL \\
\hline FRAM & $6.50 \pm 0.00$ & FACU \\
\hline FRCA & $2.91 \pm 0.33$ & OBL \\
\hline FRPE & $4.27 \pm 0.70$ & FACW \\
\hline GAFR & $6.50 \pm 0.00$ & FAC \\
\hline GLAQ & $3.15 \pm 0.49$ & OBL \\
\hline GLTR & $6.50 \pm 0.00$ & FAC - \\
\hline GOLA & $4.50 \pm 0.00$ & FACW \\
\hline $\mathrm{HACA}$ & $6.50 \pm 0.00$ & FACU+ \\
\hline HADI & $6.09 \pm 0.57$ & FAC \\
\hline HAVI & $6.50 \pm 0.00$ & FACU \\
\hline HYGA & $4.30 \pm 0.00$ & OBL \\
\hline
\end{tabular}


Table E-1--continued

\begin{tabular}{|c|c|c|c|}
\hline Species & Species Code & FTI SD & NWI Status \\
\hline Ilex amelanchier & ILAM & $2.50 \pm 0.00$ & $\mathrm{OBL}$ \\
\hline Ilex coriacea & ILCO & $4.58 \pm 0.00$ & FACW \\
\hline Ilex decidua & ILDE & $4.57 \pm 0.73$ & FACW - \\
\hline Ilex glabra & ILGL & $6.50 \pm 0.00$ & FACW \\
\hline Ilex myrtifolia & ILMY & $3.50 \pm 0.00$ & FACW \\
\hline Ilex opaca & ILOP & $5.96 \pm 0.61$ & FACU+ \\
\hline Ilex verticillata & ILVE & $2.50 \pm 0.00$ & FACW \\
\hline Ilex vomitoria & ILVO & $6.50 \pm 0.00$ & FAC \\
\hline Itea virginica & ITVI & $2.83 \pm 0.35$ & FACW+ \\
\hline Juglans nigra & JUNI & $6.50 \pm 0.00$ & FACU \\
\hline Juniperus virginiana & JUVI & $6.50 \pm 0.00$ & FACU- \\
\hline Leucothoe racemosa & LERA & $4.06 \pm 1.17$ & FACW \\
\hline Lindera benzoin & LIBE & $5.82 \pm 0.00$ & FACW \\
\hline Liquidambar styraciflua & LIST & $5.52 \pm 0.76$ & FAC+ \\
\hline Lyonia lucida & LYLU & $3.71 \pm 0.00$ & FACW \\
\hline Magnolia grandiflora & MAGR & $5.43 \pm 0.09$ & FAC+ \\
\hline Magnolia virginiana & MAVI & $5.50 \pm 1.41$ & FACW+ \\
\hline Malus angustifolia & MAAN & $6.50 \pm 0.00$ & UPL \\
\hline Malus coronaria & MACO & $6.50 \pm 0.00$ & UPL \\
\hline Melia azedarach & MEAZ & $6.21 \pm 0.00$ & UPL \\
\hline Morus rubra & MORU & $6.25 \pm 0.50$ & FAC \\
\hline Myrica cerifera & MYCE & $6.19 \pm 0.43$ & FAC+ \\
\hline Nyssa aquatica & NYAQ & $3.25 \pm 0.50$ & OBL \\
\hline Nyssa biflora & NYBI & $3.50 \pm 0.00$ & OBL \\
\hline Nyssa ogeche & NYOG & $3.50 \pm 0.00$ & OBL \\
\hline Nyssa sylvatica & NYSY & $5.80 \pm 0.69$ & FAC \\
\hline Ostrya virginiana & OSVI & $6.50 \pm 0.00$ & FACU - \\
\hline Persea borbonia & PEBO & $4.78 \pm 1.23$ & FACW \\
\hline Pinus taeda & PITA & $6.50 \pm 0.00$ & FAC \\
\hline Planera aquatica & PLAQ & $3.01 \pm 0.64$ & $\mathrm{OBL}$ \\
\hline Platanus occidentalis & PLOC & $5.05 \pm 0.00$ & FACW- \\
\hline Poncirus trifoliata & POTR & $6.50 \pm 0.00$ & UPL \\
\hline Prunus serotina & PRSE & $6.26 \pm 0.47$ & FACU \\
\hline Prunus umbellata & PRUM & $6.50 \pm 0.00$ & UPL \\
\hline Quercus alba & QUAL & $6.50 \pm 0.00$ & FACU \\
\hline Quercus falcata & QUFA & $6.50 \pm 0.00$ & FACU - \\
\hline $\begin{array}{l}\text { Quercus falcata } \\
\text { var. pagodifolia }\end{array}$ & QUPA & $6.50 \pm 0.00$ & FAC+ \\
\hline Quercus laurifolia & QULA & $4.39 \pm 0.00$ & FACW \\
\hline Quercus lyrata & QULY & $3.99 \pm 1.00$ & OBL \\
\hline Quercus marilandica & QUMA & $6.50 \pm 0.00$ & UPL \\
\hline Quercus michauxii & QUMI & $5.34 \pm 0.33$ & FACW \\
\hline Quercus nigra & QUNI & $5.92 \pm 0.49$ & FAC \\
\hline Quercus nuttallii & QUNU & $4.50 \pm 0.00$ & $\mathrm{OBL}$ \\
\hline Quercus phellos & QUPH & $5.29 \pm 1.18$ & FACW - \\
\hline Quercus shumardii & QUSH & $5.50 \pm 0.00$ & FACW \\
\hline Quercus stellata & QUST & $6.50 \pm 0.00$ & FACU \\
\hline Quercus velutina & QUVE & $6.50 \pm 0.00$ & UPL \\
\hline Quercus virginiana & QUVI & $5.85 \pm 0.92$ & FACU+ \\
\hline
\end{tabular}


Table E-1--continued

\begin{tabular}{|c|c|c|c|}
\hline Species & Species Code & FTI SD & NWI Status \\
\hline Rhododendron canescens & $\mathrm{RHCN}$ & $6.50 \pm 0.00$ & UPL \\
\hline Rhus glabra & RHGL & $6.50 \pm 0.00$ & UPL \\
\hline Rhus copallinum & $\mathrm{RHCO}$ & $6.50 \pm 0.00$ & UPL \\
\hline Sabal minor & SAMI & $4.50 \pm 0.00$ & FACW \\
\hline Salix nigra & SANI & $2.83 \pm 0.58$ & OBL \\
\hline Sambucus canadensis & SACA & $5.95 \pm 0.77$ & FACW - \\
\hline Sapium sebiferum & SASE & $3.50 \pm 0.00$ & FAC \\
\hline Sassafras albidum & SAAL & $6.50 \pm 0.00$ & FACU \\
\hline Sebastiania fruticosa & SEFR & $4.45 \pm 0.67$ & UPL \\
\hline Styrax americana & STAM & $3.41 \pm 0.64$ & FACW \\
\hline Symplocos tinctoria & SYTI & $6.40 \pm 0.17$ & FAC \\
\hline Taxodium distichum & TADI & $3.33 \pm 0.71$ & OBL \\
\hline Ulmus alata & ULAL & $6.24 \pm 0.34$ & FACU+ \\
\hline Ulmus americana & ULAM & $4.81 \pm 0.74$ & FACW \\
\hline Ulmus crassifolia & ULCR & $6.50 \pm 0.00$ & FAC \\
\hline Ulmus rubra & ULRU & $5.75 \pm 0.50$ & FAC \\
\hline Vaccinium arboreum & VAAR & $6.45 \pm 0.13$ & FACU \\
\hline Vaccinium corymbosum & VACO & $6.50 \pm 0.00$ & \\
\hline Vaccinium elliottii & VAEL & $5.82 \pm 0.96$ & FAC+ \\
\hline Vaccinium fuscatum & VAFU & $4.50 \pm 0.00$ & FAC+ \\
\hline Viburnum dentatum & VIDE & $4.87 \pm 1.24$ & FAC \\
\hline Viburnum obovatum & VIOB & $4.50 \pm 0.00$ & FACW+ \\
\hline Viburnum rufidulum & VIRU & $6.50 \pm 0.00$ & FACU \\
\hline \multicolumn{4}{|c|}{ Woody Vines } \\
\hline Ampelopsis arborea & AMAR & $3.94 \pm 1.04$ & FAC+ \\
\hline Ampelops is cordata & AMCO & $4.50 \pm 1.41$ & FAC+ \\
\hline Aristolochia tomentosa & ARTO & $6.50 \pm 0.00$ & FAC+ \\
\hline Berchemia scandens & BESC & $4.55 \pm 0.96$ & FACW \\
\hline Bignonia capreolata & $\mathrm{BICA}$ & $5.70 \pm 1.05$ & FAC \\
\hline Brunnichia cirrhosa & BRCI & $3.58 \pm 0.52$ & FACW \\
\hline Campsis radicans & CARA & $4.05 \pm 0.97$ & FAC \\
\hline Cardiospermum halicacabum & CAHA & $2.50 \pm 0.00$ & FAC \\
\hline Clematis Iigusticifolia & CLLI & $6.50 \pm 0.00$ & FACW \\
\hline Cocculus carolinus & COCA & $4.37 \pm 1.01$ & FAC \\
\hline Gelsemium rankinii & GERA & $3.50 \pm 0.00$ & FACW+ \\
\hline Gelsemium sempervirens & GESE & $6.50 \pm 0.00$ & FAC \\
\hline Ipomea lacunosa & IPLA & $2.50 \pm 0.00$ & FAC+ \\
\hline Ipomea wrightii & IPWR & $2.50 \pm 0.00$ & FACW - \\
\hline Lonicera japonica & LOJA & $6.50 \pm 0.00$ & FAC - \\
\hline Lonicera sempervirens & LOSE & $6.50 \pm 0.00$ & FAC \\
\hline Parthenocissus quinquefolia & PAQU & $5.93 \pm 0.79$ & FAC \\
\hline Smilax bona-nox & SMBO & $4.75 \pm 1.30$ & FAC \\
\hline Smilax glauca & SMGL & $5.61 \pm 1.23$ & FAC \\
\hline Smilax hispida & SMHI & $3.80 \pm 0.87$ & FAC+ \\
\hline Smilax laurifolia & SMLA & $4.33 \pm 2.02$ & FACW+ \\
\hline Smilax rotundifolia & SMRO & $5.18 \pm 0.98$ & FAC \\
\hline Smilax walteri & SMWA & $3.05 \pm 0.21$ & OBL \\
\hline
\end{tabular}


Table E-1--continued

\begin{tabular}{|c|c|c|c|}
\hline Species & Species Code & FTI SD & NWI Status \\
\hline Toxicodendron radicans & TORA & $4.82 \pm 0.91$ & FAC \\
\hline Trachelospermum difforme & TRDI & $4.18 \pm 1.14$ & FAC \\
\hline Vitis aestivalis & VIAE & $6.50 \pm 0.00$ & FAC - \\
\hline Vitis cinerea & VICI & $5.50 \pm 1.41$ & FAC+ \\
\hline Vitis palmata & VIPA & $4.07 \pm 0.38$ & FACW - \\
\hline Vitis riparia & VIRI & $4.27 \pm 0.57$ & FACW \\
\hline Vitis rotundifolia & VIRO & $5.71 \pm 0.80$ & FAC \\
\hline Wisteria frutescens & WIFR & $3.65 \pm 0.00$ & FACW \\
\hline
\end{tabular}

Herbs and Woody Seedlings

\begin{tabular}{|c|c|c|c|}
\hline Acalypha gracilems & ACGR & $3.77 \pm 0.00$ & UPL \\
\hline Acalypha rhomboidea & $\mathrm{ACRH}$ & $3.85 \pm 0.47$ & FAC - \\
\hline Acer drummondii & ACDR & $3.64 \pm 0.19$ & OBL \\
\hline Acer negundo & ACNE & $5.58 \pm 0.96$ & FACW \\
\hline Acer rubrum & ACRU & $4.63 \pm 1.10$ & FAC \\
\hline Ageratina altissima & AGAL & $4.71 \pm 1.53$ & FACU - \\
\hline Agrimonia pubescens & AGPU & $6.50 \pm 0.00$ & UPL \\
\hline Agrostis hiemalis & AGHI & $6.50 \pm 0.00$ & FAC \\
\hline Amaranthus rudis & AMRU & $3.50 \pm 0.00$ & FAC \\
\hline Ameranthus tuberculatus & AMTU & $6.50 \pm 0.00$ & FACW+ \\
\hline Ammania coccinea & AMCC & $3.50 \pm 0.00$ & FACW+ \\
\hline Amorpha fruiticosa & AMFR & $3.78 \pm 0.00$ & FACW \\
\hline Ampelamus albidus & AMAL & $6.50 \pm 0.00$ & FAC \\
\hline Ampelopsis arborea & AMAR & $3.76 \pm 0.00$ & FAC+ \\
\hline Ampelopsis brevipedunculata & AMBR & $6.50 \pm 0.00$ & UPL \\
\hline Andropogon virginicus & ANVI & $6.50 \pm 0.00$ & FAC - \\
\hline Aralia spinosa & ARSP & $6.50 \pm 0.00$ & FAC \\
\hline Aristolochia serpentaria & ARSE & $5.07 \pm 1.13$ & \\
\hline Arundinaria gigantea & ARGI & $5.34 \pm 1.42$ & FACW \\
\hline Asarum arifolium & ASAR & $5.50 \pm 0.00$ & FAC - \\
\hline Asclepias perennis & ASPE & $3.24 \pm 0.37$ & OBL \\
\hline Ascyrum hypericoides & ASHY & $6.50 \pm 0.00$ & FAC \\
\hline Aster lateriflorus & ASLA & $4.50 \pm 0.00$ & FAC \\
\hline Aster simplex & ASSI & $3.04 \pm 0.40$ & FACW \\
\hline Berchemia scandens & BESC & $4.72 \pm 1.14$ & FACW \\
\hline Betula nigra & BENI & $4.50 \pm 0.00$ & OBL \\
\hline Bidens cernua & BICE & $3.50 \pm 0.00$ & OBL \\
\hline Bidens discoidea & BIDI & $3.50 \pm 0.00$ & FACW \\
\hline Bidens frondosa & BIFR & $4.17 \pm 0.00$ & FACW \\
\hline Bignonia capreolata & BICA & $5.47 \pm 0.92$ & FAC \\
\hline Boehmeria cylindrica & $\mathrm{BOCY}$ & $3.34 \pm 0.62$ & FACW+ \\
\hline Botrychium biternatum & BOBI & $5.00 \pm 0.71$ & FAC \\
\hline Botrychium virginianum & BOVI & $6.50 \pm 0.00$ & FACU \\
\hline Brunnichia cirrhosa & BRCI & $3.74 \pm 0.62$ & FACW \\
\hline Bumelia lanuginosa & BULA & $6.50 \pm 0.00$ & FACU \\
\hline Callicarpa americana & CAAM & $6.39 \pm 0.22$ & FACU - \\
\hline Campsis radicans & CARA & $4.34 \pm 0.86$ & FAC \\
\hline Cardiospermum halicacabum & CAHA & $3.50 \pm 1.41$ & FAC \\
\hline
\end{tabular}


Table E-1--continued

\begin{tabular}{|c|c|c|c|}
\hline Species & Species Code & FTI SD & NWI Status \\
\hline Carex albolutecens & CAAL & $6.50 \pm 0.00$ & FAC+ \\
\hline Carex blanda & $\mathrm{CABL}$ & $6.50 \pm 0.00$ & FAC - \\
\hline Carex cephalophora & CACE & $6.50 \pm 0.00$ & FAC \\
\hline Carex flaccidula & CAFL & $6.50 \pm 0.00$ & \\
\hline Carex intumescens & CAIN & $4.50 \pm 0.00$ & FACW \\
\hline Carex joorii & CAJO & $4.01 \pm 0.00$ & OBL \\
\hline Carex louisianica & CALO & $4.50 \pm 0.00$ & $\mathrm{OBL}$ \\
\hline Carex squarrosa & CASQ & $4.50 \pm 0.00$ & FACW \\
\hline Carex torta & CATR & $5.83 \pm 0.86$ & OBL \\
\hline Carpinus caroliniana & CACA & $4.84 \pm 0.35$ & FAC \\
\hline Carya aquatica & CAAQ & $3.69 \pm 0.52$ & OBL \\
\hline Carya glabra & CAGL & $6.50 \pm 0.00$ & FACU \\
\hline Carya tomentosa & CATO & $6.50 \pm 0.00$ & UPL \\
\hline Carya illinoensis & CAIL & $6.50 \pm 0.00$ & $\mathrm{FAC}+$ \\
\hline Castanea pumila & CAPU & $6.50 \pm 0.00$ & UPL \\
\hline Celtis laevigata & CELA & $4.77 \pm 0.81$ & FACW \\
\hline Centella erecta & CEER & $3.50 \pm 0.00$ & FACW \\
\hline Cephalanthus occidentalis & CEOC & $3.18 \pm 0.49$ & OBL \\
\hline Cercis canadensis & CECA & $6.50 \pm 0.00$ & FACU \\
\hline Chasmanthium laxum & CHLA & $6.50 \pm 0.00$ & FACW - \\
\hline Chasmanthium sessiliflorum & CHSE & $6.17 \pm 0.82$ & FAC + \\
\hline Chimaphila maculata & CHMA & $6.50 \pm 0.00$ & UPL \\
\hline Chionanthus virginicus & CHVI & $6.50 \pm 0.00$ & FACU \\
\hline Clematis crispa & CLCR & $4.13 \pm 0.48$ & FACW+ \\
\hline Clematis ligusticifolia & CLLI & $6.50 \pm 0.00$ & FACW \\
\hline Clematis viorna & CLVO & $5.50 \pm 0.00$ & UPL \\
\hline Clematis virginiana & CLVI & $4.57 \pm 0.10$ & $\mathrm{FAC}+$ \\
\hline Clethra alnifolia & CLAL & $5.50 \pm 1.41$ & FACW \\
\hline Cnisdoscolus stimulosus & CNST & $6.50 \pm 0.00$ & UPL \\
\hline Cocculus carolinus & COCA & $4.78 \pm 0.90$ & FAC \\
\hline Commelina communis & COCO & $2.50 \pm 0.00$ & FAC \\
\hline Commelina diffusa & CODI & $3.83 \pm 1.53$ & FACW \\
\hline Commelina virginica & COVI & $4.02 \pm 0.06$ & FACW \\
\hline Conoclinium coelestinum & COCE & $6.50 \pm 0.00$ & FAC \\
\hline Cornus drummondi i & CODR & $5.73 \pm 0.00$ & FAC \\
\hline Cornus florida & COFL & $6.50 \pm 0.00$ & FACU \\
\hline Cornus foemina & COFO & $5.25 \pm 0.98$ & FACW- \\
\hline Crataegus aestivalis & CRAE & $3.50 \pm 1.41$ & OBL \\
\hline Crataegus marshallii & CRMA & $6.50 \pm 0.00$ & FAC \\
\hline Crataegus viridis & CRVI & $4.09 \pm 0.77$ & FACW \\
\hline Cynoctonum mitriola & CYMI & $2.56 \pm 0.00$ & FACW - \\
\hline Cyperus erythrorhizos & CYER & $2.50 \pm 0.00$ & OBL \\
\hline Cyrilla racemiflora & CYRA & $3.79 \pm 0.00$ & FACW \\
\hline Decumaria barbara & DEBA & $5.50 \pm 0.00$ & FACW \\
\hline Desmodium glabellum & DEGL & $6.50 \pm 0.00$ & UPL \\
\hline Desmodium paniculatum & DEPA & $6.50 \pm 0.00$ & FACU \\
\hline Desmodium passiflorum & DEPS & $6.50 \pm 0.00$ & UPL \\
\hline Dichanthelium commutatum & DICO & $4.17 \pm 1.36$ & FAC \\
\hline Dichondra carolinensis & DICA & $6.50 \pm 0.00$ & FACW - \\
\hline
\end{tabular}


Table E-1--continued

\begin{tabular}{|c|c|c|c|}
\hline Species & Species Code & FTI SD & NWI Status \\
\hline Dichondra repens & DIRE & $6.50 \pm 0.00$ & FACU \\
\hline Dicliptera brachiata & DIBR & $5.80 \pm 0.00$ & FACW \\
\hline Dioclea multiflora & DIMU & $5.50 \pm 1.41$ & FAC+ \\
\hline Diodia virginiana & DIVR & $3.60 \pm 0.98$ & FACW \\
\hline Dioscorea quaternata & DIQU & $5.50 \pm 1.41$ & FAC \\
\hline Diospyros virginiana & DIVI & $4.59 \pm 0.94$ & FAC \\
\hline Duchesnea indica & DUIN & $5.50 \pm 0.00$ & UPL \\
\hline Echinodorus cordifolius & ECCO & $3.00 \pm 0.70$ & EL \\
\hline Eleocharis microcarpa & ELMI & $2.50 \pm 0.00$ & $\overline{\mathrm{OBL}}$ \\
\hline Elytraria carolinensis & ELCA & $5.00 \pm 0.70$ & FACW \\
\hline Erechtites hieracifolia & ERHI & $3.50 \pm 0.00$ & FAC \\
\hline Erigeron philadelphicus & ERPH & $6.50+0.00$ & FAC \\
\hline Eragrostis hypnoides & ERHY & $2.50 \pm 0.00$ & OBL \\
\hline Eupatorium serotinum & EUSE & $4.17 \pm 1.15$ & FAC \\
\hline Fagus grandifolia & FAGR & $6.50 \pm 0.00$ & FACU \\
\hline Forestiera acuminata & FOAC & $3.32 \pm 0.36$ & FACW+ \\
\hline Fraxinus caroliniana & FRCA & $3.00 \pm 0.45$ & OBL \\
\hline Fraxinus pennyslvanica & FRPE & $4.00 \pm 1.29$ & FACW \\
\hline Galium aparine & GAAP & $6.50 \pm 0.00$ & FACU \\
\hline Galium circaezans & GACI & $6.50 \pm 0.00$ & FACU- \\
\hline Galium trifidum & GATR & $6.50 \pm 0.00$ & UPL \\
\hline Galium uniflorum & GAUN & $6.50 \pm 0.00$ & UPL \\
\hline Gaylussacia frondosa & GAFR & $6.50 \pm 0.00$ & FAC \\
\hline Gelsemium rankinii & GERA & $3.50 \pm 0.00$ & FACW+ \\
\hline Gelsemium sempervirens & GESE & $6.31 \pm 0.38$ & FAC \\
\hline Geum canadense & GECA & $5.32+0.96$ & FAC \\
\hline Gleditsia aquatica & GLAQ & $3.27 \pm 0.00$ & OBL \\
\hline Gratiola virginiana & GRVI & $2.50 \pm 0.00$ & $\mathrm{OBL}$ \\
\hline Hamamelis virginiana & HAVI & $6.50 \pm 0.00$ & FAC \\
\hline Halesia diptera & HADI & $6.50 \pm 0.00$ & FAC \\
\hline Heliotropium indicum & HEIN & $2.50 \pm 0.00$ & $\mathrm{FAC}+$ \\
\hline Hibiscus laevis & HILA & $3.50 \pm 0.00$ & OBL \\
\hline Hypericum galioides & HYGA & $4.53 \pm 0.00$ & $\mathrm{OBL}$ \\
\hline Hypericum hypericoides & HYHY & $5.25 \pm 1.50$ & UPL \\
\hline Hypoxis leptocarpa & HYLE & $3.80 \pm 0.99$ & FACW \\
\hline Hyptis mutabilis & HYMU & $6.50 \pm 0.00$ & FAC \\
\hline Ilex coriacea & ILCO & $5.50 \pm 1.41$ & FACW \\
\hline Ilex decidua & ILDE & $4.46 \pm 0.89$ & FACW- \\
\hline I Iex opaca & ILOP & $6.09+0.51$ & FACU+ \\
\hline Ilex vomitoria & ILVO & $6.50 \pm 0.00$ & FAC \\
\hline Ipomoea lacunosa & IPLA & $3.03 \pm 0.00$ & FAC+ \\
\hline Ipomoea wrightii & IPWR & $2.50 \pm 0.00$ & FACW - \\
\hline Itea virginica & ITVI & $4.03 \pm 0.50$ & FACW + \\
\hline Iva annua & IVAN & $4.50+0.00$ & FAC \\
\hline Juniperus virginiana & JUVI & $6.50 \pm 0.00$ & FACU - \\
\hline Justicia americana & JUAM & $3.83 \pm 0.67$ & $\mathrm{OBL}$ \\
\hline Justicia ovata & JUOV & $6.50 \pm 0.00$ & OBL \\
\hline Lactuca floridana & LAFL & $3.67 \div 0.76$ & FACU \\
\hline Lactuca serriola & LASE & $6.50 \pm 0.00$ & FAC \\
\hline
\end{tabular}


Table E-1--continued

\begin{tabular}{|c|c|c|c|}
\hline Species & Species Code & FTI SD & NWI Status \\
\hline Leersia lenticularis & LELE & $3.65 \pm 0.72$ & OBL \\
\hline Leersia oryzoides & LEOR & $3.50 \pm 0.00$ & OBL \\
\hline Leersia virginica & LEVI & & FACW \\
\hline Leucothoe axillaris & LEAX & $4.50 \pm 0.00$ & FACW \\
\hline Lindera benzoin & LIBE & $6.23 \pm 0.00$ & FACW \\
\hline Lindernia dubia & LIDU & $3.50 \pm 0.00$ & OBL \\
\hline Liquidambar styraciflua & LIST & $4.87 \pm 0.75$ & FAC+ \\
\hline Lonicera japonica & LOJA & $6.50 \pm 0.00$ & FAC - \\
\hline Lonicera sempervirens & LOSE & $6.50 \pm 0.00$ & FAC \\
\hline Ludwigia decurrens & LUDE & $2.50 \pm 0.00$ & OBL \\
\hline Lygodium japonicum & LYJA & $5.17 \pm 0.14$ & FAC \\
\hline Lysimachia radicans & LYRA & $3.86 \pm 0.44$ & OBL \\
\hline Malus coronaria & MACO & $6.50 \pm 0.00$ & UPL \\
\hline Matelea gonocarpa & MAGO & $4.50 \pm 0.00$ & UPL \\
\hline Melia azedarach & MEAZ & $4.50 \pm 0.00$ & UPL \\
\hline Melothria pendula & MEPE & $3.50 \pm 1.41$ & FACW- \\
\hline Mikania scandens & MISC & $4.30 \pm 0.84$ & FACW+ \\
\hline Mimosa strigillosa & MIST & $3.50 \pm 0.00$ & FAC \\
\hline Mitchella repens & MIRE & $5.32 \pm 0.83$ & FACU+ \\
\hline Morus rubra & MORU & $5.70 \pm 0.84$ & FAC \\
\hline Myrica cerifera & MYCE & $6.50 \pm 0.00$ & $\mathrm{FAC}+$ \\
\hline Nyssa aquatica & NYAQ & $2.93 \pm 0.79$ & OBL \\
\hline Nyssa biflora & NYBI & $3.42 \pm 0.12$ & OBL \\
\hline Nyssa ogeche & NYOG & $2.50 \pm 0.00$ & OBL \\
\hline Nyssa sylvatica & NYSY & $4.99 \pm 1.47$ & FAC \\
\hline Onoclea sensibilis & ONSE & $4.62 \pm 1.82$ & FACW \\
\hline Oplismenus hintellus & OPHI & $5.74 \pm 1.00$ & FACU+ \\
\hline Osmunda cinnamomea & OSCI & $4.50 \pm 0.00$ & FACW+ \\
\hline Ostrya virginiana & OSVI & $6.50 \pm 0.00$ & FACU - \\
\hline Oxalis debilis & OXDI & $6.50 \pm 0.00$ & UPL \\
\hline Oxalis stricta & OXST & $5.66 \pm 1.04$ & UPL \\
\hline Panicum rigidulum & PARI & $3.83 \pm 0.45$ & FACW \\
\hline Parietaria pensylvanica & PAPE & $6.50 \pm 0.00$ & FAC - \\
\hline Parthenocissus quinquefolia & PAQU & $5.51 \pm 0.93$ & FAC \\
\hline Paspalum fluitans & PAFL & $2.50 \pm 0.00$ & OBL \\
\hline Paspalum urvillei & PAUR & $2.50 \pm 0.00$ & OBL \\
\hline Passiflora lutea & PALU & $4.50 \pm 0.00$ & UPL \\
\hline Persea borbonia & PEBO & $5.29 \pm 0.00$ & FACW \\
\hline Phanopyrum gymnocarpon & PHGY & $3.00 \pm 0.71$ & OBL \\
\hline Phytolacca americana & PHAM & $6.50 \pm 0.00$ & FACU+ \\
\hline Pilea pumila & PIPU & $3.50 \pm 1.41$ & FACW \\
\hline Pinus glabra & PIGL & $6.29 \pm 0.30$ & FACW \\
\hline Pinus taeda & PITA & $6.50 \pm 0.00$ & FAC \\
\hline Planera aquatica & PLAQ & $3.07 \pm 0.56$ & $\mathrm{OBL}$ \\
\hline Platanthera flava & PLFL & $6.00 \pm 0.71$ & FACW \\
\hline Pluchea camphorata & PLCA & $3.41 \pm 0.13$ & FACW \\
\hline Polygonum hydropiperoides & POHY & $3.50 \pm 1.41$ & OBL \\
\hline Polygonum virginianum & POVI & $5.87 \pm 0.52$ & FAC \\
\hline Polypodium scandens & POSC & $6.50 \pm 0.00$ & UPL \\
\hline
\end{tabular}


Table E-1--continued

\begin{tabular}{|c|c|c|c|}
\hline Species & Species Code & FTI SD & NWI Status \\
\hline Poncirus trifoliata & POTR & $6.50 \pm 0.00$ & UPL \\
\hline Prunus serotina & PRSE & $6.50 \pm 0.00$ & FACU \\
\hline Prunus umbellata & PRUM & $6.50 \pm 0.00$ & UPL \\
\hline Quercus alba & QUAL & $6.50 \pm 0.00$ & FACU \\
\hline $\begin{array}{l}\text { Quercus falcata } \\
\text { var. pagodifolia }\end{array}$ & QUPA & $6.50 \pm 0.00$ & FAC+ \\
\hline Quercus laurifolia & QULA & $3.81 \pm 0.45$ & FACW \\
\hline Quercus lyrata & QULY & $3.80 \pm 1.01$ & OBL \\
\hline Quercus michauxii & QUMI & $5.00 \pm 1.00$ & FACW - \\
\hline Quercus nigra & QUNI & $5.85 \pm 0.70$ & FAC \\
\hline Quercus nuttallii & QUNU & $4.50 \pm 0.00$ & OBL \\
\hline Quercus phellos & QUPH & $5.43 \pm 1.07$ & FACW- \\
\hline Quercus shumardii & QUSH & $5.77 \pm 0.00$ & FACW \\
\hline Quercus stellata & QUST & $6.50 \pm 0.00$ & FACU \\
\hline Quercus velutina & QUVE & $6.50 \pm 0.00$ & UPL \\
\hline Quercus virginiana & QUVI & $6.50 \pm 0.00$ & FACU+ \\
\hline Rhododendron canescens & $\mathrm{RHCN}$ & $6.50 \pm 0.00$ & FACW \\
\hline Rhus copallinum & RHCO & $6.50 \pm 0.00$ & \\
\hline Ricciocarpus natans & RINA & $2.50 \pm 0.00$ & OBL \\
\hline Robinia nana & RONA & $6.50 \pm 0.00$ & UPL \\
\hline Robinia psuedoacacia & ROPS & $6.50 \pm 0.00$ & UPL \\
\hline Rorippa islandica & ROIS & $2.50 \pm 0.00$ & OBL \\
\hline Rubus argutus & RUAR & $6.17 \pm 0.58$ & FACUt \\
\hline Rubus occidentalis & RUOC & $6.50 \pm 0.00$ & UPL \\
\hline Rubus trivialis & RUTR & $5.20 \pm 0.80$ & FACU+ \\
\hline Sabatia calycina & SACA & $5.00 \pm 2.12$ & OBL \\
\hline Sabal minor & SAMI & $5.01 \pm 0.77$ & FACW \\
\hline Salix nigra & SANI & $2.50 \pm 0.00$ & OBL \\
\hline Sambucus canadensis & SACA & $5.85 \pm 0.94$ & FACW- \\
\hline Sanicula canadensis & SACN & $6.39 \pm 0.00$ & FACU \\
\hline Sassafras albidum & SAAL & $6.07 \pm 1.13$ & FACU \\
\hline Saururus cernuus & SACE & $3.65 \pm 0.45$ & OBL \\
\hline Scleria triglomerata & SCTR & $6.50 \pm 0.00$ & FACU+ \\
\hline Sebatia calycina & SECA & $5.50 \pm 0.00$ & \\
\hline Sebastinania fruticosa & SEFR & $5.26 \pm 1.16$ & FACW \\
\hline Senecio glabellus & SEGL & $4.36 \pm 0.00$ & FACW+ \\
\hline Sesbania exaltata & SEEX & $2.50 \pm 0.00$ & FACW- \\
\hline Smallanthus uvedalia & SMUV & $6.50 \pm 0.00$ & \\
\hline Smilax bona-nox & SMBO & $5.32 \pm 0.94$ & FAC \\
\hline Smilax glauca & SMGL & $5.62 \pm 0.95$ & UPL \\
\hline Smilax hispida & SMHI & $3.95 \pm 0.95$ & FAC + \\
\hline Smilax laurifolia & SMLA & $3.50 \pm 0.00$ & FACW+ \\
\hline Smilax pumila & SMPU & $6.50 \pm 0.00$ & UPL \\
\hline Smilax rotundifolia & SMRO & $5.06 \pm 0.89$ & FAC \\
\hline Smilax walteri & SMWA & $4.11 \pm 0.13$ & OBL \\
\hline Solanum carolinense & SOCA & $5.50 \pm 1.41$ & FACU \\
\hline Solidago altissima & SOAL & $5.50 \pm 0.00$ & FACU+ \\
\hline Solidago odorata & SOOD & $6.50 \pm 0.00$ & UPL \\
\hline Spermacoce glabra & SPGL & $3.50 \pm 1.00$ & FACWD \\
\hline
\end{tabular}


Table E-1--continued

\begin{tabular}{|c|c|c|c|}
\hline Species & Species Code & FTI SD & NWI Status \\
\hline Spilanthes americana & SPAM & $3.00 \pm 0.71$ & FACW \\
\hline Stylisma humistrata & STHU & $6.50 \pm 0.00$ & UPL \\
\hline Styrax americana & STAM & $3.29 \pm 0.86$ & FACW \\
\hline Symplocos tinctoria & SYTI & $6.18 \pm 0.46$ & FAC \\
\hline Taxodium distichum & TADI & $3.09 \pm 0.66$ & OBL \\
\hline Thelypterus kunthii & THKU & $5.50 \pm 0.00$ & FACW \\
\hline Toxicodendron radicans & TORA & $4.94 \pm 0.71$ & \\
\hline Trachelospermum difforme & TRDI & $4.26 \pm 0.85$ & FAC \\
\hline Triadinum walteri & TRWA & $3.50 \pm 1.41$ & OBL \\
\hline Tragia urens & TRUR & $6.50 \pm 0.00$ & \\
\hline Trepocarpus aethusae & TRAE & $6.50 \pm 0.00$ & FACW \\
\hline Ulmus alata & ULAL & $5.66 \pm 0.84$ & FACU+ \\
\hline Ulmus americana & ULAM & $4.35 \pm 0.59$ & FACW \\
\hline Ulmus rubra & ULRU & $6.50 \pm 0.00$ & FAC \\
\hline Urtica chamaedryoides & URCH & $4.42 \pm 0.00$ & FAC \\
\hline Vaccinium arboreum & VAAR & $6.50 \pm 0.00$ & FACU \\
\hline Vaccinium corymbosum & VACO & $4.50 \pm 0.00$ & FACW \\
\hline Vaccinium elliottii & VAEL & $6.06 \pm 0.53$ & FAC+ \\
\hline Vernonia gigantea & VEGI & $4.75 \pm 0.00$ & FAC+ \\
\hline Viburnum dentatum & VIDE & $6.05 \pm 0.78$ & FAC \\
\hline Viburnum cassinoides & VICA & $6.50 \pm 0.00$ & FACW \\
\hline Viburnum obovatum & VIOB & $6.50 \pm 0.00$ & FACW+ \\
\hline Viburnum rufidulum & VIRU & $6.50 \pm 0.00$ & FACU \\
\hline Viola floridana & VIFL & $5.69 \pm 0.45$ & FACW - \\
\hline Viola missouriensis & VIMI & $4.83 \pm 0.58$ & FAC+ \\
\hline Viola papilionacea & VIPA & $3.58 \pm 0.75$ & FAC \\
\hline Viola triloba & VITR & $6.50 \pm 0.00$ & UPL \\
\hline Vitis aestivalis & VIAE & $6.50 \pm 0.00$ & FAC - \\
\hline Vitis cinerea & VICI & $3.50 \pm 0.00$ & FAC+ \\
\hline Vitis palmata & VIPA & $3.58 \pm 0.75$ & FACW \\
\hline Vitis riparia & VIRI & $4.37 \pm 1.06$ & FACW \\
\hline Vitis rotundifolia & VIRO & $5.89 \pm 0.68$ & FAC \\
\hline Vitis vulpina & VIVU & $3.53 \pm 0.00$ & FAC+ \\
\hline Woodwardia areolata & WOAR & $4.50 \pm 0.00$ & OBL \\
\hline Woodwardia virginica & WOVI & $3.97 \pm 0.00$ & OBL \\
\hline
\end{tabular}




\section{Definitions for Waterlogging Tolerance Rating}

Most Tolerant. Those species that are capable of living from seedling to maturity in soils that are waterlogged almost continually year after year except for short durations during droughts. The soils are typically anaerobic in character but are less so where the water is moving. Some species in this group adapt by producing soil water roots that oxidize their rhizosphere, accelerate anaerobic metabolism but at a controlled rate and tolerate the toxic compounds typical of highly reduced waterlogging soils.

Highly Tolerant. Those species capable of living from seedling to maturity in soils that are waterlogged for 50 to 75 percent of the year. Waterlogging typically occurs during the winter, spring and 1-3 months of summer.

Moderately Tolerant. Those species capable of living from seedling to maturity in soils waterlogged about 50 percent of the time. Waterlogging typically occurs in portions of the winter, spring, and early summer.

Weakly Tolerant. Those species that are capable of 1 iving from seedling through maturity in soils that are temporarily waterlogged for durations of $1-4$ weeks and usually accounting for 10 percent of the growing season.

Least Tolerant. Those species that are capable of living from seedling through maturity in soils that are occasionally waterlogged for durations of a few days only, usually accounting for less than 2 percent of the growing season.

\section{Definitions for NWI Status Descriptions}

Obligate Wetland (OBL). Occur almost always (estimated probability $>99$ percent) under natural conditions in wetlands.

Facultative Wetland (FACW). Usually occur in wetlands (estimated probability 67 to 99 percent), but occasionally found in nonwetlands.

Facultative (FAC). Equally likely to occur in wetlands or nonwetlands (estimated probability 34 to 66 percent).

Facultative Upland (FACU). Usually occur in nonwetlands (estimated probability 67 to 99 percent), but occasionally found in wetlands (estimated probability 1 to 33 percent).

Obligate Upland (UPL). Occur in wetlands in another region, but occur almost always (estimated probability $>99$ percent) under natural conditions in nonwetlands in the region specified. If a species does not occur in wetlands in any region, it is not on the National List.

A positive (+) or negative (-) symbol was used with the Facultative Indicator categories to define more specifically the regional 
frequency of occurrence in wetlands. The positive sign indicates a frequency toward the higher end of the category (more frequently found in wetlands), and a negative sign indicates a frequency toward the lower end of the category (less frequently found in wetlands). 


\section{REFERENCES}

Bailey, R. G. Description of the ecoregions of the United States. 1980; Washington, DC: U.S. Department of Agriculture, Miscellaneous Publication No. 1391, 77 p.

Bedinger, M. S. Forest species as indicators of flooding in the Lower White River Valley, Arkansas. Geological Survey Research, U.S. Geological Survey Professional Paper 750-C; 1971; C248-C253.

Bedinger, M. S. Relation between forest species and flooding. Greeson, P. E.; Clark, J. R.; Clark, J. E., eds. Wetland functions and values: the state of our understanding; proceedings of the national symposium on wetlands. Minneapolis: American Water Resources Association; 1978; $427-435$.

Best, R. G.; Segal, D. S.; and Wolfe, C. Soil-vegetation correlations in selected wetlands and uplands of north-central Florida. 1990; $48 \mathrm{p}$. Biological Report 90(9).

Bray, J. R. A study of natural occurrence of plant species. Ecology $37: 21-28 ; 1956$.

Brinson, M. M. Riverine forests. Lugo, A. E.; Brinson, M.; Brown, S., eds. Ecosystems of the world; Vol 15, Forested wetlands. New York: Elsevier; $1990 ; 87-141$.

Broadfoot, W. M.; Williston, H. L. Flooding effects on southern forests. J. For. 71:584-587; 1973 .

Brown, R. T.; Curtis, J. T. The upland conifer-hardwood forests of northern Wisconsin. Ecol. Monogr. 22:217-234; 1952.

Brown, S. A comparison of the structure, primary productivity, and transpiration of cypress ecosystems in Florida. Ecol. Monogr.

$51(4): 403-427 ; 1981$.

Bruckner, W.; Bowersox, T.W.; Ward, W. W. Response of trees to flooding at the Curwensille Reservoir. University Park, PA: Pennsylvania State University; $1973 ; 4 \mathrm{pp}$.

Cannon, W. A.; Free, E. E. Root adaptation to deficient soil aeration. Yearbook Vol 19. Washington, DC: Carnegie Institution of Washington; $1920 ; 62$. 
Chambless, L. F.; Nixon, E. S. Woody vegetation-soil relations in a bottomland forest of east Texas. Texas Journal of Science XXVI $(3,4)$ : $407-416 ; 1975$.

Clark, J. R.; Benforado, J., eds. Wetlands of bottomland hardwood forests. New York: Elsevier; 1981.

Clements, F. E. Plant succession. Washington, DC: Carnegie Institution of Washington; 1916. Publication 242.

Conway, V. M. Aeration and plant growth in wet soils. Bot. Rev. $6: 149-163 ; 1940$.

Curtis, J. T. The vegetation of Wisconsin: An ordination of plant communities. Madison, WI: University of Wisconsin Press; 1959.

Curtis, J. T.; McIntosh, R. P. An upland forest continuum in the prairie-forest border region of Wisconsin. Ecology 32:476-496; 1951.

Daubenmire, R. Plant communities; a textbook of plant synecology. New York: Harper \& Row; 1968.

Dickson, R. E.; Hosner, J. F.; Hosley, N. W. The effects of four water regimes upon the growth of four bottomland tree species. For. Sci. $11: 299-305 ; 1965$.

Dubinina, J. M. Metabolism of roots under various conditions of aeration. Soviet Plant Physiology 8:314-322; 1961.

Faulkner, S. P.; Patrick, W. H., Jr.; Parker, W. B.; Gambrell, R. P.; Good, B. J. Characterization of soil processes in bottomland hardwood wetland-nonwetland transition zones in the lower Mississippi River Valley. Vicksburg, MS: U.S. Army Engineer Waterways Experiment Station; 1991. Contract report WRP-91-1.

Gleason, H. A. The structure and development of the plant association. Torrey Bot. Club Bull. 44:463-481; 1917.

Grubb, P. J. The maintenance of species-richness in plant communities: the importance of the regeneration niche. Bibl. Rev. 52:107-145; 1977.

Hal1, T. F.; Smith, G. E. Effects of flooding on woody plants, West Sandy Dewatering Project, Kentucky Reservoir. J. For. 53:281-285; 1955.

Hodges, J. D.; Switzer, G. L. Some aspects of the ecology of southern bottomland hardwoods. Stoneville, MS: Mississippi Agricultural and Forestry Experiment Station; 1979. Journal paper 4087; 360-365.

Hook, D. D.; Brown, C. L. Root adaptations and relative flood tolerance of five hardwood species. For. Sci. 19:225-229; 1973.

Hook, D. D.; Crawford, R. M. M., eds. Plant life in anaerobic environments. Ann Arbor, MI: Ann Arbor Science Publishers; 1980. 
Hook, D. D. ; McKee, W. H., Jr.; Smith, H. K.; Gregory, J.; Burre11, V. G., Jr.; DeVoe, M. R.; Sojka, R. E.; Gilbert, S.; Banks, R.; Stolzy, L. H. ; Brooks, C.; Matthews, T. D.; Shear, T. H., eds. The ecology and management of wetlands. Portland, OR: Timber Press; 1988.

Hook, D. D.; Scholtens, J. R. Adaptations and flood tolerance of tree species. Hook, D. D.; Crawford, R. M. M., eds. Plant life in anaerobic environments. Ann Arbor, MI: Ann Arbor Science Series Inc.; 1978: $299-311$.

Hook, D. H. Waterlogging tolerance of lowland tree species of the south. South. J. Appl. Forest. 8(3):136-49; 1984.

Hosner, J. F.; Boyce, S. G. Tolerance to water saturated soil of various bottomland hardwoods. For. Sci. 8:180-186; 1962.

Huenneke, L. F.; Sharitz, R. R. Microsite abundance and distribution of woody seedlings in a South Carolina cypress-tupelo swamp. American Midland Naturalist $115(2): 328-335 ; 1986$.

Huffman, R. T. The relationship of flood timing and duration to variation in selected bottomland hardwood communities of southern Arkansas. Vicksburg, MS: U.S. Army Engineer Waterways Experiment Station; 1980. Miscellaneous Paper EL-80-4.

Hupp, C. R.; Osterkamp, W. R. Bottomland vegetation distribution along Passage Creek, Virginia, in relation to fluvial landforms. Ecological Society of America 66(3):670-681; 1985.

Kangas, P. C. An energy theory of landscape for classifying wetlands. Lugo, A. E.; Brinson, M.; Brown, S., eds., Ecosystems of the world; Vo1 15, Forested Wetlands. New York: Elsevier; 1990; 15-23.

Larson, J. S.; Bedinger, M. S.; Bryan, C. F.; Brown, S.; Huffman, R. T.; Miller, E. L.; Rhodes, D. G.; Touchet, B. A. Transition from wetlands to uplands in southeastern bottomland hardwood forests. Clark, J. R.; Benforado, J., eds. Wetlands of bottomland hardwood forests. New York: Elsevier; 1981:225-273.

Leitman, H. M.; Sohm, J. E.; Franklin, M. A. Wetland hydrology and tree distribution of the Apalachicola River flood plain, Florida. Washington, D.C.: U.S. Geological Survey; 1984. Water-supply paper 2196-A.

McIntosh, R. P. The background and some current problems of the theoretical ecology, Synthese 43:195-255; 1980.

Mitsch, W. J.; Gosselink, J. G. Wetlands. New York: Van Nostrand Reinhold; 1986.

Mohler, C. L. An analysis of floodplain vegetation of the lower Neches drainage, southwest Texas, with some considerations on the use of regression and correlation in plant synecology. Ithaca, NY: Cornell University; 1979. 658 p. Dissertation, Dissertation Abstracts International No. 792633 . 
Patrick, W. H., Jr.; Delaune, R. D. Nitrogen and phosphorus utilization by Spartina alterniflora in a salt marsh in Barataria Bay, Louisiana: estuarine, Coast. Mar. Sci. 4:59-64; 1976.

Patrick, W. H., Jr.; Mikkelsen, D. S. Plant nutrient behavior in flooded soil. Fertilizer technology and use, 2d ed. Madison, WI: Soil Science Society of America; 1971.

Pearsal1, W. H.; Mortimer, C. H. Oxidation and reduction potentials in waterlogged soils, natural waters and muds. J. Ecol. 27:483-501; 1939.

Ponnamperuma, F. N. The chemistry of submerged soils. Adv. Agron. 24:29-96; 1972 .

Putnam, J. A.; Furnival, G. M.; McKnight, J. S. Management and inventory of southern hardwoods. Washington, DC: U.S. Department of Agriculture, Forest Service Agricultural Handbook 181:3-7; 1960.

Reed, P. B., Jr. Wetland plants of the United States of America 1988, St. Petersburg, FL: U.S. Fish and Wildlife Service; 1988. WELUT$88 / \mathrm{W} 17.01$.

Roelle, J. E. ; Auble, G. T.; Hamilton, D. B. ; Johnson, R. L. ; Segelquist, C. A., eds. Results of a workshop concerning ecological zonation in bottomland hardwoods. Ft. Collins, CO: U.S. Fish and Wildlife Service, National Ecology Center; 1987; NEC-87/14.

Ter Braak, C. J. F.; Prentice, I. C. A theory of gradient analysis. Advances in Ecological Research 18:271-313; 1988.

U.S. Department of Agriculture. National list of scientific plant names, vols I and II. Washington, DC: Soil Conservation Service; 1982. SCS - TP- 159 .

Van Der Valk, A. G. Succession in wetlands; a Gleasonian approach. Ecology $62(3): 688-696 ; 1981$.

Vester, G. The physiology of flooding tolerances in trees. Bot. Sci. Edinb. Trans. 41(4):556-557; 1972 .

Whittaker, R. H. Vegetation of the Great Smoky Mountains. Ecol. Monogr. 26:1-69; 1956.

Whittaker, R. H. Gradient analysis of vegetation. Biol. Rev. 49:207-264; 1967 .

Whittaker, R. H. Direct gradient analysis: techniques. Whittaker, R. H., ed. Ordination and classification of communities. The Hague: Junk; Handbook of vegegation science 5:7-31; 1973 .

Whittaker, R. H. Ordination of plant communities, the Hague; 1978; $388 \mathrm{p}$. 
Whittaker, R. H.; Niering, W. A. Vegetation of the Santa Catalina Mountains, Arizona: a gradient analysis of the south slope. Ecology 46:429-452; 1965 . 


\section{BIOGRAPHICAL SKETCH}

Russell Francis Theriot was born January 15, 1947, in Crowley, Louisiana. He is married to the former Patricia Anne Bales; they have two children, Sheri and Craig.

As an undergraduate, he attended Louisiana State University and the University of Southwestern Louisiana. He served three years in the United States Army and then returned to his undergraduate studies in 1969 at Northwestern State University in Louisiana. He received his Bachelor of Science degree in Wildlife Management and his Master of Science degree in Botany at Northwestern State University in 1972 and 1974, respectively.

Upon graduating with his Master's degree, he worked for two years in the Florida Department of Natural Resources as an environmental specialist. Since 1976, he has been employed at the U.S. Army Engineer Waterways Experiment Station in Vicksburg, Mississippi, where he presently serves as Director of the Wetlands Research and Technology Center.

He is a member of Beta Beta Beta, the Ecological Society of America, and the Society of Wetland Scientists. He is also a member of several national committees, including the National Technical Committee for Hydric Soils, the National Review Panel of Plant Species that Occur in Wetlands, the Interagency Committee Developing the National Wetlands 
Delineation Manual, and the Wetlands Research Subcommittee of the Committee on Earth and Environmental Sciences. 
I certify that I have read this study and that in my opinion it conforms to acceptable standards of scholarly presentation and is fully adequate, in scope and quality, as a dissertation for the degree of Doctor of Philosophy.

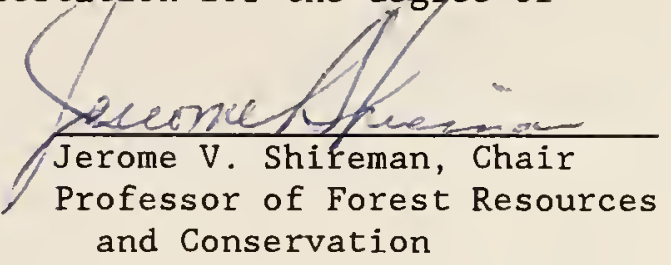

I certify that I have read this study and that in my opinion it conforms to acceptable standards of scholarly presentation and is fully adequate, in scope and quality, as a dissertation for the degree of Doctor of Philosophy.

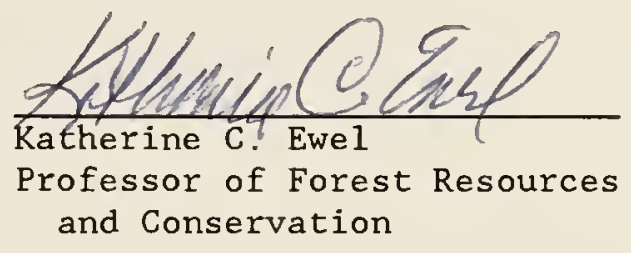

I certify that I have read this study and that in my opinion it conforms to acceptable standards of scholarly presentation and is fully adequate, in scope and quality, as a dissertation for the degree of Doctor of Philosophy.

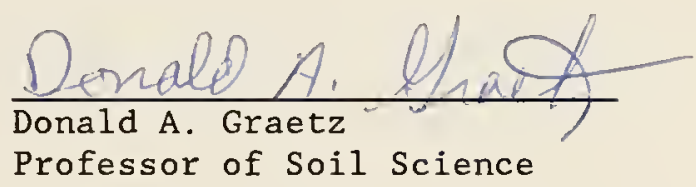

I certify that I have read this study and that in my opinion it conforms to acceptable standards of scholarly presentation and is fully adequate, in scope and quality, as a dissertation for the degree of Doctor of Philosophy.

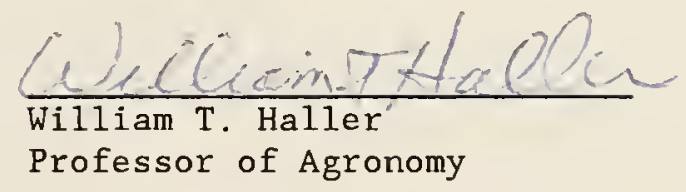

I certify that I have read this study and that in my opinion it conforms to acceptable standards of scholarly presentation and is fully adequate, in scope and quality, as a dissertation for the degree of Doctor of Philosophy.
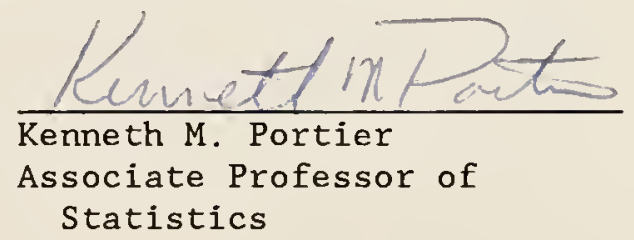
This dissertation was submitted to the Graduate Faculty of the School of Forest Resources and Conservation in the College of Agriculture and to the Graduate School and was accepted as partial fulfillment of the requirements for the degree of Doctor of Philosophy.

May 1992

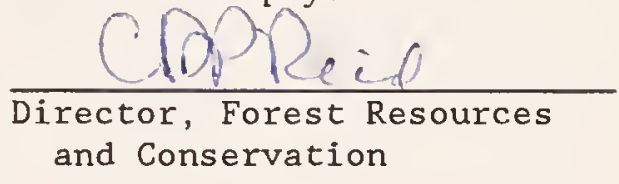

Dean, Graduate School 
UNIVERSITY OF FLORIDA

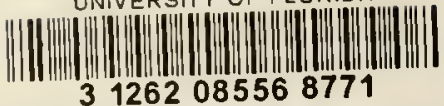

